\title{
Effect of Composted and Vermicomposted Cotton Residues on Nutrient Contents, Ryegrass Growth and Bacterial Blight Mitigation
}

\begin{abstract}
A Dissertation Submitted in Partial Fulfillment of the Requirements to Obtain the Academic Degree of Doctor of Philosophy $(\mathrm{PhD})$ in the International Ph. D. Program for Agricultural Sciences in Göttingen (IPAG) at the Faculty of Agricultural Sciences of the Georg-August-University Göttingen, Germany
\end{abstract}

\author{
Presented by \\ Sulieman Hammad Nasser Ali \\ Born in Kassala, Sudan \\ Supervisors \\ Prof. Dr. Yakov Kuzyakov \\ Prof. Dr. Rainer Georg Jörgensen
}

Göttingen, September 2011 
D7 (this is the number of our faculty it's important for the university library)

1. Name of supervisor: Prof. Dr. Yakov Kuzyakov

2. Name of co-supervisor: Prof. Dr. Rainer Georg Jörgensen

Date of dissertation: November 2011. 


\section{Summary}

The use of organic residues as amendments to improve soil organic matter level and long term soil fertility is gaining importance due to their potential for improving soil health and productivity. Conversion of crop residues in order to ameliorate soil characteristics depends on their quality and maturity, which in turn depends upon the composition of the initial materials. In developing countries, most crop residues are used as animal feed, housing materials and fuel woods or burnt to ease the preparation for the next crop or for disease and insect control. As has been repeatedly pointed out, burning needs to be discouraged, because it destroys a major part of organic matter with a simultaneous loss of the volatile elements such as nitrogen and sulfur, and should be avoided unless absolutely necessary for pest control. In the Sudan agricultural residues are wasted annually at the end of each growing season; cotton residues in particular are annually burnt in order to prevent the spread of bacterial blight which causes $35 \%$ losses of productivity of the following season.

This study was done in two parts; laboratory and green house experiment which was implemented in the Department of Crop Sciences, University of Goettingen, Germany, and the second part was in the Faculty of Agriculture, University of Khartoum, Sudan. Different experiments were carried out; evaluation of the decomposition of cotton residues under composting and vermicomposting and phytoxicity bioassay test to evaluate finished compost and vermicompost suitability for agricultural applications was also conducted. Results of these experiments led to a pot trial to investigate ryegrass nutrients uptake. Simultaneously, a nitrogen incubation experiment was conducted to evaluate the rate of the mineralized nitrogen from compost and vermicompost. In attempts to find an alternative to the burning of cotton residues, an experiment was conducted to study the efficacy of composting and vermicomposting to lessen the colony forming units of the cotton bacterial blight.

For this work, cotton residues were collected from farms located in El-Gazira Irrigated Farming Systems (El-Gazira State, Sudan) while soil samples were collected from the surface $(0-30 \mathrm{~cm})$ of Shambat soil. The farm yard manure $(\mathrm{FYM})$ was gathered from a farm near the Faculty of Agriculture- University of Khartoum, Shambat, Sudan, for the 
work carried out in Sudan; and from the Institute of Animal Husbandry, University of Goettingen, Germany, for the experiment conducted in Germany.

Periodic samples analysis was carried out where total carbon and total nitrogen were determined by dry combustion on an elemental analyzer, while ammonium and nitrate concentrations were conducted on fresh samples using micro-Kjeldahl distillation methods and the mineral nitrogen was calculated as addition of ammonium and nitrate. Phosphorus was analyzed following the molybdate blue complex method and then measured spectrophotometrically. While the electrical conductivity and $\mathrm{pH}$ were determined in a suspension of 1:10 (w/v) compost: water ratio. Some macro and micro nutrients were measured according to a method using pressure digestion system.

Different studies have been conducted in University of Goettingen, Germany. The first study characterized the composted and vermicomposted cotton residues for their chemical composition and agronomic value and aimed to (1) monitor chemical changes during composting and vermicomposting of cotton residues, (2) to elaborate and correlate the results of the chemical changes with the data of the bioassays performed on plants and (3) to determine quality parameters that best describe finished composts and vermicomposts.

The results of this part showed that analyses of the compost and vermicompost have shown a broad variation in $\mathrm{pH}$, total $\mathrm{N}$, total $\mathrm{C}, \mathrm{C}: \mathrm{N}$ ratio, $\mathrm{EC}$, and mineral contents. The finished compost and vermicompost values of the C:N (15.4 and 15.2 for compost and vermicompost, respectively), $\mathrm{pH}$ (6.6 for compost and 7.9 for vermicompost) and EC (2.96 dS m $\mathrm{m}^{-1}$ and $1.62 \mathrm{dS} \mathrm{m}^{-1}$ for compost and vermicompost, respectively) are within the common ranges advised for the mature materials (C:N 15-20; $\mathrm{pH} 5.5-8.0$; EC $4 \mathrm{dS} \mathrm{m}^{-1}$ ) except for the value $\mathrm{NH}_{4}-\mathrm{N}: \mathrm{NO}_{3}-\mathrm{N}$ (1.57) of the finished compost which is far above the advised value (0.16) while the value of the finished vermicompost (0.1) is below the threshold value.

A correlation between $\mathrm{NH}_{4}-\mathrm{N}, \mathrm{NO}_{3}-\mathrm{N}, \mathrm{EC}, \mathrm{C}: \mathrm{N}$, and $\mathrm{pH}$ were conducted. For vermicompost, the correlation coefficients between $\mathrm{C}: \mathrm{N}$ ratio and $\mathrm{NH}_{4}-\mathrm{N}, \mathrm{NO}_{3}-\mathrm{N}, \mathrm{pH}$ and EC were $r=0.86(P<0.01),-0.79(P<0.01), 0.91(P<0.01)$ and $-0.77(P<0.01)$, 
respectively. Ammonium-N concentration was well correlated to $\mathrm{NO}_{3}-\mathrm{N}(r=-0.95, P$ $<0.01$ ). The negative correlation between $\mathrm{NH}_{4}-\mathrm{N}$ and $\mathrm{NO}_{3}-\mathrm{N}$ indicated that material underwent active biological decomposition; this result was supported with the value of $\mathrm{NH}_{4}-\mathrm{N}: \mathrm{NO}_{3}-\mathrm{N}$ ratio. The significant negative correlation between $\mathrm{C}: \mathrm{N}$ ratio and $\mathrm{NO}_{3}-\mathrm{N}$ ( $r=-0.79, P<0.01)$ and $\mathrm{C}: \mathrm{N}$ and $\mathrm{NH}_{4}-\mathrm{N}$ mirrored the trend of vermicomposting. For the compost; the correlation coefficients between $\mathrm{C}: \mathrm{N}$ ratio and $\mathrm{NH}_{4}-\mathrm{N}, \mathrm{NO}_{3}-\mathrm{N}, \mathrm{pH}$ and $\mathrm{EC}$ were $r=0.88(P<0.01), 0.94(P<0.01), 0.59(P=0.02)$ and $-0.72(P<0.01)$, respectively. Ammonium-N concentration was also well correlated with $\mathrm{NO}_{3}-\mathrm{N}(r=0.80, P<0.01)$. This study further suggested that the reduction in $\mathrm{C}: \mathrm{N}$ ratio with time can be taken as a reliable parameter to mirror the progress in decomposition especially when combined with $\mathrm{NH}_{4}-\mathrm{N}, \mathrm{NO}_{3}-\mathrm{N}, \mathrm{pH}$, and $\mathrm{EC}$ for vermicompost and with $\mathrm{NH}_{4}-\mathrm{N}, \mathrm{pH}$, and $\mathrm{EC}$ for compost.

Organic materials may exert harmful effect on plants or germinating seeds, therefore, phytotoxicity bioassay test as an important indicator of their quality was conducted aiming at evaluating the toxicity and suitability of the finished composts and vermicomposts from cotton residues on the germination of cress seed. The effects of water extracts of different substrates were investigated where germinated seeds were counted and primary root length of cress (Lepidium sativum L.) was measured. Germination indexes obtained for vermicompost $(>80 \%)$ are greater than the values advised for the mature compost $(>70 \%)$ while compost $(>50 \%)$ did not attain it. Results of this work showed that finished vermicompost performed best in cress bioassay and could be considered mature while compost did show adverse effects on seed germination and may need more time to be processed.

The evaluation of the finished compost and vermicompost facilitated its application as a constituent of pot materials for the ryegrass growth. A simultaneous nitrogen mineralization incubation experiment under laboratory conditions was conducted in order to evaluate compost and vermicompost $\mathrm{N}$ release and also to predict the long term effect of their application. Both parts aimed at determining the performance of compost and vermicompost for plant growth after single application, testing the reliability of the $\mathrm{N}$ fate predicted by incubation experiment, and assessing potentially mineralizable nitrogen 
from compost and vermicompost. In order to reach those aims, a pot experiment was conducted in a greenhouse at the Department of Crop Sciences - Georg-August University, Göttingen under natural lighting and ambient temperature. Compost and vermicompost corresponded to 4 and $8 \mathrm{~g} \mathrm{~N}$ pot $^{-1}$ were used, respectively. Finished compost and vermicompost used in the pot experiment have been incubated to study the $\mathrm{N}$ mineralization.

Data from the pot experiment showed that, for both rates of compost and vermicompost, biomass yields declined sharply after the second harvest and the significant differences $(P<0.05)$ was only calculated for the first, second, and the last harvests. The biomass of the first and the last harvests of the pots amended with vermicompost corresponded to $4 \mathrm{~g}$ $\mathrm{N}_{\text {pot }}{ }^{-1}$ (VER1) were 1.4 and $0.1 \mathrm{~g} \mathrm{~kg}^{-1}$, respectively, while the ryegrass biomass sown on pots amended with vermicompost corresponded to $8 \mathrm{~g} \mathrm{~N}$ pot $^{-1}$ (VER2) were $0.8 \mathrm{~g} \mathrm{~kg}^{-1}$ for the first harvest and $0.2 \mathrm{~g} \mathrm{~kg}^{-1}$ for the last one. While the results from pots amended with compost corresponded to $4 \mathrm{~g} \mathrm{~N}$ pot $^{-1}(\mathrm{CPF} 1)$ were 1.8 and $0.1 \mathrm{~g} \mathrm{~kg}^{-1}$, respectively, ryegrass biomass sown on pots amended with compost corresponded to $8 \mathrm{~g} \mathrm{~N}^{\mathrm{N}} \mathrm{pot}^{-1}$ (CPF2) were $1.4 \mathrm{~g} \mathrm{~kg}^{-1}$ for the first harvest and $0.3 \mathrm{~g} \mathrm{~kg}^{-1}$ for the last one. Observed reduction in biomass in all pots amended with compost or vermicompost at 30 days onwards, seems to be the result of an extreme shortage of available $\mathrm{N}$ to the ryegrass especially for pots amended with vermicompost. This suggestion was pronounced in the vermicompost and was further supported by the visual signs of $\mathrm{N}$ deficiency (chlorosis).

Results also showed that for both compost and vermicompost amended pots, total $\mathrm{N}$ of ryegrass followed the trend observed in the biomass where the higher $\mathrm{N}$ content was observed at the first harvest and the lowest at the last one. The ranges of $\mathrm{N}$ content of the compost rates were $6.1-6.4 \%$ and $2.4-2.9 \%$ for harvest at 10 days and 70 days, respectively. While the ranges of the vermicomposted amended pots were $3.7-4.0 \%$ for the harvest at 10 days and $1.9-2.1 \%$ for the harvest at 70 days. For most of the harvests, the $\mathrm{N}$ content of ryegrass grown on pots amended with compost are within the sufficiency levels (3-4.2\%) of $\mathrm{N}$ for the normal growth while the only values of the vermicompost amended pots that felt within this range were confined to harvest at 10, 60 and 70 days. 
However, the efficiency of crop $\mathrm{N}$ uptake was low (> $80 \%$ of $\mathrm{N}$ was not utilized by the crop).

Results of the $\mathrm{N}$ incubation experiment showed that maximum and minimum values of total mineral $\mathrm{N}$ varied between the compost and vermicompost application rates. Accordingly, values were found to range from 9.41 to $44.0 \mathrm{mg} \mathrm{N} \mathrm{kg} \mathrm{N}^{-1}$ for the vermicompost corresponding to $4 \mathrm{~g} \mathrm{~N}^{-1}$ (VER1), 13.2 to $51.0 \mathrm{mg} \mathrm{N} \mathrm{kg}{ }^{-1}$ for vermicompost corresponding to $8 \mathrm{~g} \mathrm{~N}^{-1}$ (VER2), 7.2 to $27.4 \mathrm{mg} \mathrm{N} \mathrm{kg}^{-1}$ for compost corresponding to $4 \mathrm{~g} \mathrm{~N}^{-1}$ (CPF1), and 4.2 to $46.0 \mathrm{mg} \mathrm{N} \mathrm{kg}{ }^{-1}$ for compost corresponding to $8 \mathrm{~g} \mathrm{~N}^{-1} \operatorname{pot}^{-1}(\mathrm{CPF} 2)$.

Net $\mathrm{N}$ mineralization at the end of the incubation period was significantly $(P<0.001)$ different between compost and vermicompost and their application rates. Soils amended with vermicompost corresponding to $4 \mathrm{~g} \mathrm{~N} \operatorname{pot}^{-1}$ (VER1), vermicompost corresponding to $8 \mathrm{~g} \mathrm{~N} \operatorname{pot}^{-1}$ (VER2), and compost corresponding to $8 \mathrm{~g} \mathrm{~N}_{\text {pot }}{ }^{-1}$ (CPF2) resulted in net $\mathrm{N}$ mineralization approximately double that that reported for soils amended with compost corresponding to $4 \mathrm{~g} \mathrm{~N}$ pot $^{-1}$ (CPF1). However, results of the $\mathrm{N}$ incubation experiment gave general indications of $\mathrm{N}$ availability for crops and suggested that application of composted and vermicomposted cotton residues for a period longer than three weeks before sowing the subsequent crops may subject $\mathrm{N}$ to losses.

In order to find an alternative of burning cotton residues, part of this work also investigated the efficacy of compost and vermicompost to suppress bacterial blight. Infected cotton residues was collected and processed under composting and vermicomposting. Fresh samples were monthly collected and cultured in a semi-selective media following the serial dilution method. Pathogen numbers was counted as colony forming units per fresh weight after 3-4 days incubation under optimum conditions.

Results showed that the reduction in the pathogen population (calculated as the difference between pathogen population in the compost and the control) considerably varied. For the compost, the values were $<2 \%$ after 30 days, $>40 \%$ after 60 days and around $38 \%$ after 150 days of decomposition. While for the vermicompost, the reductions were $>10 \%$ after 30 days, $>22 \%$ after 60 and $>88 \%$ for samples taken at 150 days. The results also 
showed that the highest pathogens number was found during the first sampling date and consequently decreased with time $(r=0.71 ; P \leq 0.0001)$. This study concluded that both composting and vermicomposting succeeded to mitigate colony forming units (CFU $\mathrm{g}$ fresh material ${ }^{-1}$ ) of the pathogens and proposed them as possible processes to manage the infected cotton residues instead of burning.

Overall, the study (1) proposed that composting and vermicomposting can be used as possible processes to manage the infected cotton residues instead of burning, (2) suggested that the reduction in $\mathrm{C}: \mathrm{N}$ ratio with time can be taken as a reliable parameter to mirror the progress in decomposition especially when combined with $\mathrm{NH}_{4}-\mathrm{N}, \mathrm{NO}_{3}-\mathrm{N}$, $\mathrm{pH}$, and $\mathrm{EC}$ for vermicomposting and while with $\mathrm{NH}_{4}-\mathrm{N}, \mathrm{pH}$, and $\mathrm{EC}$ for composting, (3) recommended that 240 ton $\mathrm{ha}^{-1}$ of the finished compost and vermicompost can be applied for agricultural purposes. Additionally, this work suggested simple and practical procedures for composting and vermicomposting of the organic wastes that can constructed from local materials and method to rear earthworms for vermicomposting and different other purposes. 


\section{Zusammenfassung}

Der Einsatz von organischen Reststoffen zum Anheben oder Stabilisieren des Humusgehaltes als auch um langfristig die Bodenfruchtbarkeit $\mathrm{zu}$ verbessern, hat zunehmend an Bedeutung zur Verbesserung der Gesundheit des Bodens und der Bodenproduktivität gewonnen. Die Umwandlung von Ernterückständen, um Bodeneigenschaften zu verbessern, hängt von der Qualität und dem Zustand der Stoffe $\mathrm{ab}$, diese hängen wiederum von der Zusammensetzung des Ausgangsmaterials ab. In Entwicklungsländern werden die meisten Ernterückstände als Tierfutter oder auch als Baumaterial genutzt, viele werden auch als Ersatzbrennstoff für Holz genutzt; zur Vorbereitung des Bodens zur nächsten Ernte oder zur Bekämpfung von Pflanzenkrankheiten und Schadinsekten werden die Reststoffe oftmals verbrannt.

Vom Brennen muss abgeraten werden, da die organische Substanz verloren geht und gleichzeitig ein Verlust der flüchtigen Elemente wie Stickstoff und Schwefel erfolgt, nur bei einer absoluten Notwendigkeit zur Schädlingsbekämpfung sollten die Reststoffe verbrannt werden. Im Sudan werden jährlich am Ende eines jeden Vegetationsperiode landwirtschaftliche Reststoffe vernichtet; insbesondere Baumwollrückstände werden jährlich verbrannt, um die Ausbreitung von Bakterien und der Knollenfäule, die 35\% Verluste in der nachfolgenden Saison verursacht, zu verhindern.

Diese Studie wurde in zwei Teilen durchgeführt, ein Labor- und GewächshausExperiment am Department für Nutzpflanzenwissenschaften der Universität Göttingen, Deutschland, ein zweites Experiment an der Fakultät für Landwirtschaft der Universität Khartoum, Sudan. Verschiedene Versuche wurden durchgeführt: Auswertung von Kompostierungsversuchen der Baumwollrückstände, als reguläre, normale Kompostierung und als Vermikompostierung (Zusatz von Regenwürmer) und ein Phytoxizitäts-Bioassay-Test des fertigen Komposts und Vermikomposts, um ihre Eignung für landwirtschaftliche Anwendungen $\mathrm{zu}$ prüfen. Die Ergebnisse dieser Experimente führten zu einem Gefäßversuch, in mit Weidelgras die Nährstoffaufnahme untersucht wurde. Gleichzeitig wurde ein Stickstoff-Inkubationsexperiment durchgeführt, um die Rate des mineralisierten Stickstoffs aus Kompost und Vermikompost zu bewerten. Bei dem Versuch, eine Alternative zur Verbrennung von Baumwollstroh zu 
finden, wurde auch ein Experiment (Anzahl der Kolonie bildenden Einheiten von Mikroorgansimen) durchgeführt, welches die Wirksamkeit der Kompostierung und Vermikompostierung auf die bakterielle Braunfäule der Baumwolle überprüften sollte.

Für diese Arbeit wurde Baumwollstroh aus den landwirtschaftlichen Betrieben der ElGazira Bewässerungslandwirtschaft (El-Gazira State, Sudan) genommen, Bodenproben wurden aus dem Oberboden $(0-30 \mathrm{~cm})$ des Shambat Boden gezogen. Für die experimentellen Arbeiten im Sudan wurde Stallmist (FYM) aus einer Farm in der Nähe der Fakultät für Landwirtschaft, Universität Khartoum, Shambat, genutzt; aus dem Institut für Tierzucht, Universität Göttingen, Deutschland, wurde FYM für die Experimente in Göttingen genutzt.

Eine regelmäßige Analyse der Kompostierungsvorgänge erfolgte durch Gesamt-C und Gesamt-N (trockene Verbrennung mittels einem Elementaranalysator) Bestimmungen; Ammonium- und Nitrat-Gehalte der feldfeucht gezogenen Proben erfolgte mittels MikroKjeldahl Destillationsverfahren, die Summe bildete den mineralischen Stickstoff. Phosphor wurde nach der Molybdat-Blau-Komplex-Methode bestimmt und spektrophotometrisch gemessen. In einem Extrakt im Wasser-Kompost-Verhältnis 10:1 wurde die elektrische Leitfähigkeit und der pH-Wert bestimmt. Einige Makro- und Mikronährstoffe wurden in einem Verfahren unter Verwendung eines Druckaufschlusses gemessen.

Verschiedene Studien wurden an der Universität Göttingen durchgeführt. Die erste Studie charakterisiert das kompostierte und vermikompostierte Baumwollstroh auf seine chemische Zusammensetzung und seinen agronomischen Wert und zielte darauf ab, (1) die chemischen Veränderungen während der Kompostierung und Vermikompostierung aus Baumwollstroh zu bestimmen; und (2) die Ergebnisse der chemischen Veränderungen mit den Daten des Bioassays-Tests zu korrelieren und (3) um die Qualität Parameter, die am besten einen fertigen Kompost und Vermikompost beschreiben, zu bestimmen.

Die Ergebnisse dieses Teils zeigten, dass die Analysen des Komposts und des Vermikomposts eine breite Variation im pH-Wert, Gesamt-N, Gesamt-C, C/N- 
Verhältnis, elketrische Leitfähigkeit (EC) und Mineralstoffgehalt aufweisen. Der fertige Kompost und Vermikompost zeigte folgende Werte des C/N-Verhältnis: 15,4 und 15,2 für Kompost und Vermikompost; pH 6,6 für Kompost und 7,9 für Vermikompost und eine elektrische Leitfähigkeit (EC) von 2,96 dS m$~^{-1}$ und 1,62 $\mathrm{dS} \mathrm{m}^{-1}$ für Kompost und Vermikompost, welches übliche Bereiche für reife Komposte sind (C/N: 15-20; pH: 5,58,0; EC: $4 \mathrm{dS} \mathrm{m}^{-1}$ ) mit Ausnahme der Werte $\mathrm{NH}_{4}-\mathrm{N} / \mathrm{NO}_{3}-\mathrm{N}(1,57)$ der fertigen Komposte, die weit über den empfohlenen Wert $(0,16)$ liegen, während der Wert des fertigen Vermikompost $(0,1)$ unter dem Grenzwert liegt.

Eine Korrelation zwischen $\mathrm{NH}_{4}-\mathrm{N}, \mathrm{NO}_{3}-\mathrm{N}, \mathrm{EC}, \mathrm{C}: \mathrm{N}$, und $\mathrm{pH}$ wurde durchgeführt. Für den Vermikompost lagen die Korrelationskoeffizienten zwischen $\mathrm{C} / \mathrm{N}-$ Verhältnis und $\mathrm{NH}_{4}-\mathrm{N}, \mathrm{NO}_{3}-\mathrm{N}$, pH und EC mit $r=0,86$ bei $(P<0,01),-0,79(P<0,01), 0,91(P<0,01)$ und -0,77 $(P<0,01)$. Die $\mathrm{NH}_{4}$-N-Konzentration war eng zum $\mathrm{NO}_{3}$-N korreliert $(r=-0,95$, $P<0,01)$. Die negative Korrelation zwischen $\mathrm{NH}_{4}-\mathrm{N}$ und $\mathrm{NO}_{3}-\mathrm{N}$ deutet darauf hin, dass das Material einer aktiven biologischen Zersetzung unterlag; dieses Ergebnis wurde mit dem $\mathrm{NH}_{4}-\mathrm{N} / \mathrm{NO}_{3}-\mathrm{N}-$ Verhältnis bestätigt. Die signifikante negative Korrelation zwischen dem $\mathrm{C} / \mathrm{N}-$ Verhältnis und dem $\mathrm{NO}_{3}-\mathrm{N}$ Wert $(r=-0,79, P<0,01)$, dem $\mathrm{C} / \mathrm{N}-$ Verhältnis und dem $\mathrm{NH}_{4}-\mathrm{N}$ Wert gibt die Tendenz der Vermikompostierung wieder. Für den Kompost lagen die Korrelationskoeffizienten zwischen $\mathrm{C} / \mathrm{N}-$ Verhältnis und $\mathrm{NH}_{4}-\mathrm{N}, \mathrm{NO}_{3}-\mathrm{N}, \mathrm{pH}$ und EC mit $r=0,88$ bei $(P<0,01), 0,94(P<0,01), 0,59(P=0,02)$ und $-0,72(P<0,01)$. Die $\mathrm{NH}_{4}$-N-Konzentration war gut mit dem $\mathrm{NO}_{3}-\mathrm{N}$ Wert korreliert $(r=0,80, P<0,01)$. Diese Ergebnisse zeigen, daß die Reduktion im C/N-Verhältnis in der Zeit als ein zuverlässiger Parameter genommen werden kann, um den Fortschritt der Zersetzung darzustellen, wenn sie mit den Daten für $\mathrm{NH}_{4}-\mathrm{N}, \mathrm{NO}_{3}-\mathrm{N}, \mathrm{pH}$ und $\mathrm{EC}$ für den Vermikompost und mit den Daten $\mathrm{NH}_{4}-\mathrm{N}, \mathrm{pH}$ und $\mathrm{EC}$ für den Kompost kombiniert werden.

Organische Materialien können schädliche Auswirkungen auf Pflanzen oder keimenden Samen ausüben, daher wurde ein Phytotoxizitäts-Bioassay-Test als ein wichtiger Indikator für die Qualität durchgeführt, Ziel war es, eine Bewertung der Toxizität und eine Eignung des fertigen Komposts und Vermikomposts aus Baumwollstroh auf die Keimung von Kressesamen zu erhalten. Die Auswirkungen von Wasser-Extrakten 
verschiedener Substrate wurden untersucht, wobei die gekeimten Samen ausgezählt und die Länge der Hauptwurzel der Kresse (Lepidium sativum L.) gemessen wurde. Die Indizes der Keimung für Vermikompost (> 80\%) sind größer als empfohlene Werte für reife Komposte (> 70\%), während der Kompost (> 50\%) diese Werte nicht erzielte. Die Ergebnisse dieser Arbeiten zeigten, dass fertige Vermikomposte am besten in diesem Kresse Bioassay Test abschnitten und als „reife Komposte“ betrachtet werden können, während der Kompost negative Auswirkungen auf die Keimung der Samen zeigte, also noch nicht „reif“" war.

Die Bewertung der fertigen Komposte und Vermikomposte erfolgte in einem Gefäßversuch mit Weidelgras. Ein gleichzeitiges Inkubations-Experiment zur Stickstoffmineralisierung erfolgte unter Laborbedingungen, um Kompost und Vermikompost in ihrer $\mathrm{N}$-Freisetzung $\mathrm{zu}$ bewerten und auch die langfristigen Auswirkungen ihrer Anwendung vorherzusagen. Beide Experimente dienten zur Bestimmung der Leistung von Kompost und Vermikompost auf das Pflanzenwachstum nach einmaliger Anwendung, die Prüfung der Zuverlässigkeit des N-Schicksals erfolgte durch das Inkubations-Experiment zur Beurteilung des potenziell mineralisierbaren Stickstoffs. Der Gefäßversuch erfolgte unter natürlichen Lichtbedingungen und der Umgebungstemperatur. Um dieses $z u$ erreichen, wurde der Gefäßversuch im Gewächshaus des Departments für Nutzpflanzenwissenschaften durchgeführt. Kompost und Vermikompost entsprachen einer $4 \mathrm{~g}$ und $8 \mathrm{~g}$ N-Gabe pro Topf. Der Kompost und Vermikompost des Gefäßversuches wurde auch zur Inkubation genutzt.

Daten aus dem Gefäßversuch zeigten, dass sowohl in den Kompost als auch Vermikompost gedüngten Gefässen die Biomasseerträge nach der zweiten Ernte stark zurückgingen, signifikante Unterschiede $(P<0,05)$ wurde nur für die erste, zweite und letzte Ernte bestimmt. Die Biomasse der ersten und der letzten Ernten der Töpfe mit Vermikompost in der $4 \mathrm{~g}$ N/Topf Variante (VER1) entsprachen 1,4 und $0,1 \mathrm{~g} \mathrm{~kg}^{-1}$, während die Weidelgraserträge im Vermikompostversuch $8 \mathrm{~g}$ N/Topf (VER2) 0,8 $\mathrm{g} \mathrm{kg}^{-1}$ für die erste Ernte und $0,2 \mathrm{~g} \mathrm{~kg}^{-1}$ ergaben., jeweils Weidelgras Biomasse auf Töpfen ausgesät mit Kompost entsprach geändert $8 \mathrm{~g} \mathrm{~N} \mathrm{pot}^{-1}$ (CPF2) waren 1,4 $\mathrm{g} \mathrm{kg}^{-1}$ bei der ersten Ernte und $0,3 \mathrm{~g} \mathrm{~kg}^{-1}$ für die letzte. Der beobachtete Rückgang der Biomasse in 
allen Töpfen mit Kompost oder Vermikompost nach 30 Tagen scheint das Ergebnis einer extremen Verknappung des verfügbaren $\mathrm{N}$ zum Weidelgraswuchs sein, besonders in den Gefäßen, die mit dem Vermikompost gedüngt wurden. Dieses wurde durch die sichtbaren Zeichen des N-Mangels (Chlorose) unterstützt.

Die Ergebnisse zeigten auch, dass sowohl für Kompost und Vermikompost Varianten die Gesamt-N Gehalte des Weidelgrases dem Trend in der Biomasse folgten, wo die höheren $\mathrm{N}-$ Gehalte in ersten Ernte beobachtet wurden und die niedrigsten in der letzten. Die NGehalte waren je nach Kompostgaben 6,1-6,4\% für die Ernte nach 10 Tagen und 2,42,9\% für die Ernte nach 70 Tagen. Die N-Gehalte in den Vermikompost gedüngten Varianten lagen bei 3,7-4,0\% für die Ernte nach 10 Tagen und 1,9-2,1\% für die Ernte nach 70 Tagen. Die N-Gehalte des Weidelgrases der Kompost-Variante lag innerhalb der ausreichenden Versorgung (3-4,2\%) N für ein normales Wachstum, während die Werte der Vermikompost gedüngten Varianten diesem Bereich nur zur Ernte nach 10, 60 und 70 Tagen erfüllten. Die Effizienz der N-Aufnahme war gering (>80\% der N wurde nicht durch die Ernte genutzt).

Die Ergebnisse des N-Inkubations-Experiment zeigte, dass die Höchst-und Mindestwerte des mineralischen $\mathrm{N}$ zwischen den Kompost- und Vermikompost-Aufwandmengen variierten. Dementsprechend betrugen die Werte für die $4 \mathrm{~g} N$ Variante VER1 9,41 bis 44 mg N kg${ }^{-1} ; 13,2$ bis $51,0 \mathrm{mg} \mathrm{N} \mathrm{kg}^{-1}$ für die Vermikompost-Variante $8 \mathrm{~g} \mathrm{~N} \mathrm{Topf}^{-1}$ (VER2), 7,2 bis 27,4 $\mathrm{mg} \mathrm{N} \mathrm{kg}^{-1}$ für die Kompost-Variante, entsprechend $4 \mathrm{~g} \mathrm{~N} \mathrm{Topf}^{-1}$ (CPF1) und 4,2 bis 46,0 $\mathrm{mg} \mathrm{N} \mathrm{kg}^{-1}$ für die Kompost-Variante entsprechend $8 \mathrm{~g} \mathrm{~N}$ Topf $^{-1}$ (CPF2).

Die Netto-N-Mineralisierung am Ende der Inkubationszeit war signifikant $(P<0,001)$ zwischen den Kompost- und Vermikompost - Varianten und deren Aufwandmengen. Die Böden, die mit Vermikompost entsprechend $4 \mathrm{~g} \mathrm{~N}$ Topf $^{-1}$ (VER1), Vermikompost entsprechend $8 \mathrm{~g} \mathrm{~N} \mathrm{Topf}^{-1}$ (VER2) und Kompost entsprechend $8 \mathrm{~g} \mathrm{~N} \mathrm{Topf}^{-1}$ (CPF2) behandelt wurden, erfuhren eine Netto-N-Mineralisierung, die etwa doppelt so hoch war als bei Böden mit Kompost entsprechend $4 \mathrm{~g} \mathrm{~N} \mathrm{Topf}^{-1}$ (CPF1). Allerdings gab Ergebnisse der N Inkubationsexperiment allgemeine Hinweise auf N-Verfügbarkeit für Nutzpflanzen und schlug vor, dass Anwendung von Kompost und vermicomposted Baumwolle 
Rückstände für einen Zeitraum von mehr als drei Wochen vor der Aussaat die nachfolgenden Kulturen unterwerfen N, um Verluste können.

Um eine Alternative zum Verbrennen des Baumwollstrohs zu finden, befasste sich ein Teil dieser Arbeit mit der Wirksamkeit von Kompost und Vermikompost zur Unterdrückung der bakteriellen Braunfäule. Infizierte Baumwolle-Rückstände wurden gesammelt und einer Kompostierung und Vermikompostierung unterzogen. Proben aus den Kompostierungen wurden monatlich gesammelt und in einem semi-selektiven Medium nach der Verdünnungsreihe Methode kultiviert. Die Pathogenität wurde als „Kolonie-bildende-Einheit“ pro Gewicht der frischen Probe nach 3-4 Tagen Inkubation unter optimalen Bedingungen ausgezählt und gewertet.

Die Ergebnisse zeigten, dass die Reduzierung der Erreger (berechnet als Differenz zwischen der Pathogenität in den Komposten und der Kontrolle) erheblich variierte. Für den Kompost betrugen die Werte <2\% nach 30 Tagen, > 40\% nach 60 Tagen und rund $38 \%$ nach 150 Tagen der Zersetzung. Während für den Vermikompost die Reduzierungen $>10 \%$ nach 30 Tagen, > 22\% nach 60 und > 88\% für Proben bei 150 Tagen betrugen. Die Ergebnisse zeigten auch, dass die höchste Zahl Erreger während der ersten Probenahme gefunden wurde und mit der Zeit abnahmen $(r=0,71 ; P \leq 0,0001)$. Diese Studie ergab, dass es sowohl der Kompostierung und der Vermikompostierung gelungen ist, die Kolonie-bildenden Einheiten (CFU g frisches Material ${ }^{-1}$ ) der Erreger zu vermindern. Ein möglicher Prozess, um die infizierten Baumwolle-Rückstände anstelle durch Verbrennung zu behandeln.

Insgesamt ergibt die Arbeit:

(1) die Kompostierung und Vermikompostierung sind ein möglicher Prozess, um die infizierten Baumwoll-Rückstände zu behandeln, anstatt sie zu verbrennen,

(2) die Reduktion des $\mathrm{C} / \mathrm{N}-$ Verhältnisses im Laufe einer Kompostierung als einen zuverlässigen Parameter zum Fortschritt in Zersetzung zu nehmen, besonders, wenn sie mit den Daten $\mathrm{NH}_{4}-\mathrm{N}, \mathrm{NO}_{3}-\mathrm{N}, \mathrm{pH}$ und $\mathrm{EC}$ der Vermikompostierung kombiniert und mit den Daten $\mathrm{NH}_{4}-\mathrm{N}$, pH und EC für die Kompostierung kombiniert wird, 
(3) dass 240 Tonnen ha $^{-1}$ des fertigen Kompost und Vermikompost als Richtschnur für die Landwirtschaft angenommen werden können.

Darüber hinaus schlug diese Arbeit einfache und praktische Verfahren für die Kompostierung und Vermikompostierung der organischen Abfälle, die aus lokalen Ernterückständen stammen, vor und Verfahren zur Regenwurmzucht für die Vermikompostierung und verschiedene andere Zwecke. 


\section{Acronyms and abbreviations}

\begin{tabular}{|c|c|}
\hline ADM & Aerial Dry Matter \\
\hline ANOVA & Analysis Of Variance \\
\hline ANR & Apparent Nitrogen Recovery \\
\hline ARC & Agricultural research Corporation \\
\hline $\mathrm{C}$ & Carbon \\
\hline CRD & Randomized Complete Design \\
\hline $\mathrm{CPF}$ & Composted cotton residues with farm yard manure \\
\hline $\mathrm{C}: \mathrm{N}$ & Carbon to Nitrogen ratio \\
\hline $\mathrm{DM}$ & Dry Matter \\
\hline DMRT & Duncan's Multiple Range Test \\
\hline $\mathrm{dw}$ & dry weight \\
\hline FYM & Farm Yard Manure \\
\hline GDP & Growth Domestic Product \\
\hline $\mathrm{h}$ & hour \\
\hline LSD & Least Significant Difference \\
\hline m.a.s.1 & meter above sea level \\
\hline mins. & minutes \\
\hline $\mathrm{Mg}$ & Mega gram \\
\hline Mt & Million metric tonnes \\
\hline $\mathrm{N}$ & Nitrogen \\
\hline NNUP & Net Nitrogen Uptake \\
\hline $\mathrm{OM}$ & Organic Matter \\
\hline $\mathrm{P}$ & Phosphorus \\
\hline $\mathrm{rpm}$ & rotation per minute \\
\hline $\mathrm{SOM}$ & Soil Organic Matter \\
\hline TOC & Total Organic Carbon \\
\hline TSP & Triple Super Phosphate \\
\hline VER & Vermicomposted cotton residue \\
\hline WHC & Water Holding Capacity \\
\hline
\end{tabular}




\section{Terms used within the texts}

\section{Composting}

Composting is defined into several ways but all definitions came to the same conclusion that composting is an effective useful way of disposal and transforming organic wastes into stable nutritive products for soil applications (Kumar Srivastava et al., 2011; Vinceslas-Akpa \& Loquet, 1997). For instance, composting (from the Latin compositum, meaning mixture) refers to a biodegradation process of a mixture of substrates carried out by a microbial community composed of various populations in aerobic conditions and in the solid state (Insam \& De Bertoldi, 2007).

\section{Compost}

Compost is defined as the product of a biological decomposition and stabilization of organic substrates under conditions that allow high temperatures as a result of biologically produced heat (Fracchia et al., 2006).

\section{Compost disease suppressiveness}

Compost disease suppressiveness is defined as the efficacy of the compost enriched with biological control agents to mitigate phytopathogens or due to the microbial generated temperature (Pugliese et al., 2011).

\section{Crop residues}

Crop residues of common cultivated crops are defined in general as parts of the plants left in the field after crops have been harvested and thrashed or left after pastures are grazed (Kumar \& Goh, 1999).

\section{Ethylene oxide}

Organic compound generated in waterlogged conditions and considered toxic to living organisms (Wong, 1985; Wong \& Chu, 1985).

\section{Minus-N nutrient solution (or nutrient solution devoid of $\mathbf{N}$ )}

The solution consists of $0.002 \mathrm{M} \quad \mathrm{CaSO}_{4} \cdot \mathrm{H}_{2} \mathrm{O} ; \quad 0.002 \mathrm{M} \quad \mathrm{MgSO}_{4} ; 0.005 \mathrm{M}$ $\mathrm{Ca}\left(\mathrm{H}_{2} \mathrm{PO}_{4}\right)_{2} \cdot \mathrm{H}_{2} \mathrm{O}$; and $0.0025 \mathrm{M} \mathrm{K}_{2} \mathrm{SO}_{4}$ (Stanford \& Smith, 1972). 


\section{Nitrogen Utilization (or $\mathrm{N}$ recovery)}

The recovery of mineralized $\mathrm{N}$ by a subsequent crop from either plant residues or fertilizer is the product of net mineralization and the efficiency with which inorganic $\mathrm{N}$ is assimilated by a subsequent crop. This efficiency depends largely on the temporal patterns of net mineralization, plant $\mathrm{N}$ uptake, and $\mathrm{N}$ losses (Kumar \& Goh, 1999).

\section{Net nitrogen mineralization}

Is the difference between $\mathrm{N}$ mineralization and immobilization, and low net $\mathrm{N}$ mineralization does not necessary mean that the mineralization is low, only that the mineralization does not greatly exceed immobilization (Griffin, 2007). Net N mineralization is the difference in exchangeable $\mathrm{NH}_{4}-\mathrm{N}$ and $\mathrm{NO}_{3}-\mathrm{N}$ between two samplings dates.

\section{Potentially mineralizable $\mathbf{N}$}

Is defined as the measure of the active fraction of soil organic $\mathrm{N}$, which is chiefly responsible for mineral $\mathrm{N}$ through microbial action. Mineralizable $\mathrm{N}$ is composed of array of organic substrates including microbial biomass, residues of recent crops and humus (Curtin \& Campbell, 2007).

\section{Synchronization}

Has been defined as temporal patterns of $\mathrm{N}$ release from organic sources that can effectively be managed to coincide with crop uptake (Huntington et al., 1985; Ranells \& Wagger, 1996).

\section{Phytotoxicity}

Phytotoxicity is described as an adverse effect (s) on living plants by substances present in the growth medium, when these substances are taken up and accumulated in plant tissue (Chang et al., 1992). 


\section{The maturity and stability of compost}

The terms are both commonly used to define the degree of decomposition of organic matter even if they are conceptually different. Compost stability refers to the level of activity of the microbial biomass and can be determined by $\mathrm{O}_{2}$ uptake rate, $\mathrm{CO}_{2}$ production rate or by the heat release as a result of the microbial activity (Conti et al., 1997; Iannotti et al., 1994). Compost maturity refers to the degree of decomposition of phytotoxic organic substances produced during the active composting stage (Wu et al., 2000).

\section{Vermicomposting}

Is an eco-technological process that transforms energy-rich and complex organic substances into a stabilized humus-like vermicompost by the joint action of earthworms and microorganisms (Kumar Srivastava et al., 2011).

\section{Vermicompost}

Is the finished product formed by the activities of earthworms from organic residues which characterized with high bioavailable nutrients for plant growth (Atiyeh et al., 2000; Orozco et al., 1996). 


\section{$\underline{\text { References }}$}

Atiyeh, R. M., Dominguez, J., Subler, S., \& Edwards, C. A. (2000). Changes in biochemical properties of cow manure during processing by earthworms (Eisenia andrei, Bouché) and the effects on seedling growth. Pedobiologia, 44, 709-724.

Chang, A. C., Granato, T. C., \& Page, A. L. (1992). A methodology for establishing phytotoxicity criteria for chromium, copper, nickel, and zinc in agricultural land application of municipal sewage sludges. Journal of Environmental Quality, 21, 521-536.

Conti, M. E., Arrigo, N. M., \& Marelli, H. J. (1997). Relationship of soil carbon light fraction, microbial activity, humic acid production and nitrogen fertilization in the decaying process of corn stubble. Biology and Fertility of Soils, 25, 75-78.

Curtin, D., \& Campbell, C. A. (2007). Mineralizable nitrogen. Soil sampling and methods of analysis. 2nd ed. CRC Press, Boca Raton, FL, 599-606.

Fracchia, L., Dohrmann, A. B., Martinotti, M. G., \& Tebbe, C. C. (2006). Bacterial diversity in a finished compost and vermicompost: differences revealed by cultivationindependent analyses of PCR-amplified 16S rRNA genes. Applied Microbiology and Biotechnology, 71, 942-952.

Griffin, T. S. (2007). Estimates of Gross Transformation Rates of Dairy Manure N Using 15 N Pool Dilution. Communications in Soil Science and Plant Analysis, 38, 1451-1465.

Huntington, T. G., Grove, J. H., \& Frye, W. W. (1985). Release and recovery of nitrogen from winter annual cover crops in no-till corn production. Communications in Soil Science and Plant Analysis, 16, 193-211.

Iannotti, D. A., Grebus, M. E., Toth, B. L., Madden, L. V., \& Hoitink, A. J. (1994). Oxygen respirometry to assess stability and maturity of composted municipal solid waste.

Insam, H., \& De Bertoldi, M. (2007). Microbiology of the composting process. In: L. F. Diaz, M. de Bertoldi, W. Bidlingmaier \& E. Stentiford (Eds.), Compost Science and Technology (pp. 25-48). Elsevier: Amsterdam.

Kumar, K., \& Goh, K. M. (1999). Crop residues and management practices: effects on soil quality, soil nitrogen dynamics, crop yield, and nitrogen recovery. Advances in Agronomy, 68, 197-319.

Kumar Srivastava, P., Singh, P. C., Gupta, M., Sinha, A., Vaish, A., Shukla, A., Singh, N., \& Krishna Tewari, S. (2011). Influence of earthworm culture on fertilization potential 
and biological activities of vermicomposts prepared from different plant wastes. Journal of Plant Nutrition and Soil Science, 174, 420-429.

Orozco, F. H., Cegarra, J., Trujillo, L. M., \& Roig, A. (1996). Vermicomposting of coffee pulp using the earthworm Eisenia fetida: effects on $\mathrm{C}$ and $\mathrm{N}$ contents and the availability of nutrients. Biology and Fertility of Soils, 22, 162-166.

Pugliese, M., Liu, B. P., Gullino, M. L., \& Garibaldi, A. (2011). Microbial enrichment of compost with biological control agents to enhance suppressiveness to four soil-borne diseases in greenhouse. Journal for Plant Diseases and Plant Protection (JPDP), 2, 4550 .

Ranells, N. N., \& Wagger, M. G. (1996). Nitrogen release from grass and legume cover crop monocultures and bicultures. Agronomy Journal, 88, 777-782.

Stanford, G. S., \& Smith, S. J. (1972). Nitrogen Mineralization Potentials of Soils 1. Soil Science Society of America Journal, 36, 465-465.

Vinceslas-Akpa, M., \& Loquet, M. (1997). Organic matter translocations in lignocellulosic waste products composted or vermicomposted (Eisenia fetida Andrei): Chemical analysis and ${ }^{13} \mathrm{C}$ CPMAS NMR spectroscopy. Soil Biology and Biochemistry, 29, 751-758.

Wong, M. H. (1985). Phytotoxicity of refuse compost during the process of maturation. Environmental Pollution Series A, Ecological and Biological, 37, 159-174.

Wong, M. H., \& Chu, L. M. (1985). The responses of edible crops treated with extracts of refuse compost of different ages. Agricultural Wastes, 14, 63-74.

Wu, L., Ma, L. Q., \& Martinez, G. A. (2000). Comparison of methods for evaluating stability and maturity of biosolids compost. Journal of Environmental Quality, 29, 424429. 


\section{Table of contents}

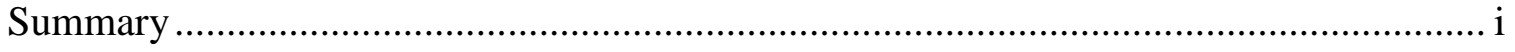

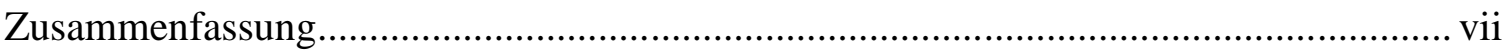

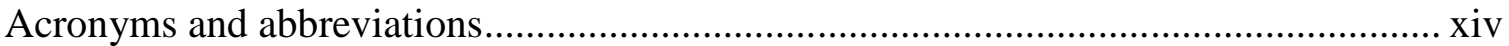

Terms used within the texts ...............................................................................

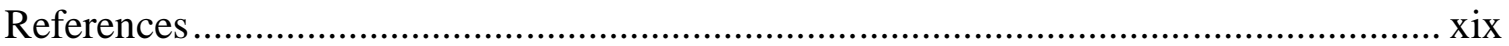

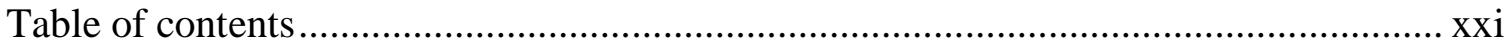

1. The rationale and justifications of the study …………………................................ 1

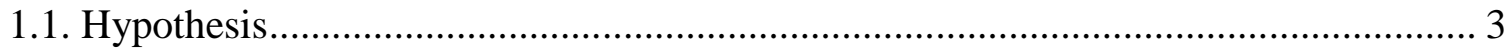

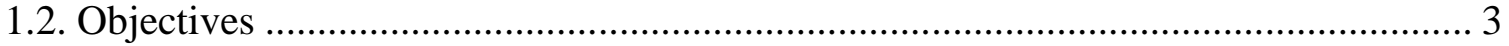

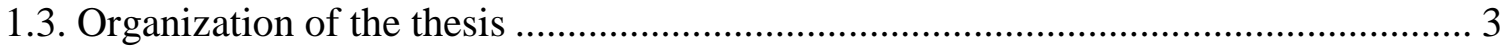

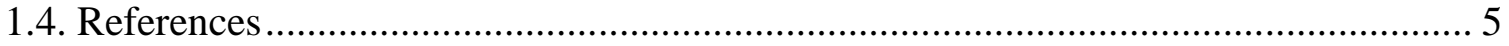

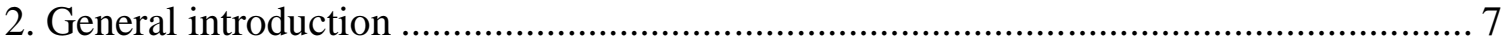

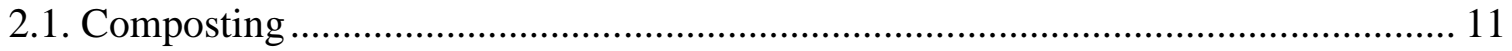

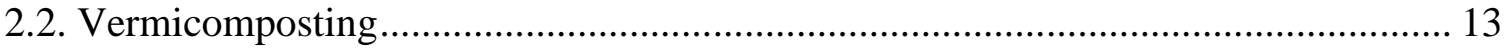

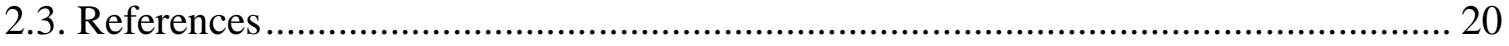

3. Effect of compost and vermicompost on soil organic matter (SOM) and crop nutrients

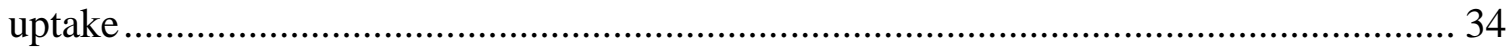

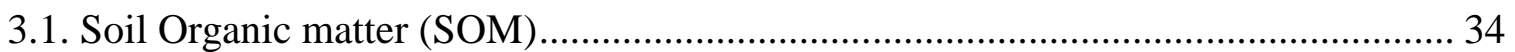

3.2. Soil organic matter in arid and semi-arid regions ................................................. 36

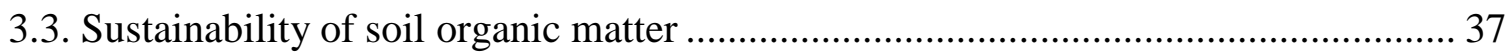

3.4. Role of compost and vermicompost in sustainable farming .................................... 37

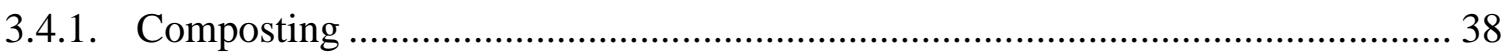

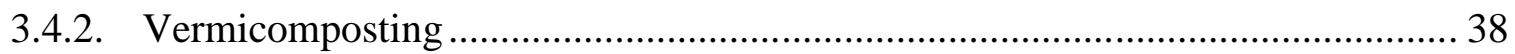

3.5. Factors affecting organic matter decomposition .................................................... 39

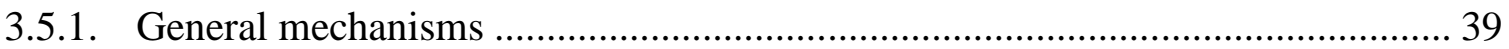

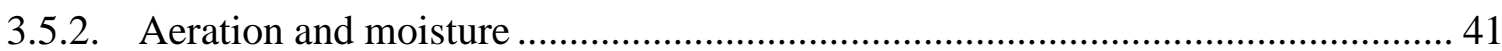

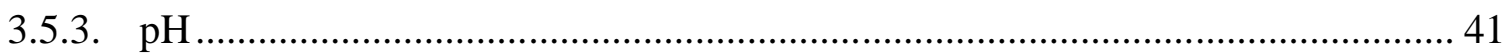

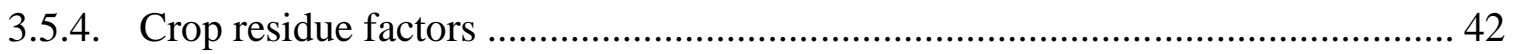

3.6. Crop responses to vermicompost ........................................................................ 43

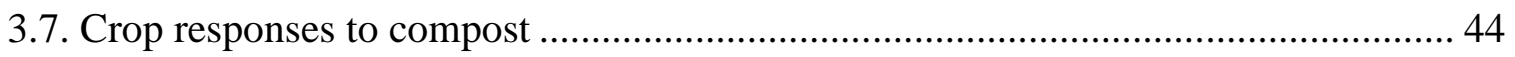

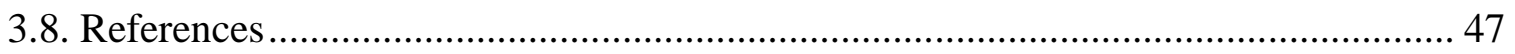

4. Changes of the chemical composition of the cotton residue during decomposition..... 66

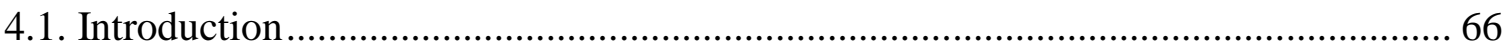




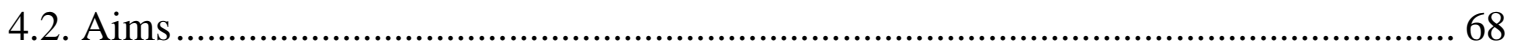

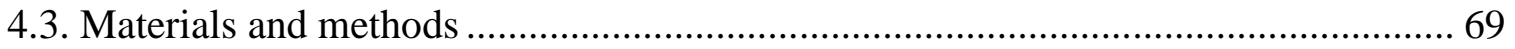

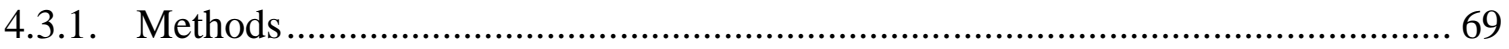

4.3.1.1. Characterization of feedstock and composting ................................................... 69

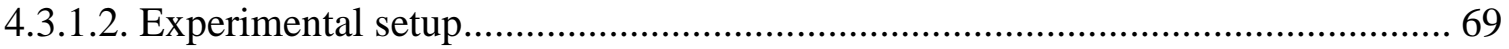

4.3.1.3. Sample collection and preparation ........................................................................ 70

4.3.1.4. Analysis of compost and vermicompost samples ............................................. 70

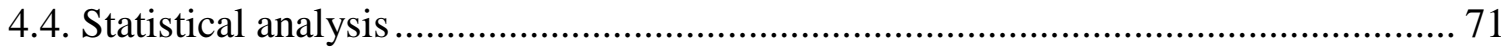

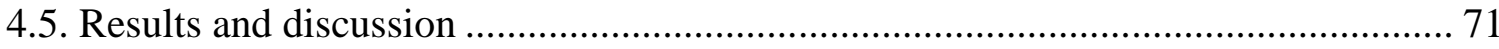

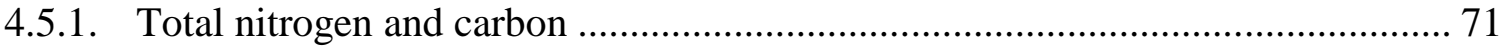

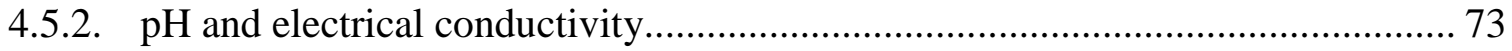

4.5.3. Ammonium, nitrate and total mineral nitrogen ................................................ 77

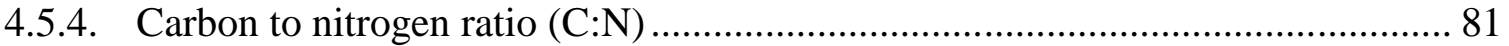

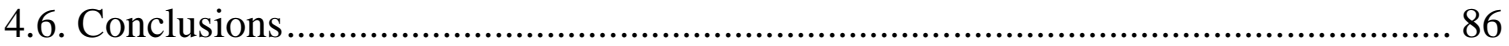

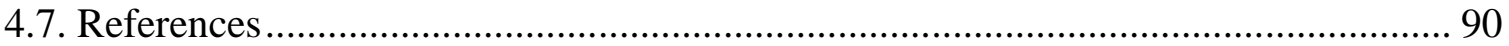

5. Phytotoxicity of compost and vermicompost substrates............................................... 96

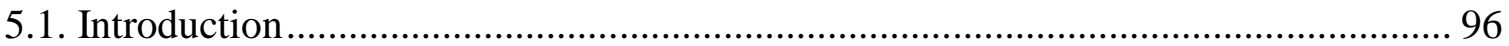

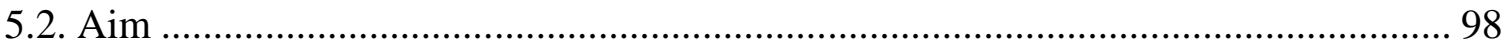

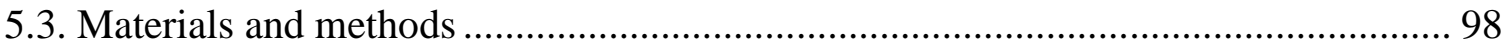

5.3.1. Seed germination test: ............................................................................... 98

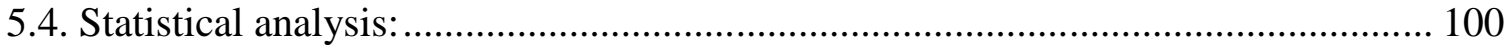

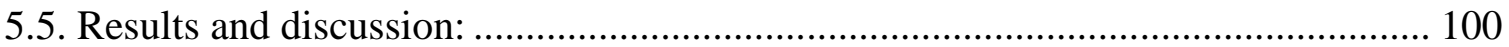

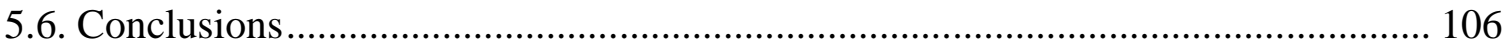

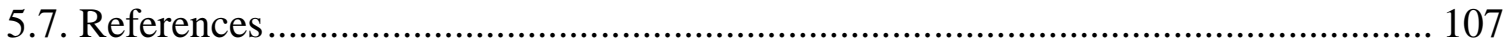

6. Effect of composted and vermicomposted cotton residue on ryegrass (Lolium perene

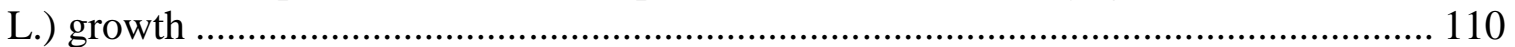

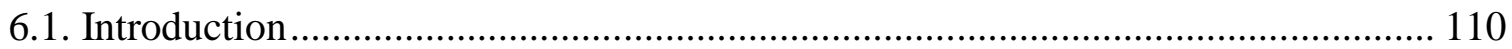

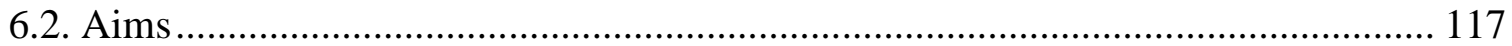

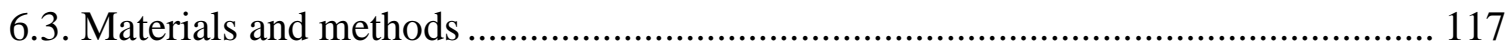

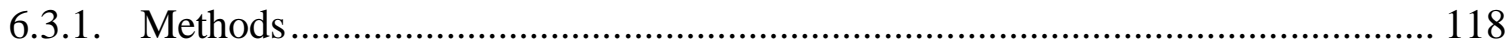

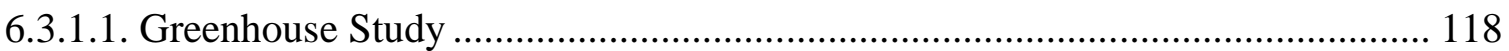

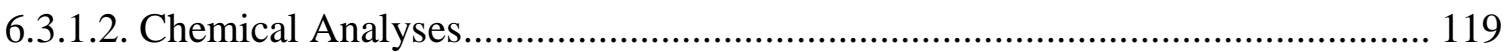

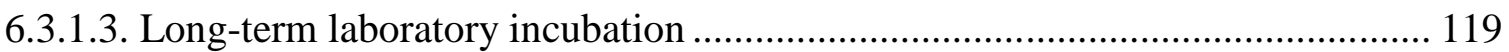

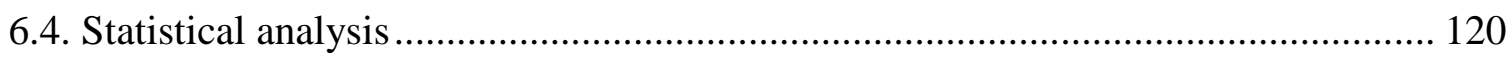




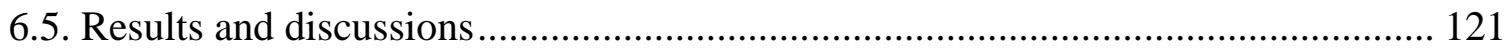

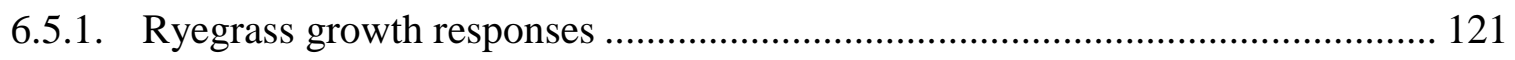

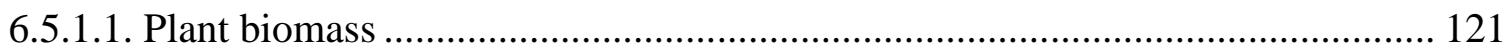

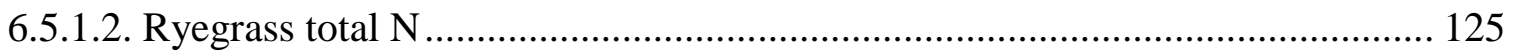

6.5.1.3. Apparent $\mathrm{N}$ recovery \% (ANR) and net $\mathrm{N}$ uptake (NNUP).............................. 127

6.5.1.4. Crop cumulative biomass and net $\mathrm{N}$ uptake ................................................. 133

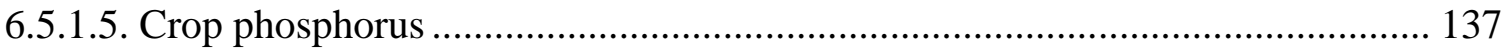

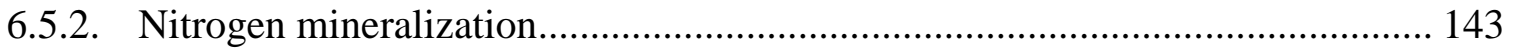

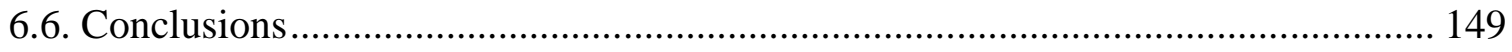

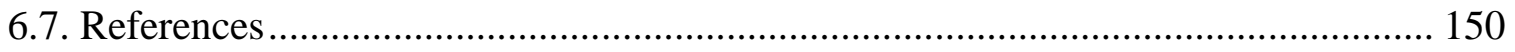

7. Efficacy of Compost and Vermicompost in controlling Cotton Bacterial Blight

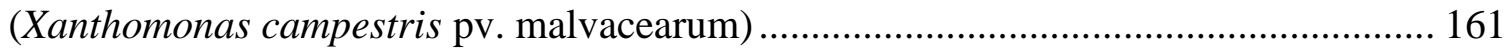

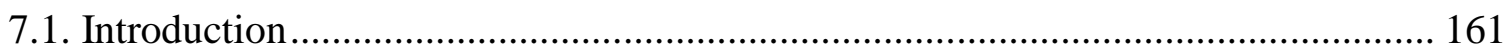

7.1.1. Parameters that relate to compost disease suppressiveness .............................. 162

7.1.2. Compost, vermicompost and materials' maturity ............................................ 163

7.1.3. Microbial succession during the composting and vermicomposting ................. 163

7.1.4. Correlation of disease suppressiveness with microbial characteristics .............. 164

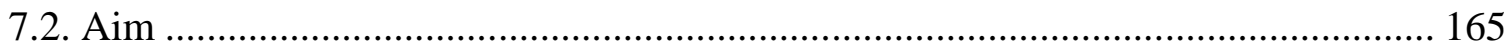

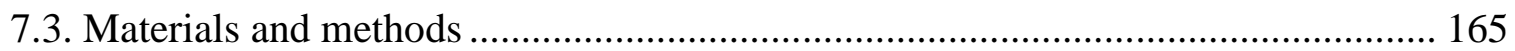

7.3.1. Compost and vermicompost preparation...................................................... 165

7.3.2. Detection of pathogen survival in cotton residues compost and vermicompost 167

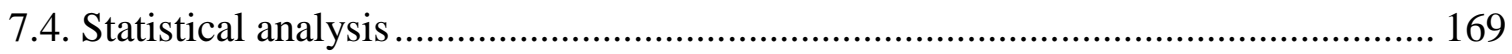

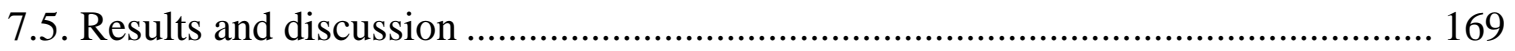

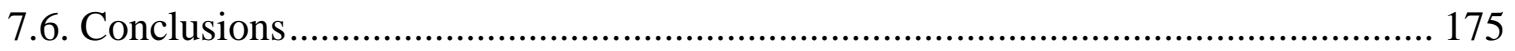

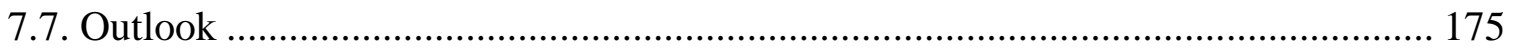

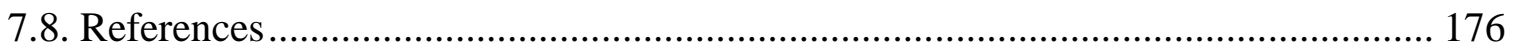

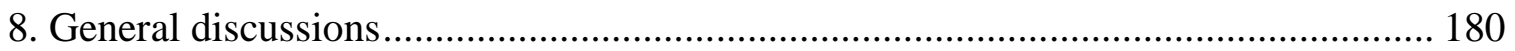

8.1. Implications for using cotton residues for crop growth ....................................... 180

8.2. Implications for mitigating the phytopathogen (Bacterial blight) .......................... 181

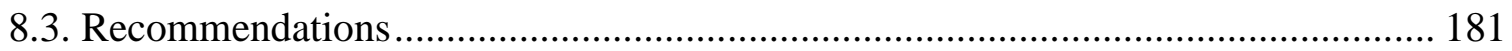

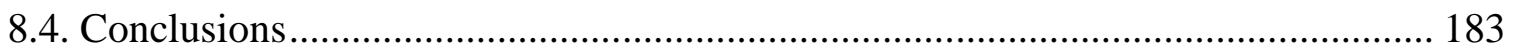

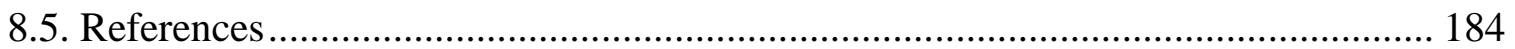

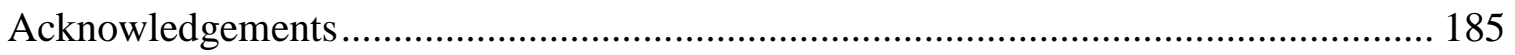

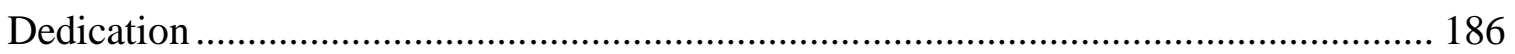


Curriculum Vitae 


\section{The rationale and justifications of the study}

Sudan is the largest country in Africa with more than $60 \%$ of the area within arid and semi-arid zone, which is characterized by low and erratic rainfall. The desert extends from north to south at an alarming rate and about 13 states out of the 26 states of the Sudan are affected by desertification (Salih, 2007). Land degradation as a consequence of desertification is considered as one of the greatest environmental problems in the Sudan, especially when coupled with the increasing demand for feeding the rapidly growing population posing a great pressure on the existing arable lands.

The use of organic manures as amendments to improve soil organic matter level and long term soil fertility and productivity is gaining importance. The benefits of adding composted and vermicomposted organic wastes to soil structure, fertility as well as plant growth have been increasingly emphasized (Chen et al., 1992; Esse et al., 2001; Murwira et al., 1995). Mesophilic and thermophilic microorganisms are involved in the decomposition of organic matter and the succession of these microorganisms is important in the effective management of decomposition process (Beffa et al., 1996; Ishii et al., 2000). Moreover, suppression of pathogens in composting can be achieved with the heat generated during decomposition; on the other hand, the presence of earthworms or use of their body wall and gut extracts also helps in the suppression of pathogens in vermicomposting (Shobha \& Kale, 2008; Stephens \& Davoren, 1997; Stephens et al., 1994). Incorporation of organic materials into the soil is also considered as an economically sound alternative because it provides a locally available source of nutrients, ameliorates soil conditions and reduces the risk of pollution and costs of disposal (Laos et al., 2000; Mafongoya et al., 1996).

In Sudan, about 200 thousand tons of cotton and 500 thousand tons per annum of wheat and tons of other crops residues are annually burnt in the irrigated farming systems of Gezira-Managil (one of the largest state owned farms in the world), which extends over 1,260,000 ha (personal communications Ahmed, 2007). In particular, cotton residues must be collected and quickly burnt in order to prevent spread of residue-borne diseases such as bacterial blight (black-arm disease) which exacerbate up to $35 \%$ loss in 
productivity. This takes place under arid and semi-arid climate zones, where the soil organic matter is in the order of 1-2\%. Although Sudan fertilizers' consumption increased because fertilizers were made to be available through subsidized rates especially in the large irrigated farming systems coupled with the extension services, however fertilizers are still hard to be afforded by the small farmers.

More than $80 \%$ of the population in Sudan depends on agriculture as a source of income and most of the farmers are highly inclined into the local soil fertility management. Agricultural activity in Sudan is contributing about $40 \%$ of the gross domestic product, GDP (Abbadi \& Ahmed, 2006). Over the years, economic growth rates have shown fluctuating trends that coincide with agricultural production being affected by weather conditions, land degradation and unstable political conditions. In the last two decades oil has emerged as a major source for economic growth; in spite of the agricultural contribution to the GDP is fluctuating, but the long-term economic development strategy of the Sudan is the agricultural development by improving the productivity of the agricultural sector and building up on agriculturally based industrial sector. To achieve this goal, increased use of organic amendments and that processed under composting and vermicomposting are key factors to recover soil health, increase crop productivity and consequently farmer's welfare. In addition, the use of composting and vermicomposting may also decrease the adverse effects accompanied with burning crop residues.

Therefore, the importance of this study is to assess the effect of composted and vermicomposted cotton residues as soil conditioners besides their potential to reduce the survival of the cotton black-arm disease. 


\subsection{Hypothesis}

In order to cope with the problem of land degradation, feeding the growing population and to minimize the loss of cotton productivity and the appreciated amount of crop residues, this study intended to test the following hypotheses:

I. Vermicompost promotes plant growth more than compost as it releases more nutrients.

II. Plant growth best responses occur when compost or vermicompost is added in equivalent amounts to the optimum nitrogen mineral fertilizer rates.

III. Compost and vermicompost suppress cotton black-arm disease.

\subsection{Objectives}

The aims of this study were to evaluate the efficiency of composted and vermicomposted cotton residues for plant growth and to mitigate the cotton bacterial blight's colony forming units. To address these aims, the current study will try to answer the following questions:

1. Are decomposed cotton residues suitable for land applications or can be used as constituent of growth medium?

2. Do composted and vermicomposted cotton residues improve soil nutrient contents and enhance plant uptake?

3. Is it better to use composting and vermicomposting as possible tools to prevent the spread of cotton bacterial blight instead of burning the residues?

\subsection{Organization of the thesis}

The motivation for this work and the major objectives addressed here are explained briefly in this section. The thesis is divided into chapters; each one consists of the following: introduction and literature review, methodology, results and discussion, conclusions and recommendations if any.

The work consisted mainly of two major parts; one includes the work that has been carried out in Germany and the second conducted in the Sudan. The organization of the thesis includes general introduction, a chapter about the role of compost and 
vermicompost on soil fertility, organic carbon and their effects on plant growth. At the end of the thesis general conclusions and recommendations have been raised. The thesis also includes the subsequent:

Part one: Where laboratory and green house experiments have been carried out. This part includes the following chapters:

Chapter four: Changes in the chemical composition of the cotton residues during decomposition. This section provides description and evaluation of the decomposition process and quality of the materials produced. It also searches for parameters which can be taken as indexes of materials' maturity and gives some information about $\mathrm{N}$ mineralization patterns.

Chapter five: Phytotoxicity of compost and vermicompost substrates. This section detects whether or not the materials used were phytotoxic for plant growth before being used as growth media.

Chapter six: Effect of composted and vermicomposted cotton residues on ryegrass (Lolium perene L.) growth. This part mirrored the effect of the materials added on plant nutrient uptake and growth.

Part two: Where the preparation of the compost and vermicompost was conducted in Sudan. This part includes the following:

Chapter seven: Efficacy of compost and vermicompost in controlling cotton bacterial blight (Xanthomonas campestris pv. malvacearum). This section reflects the possibility of using composting and vermicomposting instead of residues burning in order to prevent the spread of the bacterial blight. 


\subsection{References}

Abbadi, K. A. B., \& Ahmed, A. E. (2006). Brief overview of Sudan economy and future prospects for agricultural development. Paper presented at the Food Aid Forum, Khartoum, Sudan.

Ahmed, E. (2007). Cotton residues, wheat and different other crops in the GeziraManagil irrigated farming systems. Wad Medani, Sudan.

Beffa, T., Blanc, M., Marilley, L., Fischer, J. L., Lyon, P. F., \& Aragno, M. (1996). Taxonomic and metabolic microbial diversity during composting. In: M. de Bertoldi, P. Sequi, B. Lemmes \& T. Papi (Eds.), The Science of Composting (pp. 149-161). Chapman and Hall: London.

Chen, Y., Inbar, Y., \& Hadar, Y. (1992). Composted residues reduce pest and pesticide use. BioCycle, 48-51.

Esse, P. C., Buerkert, A., Hiernaux, P., \& Assa, A. (2001). Decomposition of and nutrient release from ruminant manure on acid sandy soils in the Sahelian zone of Niger, West Africa. Agriculture, Ecosystems \& Environment, 83, 55-63.

Ishii, K., Fukui, M., \& Takii, S. (2000). Microbial succession during a composting process as evaluated by denaturing gradient gel electrophoresis analysis. Journal of Applied Microbiology, 89, 768-777.

Laos, F., Satti, P., Walter, I., Mazzarino, M. J., \& Moyano, S. (2000). Nutrient availability of composted and noncomposted residues in a Patagonian Xeric Mollisol. Biology and Fertility of Soils, 31, 462-469.

Mafongoya, P. L., Nair, P. K. R., \& Dzowela, B. H. (1996). Multipurpose tree prunings as a source of nitrogen to maize under semiarid conditions in Zimbabwe. Agroforestry Systems, 35, 57-70.

Murwira, K. H., Swift, M. J., \& Frost, P. G. H. (1995). Manure as a key resource in sustainable agriculture. In: J. M. Powell, S. Fernandez-Rivera, T. O. Williams \& C. Renard (Eds.), Livestock and Sustainable Nutrient Cycling in Mixed Farming Systems of Sub-Saharan Africa (pp. 131-148). International Livestock Centre for Africa (II C.A.): Addis Ababa, Ethiopia.

Salih, E. M. (2007). Action programmes for combating desertification UNESCO Chair of Desertification, University of Khartoum: Khartoum North, Sudan. 
Shobha, S. V., \& Kale, R. D. (2008). Invitro studies on cotrol of sil-brne pant pthogens by erthworm Eudrilus Eugeniae exudates. Green Pages, <http://www.ecoweb.com/editorial/080106.html>.

Stephens, P. M., \& Davoren, C. W. (1997). Influence of the earthworms Aporrectodea trapezoides and A. rosea on the disease severity of Rhizoctonia solani on subterranean clover and ryegrass. Soil Biology and Biochemistry, 29, 511-516.

Stephens, P. M., Davoren, C. W., Ryder, M. H., Doube, B. M., \& Correll, R. L. (1994). Field evidence for reduced severity of Rhizoctonia bare-patch disease of wheat, due to the presence of the earthworms Aporrectodea rosea and Aporrectodea trapezoides. Soil Biology and Biochemistry, 26, 1495-1500. 


\section{General introduction}

Soil fertility decline is occurring over large parts of the world, particularly the developing countries. It occurs mainly through intensive and continuous cropping without replenishing the nutrient component of soils and through deforestation and clearance of vegetation (Ayoub, 1999). Therefore, over the last decade's trends in agriculture worldwide were changed to sustain food security, especially with growing population. Consequently, chemical fertilizer use has steadily increased, and this trend is likely to continue in the coming years (FAO, 1990; Zhang \& Zhang, 2007). It is estimated that, by the year 2020, at a universal level, $70 \%$ of plant nutrients will have to come from fertilizers (Ayoub, 1999). In Sudan, the recent consumption of fertilizers is very low compared to the worldwide usage. For instance during 2000-2002, the irrigated sector consumed, expressed in tonnes $\times 10^{3}, 54.3,4.8$ and 3.2 of $\mathrm{N}, \mathrm{P}$ and $\mathrm{K}$ in the form of urea, triple super phosphate (TSP) and $\mathrm{KCl}$, respectively (FAO, 2006). FAO (FAOSTAT, 2011) data show that in the 2002 to 2006 period the annual consumption, mostly used in irrigated agriculture, of the main nutrient sources expressed in tonnes $\times 10^{3}$, ranged as follows: $\mathrm{N}$ (39.7-74.6), $\mathrm{P}(1.3-4.5)$ and $\mathrm{K}(0.0-0.12)$ nevertheless, the use of potash being particularly low.

Improving the use of fertilizers is recently in progress, forming part of the executive program for agricultural development initiated by the Sudan Government for the period of 2008 to 2011. This development strategy necessitates an increase in fertilizer usage to around 100,000 Mt of urea and 50,000 Mt of TSP for the irrigated sector in 2009/2010 for all crops. Future consumption of fertilizers may increase up to 1,000,000 Mt per annum if all the planned irrigable areas are put under cultivation. This aforethought area is defined as the potential land for cultivation; and estimated to be much greater at around 85 million ha. Use of the chemical fertilizers in rain-fed farming, whether mechanized or traditional, is rare (Dawelbeit et al., 2010).

Keeping in view the above ambitious plan, it is well known that most of the soils in the arid zone (e.g., Sudan) are characterized by low organic matter, low $\mathrm{N}$ content, and slow accumulation of organic matter (Ali \& Adam, 2003). In Sudan, constraints which restrict 
the increased use of fertilizers in the irrigated sector are existed, particularly if the main fertilizer is urea. This problem may occur due to the soil surface applications or because of the inherited soil properties, particularly low organic matter and high clay content that create unfavorable conditions. Both reasons may cause loss in $\mathrm{N}$ as ammonia ranging from 30-70 percent of the total $\mathrm{N}$ applied (Dawelbeit, et al., 2010), therefore, proper management of soil organic matter with a judicious use of mineral fertilizers can sustain soil fertility.

Globally, the excessive application of nitrogen fertilizers (organic and mineral) depending on soil texture and climate conditions, could result in high soil nitrate content at the end of the plant growth season, which Consequently, increase the contamination of both underground and surface water (Janzen et al., 2003; Newbould, 1989) and thus inverse environmental impacts (Tilman et al., 2001; Venterea \& Rolston, 2000; Vitousek et al., 1997). Moreover, continuous use of fertilizer alone cannot sustain crop yield and maintain soil fertility in the long term (Shoko et al., 2007; Tisdale et al., 2005).

Improper cultivation practices, such as disposing by removal (baling) or burning of crop residues, which is often criticized for accelerating losses of soil organic matter and nutrients increasing carbon emissions, and reducing soil microbial activity (Kumar \& Goh, 1999) which directly influences soil health and consequently, causes land degradation (Tejada \& Gonzalez, 2004). Removal of crop residue from the field must be balanced against influencing the environment (soil erosion), maintaining soil organic matter levels, and preserving or enhancing productivity (Wilhelm et al., 2004). Therefore, issues of agricultural sustainability and minimizing environmental hazards should be addressed simultaneously. Accordingly, considerable interest in reducing reliance on synthetic fertilizers while maintaining crop yield has been widely dealt with (Kramer et al., 2002). Improvement in soil fertility is intimately connected with increased levels of organic constituents because soil organic matter (SOM) plays vital roles in the functioning of terrestrial ecosystems and agroecosystems, and thereby closely linked with a wide range of ecosystem services (Lavelle et al., 2001; Swift et al., 2004). From agronomic point of view, elevated soil organic matter enhances soil aggregation (Six et al., 2002), this leads to improved soil aeration and root penetration, modifies soil 
hydrodynamic properties and prevents soil erosion (Barthes \& Roose, 2002). Additionally, organic amendments can ameliorate soil with high clay content of sodic subsoil (Clark et al., 2007) and reclaim acid soils (Mitchell \& Alter, 1993).

The use organic inputs have potentials for improving soil productivity and crop yield; therefore, its recycling tends to be important. Inputs from organic sources have been applied worldwide, for instance, animal manure (Haynes \& Naidu, 1998), crop residues (De Neve \& Hofman, 2000; Trinsoutrot et al., 2000), sewage sludge (Albiach et al., 2001; Fließssbach et al., 1994), city refuse (Eriksen et al., 1999; Giusquiani et al., 1995), compost (Chen et al., 1996; Sikora \& Enkiri, 1999; Tejada \& Gonzalez, 2003), and different other by-products with high organic matter content (Sánchez \& Leakey, 1997).

In the developing countries, there is a necessity to search for alternatives to reclaim the vastly degrading soils and substantially reduce the amount of inorganic fertilizers especially when coupled with cash limitations and poor access to fertilizer markets (Rezig et al., 2012). However, surface application or incorporation of animal wastes and plant residues in the top soil to sustain crop production is well practiced and widely appreciated in these areas (Hulugalle et al., 1986; Kowaljow \& Mazzarino, 2007; Smith et al., 1992). The residues left in the field represent a significant resource in terms of organic matter and plant nutrients. The use of crop residues as a soil fertility amendment will enhance the farmers' crop yields and reduce the need for large imports of mineral fertilizers (Rezig, et al., 2012). This, implicitly, will contribute to the savings in the developing countries' scarce financial resources that can be directed to other developmental programmers.

The importance of the quality of the crop residues has long been recognized (Jane et al., 2007; Melillo et al., 1982; Swift et al., 1979), therefore, knowledge of its nutrient contents, mineralization patterns, and effects on crop productivity is important for planning their use in fertility management (Hadas et al., 2004; Watmann \& Kayuki, 2001). The suitability of crop residues as a source of $\mathrm{N}$ depends on the pattern of $\mathrm{N}$ mineralization, which greatly related to the chemical composition, in synchrony with crop demand (Swift, et al., 1979). 
Synchronization has been considered as an important criterion linked to the efficient use of residues (Tilman, et al., 2001). It has been defined as temporal patterns of $\mathrm{N}$ release from organic sources that can effectively be managed to coincide with crop uptake (Huntington et al., 1985; Ranells \& Wagger, 1996; Stute \& Posner, 1995). For instance, if rates of $\mathrm{N}$ release exceed plant demands, subsequently the $\mathrm{N}$ becomes susceptible to various pathways of loss (Khalil et al., 2005; Peoples et al., 2004). Conversely, if rates of $\mathrm{N}$ release are too slow, afterwards crop yields may be constrained. On the other hand, plant residues which decompose fast will provide the growing crops with a large amount of nutrients in early growth stages, but may not affect soil physical conditions, and whereas slowly decomposing plant residues will have opposite effects to the above (Tian et al., 1992).

Quality characteristics as one of the significant factors determines the efficiency of the finished product, include factors like N content, C:N ratio (Franck et al., 1997; Gorissen \& Cotrufo, 2000; Hadas, et al., 2004), lignin, cellulose, hemicellulose and water soluble carbon as well as lignin: $\mathrm{N}$ ratio and the size of residue particles (Frankenberger \& Abdelmagid, 1985; Jane, et al., 2007; Tian, et al., 1992). The levels of sugars, polysaccharides, protein, amino acids and aliphatic acids are also considered to be influential (Haynes, 1986). Nitrogen dynamics could as well be affected by the presence of the ployphenolic content, which has been suggested as one of the criteria that predicts the release of nitrogen (Stevenson, 1994). Due to the wide range of residue quality factors, short-term and long-term net $\mathrm{N}$ mineralization is correlated with different residue properties. Giller and Cadisch (1997) and Hades et al. (2004) concluded that no single index can characterize the quality of plant residues.

Additionally, crop residues' decomposition and nutrient release is governed by the microbial biomass and activity (Cotrufo et al., 1994; Hadas, et al., 2004; Ryckeboer et al., 2003). Decomposition is mainly governed by bacteria and fungi, but the exclusion of macrofauna was reported to reduce the decomposition rate and nutrient release from material (Witkamp \& Ausmus, 1976). Crop residues with different chemical composition vary in their palatability for the soil fauna which are also expected to have differential effects on the populations of the fauna (Swift, et al., 1979; Tian, et al., 1992). 
Hendriksen, (1990) studied the food preference of leaf litter by earthworms and observed that the number of earthworms was significantly and negatively correlated with the C:N ratio and polyphenol concentration.

Efficient management of crop residues for sustainable farming depends mainly on their quality, and the microorganisms involved. This efficiency can be achieved by using the proper decomposition process. Composting and vermicomposting are two of the bestknown processes which widely used for the biological stabilization and management of the organic wastes.

\subsection{Composting}

Composting has been used for many years throughout the world in the stabilization of organic residues. The presence of mixed organic substrates is a prerogative of composting. More specifically, according to its etymological meaning, composting (from the Latin compositum, meaning mixture) refers to a biodegradation process of a mixture of substrates carried out by a microbial community composed of various populations in controlled conditions (aerobic conditions) and in the solid state. Microbial transformation of pure substrates goes under the name of fermentation or biooxidation, but not composting (Insam \& de Bertoldi, 2007).

Two phases can be distinguished in composting: (1) the thermophilic stage, where decomposition takes place more intensively and, which, therefore, constitutes the active phase of composting; and (2) a maturing stage which is distinguished by the decrease of the temperature to the mesophilic range and where the remaining organic compounds are degraded at a slower rate. The duration of the active phase depends on the characteristics of the organic substrate (amount of easily decomposable substances) and on the management of the controlling parameters (aeration and watering). The extent of the maturation phase is also variable, and it is normally marked by the disappearance of the phytotoxic compounds (Lazcano et al., 2008). The composting process leads to the final

production of carbon dioxide, water, minerals, and stabilized organic matter. The main product is called compost, which may be defined as the stabilized and sanitized product of composting, compatible and beneficial to plant growth. The sanitization is maintained 
through the high generated heat during the thermophilic phase which eliminates plant and human pathogens (Fracchia et al., 2006; Lung et al., 2001; Ndegwa \& Thompson, 2001).

Traditional thermophilic composting is commonly adopted and has been defined into several ways; however, all definitions came to the same conclusions; that composting is an effective and useful way of disposal and transformation of organic wastes into a stable valuable organic matter for ameliorating soils (Vinceslas-Akpa \& Loquet, 1997). Composting has been used to address the issue of environmental pollution, where composting avoids the rapid release of nutrients from fresh residues by chemical or biological immobilization, which, consequently, mitigate environmental problems (Cooperband et al., 2002; Cooperband et al., 2000). It has also been used to emphasize the issues of non-reliance on chemical fertilizers, sustainable natural soil fertility, and minimizing the development of new dumps and landfills (Ndegwa \& Thompson, 2001).

Nevertheless, the loss of nitrogen through volatilization of $\mathrm{NH}_{3}$ during the thermophilic stage of the process is one of the major disadvantages of the process at the industrial scale for solid organic waste treatment, although it is well established (Eghball et al., 1997). Other difficulties associated with composting are the long duration of the process, the frequency of turning of the material (Ndegwa \& Thompson, 2001), the material sometimes needs to be reduced in size to provide the required surface area, loss of nutrients during the prolonged composting process, and the heterogeneous nature of the final product makes it less desirable (Ghosh et al., 1999; Riggle \& Holmes, 1994; Subler et al., 1998).

Despite these shortcomings, the beneficial effects of composted amendments on the chemical, physical and biological properties of soils have been well documented. The positive effects are closely linked to the soil condition, application rates and frequency, and organic matter quality (Gabrielle et al., 2004; Giusquiani, et al., 1995; Tu et al., 2006).

The most important factors affecting the successful application of compost for agricultural purposes are its degree of stability and maturity. Therefore, application of unstable or immature compost may inhibit seed germination, reduce plant growth and 
damage crops by competing for oxygen or causing phytotoxicity to plants due to insufficient biodegradation of organic matter (Brewer \& Sullivan, 2003; Cooperband et al., 2003; Wu et al., 2000). In a germination bioassay test, Gariglio et al. (2002) reported that non-composted sawdust of Willow (Salix sp.) inhibited lettuce seed germination while composting increased the germination index (GI) from 5 to $93 \%$ when 0 - and 40day composting time treatments were compared. A effect was reported by Iannotti et al. (1994) who found that at all levels of compost maturity, cress seeds (Lepidium sativum L.) revealed inhibition of germination, and the authors attributed the phytotoxicity to be salt-related. The same authors (Iannotti, et al., 1994) demonstrated that immature compost of municipal solid waste inhibited the growth of radish (Raphanus sativus L.) and ryegrass (Lolium perenne L.). Considering these concerns, extensive research has been conducted to study the composting and to evaluate methods used to describe the stability and maturity of the finished product prior to its agricultural use (Chica et al., 2003; Cooperband, et al., 2003; Zmora-Nahum et al., 2005).

Many studies have also been conducted with various organic wastes; however, the use of cotton residues for agricultural applications worldwide is very limited, and no studies have been carried out in Sudan to investigate their suitability for land applications or for sale into horticultural industries.

The rate of composting has been found to greatly affect the cost-effectiveness and prevention of odors at both processing and process residue levels. A high rate implies lower capital and operational costs, a better-oxygenated ecosystem, and the production of a more stable end-product (Papadimitriou \& Balis, 1996.), therefore, in recent times, interest in the use of a closely-related technique, known as vermicomposting has increased (Edwards \& Bohlen, 1996; Hand et al., 1988a; Logsdon, 1994).

\subsection{Vermicomposting}

Soil fauna are increasingly recognized to have a significant role in soil function and processes affecting nutrient availability for microorganism and crop performance (Ouedraogo et al., 2006). Species such as earthworms and termites produce biogenic structures and thus modify the physicochemical environment of other organisms 
(Blanchart et al., 1999; Brown et al., 2000). Therefore, earthworms have been long recognized by the farmers as a beneficial to soil (Edwards \& Lofty, 1972) and have been called soil engineers (Jones et al., 1994; Lavelle et al., 1997). Earthworms are considered to be key biological agents in consuming, fragmenting, and intimately mixing organic matter with soil mineral particles to form water stable aggregates and consequently, modify soil hydrodynamic and many other desirable characteristics (Blanchart, et al., 1999; Edwards, 2004), homogenous, with desirable aesthetics, plant growth hormones and high levels of soil enzymes, tending to hold more available nutrients over longer periods (Ndegwa \& Thompson, 2001), and beneficial potential as plant growth media named vermicompost (Atiyeh et al., 2002; Butt, 1993; Dominguez \& Edwards, 1997). Similarly, industrial wastes such as guar gum waste, paper pulp, and distillery wastes have been vermicomposted and turned into nutrient-rich manure (Sundaravadivel \& Ismail, 1995; Suthar, 2006; Suthar, 2007).

Vermicomposting using earthworms as natural bioreactors for effective recycling of organic wastes is an environmentally acceptable which defined also as a low cost technology system (Hand et al., 1988b). This process is a mesophilic (Edwards, 1995); during feeding, earthworms enhance aeration and bioturbation of the materials, promote microbial activity and help to accelerate the transformation of organic matter by breaking down large pieces into small ones with increased surface area.

As in traditional composting, i.e. without earthworms, fungi and bacteria are the main actors governing the transformations of organic molecules, and their activity is thus a key factor in soil organic matter dynamics, therefore, composting may be improved and hastened to a significant extent by the combined action of earthworms and microflora (Kale et al., 1982; Tomati et al., 1983; Vinceslas-Akpa \& Loquet, 1997). Therefore, two phases can also be distinguished here, (i) an active phase where the earthworms process the waste modifying its physical state and microbial composition (Lores et al., 2006), and (ii) a maturation-like phase where the microbes take over in the decomposition of the waste. Like in composting, the duration of the active phase is not fixed, and it will depend on the species and density of earthworms, the main drivers of the process, and their ability to ingest the waste (ingestion rate) (Lazcano, et al., 2008). 
In vermicomposting the improvement of ligninolytic, celluloytic and nutrient activities by earthworms and microflora interactions have to be related (Vinceslas-Akpa \& Loquet, 1997). Therefore, vermicomposting has been used to examine the extent of reduction of inorganic fertilizers by applying the finished product as an organic source and its effect on the yield and quality of crops. In which vermicompost has been enriched by beneficial microbes (P-solubilizing and $\mathrm{N}$-fixing organisms) to increase the fertilizer value and reduce the dose of application (Padmavathiamma et al., 2008). Padmavathiamma and his coworkers (2008) reported that as a bioinoculant, vermicompost increased nitrogen and phosphorous availability by enhancing biological nitrogen fixation and phosphorous solubilisation.

Any use of organic wastes must, however, consider potential hazards to the environment, as well as benefits such as cost savings. Earthworms could provide an index to the bioavailability of heavy metals that might be present in the materials who are to be bioconverted, giving an indication of possible environmental hazards (Maboeta \& Rensburg, 2003). Vermicomposting can also be used in the removal of toxic metals within the organic wastes and the breakdown of complex chemicals to non-toxic forms (Jain et al., 2004). It can furthermore be used as a bioremedial measure to reclaim problem soils, especially acid soils, because of the near-neutral to alkaline $\mathrm{pH}$ of vermicompost and the suppression of labile aluminium (Mitchell \& Alter, 1993).

Organic matter plays a key role to achieve sustainability in agricultural production; therefore, composts and vermicompost can be used to improve horticultural or cultivated soil. The desirable properties possessed by these products can be twofold, an improvement of soil nutrients and structure to stimulate plant growth (Albiach, et al., 2001) such as high water-holding capacity, cation exchange capacity (CEC), ability to sequester contaminants (both organic and inorganic) and beneficial effects on the physical, chemical and biological characteristics of soil and a suppressive effect on soil indigenous plant pathogens (Bailey \& Lazarovits, 2003). Additionally, there is considerable evidence that human pathogens do not survive the vermicomposting process (Edwards \& Bohlen, 1996). 
Although several studies have been conducted to compare the efficacy of compost and vermicompost in terms of physical, chemical, and biological parameters, which have been suggested as indicators of compost stability, and their value as organic fertilizer has been also tested, it is not easy to compare these products based on exact values and the threshold values. The threshold values may not be applicable to all types of compost and vermicompost, given the variety of parent wastes and feedstock as well as the composting processes (more or less controlled) from which they are originated. Moreover, a great deal of overlap between the nutrient contents of the compost and vermicompost, and it is not always possible to tell one from the other based on the chemical analysis (Subler, et al., 1998). In this sense, general statements will be used for such comparisons as shown in the following table (Table 2.1). 
Table 2.1: General comparisons between compost and vermicompost

\begin{tabular}{|c|c|c|c|}
\hline Criteria & Compost & Vermicompost & Reference \\
\hline Humic fraction & & higher & (Padmavathiamma, et al., 2008) \\
\hline Oxidisable carbon & higher & & (Padmavathiamma, et al., 2008) \\
\hline Humic acid & & higher & $\begin{array}{l}\text { (Ferreira et al., 1992; } \\
\text { Padmavathiamma, et al., 2008) }\end{array}$ \\
\hline Humic:fluvic acid & & higher & (Padmavathiamma, et al., 2008) \\
\hline Total N & & higher & $\begin{array}{l}\text { (Bano et al., 1987; } \\
\text { Padmavathiamma, et al., 2008; } \\
\text { Syres \& Springett, 1984) }\end{array}$ \\
\hline Total carbon & & lower & (Lazcano, et al., 2008) \\
\hline $\mathrm{C}: \mathrm{N}$ & & $\begin{array}{l}\text { Lower and } \\
\text { decrease rapidly } \\
\text { with time }\end{array}$ & $\begin{array}{l}\text { (Gupta \& Garg, 2008; Lazcano, et } \\
\text { al., 2008; Padmavathiamma, et al., } \\
\text { 2008) }\end{array}$ \\
\hline CEC & no sig. diff. & & (Padmavathiamma, et al., 2008) \\
\hline $\mathrm{pH}$ & acidic & $\begin{array}{l}\text { neutral to alkaline } \\
\text { lower } \mathrm{pH} \text { values }\end{array}$ & (Padmavathiamma, et al., 2008) \\
\hline $\mathrm{EC}$ & & higher & $\begin{array}{l}\text { (Lazcano, et al., 2008; Mitchell, } \\
\text { 1997; Pattnaik \& Reddy, 2010; } \\
\text { Villar et al., 1993) }\end{array}$ \\
\hline $\begin{array}{l}\text { Major nutrients } \\
(\mathrm{N}, \mathrm{P}, \mathrm{K}, \mathrm{Ca} \text { and } \\
\mathrm{Mg}) \\
\text { concentrations }\end{array}$ & & $\begin{array}{l}\text { significantly } \\
\text { higher and readily } \\
\text { available for plant } \\
\text { uptake }\end{array}$ & $\begin{array}{l}\text { (Atiyeh et al., 2000; Pattnaik \& } \\
\text { Reddy, 2010; Tognetti et al., 2005) }\end{array}$ \\
\hline $\begin{array}{l}\mathrm{NH}_{4}-\mathrm{N} \\
\mathrm{NO}_{3}-\mathrm{N}\end{array}$ & $\begin{array}{l}\text { very high } \\
\text { conc. } \\
\text { very low conc. }\end{array}$ & $\begin{array}{l}\text { very low conc. } \\
\text { very high conc. }\end{array}$ & $\begin{array}{l}\text { (Frederickson et al., 2007; Short et } \\
\text { al., 1999; Subler, et al., 1998) } \\
\text { (Mupondi et al., 2010; Subler, et } \\
\text { al., 1998) }\end{array}$ \\
\hline
\end{tabular}

CEC: Cation exchange capacity; EC: electrical conductivity. 
Contin. Table 2.1: Comparisons between compost and vermicompost

\begin{tabular}{|c|c|c|c|}
\hline Criteria & Compost & Vermicompost & Reference \\
\hline $\begin{array}{l}\text { Microbial } \\
\text { biomass }\end{array}$ & $\begin{array}{l}\text { active face } \\
\text { does not } \\
\text { reduce it }\end{array}$ & reduced with time & $\begin{array}{l}\text { (Lazcano, et al., 2008; Tognetti, } \\
\text { et al., 2005) }\end{array}$ \\
\hline Plant $\mathrm{N}$ uptake & & higher & (Padmavathiamma, et al., 2008) \\
\hline Plant P uptake & & higher & $\begin{array}{l}\text { (Mackey et al., 1982; } \\
\text { Padmavathiamma, et al., 2008) }\end{array}$ \\
\hline Plant K uptake & \multicolumn{2}{|c|}{ no sig. diff. } & (Padmavathiamma, et al., 2008) \\
\hline Crop yields & & increased & $\begin{array}{l}\text { (Atiyeh et al., 2001; Kalantari et } \\
\text { al., 2011; Tognetti, et al., 2005) }\end{array}$ \\
\hline $\begin{array}{l}\text { When mixed with } \\
\text { soil }\end{array}$ & & $\begin{array}{l}\text { higher microbial } \\
\text { populations size and } \\
\text { activity }\end{array}$ & (Tognetti, et al., 2005) \\
\hline
\end{tabular}

In summary, the application of composting and vermicomposting for the processing of agricultural wastes and their use as environmental protection measures, soil improvers and nutrient suppliers are well documented. Most of the studies highlighted the significance of the quality of the crop residues as an important factor determines the efficacy of the process and the agronomic value of the final product.

In Sudan, crop residues are in sufficient abundance in the farmers' fields at the end of a growing season. However, farmers in Sudan have not adopted the incorporation of crop residues partly because they have no adequate information about the nutrient values of these residues or crop residues are used by animals. Understanding the contribution of recycling of crop residues and other organic materials on soil quality is important (Rezig, et al., 2012). Moreover, investigations on cotton residues are currently limited worldwide and nearly absent in Sudan. Hence we attempted to convert the considerable quantity of residues produced annually, which normally burnt to prevent the spread of the cotton bacterial blight and/or used for domestic purposes into an opportunity to produce finished products capable of ameliorating the inherited poor soil properties and improving the crop quality. Both reasons coupled with the unaffordable mineral fertilizers for the small farmers gave the motivation to study the decomposition of these residues aiming to find practical indices for its maturity and suitability and to study the efficacy of composting 
and vermicomposting in reducing the cotton bacterial blight's colony-forming units. Although conventional composting, i.e. without earthworms, is currently in use, this method is time consuming. Therefore, there is a pressing need to find out a cost-effective alternative method of shorter duration particularly suited the local conditions. 


\subsection{References}

Albiach, R., Canet, R., Pomares, F., \& Ingelmo, F. (2001). Organic matter components and aggregate stability after the application of different amendments to a horticultural soil. Bioresource Technology, 76, 125-129.

Ali, Z. A., \& Adam, A. I. (2003). Effect of three organic manures on some physical and chemical properties of Khashm Elgirba soil series. Gezira Journal of Agricultural Science, 1, 1-9.

Atiyeh, R. M., Arancon, N. Q., Edwards, C. A., \& Metzger, J. D. (2002). The influence of earthworm-processed pig manure on the growth and productivity of marigolds. Bioresource Technology, 81, 103-108.

Atiyeh, R. M., Edwards, C. A., Subler, S., \& Metzger, J. D. (2001). Pig manure vermicompost as a component of a horticultural bedding plant medium: effects on physicochemical properties and plant growth. Bioresource Technology, 78, 11-20.

Atiyeh, R. M., Subler, S., Edwards, C. A., Bachman, G., Metzger, J. D., \& Shuster, W. (2000). Effects of vermicomposts and composts on plant growth in horticultural container media and soil. Pedobiologia, 44, 579-590.

Ayoub, A. T. (1999). Fertilizers and the environment. Nutrient Cycling in Agroecosystems, 55, 117-121.

Bailey, K. L., \& Lazarovits, G. (2003). Suppressing soil-borne diseases with residue management and organic amendments. Soil and Tillage Research, 72, 169-180.

Bano, K., Kale, R. D., \& Gajanan, G. N. (1987). Culturing of earthworm Eudrilus eugeniae for cast production and assessment of worm cast as biofertilizer. Journal of Soil Biology and Ecology, 7, 98-104.

Barthes, B., \& Roose, E. (2002). Aggregate stability as an indicator of soil susceptibility to runoff and erosion; validation at several levels. Catena, 47, 133-149. 
Blanchart, E., Albrecht, A., Alegre, J., Duboisset, A., Gilot, C., Pashanasi, B., Lavelle, P., \& Brussaard, L. (1999). Effects of earthworms on soil structure and physical properties. Earthworm management in tropical agroecosystems. CAB International, Wallingford, UK. p, 149-172.

Brewer, L. J., \& Sullivan, D. M. (2003). Maturity and stability evaluation of composted yard trimmings. Compost Science and Utilization, 11, 96-112.

Brown, G. G., Barois, I., \& Lavelle, P. (2000). Regulation of soil organic matter dynamics and microbial activityin the drilosphere and the role of interactionswith other edaphic functional domains. European Journal of Soil Biology, 36, 177-198.

Butt, K. R. (1993). Utilization of solid paper-mill sludge and spent brewery yeast as feed for soil dwelling earthworms. Bioresource Technology, 44, 105-107.

Chen, L., Dick, W. A., Streeter, J. G., \& Hoitink, H. A. J. (1996). Ryegrass utilization of nutrients released from composted biosolids and crow manure. Compost Scicience and Utilization, 4, 73-83.

Chica, A., Mohedo, J. J., Martin, M. A., \& Martin, A. (2003). Determination of the stability of MSW compost using a respirometric technique. Compost Science \& Utilization, 11, 169-175.

Clark, G. J., Dodgshun, N., Sale, P. W. G., \& Tang, C. (2007). Changes in chemical and biological properties of a sodic clay subsoil with addition of organic amendments. Soil Biology and Biochemistry, 39, 2806-2817.

Cooperband, L., Bollero, G., \& Coale, F. (2002). Effect of poultry litter and composts on soil nitrogen and phosphorus availability and corn production. Nutrient Cycling in Agroecosystems, 62, 185-194.

Cooperband, L. R., Power, J. F., Dick, W. A., Kashmanian, R. M., Sims, J. T., Wright, R. J., Dawson, M. D., \& Bezdicek, D. (2000). Sustainable use of by-products in land 
management. Land application of agricultural, industrial, and municipal by-products, 215-235.

Cooperband, L. R., Stone, A. G., Fryda, M. R., \& Ravet, J. L. (2003). Relating compost measures of stability and maturity to plant growth. Compost Science \& Utilization, 11, 113-124.

Cotrufo, M. F., Ineson, P., \& Rowland, A. P. (1994). Decomposition of tree leaf litters grown under elevated CO2: effect of litter quality. Plant and Soil, 163, 121-130.

Dawelbeit, S. E., Salih, F. M., Dahab, O. A., \& Ahmed, E. H. (2010). Status of Fertilization and Crop Nutrition in Irrigated Agriculture in Sudan 1: Fertilizer Use in Sudan. Electronic International Fertilizer Correspondent (e-ifc), 22, 2-5.

De Neve, S., \& Hofman, G. (2000). Influence of soil compaction on carbon and nitrogen mineralization of soil organic matter and crop residues. Biology and Fertility of Soils, 30, 544-549.

Dominguez, J., \& Edwards, C. A. (1997). Effects of stocking rate and moisture content on the growth and maturation of Eisena anderi (Oligochaeta) in pig manure. Soil Biology and Biochemistry, 29, 743- 746.

Edwards, C. A. (1995). Historical overview of vermicomposting. Biocycle, 36, 56-58.

Edwards, C. A. (2004). Earthworm ecology (2 ed.). Washington, D.C., USA: CRC Press.

Edwards, C. A., \& Bohlen, P. J. (1996). Biology and ecology of earthworms. London, SE1 8HN, UK.: Chapman \& Hall,2-6 Boundary Row.

Edwards, C. A., \& Lofty, J. R. (1972). Biology of Earthworms, Chapman and Hall: London.

Eghball, B., Power, J. F., Gilley, J. E., \& Doran, J. W. (1997). Nutrient, carbon, and mass loss during composting of beef cattle feedlot manure. Journal of Environmental Quality, 26, 189-193. 
Eriksen, G. N., Coale, F. J., \& Bollero, G. A. (1999). Soil nitrogen dynamics and maize production in municipal solid waste amended soil. Agronomy Journal, 91, 1009-1016.

FAO. (1990). Integrated plant nutrient systems: state of the art: Commission on Fertilizers. Rome: FAO.

FAO. (2006). Fertilizer use by crop in the Sudan. Land and plant management service Rome, Italy.: FAO.

$\begin{array}{lllll}\text { FAOSTAT. (2011). } & \text { Retrieved } 20 \text { June 2011, } & \text { from }\end{array}$ http://faostat.fao.org/site/575/default.aspx\#ancor

Ferreira, M. E., Cruz, M. C. P., \& Da Cruz, M. C. P. (1992). Effects of a compost from municipal wastes digested by earthworms on the dry matter production of maize and on soil properties. Cientifica 20, 217-226.

Fließssbach, A., Martens, R., \& Reber, H. H. (1994). Soil microbial biomass and microbial activity in soils treated with heavy metal contaminated sewage sludge. Soil Biology and Biochemistry, 26, 1201-1205.

Fracchia, L., Dohrmann, A. B., Martinotti, M. G., \& Tebbe, C. C. (2006). Bacterial diversity in a finished compost and vermicompost: differences revealed by cultivationindependent analyses of PCR-amplified 16S rRNA genes. Applied Microbiology and Biotechnology, 71, 942-952.

Franck, V. M., Hungate, B. A., Chapin, F. S., \& Field, C. B. (1997). Decomposition of litter produced under elevated CO 2: dependence on plant species and nutrient supply. Biogeochemistry, 36, 223-237.

Frankenberger, W. T., \& Abdelmagid, H. M. (1985). Kinetic parameters of nitrogen mineralization rates of leguminous crops incorporated into soil. Plant and Soil, 87, 257271. 
Frederickson, J., Howell, G., \& Hobson, A. M. (2007). Effect of pre-composting and vermicomposting on compost characteristics. European Journal of Soil Biology, 43, S320-S326.

Gabrielle, B., Da-Silveira, J., Houot, S., \& Francou, C. (2004). Simulating urban waste compost effects on carbon and nitrogen dynamics using a biochemical index. J. Environ. Qual, 33, 2333-2342.

Gariglio, N. F., Buyatti, M. A., Pilatti, R. A., Russia, D. E. G., \& Acosta, M. R. (2002). Use of a germination bioassay to test compost maturity of willow (Salix sp.) sawdust. New Zealand Journal of Crop and Horticultural Science, 30, 135-139.

Ghosh, M., Chattopadhyay, G. N., \& Baral, K. (1999). Transformation of phosphorus during vermicomposting. Bioresource Technology, 69, 149-154.

Giller, K. E., \& Cadisch, G. (1997). Driven by nature: a sense of arrival or departure?

Giusquiani, P. L., Gigliotti, G., \& Businelli, D. (1995). Urban waste compost: effects on physical, chemical, and biochemical soil properties. Journal of Environmental Quality, 24.

Gorissen, A., \& Cotrufo, M. F. (2000). Decomposition of leaf and root tissue of three perennial grass species grown at two levels of atmospheric $\mathrm{CO} 2$ and $\mathrm{N}$ supply. Plant and Soil, 224, 75-84.

Gupta, R., \& Garg, V. K. (2008). Stabilization of primary sewage sludge during vermicomposting. Journal of Hazardous Materials, 153, 1023-1030.

Hadas, A., Kautsky, L., Goek, M., \& Erman Kara, E. (2004). Rates of decomposition of plant residues and available nitrogen in soil, related to residue composition through simulation of carbon and nitrogen turnover. Soil Biology and Biochemistry, 36, 255-266.

Hand, P., Hayes, W. A., Frankland, J. C., \& Satchell, J. E. (1988a). The vermicomposting of cow slurry. Pedobiologia, 31, 199-209. 
Hand, P., Hayes, W. A., Satchell, J. E., Frankland, J. C., Edwards, C. A., \& Neuhauser, E. F. (1988b). The vermicomposting of cow slurry. Earthworms Waste Environment Management (pp. 49-63).

Haynes, R. J. (1986). The decomposition process: mineralization, immobilization, humus formation, and degradation. Mineral nitrogen in the plant-soil system., 52-126.

Haynes, R. J., \& Naidu, R. (1998). Influence of lime, fertilizer and manure applications on soil organic matter content and soil physical conditions: a review. Nutrient Cycling in Agroecosystems, 51, 123-137.

Hendriksen, N. B. (1990). Leaf litter selection by detritivore and geophagous earthworms. Biology and Fertility of Soils, 10, 17-21.

Hulugalle, N., Lal, R., \& Terkuile, C. H. H. (1986). Amelioration of soil physical properties by Mucuna after mechanized land clearing of a tropical rainforest. Soil Science, 141, 219-224.

Huntington, T. G., Grove, J. H., \& Frye, W. W. (1985). Release and recovery of nitrogen from winter annual cover crops in no-till corn production. Communications in Soil Science and Plant Analysis, 16, 193-211.

Iannotti, D. A., Grebus, M. E., Toth, B. L., Madden, L. V., \& Hoitink, A. J. (1994). Oxygen respirometry to assess stability and maturity of composted municipal solid waste. Journal of Environmental Quality, 23, 1177-1183.

Insam, H., \& de Bertoldi, M. (2007). Microbiology of the composting process. In L. F. Diaz, M. de Bertoldi, W. Bidlingmaier \& E. Stentiford (Eds.), Waste Management Series (Vol. 8, pp. 25-48). Amsterdam, The Netherlands: Elsevier.

Jain, K., Singh, J., Chauhan, L. K. S., Murthy, R. C., \& Gupta, S. K. (2004). Modulation of flyash-induced genotoxicity in Vicia faba by vermicomposting. Ecotoxicology and Environmental Safety, 59, 89-94. 
Jane, M. F. J., Barbour, N. W., \& Weyers, S. L. (2007). Chemical composition of crop biomass impacts its decomposition. Soil Sci. Soc. Am. J, 71, 155-162.

Janzen, H. H., Beauchemin, K. A., Bruinsma, Y., Campbell, C. A., Desjardins, R. L., Ellert, B. H., \& Smith, E. G. (2003). The fate of nitrogen in agroecosystems: An illustration using Canadian estimates. Nutrient Cycling in Agroecosystems, 67, 85-102.

Jones, C. G., Lawton, J. H., \& Shachak, M. (1994). Organisms as ecosystem engineers. Oikos, 69, 373-386.

Kalantari, S., Ardalan, M. M., Alikhani, H. A., \& Shorafa, M. (2011). Comparison of Compost and Vermicompost of Yard Leaf Manure and Inorganic Fertilizer on Yield of Corn. Communications in Soil Science and Plant Analysis, 42, 123-131.

Kale, R. D., Bano, K., \& Krishnamoorthy, R. V. (1982). Potential of Perionyx excavatus for utilization of organic wastes. . Pedobiologia, 23, 419-425.

Khalil, M. I., Hossain, M. B., \& Schmidhalter, U. (2005). Carbon and nitrogen mineralization in different upland soils of the subtropics treated with organic materials. Soil Biology and Biochemistry, 37, 1507-1518.

Kowaljow, E., \& Mazzarino, J. M. (2007). Soil restoration in semiarid Patagonia: Chemical and biological response to different compost quality. Soil Biology and Biochemistry, 39, 1580-1588.

Kramer, A. W., Doane, T. A., Horwath, W. R., \& Kessel, C. (2002). Combining fertilizer and organic inputs to synchronize $\mathrm{N}$ supply in alternative cropping systems in California. Agriculture, Ecosystems \& Environment, 91, 233-243.

Kumar, K., \& Goh, K. M. (1999). Crop residues and management practices: effects on soil quality, soil nitrogen dynamics, crop yield, and nitrogen recovery. Advances in Agronomy, 68, 197-319. 
Lavelle, P., Barros, E., Blanchart, E., Brown, G., Desjardins, T., Mariani, L., \& Rossi, J. P. (2001). SOM management in the tropics: Why feeding the soil macrofauna? Nutrient Cycling in Agroecosystems, 61, 53-61.

Lavelle, P., Bignell, D., Lepage, M., Wolters, W., Roger, P., Ineson, P., Heal, O. W., \& Dhillion, S. (1997). Soil function in a changing world: the role of invertebrate ecosystem engineers. European Journal of Soil Biology, 33, 159-193.

Lazcano, C., Gómez-Brandón, M., \& Domínguez, J. (2008). Comparison of the effectiveness of composting and vermicomposting for the biological stabilization of cattle manure. Chemosphere, 72, 1013-1019.

Logsdon, G. (1994). Worldwide progress in vermicomposting: Earthworms and composting. Biocycle, 35, 63-65.

Lores, M., Gómez-Brandón, M., Pérez-Díaz, D., \& Domínguez, J. (2006). Using FAME profiles for the characterization of animal wastes and vermicomposts. Soil Biology and Biochemistry, 38, 2993-2996.

Lung, A. J., Lin, C. M., Kim, J. M., Marshall, M. R., Nordstedt, R., Thompson, N. P., \& Wei, C. I. (2001). Destruction of Escherichia coli O157: H7 and Salmonella enteritidis in cow manure composting. Journal of Food Protection 64, 1309-1314.

Maboeta, M. S., \& Rensburg, L. (2003). Vermicomposting of industrially produced woodchips and sewage sludge utilizing Eisenia fetida. Ecotoxicology and Environmental Safety, 56, 265-270.

Mackey, A. D., Syres, J. A., \& Gregg, P. E. H. (1982). Plant availability of phosphorous in superphosphate and phosphate rock as influenced by earthworms. Soil Biology and Biochemistry, 14, 281-287.

Melillo, J. M., Aber, J. D., \& Muratore, J. F. (1982). Nitrogen and lignin control of hardwood leaf litter decomposition dynamics. Ecology, 63, 621-626. 
Mitchell, A. (1997). Production of Eisenia fetida and vermicompost from feed-lot cattle manure. Soil Biology and Biochemistry, 29, 763-766.

Mitchell, A., \& Alter, D. (1993). Suppression of labile aluminium in acidic soils by the use of vermicompost extract. Communications in Soil Science and Plant Analysis, 24, 1171-1181.

Mupondi, L. T., Mnkeni, P. N. S., \& Muchaonyerwa, P. (2010). Effectiveness of combined thermophilic composting and vermicomposting on biodegradation and sanitization of mixtures of dairy manure and waste paper. African Journal of Biotechnology, 9, 4754-4763.

Ndegwa, P. M., \& Thompson, S. A. (2001). Integrating composting and vermicomposting in the treatment and bioconversion of biosolids. Bioresource Technology, 76, 107-112.

Newbould, P. (1989). The use of nitrogen fertilizer in agriculture. Where do we go practically and ecologically? . Plant and Soil, 115, 297-311.

Ouedraogo, E., Mando, A., \& Brussaard, L. (2006). Soil macrofauna affect crop nitrogen andáwater use efficiencies in a semi-arid West Africa. European Journal of Soil Biology, $42,275-277$.

Padmavathiamma, P. K., Li, L. Y., \& Kumari, U. R. (2008). An experimental study of vermi-biowaste composting for agricultural soil improvement. [10.1016/j.biortech.2007.04.028]. Bioresource Technology, 99, 1672-1681.

Papadimitriou, E. K., \& Balis, C. (1996.). Comparative study of parameters to evaluate and monitor the rate of a composting process. Compost Science \& Utilization, 4, 52-61.

Pattnaik, S., \& Reddy, M. V. (2010). Nutrient status of vermicompost of urban green waste processed by three earthworm species-Eisenia fetida, Eudrilus eugeniae, and Perionyx excavatus. Applied and Environmental Soil Science, 2010, 1-13. 
Peoples, M. B., Boyer, E. W., Goulding, K. W. T., Heffer, P., Ochwoh, V. A., Vanlauwe, B., Wood, S., Yagi, K., \& Van Cleemput, O. (2004). Pathways of nitrogen loss and their impacts on human health and the environment. In A. R. Mosier, J. K. Syers \& J. R. Freney (Eds.), Agriculture and the nitrogen cycle: assessing the impact of fertilizer use on food production and the environment (SCOPE) (pp. 53-69). Covelov, California, USA: Islan Press.

Ranells, N. N., \& Wagger, M. G. (1996). Nitrogen release from grass and legume cover crop monocultures and bicultures. Agronomy Journal, 88, 777-782.

Rezig, A. M. R., Elhadi, E. A., \& Mubarak, A. R. (2012). Effect of incorporation of some wastes on a wheat-guar rotation system on soil physical and chemical properties. International Journal of Recycling of Organic Waste in Agriculture, 1, 1-15.

Riggle, D., \& Holmes, H. (1994). New horizons for commercial vermiculture. BioCiyclc, $10,58-67$.

Ryckeboer, J., Mergaert, J., Vaes, K., Klammer, S., De Clercq, D., Coosemans, J., Insam, H., \& Swings, J. (2003). A survey of bacteria and fungi occurring during composting and self-heating processes. Annals of microbiology, 53, 349-410.

Sánchez, P. A., \& Leakey, R. R. B. (1997). Land use transformation in Africa: three determinants for balancing food security with natural resource utilization. Developments in Crop Science, 25, 19-27.

Shoko, M. D., Tagwira, F., \& Zhou, M. (2007). The potential of reducing nitrogen fertilizer rates using a soyabean-sugarcane production system in the South Eastern Lowveld of Zimbabwe. African Journal of Agricultural Research, 2, 475-480.

Short, J. C. P., Frederickson, J., \& Morris, R. M. (1999). Evaluation of traditional windrow-composting and vermicomposting for the stabilization of waste paper sludge (WPS). Pedobiologia, 43, 735-743. 
Sikora, L. J., \& Enkiri, N. K. (1999). Growth of tall fescue in compost/fertilizer blends. Soil Science, 164, 62-62.

Six, J., Feller, C., Denef, K., Ogle, S. M., Sa, J. C. M., \& Albrecht, A. (2002). Soil organic matter, biota and aggregation in temperate and tropical soils-Effects of notillage. Agronomie, 22, 755-775.

Smith, J. L., Papendick, R. I., Bezdicek, D. F., Lynch, J. M., \& Metting Jr, F. B. (1992). Soil organic matter dynamics and crop residue management. Soil microbial ecology: applications in agricultural and environmental management., 65-94.

Stevenson, F. J. (1994). Humus chemistry: genesis, composition, reactions: John Wiley \& Sons Inc.

Stute, J. K., \& Posner, J. L. (1995). Synchrony between legume nitrogen release and corn demand in the upper Midwest. Agronomy Journal, 87, 1063-1069.

Subler, S., Edwards, C., \& Metzger, J. (1998). Comparing vermicomposts and composts. BioCycle, 7, 63-66.

Sundaravadivel, S., \& Ismail, S. (1995). Efficacy of a biological filter unit in the treatment of distillery effluents. Journal of Ecotoxicology \& Environmental Monitoring, $5,125-129$.

Suthar, S. (2006). Potential utilization of guar gum industrial waste in vermicompost production. Bioresource Technology, 97, 2474-2477.

Suthar, S. (2007). Vermicomposting potential of Perionyx sansibaricus (Perrier) in different waste materials. Bioresource Technology, 98, 1231-1237.

Swift, M. J., Heal, O. W., \& Anderson, J. M. (1979). Decomposition in terrestrial ecosystems. Berkeley: University of California Press. 
Swift, M. J., Izac, A., \& van Noordwijk, M. (2004). Biodiversity and ecosystem services in agricultural landscapes-are we asking the right questions? Agriculture, Ecosystems \& Environment, 104, 113-134.

Syres, J. K., \& Springett, J. A. (1984). Earthworms and soil fertility. Plant and Soil, 76, 93-104.

Tejada, M., \& Gonzalez, J. L. (2003). Application of a byproduct of the two-step olive oil mill process on rice yield. Agrochimica, 47, 94-102.

Tejada, M., \& Gonzalez, J. L. (2004). Effects of application of a by-product of the twostep olive oil mill process on maize yield. Agronomy Journal, 96, 692-692.

Tian, G., Kang, B. T., \& Brussaard, L. (1992). Biological effects of plant residues with contrasting chemical compositions under humid tropical conditions-Decomposition and nutrient release. Soil Biology and Biochemistry, 24, 1051-1060.

Tilman, D., Fargione, J., Wolff, B., D'Antonio, C., Dobson, A., Howarth, R., Schindler, D., Schlesinger, W. H., Simberloff, D., \& Swackhamer, D. (2001). Forecasting agriculturally driven global environmental change. Science, 292, 281-281.

Tisdale, S. L., Havlin, J. L., Beaton, J. D., \& Nelson, W. L. (2005). Soil fertility and fertilizers: An introduction to nutrient management, 6th edn. New Jersey: Pearson Prentice Hall

Tognetti, C., Laos, F., Mazzarino, M. J., \& Hernandez, M. T. (2005). Composting versus vermicomposting: a comparison of end product quality. Compost Science \& Utilization, $13,6-13$.

Tomati, U., Grappelli, A., Galli, E., \& Rossi, W. (1983). Fertilizers from vermiculture as an option for organic wastes recovery. Agrochimica, 27, 244-251.

Trinsoutrot, I., Nicolardot, B., Justes, E., \& Recous, S. (2000). Decomposition in the field of residues of oilseed rape grown at two levels of nitrogen fertilisation. Effects on the 
dynamics of soil mineral nitrogen between successive crops. Nutrient Cycling in Agroecosystems, 56, 125-137.

Tu, C., Ristaino, J. B., \& Hu, S. (2006). Soil microbial biomass and activity in organic tomato farming systems: Effects of organic inputs and straw mulching. Soil Biology and Biochemistry, 38, 247-255.

Venterea, R. T., \& Rolston, D. E. (2000). Nitric and nitrous oxide emissions following fertilizer application to agricultural soil: Biotic and abiotic mechanisms and kinetics. Journal of geophysical research, 105, 15117-15115.

Villar, M. C., Beloso, M. C., Acea, M. J., Cabaneiro, A., González-Prieto, S. J., Carballas, M., Díaz-Raviña, M., \& Carballas, T. (1993). Physical and chemical characterization of four composted urban refuses. Bioresource Technology, 45, 105-113.

Vinceslas-Akpa, M., \& Loquet, M. (1997). Organic matter translocations in lignocellulosic waste products composted or vermicomposted (Eisenia fetida andrei): Chemical analysis and 13C CPMAS NMR spectroscopy. Soil Biology and Biochemistry, $29,751-758$.

Vitousek, P. M., Aber, J. D., Howarth, R. W., Likens, G. E., Matson, P. A., Schindler, D. W., Schlesinger, W. H., \& Tilman, D. G. (1997). Human alteration of the global nitrogen cycle: sources and consequences. Ecological Applications, 7, 737-750.

Watmann, C. S., \& Kayuki, K. C. (2001). Plants materials for soil fertility management in subhumid tropical area. Agronomy Journal, 93, 925-935.

Wilhelm, W. W., Johnson, J. M. F., Hatfield, J. L., Voorhees, W. B., \& Linden, D. R. (2004). Crop and soil productivity response to corn residue removal. Agronomy Journal, 96, 1-17.

Witkamp, M., \& Ausmus, B. S. (1976). The chemical analysis composition and nutrient transfer in forest ecosystems. In The Role of Terrestrial and Aquatic Organisms in decomposition. Processes in de-King J. G. C. and Heath G. W. (1967). 
Wu, L., Ma, L. Q., \& Martinez, G. A. (2000). Comparison of methods for evaluating stability and maturity of biosolids compost. Journal of Environmental Quality, 29, 424429.

Zhang, W. J., \& Zhang, X. Y. (2007). A forecast analysis on fertilizers consumption worldwide. Environmental Monitoring and Assessment, 133, 427-434.

Zmora-Nahum, S., Markovitch, O., Tarchitzky, J., \& Chen, Y. (2005). Dissolved organic carbon (DOC) as a parameter of compost maturity. Soil Biology and Biochemistry, 37, 2109-2116. 


\section{Effect of compost and vermicompost on soil organic matter (SOM) and crop nutrients uptake}

\subsection{Soil Organic matter (SOM)}

Organic matter (OM) is a key component in the creation and maintenance of soil high quality (Gregorich et al., 1994; Larson \& Pierce, 1994) and of environmental quality (Smith et al., 2000). Soil quality has been defined as the capacity of the soil to function effectively, both in the present and in the future (Doran \& Parkin, 1994). Effective functioning of soil varies; depending on the required end use of the soil. However, it is generally accepted that it is better to have more SOM, which serves as a repository of nutrients (particularly nitrogen $(\mathrm{N})$, phosphorus $(\mathrm{P})$, sulfur $(\mathrm{S})$ and other micronutrients) and, during its turnover, contributes to fertility at times and in locations in the soil profile that are difficult to access with inorganic nutrient fertilizers.

When soils are properly managed, SOM contributes to a favorable soil structure and increases the cation exchange capacity, particularly in coarse-textured soils, and increases the soil's available water-holding capacity (Hudson, 1994; Liu et al., 2003). Soil organic matter enhances aggregation, which in turn improves soil tilth, the infiltration of water and the exchange of gases between soil and atmosphere. Soil biota are important soil constituents who are usually strongly associated with components of soil organic matter. Soil microbial biomass and activities are largely enhanced with presence of organic matter as a source for growth when other physiochemical factors are optimum (Aryantha et al., 2000; Morris et al., 2004).

The microbial biomass of a soil is mainly made up of bacteria and fungi as well as protozoa, and algae. Besides microorganisms, the soil is also the habitat for larger organisms such as earthworms, springtails and mites. These different macrofauna play an important role in the functioning of the soil ecosystem, especially through regulating the activities of microbial communities and associated processes involved with the storing and cycling of nutrients and energy (Alabouvette et al., 2004; Carter et al., 1999). Emerging the concept of soil quality includes also soil health concept (Van Bruggen \& Semenov, 2000). A healthy soil is not only a fertile soil, but also the best biotic environment enabling the plant to resist pathogens. 
From economic point of view, increased levels of SOM can affect the economics of farming practices in ways other than directly influencing production. For example, farmers often report a noticeable decrease in power requirements for tillage machinery after some years of manure application or conservation tillage practices. This is usually attributed to the build-up of SOM, and some research has corroborated this, for instance, McLaughlin et al. (2002) measured mouldboard draught and tractor fuel consumption during a couple of years on unamended plots or $t$ received different levels of inorganic fertilizers and manures; after eight years of application, concluded that, plots receiving manure amendments reduced draught and tractor fuel consumption than those receiving inorganic fertilizers. Their results imply potential savings in tillage and lower fuel costs.

Regarding the environmental health, SOM can be a major source or sink of atmospheric carbon and may be able to mitigate the greenhouse effect through appropriate soil management (Lal, 2001). In order to sustain soil health and productivity, proper management of $\mathrm{OM}$ is crucially needed considering differences in soils, climate conditions and cultural practices.

The organic matter content in soil can range from less than $1 \%$ in coarse textured or highly oxidized soils to nearly $100 \%$ in wetland bogs. Farm soils have concentrations of soil OM that generally ranges between 1 and 10\% (Dick \& Gregorich, 2004). The chemical composition of SOM can vary depending on when and where soil is sampled but typically contains about $50 \% \mathrm{C}, 40 \% \mathrm{O}_{2}, 5 \% \mathrm{H}, 4 \% \mathrm{~N}$ and $1 \% \mathrm{~S}$. Most of the other mineral nutrients are also associated in some way with OM; some as exchangeable cations and anions, as cation bridges or simply adsorbed on the surface of organo-mineral particles (Dick \& Gregorich, 2004). 
Studies indicated that there is remarkable similarity in the distribution of carbon forms in soils under a wide range of climate, land use, cropping practice and fertilizer amendments (Anderson et al., 1981; Mahieu et al., 1999). Changes in the quantity of SOM and the equilibrium of their level depend on the interaction of five factors: climate, landscape, soil texture, inputs and disturbance (Allison, 1973; Dick \& Gregorich, 2004). Changes in SOM content and its fractions can greatly affect soil fertility and crop production. Soil OM includes active and inactive organic carbon (Blair et al., 1995). Active organic carbon is considered to be the most active component of SOM under a certain time-space condition; it can be easily oxidized and degraded and has a significant effect on plants and soil microorganisms (Shen et al., 1999).

\subsection{Soil organic matter in arid and semi-arid regions}

By definition, arid and semiarid soils are short of water, and crop growth; microbiological activity, and biochemical reactions depend on water and temperature. Most biochemical reactions occur in the liquid phase, and all nutrients for microorganisms and plants must dissolve in water before they can be assimilated (Newbould, 1989) therefore, soils of arid and semi-arid regions are characterized low organic matter and limited availability of plant nutrients. In particular, $\mathrm{P}$ and $\mathrm{N}$ are major bottlenecks to agricultural productivity (Charley \& West, 1975; Schlecht et al., 2006; West \& Skujinš, 1978). Additionally, the region faced serious problems concerning land scarcity coupled with intensive cultivation without adequate nutrient inputs and consequently soil erosion (Govers et al., 2004; Karlen et al., 2004) and rapid decrease per capita land area and water resources (Lal, 2000).

The majority of the population in these regions is rural and relies on subsistence agriculture. Therefore, soil must be properly managed to overcome losses of nutrients. Hence, developing low cost technologies for retaining soil health and to increase crop production has been the core of several researchers in the region. The contribution of locally available resources for correcting nutrients deficiency has been given much attention (Nziguheba, 2007). Possible management practices could be recycling of organic residues; crop residues and different materials are preferred to be implemented 
under controlled conditions that could be applied to the soil to shorten time required for nutrient release and synchronized with crop demand.

\subsection{Sustainability of soil organic matter}

Sustainability of SOM is always associated with soil quality to sustain plant and animal productivity, maintain or enhance water and air quality, and support human health and habitation (Glanz, 1995; Karlen et al., 1997). Awareness of the environmental aspects of soil quality and crop production has led to the interest in crop residues, green manure and other organic wastes as sources of SOM and nutrients for plants. Soil organic matter sustainability is achieved via continuous application and proper management of the organic wastes.

Crop residues of common cultivated crops are defined in general as parts of the plants left in the field after crop has been harvested and thrashed or left after pastures are grazed; these materials are considered as important resources not only as a source of significant nutrients for crop production but also has diverse effects on soil quality parameters (Kumar \& Goh, 1999).

\subsection{Role of compost and vermicompost in sustainable farming}

Because SOM strongly soil quality and productivity, it is suggested to be the heart to sustaining agricultural productivity (Reeves, 1997). Proper disposal of these wastes by recycling can supply plant nutrients and improve soil physical conditions and environmental quality (Bhardwaj, 1995; Mishra et al., 1989). The decomposition of crop residues is a microbial-mediated progressive breakdown of organic materials with ultimate end product carbon and nutrients released into the biological circulation in the ecosystem at both local and global scale.

Integration of various processes is a necessity in order to meet high levels of waste conversion and reduce reliance on land disposal. The widest spread and relatively simple

and cost effective methods of treating organic wastes are composting and vermicomposting, which have been utilized to produce materials rich in plant nutrients. 


\subsubsection{Composting}

Composting is an effective useful way of disposal and transforming organic wastes into a stable valuable organic matter for use as an organic amendment for soils (Vinceslas-Akpa \& Loquet, 1997). This process avoids the rapid release of nutrients from fresh residues and, consequently, reduces negative environmental impacts (Cooperband et al., 2000). The beneficial effects of composted amendments on the chemical, physical and biological properties of soils have been well documented, and are closely linked to soil conditions, application rates and frequency, and organic matter quality (Gabrielle et al., 2004; Giusquiani et al., 1995; Laos et al., 2000). Compost is defined as the end-product of a biological decomposition and stabilization of organic substrates under conditions that allow high temperatures as a result of biologically produced heat (Fracchia et al., 2006). Composts with high contents of labile organic matter enhance biological activity and nutrient release, whereas recalcitrant or slow decomposable organic matter improves water and nutrient storage, and soil structure, increasing soil resistance to erosion.

\subsubsection{Vermicomposting}

Soil fauna are increasingly recognized to have a significant role in soil function and processes affecting nutrient availability for microorganism and crop performance (Ouedraogo et al., 2006); this beneficial effect can be optimized with use of organic resources with contrasting qualities. Soil macroinvertebrates such as earthworms and termites; enhance the activity of other soil microorganisms by modifying their physicochemical environment (Blanchart et al., 1999; Brown et al., 2000). The role of earthworms in improving soil fertility is well-known and has been used for many years worldwide (Golueke, 1973; Golueke et al., 1980; Kapoor \& Bansal, 2000) and their remarkable effects on control of soil microorganism biomass, diversity and activity have recognized (Doube \& Brown, 1998).

By aeration and bioturbation, by their excreta and qualitative or quantitative influence upon the microflora, earthworms help to accelerate the transformation of organic matter to a nearly stable humus-like material (Elvira et al., 1996; Elvira et al., 1998; Reinecke et al., 1992) and they considerably accelerate mineralization during gut transit (Lavelle et al., 2001). The produced finished products (vermicompost) are fine particulate structure, 
contain nutrients in forms that are readily available for plant uptake, rich in microbial activity and plant growth regulators, and fortified with pest repellence attributes as well (Atiyeh et al., 2000a; Nagavallemma et al., 2006; Orozco et al., 1996). The released assimilable nutrients and number of other interactions often stimulate plant growth, improves quality and yield of different crops (Brussaard, 1998). Regarding amelioration of the soil, physical properties with vermicomposts, limited studies indicate that vermicompost increases macropore space and improves the air-water relationships in the soil which favorably affects plant growth (Marinari et al., 2000). Due to the abovementioned specifications, vermicomposts should have a great potential in the horticultural and agricultural industries as media for plant growth (Atiyeh et al., 2000c).

\subsection{Factors affecting organic matter decomposition}

\subsubsection{General mechanisms}

The breakdown of organic matter during the composting process is dependent on several factors working together. These include moisture, temperature, $\mathrm{O}_{2}$ and a balance of $\mathrm{N}$ and C. Microorganisms living within the organic wastes consume the readily available $\mathrm{C}$.

An important factor associated with microbial activities is that availability and function of the enzymatic makeup of the individual microbe. Thus, certain groups of microbes have an enzymatic complex that permits them to attack, degrade, and utilize the organic matter as a source of nutrients. Production of these enzymes depends on the nature of the available organic substrate (easily decomposable, intermediate and complex) (Diaz \& Savage, 2007). As organic carbon is metabolized, temperature in the pile increases gradually and $\mathrm{CO}_{2}$ released. Immediately thereafter, the temperature rises almost exponentially with time until it begins to plateau at about $65^{\circ}$ or $70^{\circ} \mathrm{C}$ (Ogunwande \& Osunade, 2011). As a result, the pile is populated with thermophilic mircoorganisms (Xiao et al., 2011). This period depends on the nature of the organic materials and system used, and then begins to decline gradually until the ambient temperature is reached allowing for colonization of fungi that slowly consumes most of the recalcitrant $\mathrm{C}$ (lignin and cellulose) (Godden et al., 1992; Tuomela et al., 2000). 
It may be assumed that by the time the temperature has descended to ambient or a few degrees above, the more biologically unstable components in the wastes have been stabilized, and therefore, the material is sufficiently composted for storage or for utilization (Diaz \& Savage, 2007).

For vermicomposting, temperature is a factor of primary importance for earthworms because it determines individual earthworm metabolic rates. Vermicomposting is mainly a non-thermophilic process (Elvira et al., 1996; Elvira et al., 1998) and the range of temperatures within which most earthworms can function is narrow, with upper lethal temperatures rather low $\left(25^{\circ}-35^{\circ} \mathrm{C}\right)$ and optimum temperatures typically in the range $10^{\circ}$ to $20^{\circ} \mathrm{C}$ for cool temperate species and $20^{\circ}$ to $30^{\circ} \mathrm{C}$ for tropical and subtropical species (Edwards \& Bohlen, 1996; Lee, 1985). During organic waste's decomposition, the range of optimum temperature can be above mentioned but less than $35^{\circ} \mathrm{C}$ (Edwards, 2004b).

During ingestion, earthworms fragment the waste substrate, accelerate the rates of decomposition of the organic matter, alter the physical and chemical properties of the material, leading to an effect similar to composting in which the unstable organic matter is oxidized and stabilized aerobically (Albanell et al., 1988; Atiyeh et al., 2000a; Orozco et al., 1996). The end product, which is obtained as a result of biological transformations, is very different from the initial material, mainly because of the increased decomposition and humification (Atiyeh et al., 2002a). 


\subsubsection{Aeration and moisture}

In composting, one of the main factors ensures continuous metabolism of organic substrates is the provision of oxygen to the composting mass. The air contained in the interspaces of the composting mass, during the microbial activity, varies in composition. The $\mathrm{CO}_{2}$ content gradually increases, and the $\mathrm{O}_{2}$ level falls. Oxygen concentration varies from 15 to $20 \%$ and $\mathrm{CO}_{2}$ from 0.5 to 5\% (MacGregor et al., 1981). When $\mathrm{O}_{2}$ falls below these levels, anaerobic microbial populations surpass aerobic ones. As a result, fermentation and anaerobic respiration processes take over. It is, therefore, important to supply microorganisms with a constant $\mathrm{O}_{2}$ supply via ventilation or periodic pile turning to maintain their metabolic activities unaltered (Finstein et al., 1983; Finstein et al., 1999).

\subsection{3. $\underline{\mathrm{pH}}$}

Generally, organic matter with a wide range of $\mathrm{pH}$ (from 3 - 11) can be composted (de Bertoldi et al., 1985). The acidity of compost materials is due to the presence of shortchain organic acids that are generated during the initial phase of batch composting (Nakasaki et al., 1993; Sundberg et al., 2004) and this may reduce the pH, inhibits microbiological activity, and sometimes severely hampers progress of the composting reaction (Beck-Friis et al., 2001). Therefore, inhibiting the adverse effect of organic acids, i.e., controlling $\mathrm{pH}$ during the initial composting phase, is the primary issue to be resolved. However, the optimum range is between 5.5 and 8.0. Whereas bacteria prefer a nearly neutral $\mathrm{pH}$, fungi develop better in a fairly acidic environment.

Generally, the $\mathrm{pH}$ begins to drop at the beginning of the process (i.e., down to 5.0) as a consequence of the activity of microorganisms that break down complex carbonaceous material to organic acids. When this acidification phase is over and the intermediate metabolites are completely mineralized, the $\mathrm{pH}$ tends to increase and at the end of the process is around $8.0-8.5$.

High $\mathrm{pH}$ values in the starting material in association with high temperatures can cause a loss of $\mathrm{N}$ through the volatilization of ammonia that may have an adverse effect on the activities of microorganisms (Nakasaki et al., 1993; Sundberg et al., 2004). 
With regard to vermicomposting, it has been demonstrated that earthworms are very sensitive to the $\mathrm{pH}$, so it is not surprising that soil $\mathrm{pH}$ is sometimes a factor that limits the species, numbers, and distribution of earthworms, which live any particular soil (Edwards \& Bohlen, 1996). Several workers have stated that most species of earthworms prefer a neutral to slightly alkaline $\mathrm{pH}$, and many species can tolerate a wide range of $\mathrm{pH}$. The $\mathrm{pH}$ of the vermicomposting is a substrate dependent (Ndegwa et al., 2000) hence, earthworms do not normally like acidic wastes, and therefore, these wastes should be pretreated (Nair et al., 2006).

It has been reported that earthworm casts are usually are neutral (around 7.0) (Nagavallemma et al., 2006); one possible explanation suggested for this is that earthworms neutralize materials as it passes through their guts, by secretions of the calciferous glands. A more probable explanation is that the materials are neutralized by secretions from the intestine and by excretions of ammonia, or that it is a combination of the two (Edwards \& Bohlen, 1996).

\subsubsection{Crop residue factors}

Crop residues' decomposition processes are controlled by three main factors; kind of plant residues, residues management factors and edaphic factors. Many of these factors have interactive effects (Kumar \& Goh, 1999). Some of the most important physical characteristics of the substrate are primarily related to particle size and moisture content of the material. Some of the pertinent chemical characteristics include those associated with molecular size, complexity and nature, as well as elemental makeup of the molecules (Diaz \& Savage, 2007). The complexity and nature of the molecular structure of the substrate are particularly important because these characteristics define the assimilability of the nutrients by the various microorganisms.

Plants contain different proportions of cellulose, hemicellulose, lignin, protein, and soluble substances (Paul \& Clark, 1989); plants also contain cutin (Gallardo \& Merino, 1993), polyphenols (Tian et al., 1995a), and silica (Goering \& Van Soest, 1975). The rate of organic matter breakdown depends on the relative proportions of each of these fractions (Stout et al., 1981). It has long been recognized that the fractional loss rate 
declines with time (Andrén et al., 1990; Bending et al., 1998), and this reduction with time reflects the decline in the quality of the remaining substrate. Therefore, it is generally accepted that residues with a wide $\mathrm{C}: \mathrm{N}$ ratio decompose more slowly than those with a narrow one, and plant residues with high $\mathrm{N}$ content show high decomposition rates and nutrient release (Douglas \& Rickman, 1992; Janzen \& Kucey, 1988).

Lignin is known to be a recalcitrant substance, highly resistant to microbial decomposition (Melillo et al., 1982) and only relatively few microorganisms can degrade lignin, and these are exclusively aerobic (Jenkinson et al., 1987); therefore, its inhibitory effect in the decomposition process has been reported in several studies (Berendse et al., 1987; Fox et al., 1990; Giller \& Cadisch, 1997).

Polyphenols are like lignin; they have adverse effects on organic matter decomposition and nutrient release; they bind to protein and form complexes resistant to decomposition, and can also bind to organic $\mathrm{N}$ compounds making it unavailable (Northup et al., 1995; Valus \& Jones, 1973). The importance of polyphenols in residue decomposition and the mineralization process has been debated frequently, and different ratios with other crop residue factors have been generated and correlated with residue decomposition and nutrient release (Haynes, 1986; Palm \& Sanchez, 1991; Vigil \& Kissel, 1991).

\subsection{Crop responses to vermicompost}

Several researchers have examined the physical and chemical properties of vermicomposts. Edwards and Burrows (1988) reported that vermicomposts are finely divided peat-like materials with high porosity, aeration, drainage, and water-holding capacity. They have a large surface area, providing strong capacity to hold and retain nutrients (Shi-Wei \& Fu-Zhen, 1991). Compared to their parent materials, vermicomposts have less soluble salts, greater cation exchange capacity, and increased total humic acid contents (Albanell et al., 1988). Vermicomposts contain nutrients in forms that are taken up by the plants readily, such as nitrates, exchangeable $\mathrm{P}$, and soluble K, Ca, and Mg (Edwards \& Burrows, 1988; Orozco et al., 1996). Vermicomposts have also been reported to contain biologically active substances such as plant growth 
regulators (Doube et al., 1997; Grapeelli et al., 1987; Krishnamoorthy \& Vajranabhaiah, 1986).

In a field trial, Mba (1996), tested the bio-fertilizer value of the vermicomposts produced from three different agricultural wastes; and reported that crop aerial biomass significantly increased compared to untreated field plots.

The possible mechanisms by which vermicomposts produce these growth enhancement effects in addition to the nutrients' availability, is the production of significant quantities of plant growth regulators by the promoted microorganisms, due to the presence of earthworms (Edwards, 1998b; Krishnamoorthy \& Vajranabhaiah, 1986; Tomati et al., 1988). It has been also shown that the incidence of plant diseases can be limited by vermicomposts (Nakamura, 1996; Szczech et al., 1993).

\subsection{Crop responses to compost}

Application of composts has been widely used for millennia as a source of fertility; results in the literature are tremendous and demonstrating different effects of compost on crop growth and nutrients uptake. Compost has been found to improve soil structure, organic matter content and nutrient supply to plants and thus may reduce the input of mineral fertilizers in conventional agriculture and provide a useful nutrient source in organic farming; respectively (Giusquiani et al., 1995; Parkinson et al., 1999).

Long term application of compost significantly increased moisture-holding capacity, decreased bulk density and compression strength of the soil. However, heavy application rates of compost with adverse effects has also been reported in terms of high concentrations of toxic metals, increase plant disease incidence when coupled with improper application of necessary chemicals to control plant pests and diseases (Hoitink \& Boehm, 1999; Tuitert et al., 1998) or phytotoxicity due to too high soluble salts (Madejón et al., 2001). In fact, compost application can affect the suppression of disease in cropping systems in positive, neutral, or even negative ways.

Because of their different production processes, compost and vermicompost might exhibit distinctive physical and chemical features, which might influence soil properties and plant growth in diverse ways. Generally, the final product of vermicomposting is 
more uniform in size with a characteristic of earthy appearance while the resulting material after composting is normally more heterogeneous (Ndegwa \& Thompson, 2001; Tognetti et al., 2005). Nevertheless, the most remarkable differences among them are related to their biological characteristics. Both processes strongly condition the biological properties of the finished products resulting in important differences in the bacterial community composition and functional diversity (Vivas et al., 2009) and fungal abundance (Lazcano et al., 2008) even when the same organic waste is used as a raw material. Considering that most of the beneficial effects of compost and vermicompost have been related to their biological properties (Atiyeh et al., 1999; De Brito et al., 1995), these differences could determine rather diverse effects in soil characteristics and plant growth (Chaoui et al., 2003). Further, parent waste and application rates or the substitution doses assayed are also possible causes for such diverse effects (Lazcano et al., 2009). In this sense, general statements are used for such comparisons as encapsulated in the following table (Table 3.1). 
Table 3.1: General differences between the effect of compost and vermicompost applications

\begin{tabular}{|c|c|c|c|}
\hline Criteria & Compost & Vermicompost & Reference \\
\hline Bulk density & decrease & $\begin{array}{l}\text { significant } \\
\text { reduction }\end{array}$ & (Hashemimajd et al., 2004) \\
\hline $\begin{array}{l}\text { Porosity and } \\
\text { aeration }\end{array}$ & improve & $\begin{array}{l}\text { the peat-like } \\
\text { material with high } \\
\text { porosity allows } \\
\text { good aeration and } \\
\text { drainage }\end{array}$ & $\begin{array}{l}\text { (Chaoui, et al., 2003; } \\
\text { Hashemimajd, et al., 2004; } \\
\text { Haynes \& Swift, 2006) }\end{array}$ \\
\hline $\begin{array}{l}\text { Water- holding } \\
\text { capacity }\end{array}$ & improve & significant improve & $\begin{array}{l}\text { (Hashemimajd, et al., 2004; } \\
\text { Hernando et al., 1989; Jouquet et } \\
\text { al., 2011) }\end{array}$ \\
\hline Soil structure & improve & effective improve & (Hernando, et al., 1989) \\
\hline $\begin{array}{l}\text { Aggregate } \\
\text { stability }\end{array}$ & increase & marked increase & $\begin{array}{l}\text { (Ansari, 2008; Haynes \& Swift, } \\
\text { 2006; Hernando, et al., 1989) }\end{array}$ \\
\hline $\begin{array}{l}\text { Soil organic } \\
\text { matter }\end{array}$ & increase & $\begin{array}{l}\text { the humus-like } \\
\text { materials } \\
\text { significantly } \\
\text { increases the } \\
\text { content }\end{array}$ & $\begin{array}{l}\text { (Chaoui, et al., 2003; Lazcano, et } \\
\text { al., 2009) }\end{array}$ \\
\hline $\begin{array}{l}\text { Nutrient } \\
\text { mineralization } \\
\text { rate }\end{array}$ & & $\begin{array}{l}\text { slow mineralization } \\
\text { rate and more } \\
\text { synchronized with } \\
\text { plant requirements }\end{array}$ & $\begin{array}{l}\text { (Chaoui, et al., 2003; Cox, 1993; } \\
\text { Suthar, 2009) }\end{array}$ \\
\hline $\begin{array}{l}\text { Microbial } \\
\text { biomass }\end{array}$ & & $\begin{array}{l}\text { effective in } \\
\text { enhancing the } \\
\text { population and } \\
\text { activity of some } \\
\text { microorganisms }\end{array}$ & $\begin{array}{l}\text { (Chaoui, et al., 2003; Kale et al., } \\
\text { 1992; Suthar, 2009) }\end{array}$ \\
\hline $\begin{array}{l}\text { Ionic strength } \\
\text { and other salinity } \\
\text { indicators }\end{array}$ & high & $\begin{array}{l}\text { much lower and } \\
\text { mitigate soil } \\
\text { salinity }\end{array}$ & $\begin{array}{l}\text { (Chaoui, et al., 2003; Garcia- } \\
\text { Gomez et al., 2002; Garcia et al., } \\
\text { 1995) }\end{array}$ \\
\hline $\mathrm{pH}$ & $\begin{array}{l}\text { the alkaline } \mathrm{pH} \\
\text { of the product } \\
\text { raises the } \mathrm{pH} \text { of } \\
\text { the soil or the } \\
\text { potting media }\end{array}$ & has neutral $\mathrm{pH}$ & $\begin{array}{l}\text { (Atiyeh et al., 2000; Gallardo- } \\
\text { Lara \& Nogales, 1987; } \\
\text { Hernando, et al., 1989) }\end{array}$ \\
\hline Plant response & & much better & $\begin{array}{l}\text { (Edwards et al., 1985; Suthar, } \\
\text { 2009) }\end{array}$ \\
\hline
\end{tabular}




\subsection{References}

Alabouvette, C., Backhouse, D., Steinberg, C., Donovan, N. J., Edel-Hermann, V., Burgess, L. W., Schjnning, P., Elmholt, S., \& Christensen, B. T. (2004). Microbial diversity in soil-effects on crop health. In P. Schjønning, S. Elmholt \& B. T. Christensen (Eds.), Managing Soil Quality. Challenges in Modern Agriculture (pp. 121-138). Wallingford, UK: CAB International.

Albanell, E., Plaixats, J., \& Cabrero, T. (1988). Chemical changes during vermicomposting (Eisenia fetida) of sheep manure mixed with cotton industrial wastes. Biology and Fertility of Soils, 6, 266-269.

Albiach, R., Canet, R., Pomares, F., \& Ingelmo, F. (2001). Organic matter components and aggregate stability after the application of different amendments to a horticultural soil. Bioresource Technology, 76, 125-129.

Allison, F. E. (1973). Soil organic matter and its role in crop production: Elsevier Science \& Technology.

Anderson, D. W., Saggar, S., Bettany, J. R., \& Stewart, J. W. B. (1981). Particle Size Fractions and Their Use in Studies of Soil Organic Matter: I. The Nature and Distribution of Forms of Carbon, Nitrogen, and Sulfur1. Soil Sci. Soc. Am. J., 45, 767-772.

Andrén, O., Lindberg, T., Boström, U., Clarholm, M., Hansson, A. C., Johansson, G., Lagerlöf, J., Paustian, K., Persson, J., Pettersson, R., \& others. (1990). Organic carbon and nitrogen flows. Ecological Bulletins, 85-126.

Ansari, A. A. (2008). Effect of vermicompost on the productivity of potato (Solanum tuberosum) spinach (Spinacia oleracea) and turnip (Brassica campestris). World Journal of Agricultural Sciences, 4, 333-336.

Aryantha, I. P., Cross, R., \& Guest, D. I. (2000). Suppression of Phytophthora cinnamomi in potting mixes amended with uncomposted and composted animal manures. Phytopathology, 90, 775-782. 
Atiyeh, R., Subler, S., Edwards, C., \& Metzger, J. (1999). Growth of tomato plants in horticultural potting media amended with vermicompost. Pedobiologia, 43, 724-728.

Atiyeh, R. M., Arancon, N., Edwards, C. A., \& Metzger, J. D. (2000a). Influence of earthworm-processed pig manure on the growth and yield of greenhouse tomatoes. Bioresource Technology, 75, 175-180.

Atiyeh, R. M., Arancon, N. Q., Edwards, C. A., \& Metzger, J. D. (2002a). The influence of earthworm-processed pig manure on the growth and productivity of marigolds. Bioresource Technology, 81, 103-108.

Atiyeh, R. M., Dominguez, J., Subler, S., \& Edwards, C. A. (2000b). Changes in biochemical properties of cow manure during processing by earthworms (Eisenia andrei, Bouché) and the effects on seedling growth. Pedobiologia, 44, 709-724.

Atiyeh, R. M., Edwards, C. A., Subler, S., \& Metzger, J. D. (2000c). Earthwormprocessed organic wastes as components of horticultural potting media for growing marigold and vegetable seedlings. Compost Science \& Utilization, 8, 215-223.

Atiyeh, R. M., Lee, S., Edwards, C. A., Arancon, N. Q., \& Metzger, J. D. (2002b). The influence of humic acids derived from earthworm-processed organic wastes on plant growth. Bioresource Technology, 84, 7-14.

Atiyeh, R. M., Subler, S., Edwards, C. A., Bachman, G., Metzger, J. D., \& Shuster, W. (2000d). Effects of vermicomposts and composts on plant growth in horticultural container media and soil. Pedobiologia, 44, 579-590.

Bailey, K. L., \& Lazarovits, G. (2003). Suppressing soil-borne diseases with residue management and organic amendments. Soil and Tillage Research, 72, 169-180.

Beck-Friis, B., Smars, S., Jönsson, H., \& Kirchmann, H. (2001). Gaseous emissions of carbon dioxide, ammonia and nitrous oxide from organic household waste in a compost reactor under different temperature regimes. Journal of agricultural engineering research, 78, 423-430. 
Bending, G. D., Turner, M. K., \& Burns, I. G. (1998). Fate of nitrogen from crop residues as affected by biochemical quality and the microbial biomass. Soil Biology and Biochemistry, 30, 2055-2065.

Berendse, F., Berg, B., \& Bosatta, E. (1987). The effect of lignin and nitrogen on the decomposition of litter in nutrient-poor ecosystems: a theoretical approach. Candian Journal of Botany, 65, 1116-1120.

Bhardwaj, K. K. R. (1995). Recycling of crop residues oilcakes and other plant products in agriculture. In H. L. S. Tandon (Ed.), Recycling of crop, animal, human and industrial wastes in agriculture. (pp. 9-30). New Delhi: Fertilizer Development and Consultation Organization.

Bidegain, R. A., Kaemmerer, M., Guiresse, M., Hafidi, M., Rey, F., Morard, P., \& Revel, J. C. (2000). Effects of humic substances from composted or chemically decomposed poplar sawdust on mineral nutrition of ryegrass. The Journal of Agricultural Science, $134,259-267$.

Bishop, P. L., \& Godfrey, C. (1983). Nitrogen transformations during sludge composting. Biocycle, 24, 34-39.

Blair, G. J., Lefroy, R. D. B., \& Lisle, L. (1995). Soil carbon fractions based on their degree of oxidation, and the development of a carbon management index for agricultural systems. Australian Journal of Agricultural Research, 46, 1459-1466.

Blanchart, E., Albrecht, A., Alegre, J., Duboisset, A., Gilot, C., Pashanasi, B., Lavelle, P., \& Brussaard, L. (1999). Effects of earthworms on soil structure and physical properties. Earthworm management in tropical agroecosystems. CAB International, Wallingford, UK. p, 149-172.

Brewer, L. J., \& Sullivan, D. M. (2003). Maturity and stability evaluation of composted yard trimmings. Compost Science and Utilization, 11, 96-112. 
Brown, G. G., Barois, I., \& Lavelle, P. (2000). Regulation of soil organic matter dynamics and microbial activityin the drilosphere and the role of interactionswith other edaphic functional domains. European Journal of Soil Biology, 36, 177-198.

Buckerfield, J. C., Flavel, T. C., Lee, K. E., \& Webster, K. A. (1999). Vermicompost in solid and liquid forms as a plant-growth promoter. Pedobiologia, 43, 753-759.

Butt, K. R. (1993). Utilization of solid paper-mill sludge and spent brewery yeast as feed for soil dwelling earthworms. Bioresource Technology, 44, 105-107.

Canti, M. G., \& Piearce, T. G. (2004). Morphology and dynamics of calcium carbonate granules produced by different earthworm species. Pedobiologia, 47, 5, 511-521.

Carter, M. R., Gregorich, E. G., Angers, D. A., Beare, M. H., Sparling, G. P., Wardle, D. A., \& Voroney, R. P. (1999). Interpretation of microbial biomass measurements for soil quality assessment in humid temperate regions. Canadian Journal of Soil Science, 79, 507-520.

Chan, P. L. S., \& Griffiths, D. A. (1988). The vermicomposting of pre-treated pig manure. Biological Wastes, 24, 57-69.

Chaoui, H. I., Zibilske, L. M., \& Ohno, T. (2003). Effects of earthworm casts and compost on soil microbial activity and plant nutrient availability. Soil Biology and Biochemistry, 35, 295-302.

Charley, J. L., \& West, N. E. (1975). Plant-induced soil chemical patterns in some shrubdominated semi-desert ecosystems of Utah. Journal of Ecology, 63, 945-963.

Cooperband, L. R., Power, J. F., Dick, W. A., Kashmanian, R. M., Sims, J. T., Wright, R. J., Dawson, M. D., \& Bezdicek, D. (2000). Sustainable use of by-products in land management. Land application of agricultural, industrial, and municipal by-products, 215-235. 
Cooperband, L. R., Stone, A. G., Fryda, M. R., \& Ravet, J. L. (2003). Relating compost measures of stability and maturity to plant growth. Compost Science \& Utilization, 11, 113-124.

Cox, D. A. (1993). Reducing nitrogen leaching-losses from containerized plants: The effectiveness of controlled-release fertilizers. Journal of Plant Nutrition, 16, 533-545.

Cronje', A. L., Turners, C., Williams, A. G., Barker, A. J., \& Guy, S. (2004). The respiration rate of composting pig manure. Compost Science \& Utilization, 12, 119-129.

de Bertoldi, M., Vallini, G., Pera, A., \& Zucconi, F. (1985). Technological aspects of composting including modelling and microbiology. In J. K. R. Gasser (Ed.), Composting of Agricultural and Other Wastes London and New York. : Elsevier Applied Science.

De Brito, A., Gagne, S., \& Antoun, H. (1995). Effect of compost on rhizosphere microflora of the tomato and on the incidence of plant growth-promoting rhizobacteria. Applied and Environmental Microbiology, 61, 194-199.

Diaz, L. F., \& Savage, G. M. (2007). Factors that affect the process. In L. F. Diaz, M. De Bertoldi \& W. Bidlingmaier (Eds.), Compost science and technology (pp. 49-64). Concord, USA: Elsevier Science.

Dick, W. A., \& Gregorich, E. G. (2004). Developing and maintaining soil organic matter levels. In P. Schjønning, S. Elmholt \& B. T. Christensen (Eds.), Managing Soil Quality Challenges in Modern Agriculture (pp. 103-120). Wallingford, UK: CAB International.

Diop, A. M. (1999). Sustainable agriculture: New paradigms and old practices? Increased production with management of organic inputs in Senegal. Environment, Development and Sustainability, 1, 285-296.

Dominguez, J., \& Edwards, C. A. (1997). Effects of stocking rate and moisture content on the growth and maturation of Eisenia andrei (Oligochaeta) in pig manure. Soil Biology and Biochemistry, 29, 743-746. 
Doran, J. W., \& Parkin, T. B. (1994). Defining and assessing soil quality. In J. W. Doran, D. C. Coleman, D. F. Bezdicek \& B. A. Stewart (Eds.), Defining Soil Quality for a Sustainable Environment (pp. 3-21). Madison, Wisconsin: SSSA Special Publication No 35. Soil Science Society of America.

Doube, B. M., \& Brown, G. G. (1998). Life in a complex community: functional interactions between earthworms, organic matter, microorganisms, and plants. St. Lucie Press, Boca Raton, FL: CRC Press.

Doube, B. M., Williams, P. M. L., \& Willmott, P. J. (1997). The influence of two species of earthworm (Aporrectodea trapezoides and Aporrectoedea rosea) on the growth of wheat, barley and faba beans in three soil types in the greenhouse. Soil Biology and Biochemistry, 29, 503-509.

Douglas, C. L., \& Rickman, R. W. (1992). Estimating crop residue decomposition for air temperature, initial nitrogen content, and residue placement. Soil Science Society of America journal (USA).

Edwards, C. A. (1998). The use of earthworms in the breakdown and management of organic wastes. In C. A. Edwards (Ed.), Earthworm Ecology (pp. 327-354). Boca Raton: Lewis.

Edwards, C. A. (2004). The use of earthworms in processing organic wastes into plant growth media and animal feed protein. Edwards, CA (ed), 327.

Edwards, C. A., \& Bohlen, P. J. (1996). Biology and Ecology of Earthworms. London: Chapman \& Hall.

Edwards, C. A., \& Burrows, I. (1988). The potential of earthworm composts as plant growth media. In C. A. Edwards \& E. Neuhauser (Eds.), Earthworms in Waste and Environmental Management (pp. 21-32). The Hague, The Netherlands: SPB Academic Press. 
Edwards, C. A., Burrows, I., Fletcher, K. E., \& Jones, B. A. (1985). The use of earthworms for composting farm wastes. In J. K. R. Gasser (Ed.), Composting agricultural and other wastes. (pp. 229-242). UK.

Elvira, C., Goicoechea, M., Sampedro, L., Mato, S., \& Nogales, R. (1996). Bioconversion of solid paper-pulp mill sludge by earthworms. Bioresource Technology, 57, 173-177.

Elvira, C., Sampedro, L., Benitez, E., \& Nogales, R. (1998). Vermicomposting of sludges from paper mill and dairy industries with Eisenia andrei: a pilot-scale study. Bioresource Technology, 63, 205-211.

Eriksen, G. N., Coale, F. J., \& Bollero, G. A. (1999). Soil nitrogen dynamics and maize production in municipal solid waste amended soil. Agronomy Journal, 91, 1009-1016.

Finstein, M. S., Miller, F. C., Strom, P. F., MacGregor, S. T., \& Psarianos, K. M. (1983). Composting ecosystem management for waste treatment. Nature Biotechnology, 1, 347353.

Finstein, M. S., Strom, P. F., Hogan, J. A., \& Cowan, R. M. (1999). Composting on Mars or the Moon: I. Comparative evaluation of process design alternatives. Life support \& biosphere science: international journal of earth space, 6, 169-169.

Fox, R. H., Myers, R. J. K., \& Vallis, I. (1990). The nitrogen mineralization rate of legume residues in soil as influenced by their polyphenol, lignin, and nitrogen contents. Plant and Soil, 129, 251-259.

Fracchia, L., Dohrmann, A. B., Martinotti, M. G., \& Tebbe, C. C. (2006). Bacterial diversity in a finished compost and vermicompost: differences revealed by cultivationindependent analyses of PCR-amplified 16S rRNA genes. Applied Microbiology and Biotechnology, 71, 942-952. 
Fragstein, P., \& Schmidt, H. (1999). External N sources in an organic stockless crop rotation-useful or useless additives? Paper presented at the Proceedings from an International Workshop. Designing and Testing of Crop Rotations for Organic Farming.

Gabrielle, B., Da-Silveira, J., Houot, S., \& Francou, C. (2004). Simulating urban waste compost effects on carbon and nitrogen dynamics using a biochemical index. J. Environ. Qual, 33, 2333-2342.

Gallardo-Lara, F., \& Nogales, R. (1987). Effect of the application of town refuse compost on the soil-plant system: A review. Biological Wastes, 19, 35-62.

Gallardo, A., \& Merino, J. (1993). Leaf decomposition in two Mediterranean ecosystems of southwest Spain: influence of substrate quality. Ecology, 74, 152-161.

Garcia-Gomez, A., Bernal, M., \& Roig, A. (2002). Growth of ornamental plants in two composts prepared from agroindustrial wastes. Bioresource Technology, 83, 81-87.

Garcia, C., Ceccanti, B., Masciandaro, G., \& Hernandez, T. (1995). Phosphatase and $\beta$ glucosidase activities in humic substances from animal wastes. Bioresource Technology, $53,79-87$.

Giller, K. E., \& Cadisch, G. (1997). Driven by nature: a sense of arrival or departure?

Giusquiani, P. L., Gigliotti, G., \& Businelli, D. (1995). Urban waste compost: effects on physical, chemical, and biochemical soil properties. Journal of Environmental Quality, 24.

Glanz, J. (1995). Saving our soil: solutions for sustaining earth's vital resource. Boulder, CO, USA: Johnson Books.

Godden, B., Ball, A. S., Helvenstein, P., McCarthy, A. J., \& Penninckx, M. J. (1992). TOWARDS ELUCIDATION OF THE LIGNIN DEGRADATION PATHWAY IN ACTINOMYCETES. Journal of General Microbiology, 138, 2441-2448. 
Goering, H. K., \& Van Soest, P. J. (1970). Forage fiber analyses: Apparatus, reagents, procedures, and some applications.

Golueke, C. G. (1973). Composting. A Study of the Process and its Principles. Emmaus, Pennsylvania, USA: Rodale Press Inc.

Golueke, C. G., Lafrenz, D., Chaser, B., \& Diaz, L. F. (1980). Composting combined refuse and sewage sludge. Compost Sci./Land Utiliz, 21, $42-48$.

Govers, G., Poesen, J., Goossens, D., Schjnning, P., Elmholt, S., \& Christensen, B. T. (2004). Soil Erosion-Processes, Damages and Countermeasures. In P. Schjønning, S. Elmholt \& B. T. Christensen (Eds.), Managing soil quality: challenges in modern agriculture (pp. 199-217). Wallingford, UK CAB International.

Grapeelli, A., Galli, E., \& Tomati, U. (1987). Earthworm casting effect on Agaricus bisporus fructification. Agrochimica, 31, 457-462.

Gregorich, E. G., Carter, M. R., Angers, D. A., Monreal, C. M., \& Ellert, B. H. (1994). Towards a minimum data set to assess soil organic matter quality in agricultural soils. Canadian Journal of Soil Science, 74, 367-385.

Hashemimajd, K., Kalbasi, M., Golchin, A., \& Shariatmadari, H. (2004). Comparison of vermicompost and composts as potting media for growth of tomatoes. Journal of Plant Nutrition, 27, 1107-1123.

Haynes, R., \& Swift, R. (2006). Stability of soil aggregates in relation to organic constituents and soil water content. Journal of Soil Science, 41, 73-83.

Haynes, R. J. (1986). The decomposition process: mineralization, immobilization, humus formation, and degradation. Mineral nitrogen in the plant-soil system., 52-126.

Hernando, S., Lobo, M., \& Polo, A. (1989). Effect of the application of a municipal refuse compost on the physical and chemical properties of a soil. Science of the Total Environment, 81, 589-596. 
Hoitink, H. A. J., \& Boehm, M. J. (1999). Biocontrol within the context of soil microbial communities: a substrate-dependent phenomenon. Annual Review of Phytopathology, 37, 427-446.

Hudson, B. D. (1994). Soil organic matter and available water capacity. Journal of Soil and Water Conservation, 49, 189-189.

Imbeah, M. (1998). Composting piggery waste: a review. Bioresource Technology, 63, 197-203.

Janzen, H. H., \& Kucey, R. M. N. (1988). C, N, and S mineralization of crop residues as influenced by crop species and nutrient regime. Plant and Soil, 106, 35-41.

Jastrow, J. D., \& Miller, R. M. (1991). Methods for assessing the effects of biota on soil structure. Agriculture, Ecosystems \& Environment, 34, 279-303.

Jenkinson, D. S., Hart, P. B. S., Rayner, J. H., \& Parry, L. C. (1987). Modelling the turnover of organic matter in long-term experiments at Rothamsted.

Jones, C. G., Lawton, J. H., \& Shachak, M. (1994). Organisms as ecosystem engineers. Oikos, 69, 373-386.

Jouquet, E., Bloquel, E., Doan, T. T., Ricoy, M., Orange, D., Rumpel, C., \& Due, T. (2011). Do Compost and Vermicompost Improve Macronutrient Retention and Plant Growth in Degraded Tropical Soils? Compost Science \& Utilization, 19, 15-24.

Kale, R. D., Mallesh, B., Kubra, B., \& Bagyaraj, D. (1992). Influence of vermicompost application on the available macronutrients and selected microbial populations in a paddy field. Soil Biology and Biochemistry, 24, 1317-1320.

Kapoor, K. K., \& Bansal, S. (2000). Vermicomposting of crop residues and cattle dung with Eisenia foedita. Bioresource Technology, 73 95-98.

Karlen, D. L., Andrews, S. S., Wienhold, B. J., Schjnning, P., Elmholt, S., \& Christensen, B. T. (2004). Soil quality, fertility and health-historical context, status and perspectives. 
In P. Schjønning, S. Elmholt \& B. T. Christensen (Eds.), Managing soil quality: challenges in modern agriculture (pp. 17-33). Wallingford, UK CAB International.

Karlen, D. L., Mausbach, M. J., Doran, J. W., Cline, R. G., Harris, R. F., \& Schuman, G. E. (1997). Soil quality: a concept, definition, and framework for evaluation.

Krishnamoorthy, R. V., \& Vajranabhaiah, S. N. (1986). Biological activity of earthworm casts: An assessment of plant growth promotor levels in the casts. Proceedings: Animal Sciences, 95, 341-351.

Kumar, K., \& Goh, K. M. (1999). Crop residues and management practices: effects on soil quality, soil nitrogen dynamics, crop yield, and nitrogen recovery. Advances in Agronomy, 68, 197-319.

Lal, R. (2000). Soil management in the developing countries. Soil Science, 165, 57-57.

Lal, R. (2001). Soil Carbon Sequestration and the Greenhouse Effect; SSSA Spec. Publ. No. 57 Madison, WI: Soil Science Society of America.

Laos, F., Satti, P., Walter, I., Mazzarino, M. J., \& Moyano, S. (2000). Nutrient availability of composted and noncomposted residues in a Patagonian Xeric Mollisol. Biology and Fertility of Soils, 31, 462-469.

Larson, W. E., \& Pierce, F. J. (1994). The dynamics of soil quality as a measure of sustainable management. In J. W. Doran, C. Coleman, D. F. Bezdicek \& B. A. Stewart (Eds.), Defining soil quality for a sustainable environment. SSSA Spec. Publ. 35 (pp. $37-$ 51). Madison, WI: SSSA and ASA.

Lattaud, C., Zhang, B. G., Locati, S., Rouland, C., \& Lavelle, P. (1997). Activities of the digestive enzymes in the gut and in tissue culture of a tropical geophagous earthworm, Polypheretima elongata (Megascolecidae). Soil Biology and Biochemistry, 29, 335-339. 
Lavelle, P., Bignell, D., Lepage, M., Wolters, W., Roger, P., Ineson, P., Heal, O. W., \& Dhillion, S. (1997). Soil function in a changing world: the role of invertebrate ecosystem engineers. European Journal of Soil Biology, 33, 159-193.

Lazcano, C., Arnold, J., Tato, A., Zaller, J., \& Domínguez, J. (2009). Compost and vermicompost as nursery pot components: effects on tomato plant growth and morphology. Spanish journal of agricultural research, 944-951.

Lazcano, C., Gómez-Brandón, M., \& Domínguez, J. (2008). Comparison of the effectiveness of composting and vermicomposting for the biological stabilization of cattle manure. Chemosphere, 72, 1013-1019.

Lee, K. E. (1985). Earthworms: Their Ecology and Relationships with Soils and Land Use. Sydney, Australia: Academic Press.

Liu, X., Han, X., Song, C., Herbert, S. J., \& Xing, B. (2003). Soil organic carbon dynamics in black soils of China under different agricultural management systems. Communications in Soil Science and Plant Analysis, 34, 973-984.

Loehr, R. C., Neuhauser, E. F., \& Malecki, M. R. (1985). Factors affecting the vermistabilization process: Temperature, moisture content and polyculture. Water Research, 19, 1311-1317.

MacGregor, S. T., Miller, F. C., Psarianos, K. M., \& Finstein, M. S. (1981). Composting process control based on interaction between microbial heat output and temperature. Applied and Environmental Microbiology, 41, 1321-1321.

Madejón, E., Burgos, P., Murillo, J. M., \& Cabrera, F. (2001). Phytotoxicity of organic amendments on activities of select soil enzymes. Communications in Soil Science and Plant Analysis, 32, 2227-2239.

Mahieu, N., Powlson, D. S., \& Randall, E. W. (1999). Statistical analysis of published carbon-13 CPMAS NMR spectra of soil organic matter. Soil Science Society of America Journal, 63, 307-319. 
Mamo, M., Rosen, C. J., Halbach, T. R., \& Moncrief, J. F. (1998). Corn yield and nitrogen uptake in sandy soils amended with municipal solid waste compost. Journal of production agriculture, 11, 469-475.

Marinissen, J. C. Y., \& Dexter, A. R. (1990). Mechanisms of stabilization of earthworm casts and artificial casts. Biology and Fertility of Soils, 9, 163-167.

Martin, A., \& Marinissen, J. C. Y. (1993). Biological and physico-chemical processes in excrements of soil animals. Geoderma, 56, 331-347.

Mays, D. A., Duggan, G. L., \& others. (1973). Municipal Compost: Effects on Crop Yields and Soil Properties1. Journal of Environmental Quality, 2, 89-89.

Mba, C. C. (1996). Treated-cassava peel vermicomposts enhanced earthworm activities and cowpea growth in field plots. Resources, conservation and recycling, 17, 219-226.

McLaughlin, N. B., Gregorich, E. G., Dwyer, L. M., \& Ma, B. L. (2002). Effect of organic and inorganic soil nitrogen amendments on mouldboard plow draft. Soil and Tillage Research, 64, 211-219.

Melillo, J. M., Aber, J. D., \& Muratore, J. F. (1982). Nitrogen and lignin control of hardwood leaf litter decomposition dynamics. Ecology, 63, 621-626.

Miller, F. C. (1989). Matric water potential as an ecological determinant in compost, a substrate dense system. Microbial Ecology, 18, 59-71.

Mishra, M. M., Kukreja, K., Kapoor, K. K., \& Bangar, K. C. (1989). Organic recycling for plant nutrients. In L. L. Somani \& C. S. Bhandari (Eds.), Soil Microorganisms and Crop Growth (pp. 195-232). Divyajyoti Parkashan: Jodhpur.

Mitchell, A. (1997). Production of Eisenia fetida and vermicompost from feed-lot cattle manure. Soil Biology and Biochemistry, 29, 763-766. 
Morris, D. R., Gilbert, R. A., Reicosky, D. C., \& Gesch, R. W. (2004). Oxidation potentials of soil organic matter in Histosols under different tillage methods. Soil Science Society of America Journal, 68, 817-826.

Mosier, A., \& Kroeze, C. (1998). A new approach to estimate emissions of nitrous oxide from agriculture and its implications for the global $\mathrm{N} 2 \mathrm{O}$ budget. Global Change Newsletter, 34, 8-13.

Nakamura, Y. (1996). Interactions between earthworms and microorganisms in biological control of plant root pathogens. Farming Japan, 30, 37-43.

Nakasaki, K., Yaguchi, H., Sasaki, Y., \& Kubota, H. (1993). Effects of pH control on composting of garbage. Waste Management and Research, 11, 117-125.

Ndegwa, P. M., \& Thompson, S. A. (2001). Integrating composting and vermicomposting in the treatment and bioconversion of biosolids. Bioresource Technology, 76, 107-112.

Newbould, P. (1989). Nitrogen factor in organic matter cycling and utilisation in arid soils. Arid Land Research and Management, 3, 295-313.

Northup, R. R., Yu, Z., Dahlgren, R. A., \& Vogt, K. A. (1995). Polyphenol control of nitrogen release from pine litter. Nature, 377, 227-229.

Nziguheba, G. (2007). Overcoming phosphorus deficiency in soils of Eastern Africa: recent advances and challenges. Advances in Integrated Soil Fertility Management in sub-Saharan Africa: Challenges and Opportunities, 149-160.

Ogunwande, G. A., \& Osunade, J. A. (2011). Passive aeration composting of chicken litter Effects of aeration pipe orientation and perforation size on losses of compost elements. Journal of Environmental Management, 92, 85-91. 
Orozco, F. H., Cegarra, J., Trujillo, L. M., \& Roig, A. (1996). Vermicomposting of coffee pulp using the earthworm Eisenia fetida: effects on $\mathrm{C}$ and $\mathrm{N}$ contents and the availability of nutrients. Biology and Fertility of Soils, 22, 162-166.

Ouedraogo, E., Mando, A., \& Brussaard, L. (2006). Soil macrofauna affect crop nitrogen andáwater use efficiencies in a semi-arid West Africa. European Journal of Soil Biology, $42,275-277$.

Palm, C. A., \& Sanchez, P. A. (1991). Nitrogen release from the leaves of some tropical legumes as affected by their lignin and polyphenolic contents. Soil Biology and Biochemistry, 23, 83-88.

Parkinson, R. J., Fuller, M. P., \& Groenhof, A. C. (1999). An evaluation of greenwaste compost for the production of forage maize (Zea mays L.). Compost Science and Utilization, 7, 72-80.

Paul, E. A., \& Clark, F. E. (1989). Soil microbiology and biochemistry. Academic Press. San Diego, USA.

Pretty, J. N. (1995). Regenerating agriculture: Policies and practice for sustainability and self-reliance. Washington: Joseph Henry Press.

Reeves, D. W. (1997). The role of soil organic matter in maintaining soil quality in continuous cropping systems. Soil and Tillage Research, 43, 131-167.

Reinecke, A. J., Viljoen, S. A., \& Saayman, R. J. (1992). The suitability of Eudrilus eugeniae, Perionyx excavatus and Eisenia fetida (Oligochaeta) for vermicomposting in southern Africa in terms of their temperature requirements. Soil Biology and Biochemistry, 24, 1295-1307.

Richard, T. L., Hamelers, H. V. M., Veeken, A., \& Silva, T. (2002). Moisture relationships in composting processes. Compost Science and Utilization, 10, 286-302. 
Richard, T. L., Veeken, A. H. M., de Wilde, V., \& Hamelers, H. V. M. (2004). Air-Filled Porosity and Permeability Relationships during Solid-State Fermentation. Biotechnology progress, 20, 1372-1381.

Rodrigues, M. S., Lopez-Real, J. M., \& Lee, H. C. (1996). Use of composted societal organic wastes for sustainable crop production. In M. De Bertoldi, P. Sequi, B. Lemmes \& T. Papi (Eds.), The Science of Composting (pp. 447-456). London: Blackie Academic \& Professional.

Schlecht, E., Buerkert, A., Tielkes, E., \& Bationo, A. (2006). A critical analysis of challenges and opportunities for soil fertility restoration in Sudano-Sahelian West Africa. Nutrient Cycling in Agroecosystems, 76, 109-136.

Shen, H., Cao, Z. H., \& Hu, Z. Y. (1999). Characteristics and ecological effects of the active organic carbon in soil. Chinese Journal of Ecology, 18, 32-38.

Shi-Wei, Z., \& Fu-Zhen, H. (1991). The nitrogen uptake efficiency from 15N labeled chemical fertilizer in the presence of earthworm manure (cast). Advances in Management and Conservation of Soil Fauna. Oxford and IBH publishing Co., New Delhi, Bombay, $539-542$.

Six, J., Elliott, E. T., \& Paustian, K. (2000). Soil macroaggregate turnover and microaggregate formation: a mechanism for $\mathrm{C}$ sequestration under no-tillage agriculture. Soil Biology and Biochemistry, 32, 2099-2103.

Smith, O. H., Petersen, G. W., \& Needelman, B. A. (2000). Environmental indicators of agroecosystems. Advances in Agronomy, 69, 75-97.

Stockdale, E. A., \& Rees, R. M. (1995). Release of nitrogen from plant and animal residues and consequent plant uptake efficiency. [Proceedings Paper]. Biological Agriculture \& Horticulture, 11, 229-245.

Stout, J. D., Goh, K. M., \& Rafter, T. A. (1981). Chemistry and turnover of naturally occurring resistant organic compounds in soil. Soil biochemistry, 5, 1-73. 
Sundberg, C., Smlaars, S., \& Jlönsson, H. (2004). Low pH as an inhibiting factor in the transition from mesophilic to thermophilic phase in composting. Bioresource Technology, 95, 145-150.

Suthar, S. (2009). Impact of vermicompost and composted farmyard manure on growth and yield of garlic (Allium stivum L.) field crop. International Journal of plant production, 3, 27-38.

Szczech, M., Rondomanski, W., Brzeski, M. W., Smolinska, U., \& Kotowski, J. F. (1993). Suppressive effect of a commercial earthworm compost on some root infecting pathogens of cabbage and tomato. Biological Agriculture and Horticulture (United Kingdom).

Thankamani, C. K., Sivaraman, K., \& Kandiannan, K. (1996). Response of clove (Syzygium aromaticum (L.) Merr. \& Perry) seedlings and black pepper (Piper nigrum L.) cuttings to propagating media under nursery conditions.

Thomsen, I. K. (2001). Recovery of nitrogen from composted and anaerobically stored manure labelled with 15N. European journal of agronomy, 15, 31-41.

Tian, G., Brussaard, L., \& Kang, B. T. (1995). Breakdown of plant residues with contrasting chemical compositions under humid tropical conditions: effects of earthworms and millipedes. Soil Biology and Biochemistry, 27, 277-280.

Tognetti, C., Laos, F., Mazzrino, M. J., \& Hernandez, M. T. (2005). Composting vs. vermicomposting: a comparison of end product quality. Compost Science \& Utilization, $13,6-13$.

Tomati, U., Grappelli, A., \& Galli, E. (1988). The hormone-like effect of earthworm casts on plant growth. Biology and Fertility of Soils, 5, 288-294.

Tripathi, G., \& Bhardwaj, P. (2004). Decomposition of kitchen waste amended with cow manure using an epigeic species (Eisenia fetida) and an anecic species (Lampito mauritii). Bioresource Technology, 92, 215-218. 
Tuitert, G., Szczech, M., \& Bollen, G. J. (1998). Suppression of Rhizoctonia solani in potting mixtures amended with compost made from organic household waste. Phytopathology, 88, 764-773.

Tuomela, M., Vikman, M., Hatakka, A., \& Itavaara, M. (2000). Biodegradation of lignin in a compost environment: a review. Bioresource Technology, 72, 169-183.

Valus, I., \& Jones, R. J. (1973). Net mineralization of nitrogen in leaves and leaf litter of Desmodium intortum and Phaseolus atropurpureus mixed with soil. Soil Biology and Biochemistry, 5, 391-398.

Van Bruggen, A. H. C., \& Semenov, A. M. (2000). In search of biological indicators for soil health and disease suppression. Applied Soil Ecology, 15, 13-24.

Vigil, M. F., \& Kissel, D. E. (1991). Equations for estimating the amount of nitrogen mineralized from crop residues. Soil Science Society of America journal (USA).

Vinceslas-Akpa, M., \& Loquet, M. (1997). Organic matter translocations in lignocellulosic waste products composted or vermicomposted (Eisenia fetida andrei): Chemical analysis and 13C CPMAS NMR spectroscopy. Soil Biology and Biochemistry, $29,751-758$.

Vivas, A., Moreno, B., Garcia-Rodriguez, S., \& Benítez, E. (2009). Assessing the impact of composting and vermicomposting on bacterial community size and structure, and microbial functional diversity of an olive-mill waste. Bioresource Technology, 100, 1319-1326.

Volterrani, M., Pardini, G., Gaetani, M., Grossi, N., \& Miele, S. (1996). Effects of application of municipal solid waste compost on horticultural species yield.

West, N. E., \& Skujinš, J. (1978). Nitrogen in desert ecosystems. Stroudsburg, Pennsylvania.: Dowden, Hutchinson and Ross Inc. 
Wilson, D. P., \& Carlile, W. R. (1988). Plant growth in potting media containing wormworked duck waste. Acta Horticulturae, 238, 205-220.

Wu, L., Ma, L. Q., Martinez, G. A., \& others. (2000). Comparison of methods for evaluating stability and maturity of biosolids compost. Journal of Environmental Quality, 29, 424-429.

Xiao, Y., Zeng, G. M., Yang, Z. H., Ma, Y. H., Huang, C., Xu, Z. Y., Huang, J., \& Fan, C. Z. (2011). Changes in the actinomycetal communities during continuous thermophilic composting as revealed by denaturing gradient gel electrophoresis and quantitative PCR. Bioresource Technology, 102, 1383-1388. 


\section{Changes of the chemical composition of the cotton residue during decomposition}

\subsection{Introduction}

Chemical composition of the organic materials is the most essential criterion in its recycling, marketing and utilization in agriculture (Lasaridi et al., 2006). The tremendous amount of organic matter and mineral components that are contained in biowastes (municipal solid waste, sewage sludge, manures, etc.) allows its application for crop production and soil reclamation, after a proper stabilization process (Veeken et al., 2000). Nevertheless, the organic amendments prepared from different organic wastes (raw materials), using different methods (composting or vermicomposting) and time of processing, produce a final product which differs in its quality (Gaur \& Singh, 1995; Ranalli et al., 2001).

One of the important factors affecting the successful application of compost and/or vermicompost for agricultural practices is its degree of maturity and stability. If an unstable or immature decomposed material is applied, it can induce anaerobic conditions as the microorganisms utilize the $\mathrm{O}_{2}$ to decompose the substrate (Mathur et al., 1993). Another problem associated with the fore mentioned application is the phytotoxicity due the presence of low molecular weight acids, phytotoxins and other organic compounds at phytotoxic levels (Senesi, 1989; L Wu et al., 2000).

Compost and / or vermicompost maturity and stability are commonly used to define the degree of decomposition of the organic matter. Substrate's stability refers to the level of activity of the microbial biomass, while maturity refers to degree of the decomposition of the phytotoxic organic constituents (Conti et al., 1997; Iannotti et al., 1994; Wu et al., 2000).

During the evaluation of the quality of the substrates, all parameters referring to the overall quality would have to be considered, these are physical, chemical and biological characteristics. As the organic source becomes more diverse (different substrates or their mixtures), this problem becoming more acute, and the possibility of defining general guidelines for production and safe usage is becoming more complex to establish (Goyal et al., 2005; Wang et al., 2004; Zmora-Nahum et al., 2005). 
Numbers of criteria and parameters have been proposed for testing stability and/ or maturity of the organic materials during the decomposition process and in the final product (Mathur et al., 1993; Namkoong et al., 1999; Wu et al., 2000).

Indexes and parameters are generally divided into sensor, physical, chemical and biochemical. Physical parameters include bulk density and purity and sensor tests which include colour and odour. These tests give general idea of the decomposition stage reached, but offer little information as regards the degree of maturation. For this, chemical methods are widely used in favor the physical ones, including C:N ratio of the solid and in water extract of the finished product, inorganic nitrogen, $\mathrm{pH}$, electrical conductivity, as well as cation exchange capacity (CEC) (Bernal et al., 1998a; Chefetz et al., 1998; Zmora-Nahum et al., 2005). Oxygen uptake rate, $\mathrm{CO}_{2}$ evolution and heat release were also used as measures of the level of the microbial biomass and activity that refers in turn to the substrate stability (Conti et al., 1997; Iannotti et al., 1994).

Germination index, which is a measure of phytotoxicity, is calculated from germinated seeds and measured radicle growth of seeds grown on filter paper moistened with extracts of compost or vermicompost is commonly used as an indirect assessment of the maturity of compost and vermicompost (Cunha Queda et al., 2002).

Different standard ranges and critical levels have been proposed for maturity and stability. Indexes used for comparing compost and vermicompost in large bodies of literature seems to be the same irrespective of the organic materials used, this is mainly because indexes were generated from the finished products. At curing and maturity of the composting, the high temperature generated by the microorganisms during the thermophilic stage tends to decline with time to the ambient, and hence, mesophilic organisms recolonize the mass. Vermicomposting is well known as a mesophilic process during which, the process must be maintained at temperature below $35^{\circ} \mathrm{C}$ because exposure of worms to temperature above this will kill them (Ndegwa \& Thompson, 2001).

As a criteria for substrate maturity and stability, a germination index of $>50 \%$ of cress seed (Lepidium sativum L) (Zucconi et al., 1981); $\mathrm{NH}_{4}^{+} / \mathrm{NO}_{3}^{-}$ratio of $<0.16$ and $\mathrm{NH}_{4}-\mathrm{N}$ 
of $<0.04 \%$ (fresh weight basis), are used as indicator for maturity (Bernal et al., 1998b; Pare' et al., 1998).

Equally important is the assessment of the stability of the decomposed material using

$\mathrm{CO}_{2}$ evolution. It is suggested that evolution of $\mathrm{CO}_{2}$ of $<1 \mathrm{mg} \mathrm{CO}_{2}-\mathrm{Cg}[\mathrm{dw}]^{-1} \mathrm{~d}^{-1}$ indicates stability (Thompson et al., 2003; Wang et al., 2004). Here, most of available substrate has been mineralized and microbial activities are low such that when the material is incorporated into the soil, it does not create a surge in microbial activities resulting in excess demand for nitrogen.

Other parameters like total organic carbon content, total nitrogen content, phosphorus and potassium content, heavy metals, salinity, water holding capacity, bulk density, and reduction in pathogens and weed seeds, and presence of indicator organisms, have also been used to determine the state of maturity and/or stability (Cunha Queda et al., 2002; Huang et al., 2001; Lasaridi et al., 2006). However, it is difficult to apply these parameters across a wide range of compost or vermicompost prepared from organic materials (Benito et al., 2003; Roletto et al., 1985; Saviozzi et al., 1988), additionally, no single method can universally be applied to all composts and vermicomposts due to the wide range of feedstocks used and different decomposition processes applied (He et al., 1995; Itavaara et al., 2002; Wang et al., 2004). Although composting and vermicomposting of different crop residues have been vigorously examined in organic wastes management research over the past decades, no work has been carried out especially in Sudan to the decomposition of the cotton residues and to look for simple and practical maturity and stability indexes.

\section{2. $\underline{\text { Aims }}$}

There is little or no information available on the effectiveness of composting and vermicomposting on the biological stabilization of cotton residues. Therefore, the specific objectives of this part were to (1) monitor chemical changes during composting and vermicomposting of cotton residues, (2) to elaborate and correlate the results of the chemical changes with the data of the bioassays performed on plants, and (3) to determine quality parameters that best describe finished composts and vermicomposts. 


\subsection{Materials and methods}

\subsubsection{Methods}

\subsubsection{Characterization of feedstock and composting}

Cotton residues used in this study were collected from farms located in the El Gazira irrigated farming systems (El Gazira State, Sudan, $33^{\circ} 30^{\prime} \mathrm{E} 14^{\circ} 24^{\prime} \mathrm{N}$ and at altitude of $390 \mathrm{~m}$ asl. The site soil was classified as Fine Montmorillonitic, Isohyperthermic, Enticchromustert (Soil Survey Staff, 1996); from where samples were collected from the top $30 \mathrm{~cm}$. The farm yard manure (FYM) was obtained from the Institute of Animal Husbandry, University of Göttingen, Germany. The chemical characteristics of the raw materials are depicted in Table 4.1.

\subsubsection{Experimental setup}

Cotton residues were chopped to approximately less than $5 \mathrm{~cm}$ length, and soil was ground to pass $2 \mathrm{~mm}$ sieve. Composting and vermicomposting were carried out under aerobic conditions; during which the mixtures were subjected to interval turning every two weeks. Heaps were constructed in layers of cotton residues interspersed with FYM and soil in a ratio of 5:1:1 for composting and a ratio of 5:1 of cotton residues and soil for the vermicomposting. The moisture content of the mixture was maintained at $60-65 \%$ of water holding capacity (WHC) of compost and $70-75 \%$ of vermicompost throughout the experiment period (20 weeks) by adding water when necessary. The composting materials were assigned in a silo with openings at the cover and bottom for vermicomposting and plastic barrel with openings at the cover for composting with no replications. Earthworms (Lumbricus terrestris) were brought from the company of Martin Langhoff (SUPERWURM e.K.) and were introduced into the silo. At each sampling, earthworms were hand sorted and returned to the silo. 
Table 4.1: Raw material of the study

\begin{tabular}{lccccc}
\hline Material (dry) & $\mathrm{pH}_{\mathrm{H} 2 \mathrm{O}}$ & $\begin{array}{c}\text { Total C } \\
(\%)\end{array}$ & $\begin{array}{c}\text { Total N } \\
(\%)\end{array}$ & $\mathrm{C}: \mathrm{N}$ & $\mathrm{P}(\mathrm{mg} / \mathrm{kg})$ \\
\hline Soil & 8.1 & 0.68 & 0.03 & 22.7 & 25.1 \\
Farm yard manure & 6.7 & 26.3 & 1.1 & 23.9 & 186.6 \\
Cotton residues & 5.4 & 45.2 & 1.3 & 34.77 & 739.5 \\
\hline
\end{tabular}

Total $\mathrm{C}$, total $\mathrm{N}$ and total $\mathrm{P}$ are based on dry weight basis.

\subsubsection{Sample collection and preparation}

Changes in the chemical characteristics, stability and maturity of the composting mixture with time were studied by collecting and analyzing samples at two week's interval for 20 weeks. Sampling was carried out by collecting cores from three depths (top, middle and bottom from a height of $0.9 \mathrm{~m}$ for compost and of $0.7 \mathrm{~m}$ for vermicompost) and subsamples were joined and thoroughly mixed to form composite.

\subsubsection{Analysis of compost and vermicompost samples}

Moisture content of samples was determined as weight loss upon drying at $105{ }^{\circ} \mathrm{C}$ in an oven for $24 \mathrm{~h}$. All data are expressed on a dry weight basis. Electrical conductivity (EC) and $\mathrm{pH}$ were determined from 1:10 (w/v) water extract. Total carbon and $\mathrm{N}$ were determined by automated dry-combustion chromatography on an elemental analyzer (Elementar GmbH, Hanau, Germany). To measure phosphorus; $5 \mathrm{~g}$ of samples were extracted with $100 \mathrm{ml}$ and analyzed for total phosphorus using Olsen method $(0.5 \mathrm{M}$ $\mathrm{NaHCO}_{3}, \mathrm{pH}$ 8.5) (Olsen et al., 1954).

In order to measure mineral $\mathrm{N}$; fresh samples were used for determination of $\mathrm{NO}_{3}-\mathrm{N}$ and $\mathrm{NH}_{4}-\mathrm{N}$ using micro-Kjeldahl distillation methods; mineral nitrogen was calculated as addition of ammonium and nitrate. Briefly, $100 \mathrm{~g}$ of each sample was extracted with 125 $\mathrm{ml}$ of $2 \mathrm{M} \mathrm{KCl}$ and $0.01 \mathrm{M} \mathrm{CaCl}_{2}$, respectively. $\mathrm{KCl}$ and $\mathrm{CaCl}_{2}$ extracts were analyzed for nitrate and ammonium, respectively, using steam distillation method (Bremner \& Keeney, 1965). 
To measure water-soluble phosphorus (WSP); $5 \mathrm{~g}$ of material was suspended in $50 \mathrm{ml}$ distilled water in $250 \mathrm{ml}$ Erlenmayer flask at $60^{\circ} \mathrm{C}$ (solid to water ratio of 1:10 w/v), shaken for $1 \mathrm{hr}$ on horizontal shaker at $160 \mathrm{rpm}$, extracted at room temperature (Benitez et al., 2002). The suspensions were filtered through Whatman No. 1 filter paper and then analyzed by the colorimetric method with molybdenum. All results reported in the texts are the means of determinations made on four replicates.

\subsection{Statistical analysis}

Data were statistically analyzed with the SAS System for Windows. Analysis of variance (ANOVA) was used to determine if there were composting or vermicomposting effects; if so, the differences were separated using the Least Squares Mean (LSD) at a probability level of 0.05, unless otherwise stated, using SAS 9.0 (SAS Institute, 2000). Multiple correlations between physiochemical parameters were also calculated.

\subsection{Results and discussion}

The evolution during composting process of the physiochemical parameters of each measured substrate within selected times is presented in the following parts.

\subsubsection{Total nitrogen and carbon}

Total $\mathrm{N}$ of vermicompost was $1.6 \%$ after 6 weeks of decomposition, significantly reduced to $1.4 \%$ within the following 4 weeks, further declined to 1.3 in week 16 , and slightly increased to 1.4 in the final product (after 20 weeks) (Fig 4.1).

Total $\mathrm{N}$ of the compost was $1.4 \%$ within the first 6 weeks, declined to 1.3 in the following 4 weeks, further decreased to $1.2 \%$ in week 16, and remained relatively constant up the end the composting period (Fig 4.1).

The significant $(P<0.05)$ reduction of total $\mathrm{N}$ in both compost and vermicompost over time was mainly attributed to the release of nitrogen in the mineral form as a consequence of decomposition. Nitrogen losses could be either in the form of ammonia from compost or both ammonium and nitrate with leaching from the vermicompost. The reduction in total $\mathrm{N}$ during decomposition was reported earlier by Goyal et al. (2005) who attributed the reduction to the $\mathrm{N}$ losses. This loss could be due to $\mathrm{NH}_{3}$ volatilization because of the $\mathrm{pH}$ value and/or $\mathrm{N}$ uptake into the earthworm biomass in case of 
vermicomposting, as suggested by Hartenstein and Hartenstein (1981). These results are in contradiction with others reported by Atiyeh et al. (2000a), who observed that total $\mathrm{N}$ contents increased significantly with time associated with overall decrease in the C:N ratio, reflecting a rapid breakdown of carbon compounds by earthworms. The trend of total $\mathrm{N}$ does not allow us to use this value for materials maturity determination.

Total carbon content does provide insight on the substrates' quality, kind and/or stability of the organic matter of these materials. In this study, the measured total carbon after 6 weeks of decomposition was $40.7 \%$ for vermicompost, declined within the following 4 weeks to $29.5 \%$, further reduced to $18.0 \%$, but relatively increased to $20.4 \%$ in the finished product (Fig 4.1).

In compost, total carbon was $37.7 \%$ within the first 6 weeks, reduced to $26.0 \%$ in week 10, further declined to $13.2 \%$, but relatively increased $(17.3 \%$ ) in the final compost (Fig 4.1).

The significant reduction $(P<0.05)$ of total carbon in both compost and vermicompost could be attributed to the evolution of $\mathrm{CO}_{2}$ during decomposition.

Similar result was reported by Parè et al. (1998), who stated the total carbon in animal manure and shredded paper decreased continuously during composting. The strong loss of $\mathrm{C}$ was attributed to the $\mathrm{CO}_{2}$ evolution. 


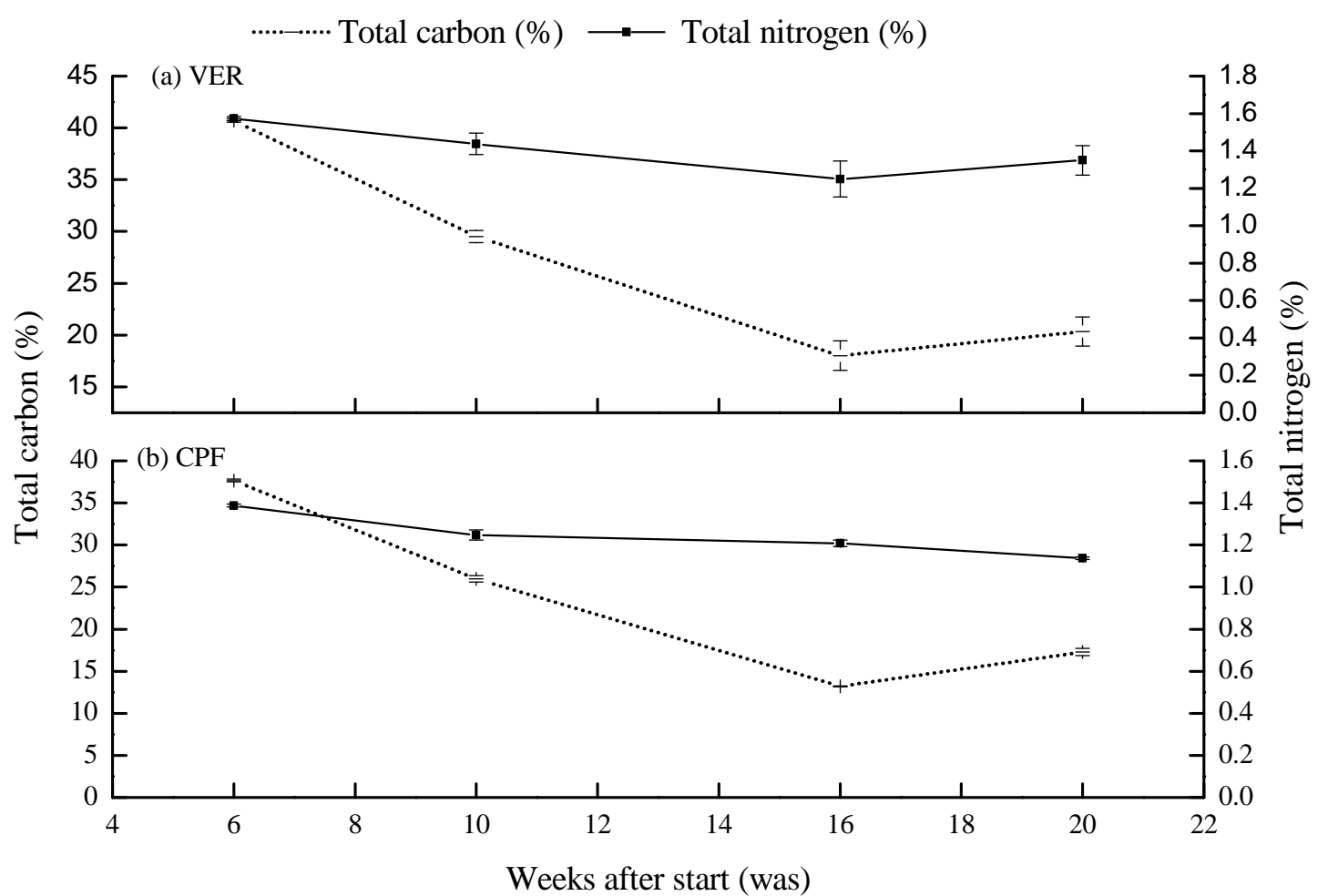

Fig.4.1. Changes in total carbon and nitrogen (\%) during composting and vermicomposting; (a) VER: vermicomposted cotton residues and (b) CPF: composted mixture of cotton residues and FYM. (Bars indicate SEs).

\subsection{2. $\mathrm{pH}$ and electrical conductivity}

The $\mathrm{pH}$ value is one of the most frequent parameters used to characterize compost and vermicompost. In this study, during the first 10 weeks of decomposition, the $\mathrm{pH}$ value of vermicompost was 8.5 , reduced to 8.1 in the following 4 weeks, and further reduced to 7.9 in the finished vermicompost (Fig. 4.2). The $\mathrm{pH}$ value of the compost was 8.5 in the first 6 weeks of decomposition, reduced to 8.3 in week 10, further reduced to 8.0 after 10 weeks, and declined to slightly alkaline (6.6) in the final compost (Fig. 4.2).

During the biodegradation of organic matter, different organic acids are produced during the early stages of organic matter decomposition. The observed reduction in the $\mathrm{pH}$ values was mainly due to the accumulation of such organic acids as a consequence of the organic compounds mineralization (Avnimelech et al., 1996; Chefetz et al., 1998). The type and release of low-molecular weight organic acids depends on the organic substrate 
and decomposition process (e.g. acetic, citric, propionic, formic, butyric, malic acids... etc). Values of the vermicompost after 20 weeks are alkaline and this may indicate stability during this period, while the $\mathrm{pH}$ of the finished compost is slightly alkaline. This may refer to the presence of some organic acids, which suggests that compost may still need additional time. Alkaline $\mathrm{pH}$ values are usually used as indicators of stable composts, because acids that are common phytotoxins (short-chain acids; e.g. acetic, valeric, butyric acids ...etc), are known to be produced during the initial and intermediate stages of decomposition and, therefore, are not expected to be present in mature and stable composts (Mathur et al., 1993) because of loss via decomposition (Miyittah \& Inubushi, 2003).

In this study, the measured values of compost and vermicompost are within the optimum range (5.5 - 8.0) reported by Inbar et al. (1993). These results are also in agreement with the results of Benito et al. (2003), who stated an increase in $\mathrm{pH}$ values to around 8 in the finished materials, and again are consistent with the findings of Iannotti et al. (1994) who reported an increase in the $\mathrm{pH}$ value using municipal solids waste compost. Avnimelech (1996) reported similar results and further explained that $\mathrm{pH}$ changes were caused by decomposition of organic acids. 
Electrical conductivity (EC) as an indirect measure of total ions concentration; is another parameter to be considered as an index for these products. In this study, the sum of soluble ions in the water extracts, as indicated by EC measurements, increased with time from 0.26 to 2.96 (mainly due to the FYM) in the compost and from 0.58 to $1.62 \mathrm{dSm}^{-1}$ in the vermicompost during the process due, in part, to the release of the easily decomposable compounds into the solution (Saviozzi et al., 1987). During the composting time there was significant change in EC $(P \leq 0.0001)$ occurred in both materials. Significant differences were found between values observed during the first six weeks and that measured after 20 weeks (Fig. 4.2), this result is in agreement with results reported by Morel et al. (1985). Increase of conductivity during composting was also reported in other studies and attributed to the effect of salt concentration as a consequence of the degradation of the organic matter fraction (Iglesias Jimenez et al., 1986; Negro et al., 1999) The low levels of soluble salts measured in the vermicompost was previously reported by Albanell et al.(1988) who suggested that vermicompost may be suitable for both soil amendments and for plant growth. They used the same mixtures of industrial cotton residues and sheep manure in the presence and absence of earthworms.

Electrical conductivity values of compost and could be considered as normal, and the values are within the optimum range (maximum value of $4 \mathrm{dS} / \mathrm{m}$ ) suggested by Lasaridi et al. (2006). The threshold value is considered tolerable by plants of medium sensitivity for salinity, and excessive soluble salt may adversely affect plant and crops. High values of EC can sometimes make a certain wastes unsuitable for their use as organic amendments (Pascual et al., 1997). Iannotti et al. (1994) found a strong inhibition of seeds germination by water extracts of municipal solid wastes compost; thus, authors attributed this behavior to the high compost salinity.

The changes of $\mathrm{pH}$ and EC with decomposition encouraged Avnimelech (1996) to suggest those simple parameters as good indicators of stability, and Wu et al. (2000) suggested them to be used to monitor stabilization and maturation. 

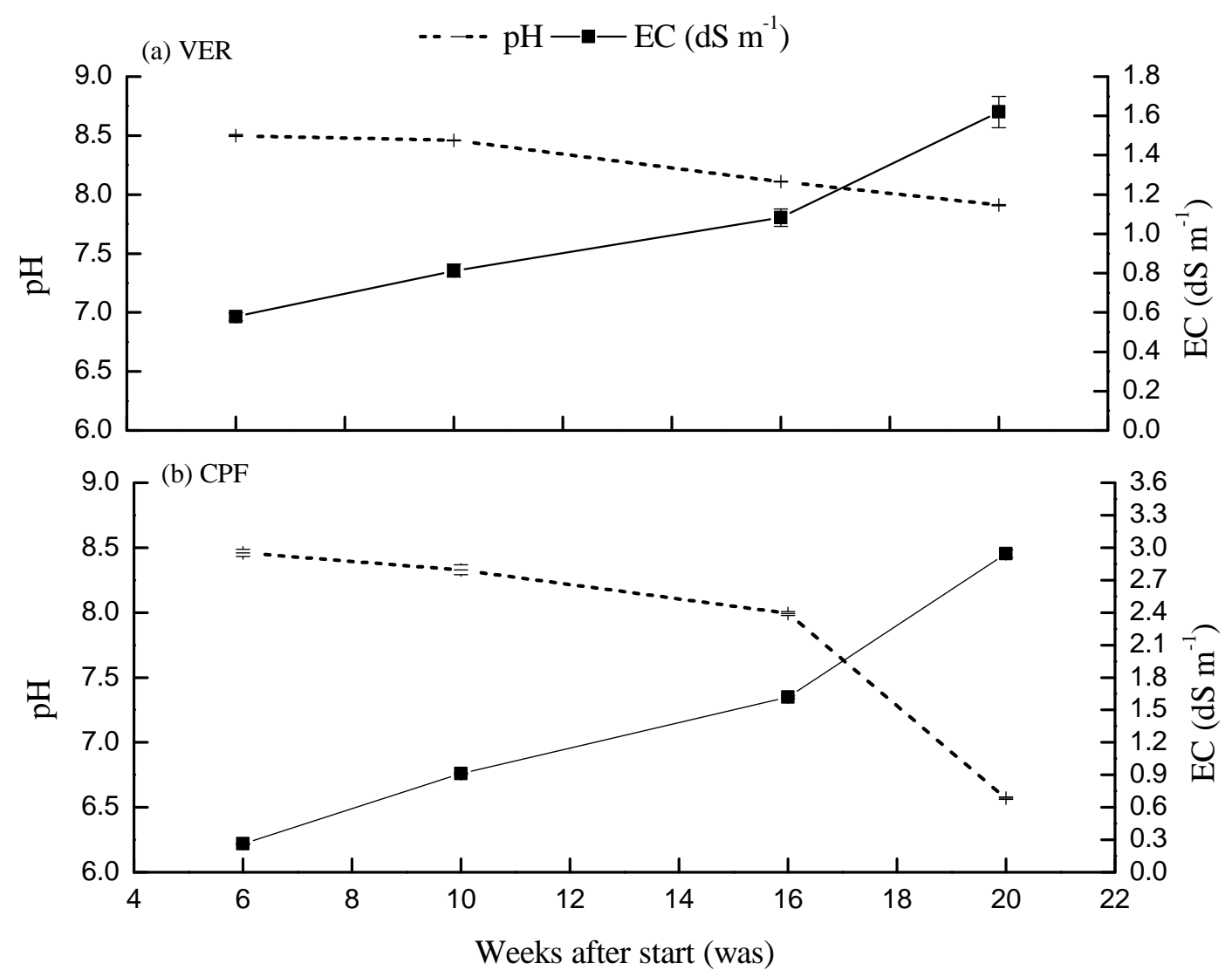

Fig.4.2. Changes in $\mathrm{pH}$ and electrical conductivity during composting and vermicomposting; (a) VER: vermicomposted cotton residues and (b) CPF: composted mixture of cotton residues and FYM. (Bars indicate SEs). 


\subsubsection{Ammonium, nitrate and total mineral nitrogen}

In this experiment, the concentration of $\mathrm{NH}_{4}-\mathrm{N}$ in the vermicompost was around $37 \mathrm{mg}$ $\mathrm{kg}^{-1}$ within the first 10 weeks, dropped to about $17.8 \mathrm{mg} \mathrm{kg}^{-1}$ within the following 6 weeks, and further reduced to $16.7 \mathrm{mg} \mathrm{kg}^{-1}$ in the finished material (Fig 4.3A). While, the concentration of $\mathrm{NO}_{3}-\mathrm{N}$ within the 10 weeks was above $86.8 \mathrm{mg} \mathrm{kg}^{-1}$, reduced to $74.9 \mathrm{mg}$ $\mathrm{kg}^{-1}$, but significantly $(P<0.05)$ increased to $160 \mathrm{mg} \mathrm{kg}^{-1}$ and remained constant in the finished material (Fig 4.3B). Reduction in $\mathrm{NH}_{4}-\mathrm{N}$ over time associated with increase in $\mathrm{NO}_{3}-\mathrm{N}$ may indicate the conversion of $\mathrm{NH}_{4}-\mathrm{N}$ into $\mathrm{NO}_{3}-\mathrm{N}$. Decreasing the amounts of $\mathrm{NH}_{4}-\mathrm{N}$ coupled with increases in $\mathrm{NO}_{3}-\mathrm{N}$ concentration towards the end of vermicomposting suggests that substrate underwent an intensive biological decomposition.

The enhancement of nitrate could be due to the increase in the activity of nitrifying bacteria. Earthworm has a great impact on nitrogen transformation, by enhancing nitrogen mineralization via ameliorating conditions that favors the nitrification process, resulting in the rapid conversion of $\mathrm{NH}_{4}-\mathrm{N}$ into $\mathrm{NO}_{3}-\mathrm{N}$ (Atiyeh et al., 2000a). Same conclusion was reported by Parè et al. (1998) who considered the conversion of $\mathrm{NH}_{4}-\mathrm{N}$ into $\mathrm{NO}_{3}-\mathrm{N}$ over time as an indication of material's maturity. Similar results were reported by Hand et al. (1988) who found that earthworms in cow slurry increased the $\mathrm{NO}_{3}-\mathrm{N}$ content of the substrate.

Confirming the previous point, the ratio of $\mathrm{NH}_{4}-\mathrm{N}: \mathrm{NO}_{3}-\mathrm{N}$ decreased during this process and the value of the finished product $(0.10)$ is below 0.16 , the maximum ratio suggested by Bernal et al. (1998b) for mature compost.

The concentration of $\mathrm{NH}_{4}-\mathrm{N}$ and $\mathrm{NO}_{3}-\mathrm{N}$ in the compost reduced with time. The concentration of $\mathrm{NH}_{4}-\mathrm{N}$ in the compost was above $159.4 \mathrm{mg} \mathrm{kg}^{-1}$ within the first 10 weeks, reduced to $157.8 \mathrm{mg} \mathrm{kg}^{-1}$ in week 10 , significantly $(P<0.05)$ declined to 138.9 $\mathrm{mg} \mathrm{kg}{ }^{-1}$ in week 16 , and remained relatively constant over time up to the end of the composting (Fig 4.3C). Same trend was observed for the concentration of $\mathrm{NO}_{3}-\mathrm{N}$; after the first 6 weeks of decomposition, the concentration was $366.9 \mathrm{mg} \mathrm{kg}^{-1}$, significantly $(P$ 
$<0.05)$ dropped to $157.1 \mathrm{mg} \mathrm{kg}^{-1}$, and further reduced to $88.7 \mathrm{mg} \mathrm{kg}^{-1}$, in week 16 , and remained constant through the following 4 weeks (Fig 4.3D).

The content of $\mathrm{NO}_{3}-\mathrm{N}$ during the first six weeks was higher than the $\mathrm{NH}_{4}-\mathrm{N}$, this may indicate the conversion process of $\mathrm{NH}_{4}-\mathrm{N}$ into $\mathrm{NO}_{3}-\mathrm{N}$ during this time, but there after the reverse occurred throughout the experiment period. The reduction of both $\mathrm{NH}_{4}-\mathrm{N}$ and $\mathrm{NO}_{3}-\mathrm{N}$ may be attributed to the loss of $\mathrm{NH}_{4}-\mathrm{N}$ in the form of $\mathrm{NH}_{3}$ as a result of the high $\mathrm{pH}$ (above 8) (Ekinci et al., 2000) during the composting associated with the low activity of nitrifiers. Nitrification is well known to be inhibited at temperatures above $40^{\circ} \mathrm{C}$ (Alexander, 1977b) and the temperature of the compost especially during the thermophilic phase is always above this value.

The loss of the $\mathrm{NO}_{3}-\mathrm{N}$ could be through denitrification associated with the presence of anaerobic or microaerophilic pockets in the mixture. Another explanation could be that $\mathrm{NH}_{4}-\mathrm{N}$ was assimilated by the heterotrophic microorganisms that predominate during the thermophilic phase, suppressing its conversion to $\mathrm{NO}_{3}-\mathrm{N}$ or volatilization as $\mathrm{NH}_{3}$ (Bishop \& Godfrey, 1983; Parè et al., 1998).

Although $\mathrm{NH}_{4}-\mathrm{N}$ and $\mathrm{NO}_{3}-\mathrm{N}$ decreased with time, the trend of $\mathrm{NH}_{4}-\mathrm{N}: \mathrm{NO}_{3}-\mathrm{N}$ ratio is exactly the reverse to that noticed in vermicompost, and the $\mathrm{NH}_{4}-\mathrm{N}: \mathrm{NO}_{3}-\mathrm{N}$ value of the finished compost (1.57) is extremely far above the threshold value for the mature compost (0.16) .(Bernal et al., 1998b)

Ammonium content can be considered as an inhibitory factor (Findenegg, 1987; Katayama et al., 1985), a high level of $\mathrm{NH}_{4}-\mathrm{N}$ indicates unstabilized material while the nitrate is considered as a sign of maturity therefore, the increased $\mathrm{NO}_{3}-\mathrm{N}$ concentration associated with the decrease in NH4-N concentration in vermicompost over time may be used as valid indicator of substrate's maturity (Chefetz et al., 1998; Inbar et al., 1993). This trend was ideally obtained in the vermicompost, where, NH4-N (0.002) is below 0.04\% (Spohn, 1978; Zucconi \& De Bertoldi, 1987), This result is further supported with the ratio of $\mathrm{NH}_{4}-\mathrm{N}: \mathrm{NO}_{3}-\mathrm{N}$ as additional criterion. Unfortunately, these criteria (reduction in $\mathrm{NH}_{4}-\mathrm{N}$, increase in $\mathrm{NO}_{3}-\mathrm{N}$, and the value of $\mathrm{NH}_{4}-\mathrm{N}: \mathrm{NO}_{3}-\mathrm{N}$ ratio) are not applicable 
for the compost, because the ratio of $\mathrm{NH}_{4}-\mathrm{N}: \mathrm{NO}_{3}-\mathrm{N}$ is far above the threshold value due fluctuations in the $\mathrm{NH}_{4}-\mathrm{N}$ and $\mathrm{NO}_{3}-\mathrm{N}$ during composting.

Mineral nitrogen as a result of ammonium and nitrate was affected by their trend in compost and vermicompost. In the vermicompost, the measured mineral $\mathrm{N}$ was $124.5 \mathrm{mg}$ $\mathrm{kg}^{-1}$ after 6 weeks of processing, decreased to $111.9 \mathrm{mg} \mathrm{kg}^{-1}$ after 10 weeks; significantly $(P<0.05)$ increased to $178.0 \mathrm{mg} \mathrm{kg}^{-1}$ after 16 weeks, and remained relatively constant thereafter up to the end of the study (Fig. 4.4). High mineral nitrogen over time is a result of the mineralization of organic-N compounds, thus reflecting organic matter transformation during which $\mathrm{NH}_{4}-\mathrm{N}$ concentration reduced led to increases of $\mathrm{NO}_{3}-\mathrm{N}$ through nitrification (Bernal et al., 1998b). Increase of available nutrients (e.g. mineralN) has been described in previous works and is probably inherent to earthworm activity (Tognetti et al., 2005; Zhang et al., 2000).

In compost, the content of mineral-N was significantly high $\left(527 \mathrm{mg} \mathrm{kg}^{-1}\right)(P<0.05)$ during the first 6 weeks, then significantly decreased to $228.1 \mathrm{mg} \mathrm{kg}^{-1}$ in week 16 . The concentration of mineral $\mathrm{N}$ did not significantly $(P>0.05)$ change between week 16 and week 20 (Fig 4.4). The reduction of mineral-N was mainly due to the reduction in both $\mathrm{NH}_{4}-\mathrm{N}$ and $\mathrm{NO}_{3}-\mathrm{N}$ over time. The possible explanation for this, could be to loss of $\mathrm{NH}_{4}-$ $\mathrm{N}$ in the form of $\mathrm{NH}_{3}$ as a result of the high $\mathrm{pH}$ (Ekinci et al., 2000) associated with the low activity of nitrifiers (Alexander, 1977b; Tognetti et al., 2007). 

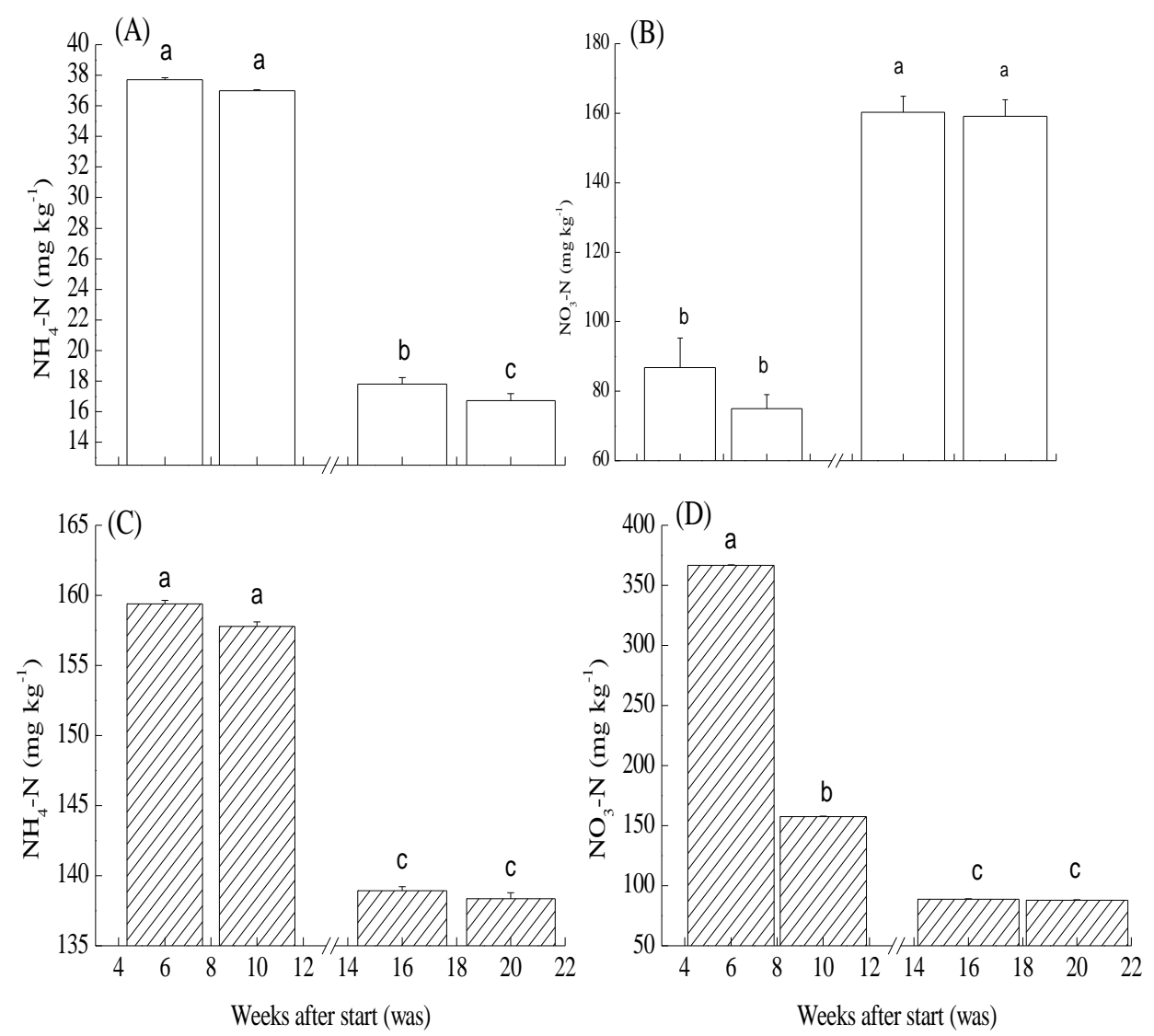

Fig. 4.3. Changes in $\mathrm{NH}_{4}-\mathrm{N}$ and $\mathrm{NO}_{3}-\mathrm{N}\left(\mathrm{mg} \mathrm{kg}^{-1}\right)$ over time in vermicomposting (A and $\left.\mathrm{B}\right)$ and composting ( $\mathrm{C}$ and $\mathrm{D})$ (means \pm standard error). Means within the same graph followed by the same letter (s) are not significantly different at $P \geq 0.05$. 


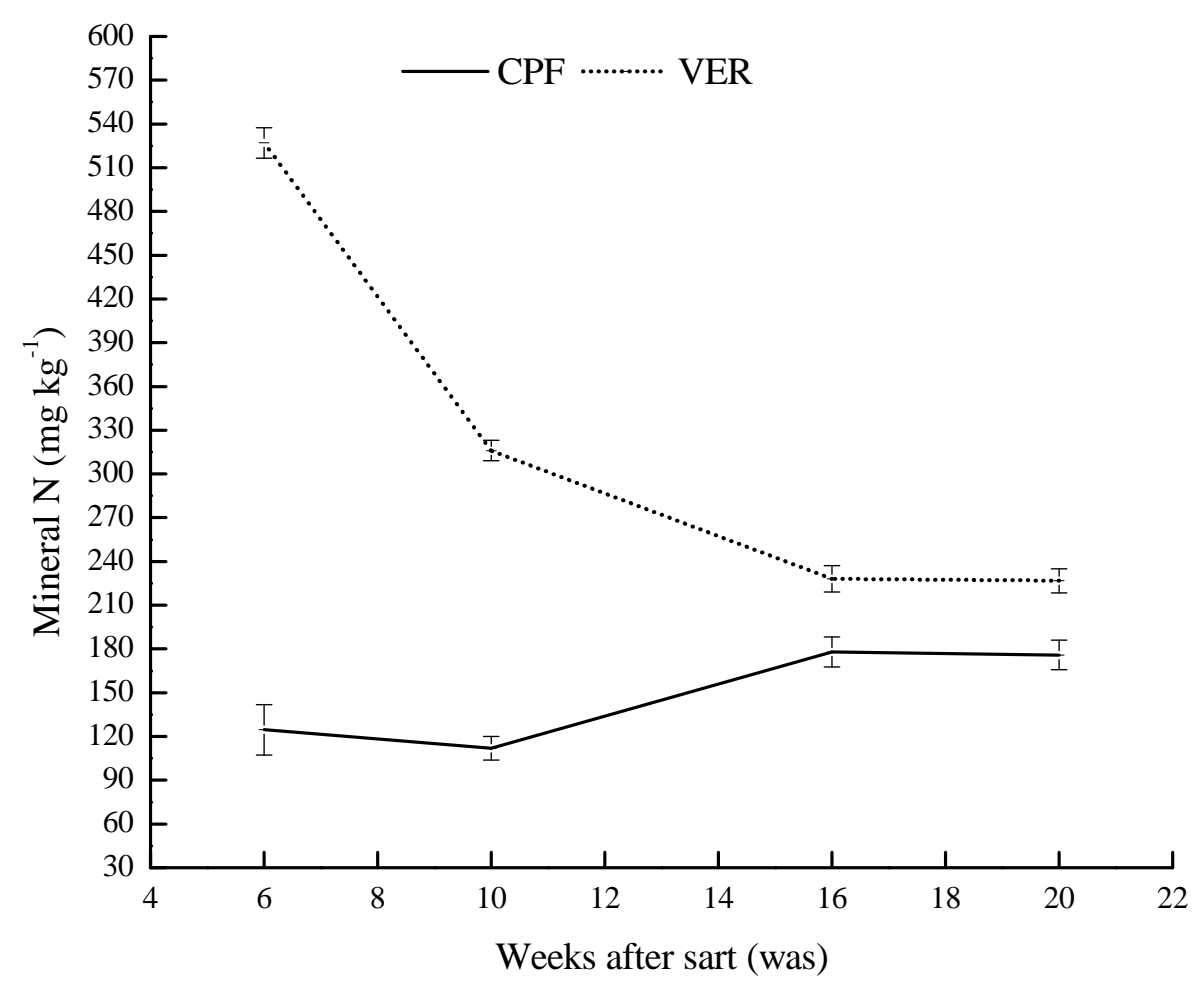

Fig. 4.4. Changes in mineral-N over time in the compost and vermicompost (Means $\pm \mathrm{SE}$ ).

\subsubsection{Carbon to nitrogen ratio $(\mathrm{C}: \mathrm{N})$}

Carbon to nitrogen ratio is frequently used as an index of maturity. It is known that microorganisms which act in the composting process use about 30 parts carbon to one of nitrogen, which suggests that it would be convenient to start the composting with a $\mathrm{C}: \mathrm{N}$ ratio of around 30. As these microorganism consume the most labile carbon fractions, the $\mathrm{C}: \mathrm{N}$ ratio falls until it reaches values at the end of maturity of between 15 and 20 . When the waste to be composted has a high $\mathrm{C}: \mathrm{N}$ ratio, the value of this ratio can be used as an indicator of maturity, and the compost can be considered mature when the ratio reaches the above mentioned values (15-20) (Garcia et al., 1992). However, the C:N ratio alone is not a reliable stability indicator, due to a large variability in values (Epstein, 1997) and, since the $\mathrm{C}: \mathrm{N}$ ratio of the starting material has to be always accounted for. 
In this study, the initial $\mathrm{C}: \mathrm{N}$ ratio (zero time) were 41 and 47 for composting and vermicomposting, respectively. As decomposition progressed due to losses of carbon mainly as $\mathrm{CO}_{2}$, the carbon content of the decomposable material decreased with time.

For the vermicompost, the value of $\mathrm{C}: \mathrm{N}$ significantly $(P \leq 0.05)$ decreased to 25.8 after 6 weeks, further reduced to 20.2, and decreased later but remained relatively constant for the rest of the vermicomposting time (Fig. 4.5).

The $\mathrm{C}: \mathrm{N}$ values of the compost, significantly $(P \leq 0.05)$ declined from the initial value to 27.4 after 6 weeks of composting, further reduced to 20.2 in week 10, and reduced later to 11.4 during the following 4 weeks but increased to 15.4 at the end of the composting time (Fig. 4.5).

For maturity evaluation to define the degree of the organic matter decomposition, different $\mathrm{C}: \mathrm{N}$ values based on the characteristics of organic materials, have been proposed. For instance, Garcia et al. (1992), reported a range of 15-20 as an acceptable range for maturity. The final value of $>12$ has been suggested by Iglesia-Jimènez and Pérez-García (1992), Poincelot (1974), and Golueke (1977b). A ratio below 20 has also been considered as indication of an acceptable maturity (Goyal et al., 2005). In this study, the $\mathrm{C}: \mathrm{N}$ ratio of the final vermicompost and compost are 15.2 and 15.4 respectively, both values are within the suggested maturity ranges. In general, this value may be used as a reliable index of maturity, however, C:N ratio cannot be used as a single limit for judging compost maturity when different raw materials were used (Charest et al., 2004; Huang et al., 2001). 


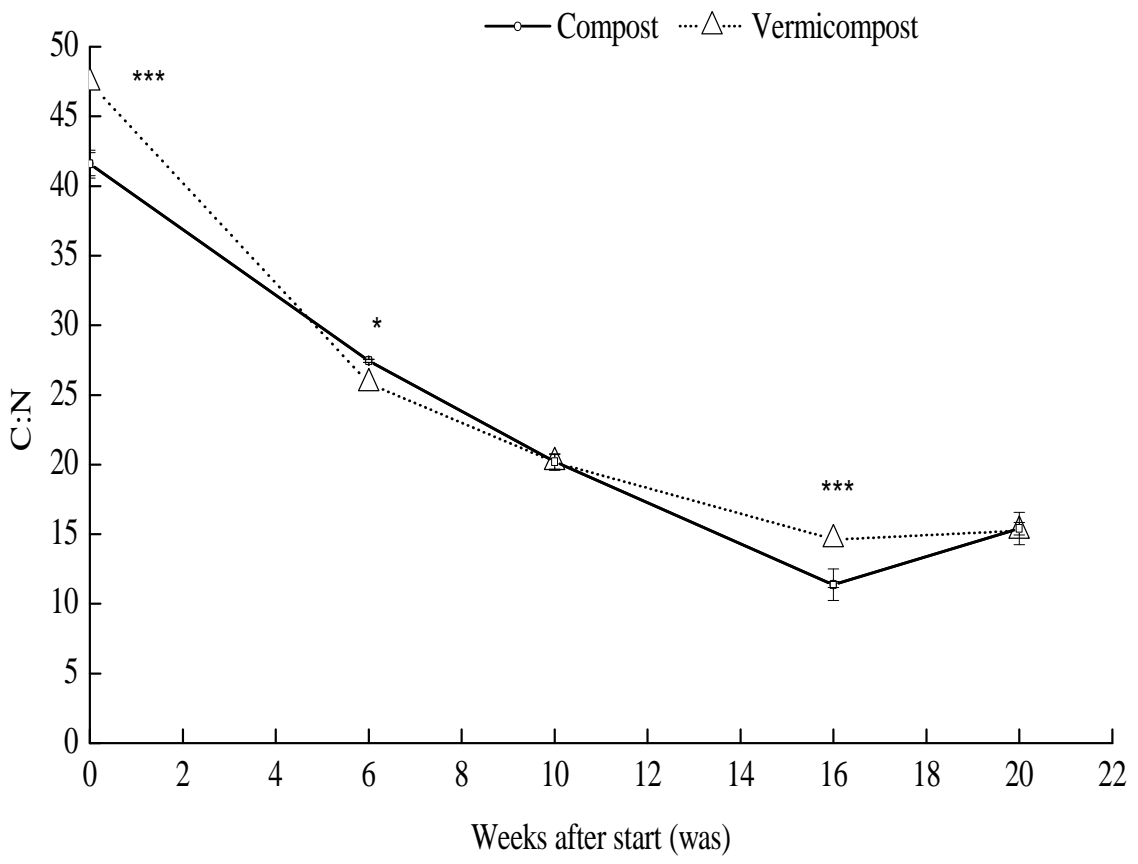

Fig. 4.5. Changes in $\mathrm{C}: \mathrm{N}$ ratio with time in the compost and vermicompost products. Means within the same date followed by $*$ and $* * *$ are significantly different at $P \leq 0.05$ and $P \leq 0.001$, respectively. 
Sufficient information has been generated on the decomposition of legume crop residues and cereals (Angers \& Recous, 1997; Collins et al., 1990). However, such information on the decomposition pattern of cotton residues and description of decomposer communities is available to a limited extent (Blaise \& Bhaskar, 2003; Lachnicht et al., 2004; Torbert et al., 1995). Content and nature of the organic matter are essential for determining product quality (Grigatti et al., 2004; He et al., 1995).

Cotton residues are considered as woody components especially the stalk parts. Residues are characterized with $49.1 \%$ total $\mathrm{C}, 1.68 \%$ total $\mathrm{N}$, and $29.2 \mathrm{C}: \mathrm{N}$, as well as cell wall components such as lignin, cellulose, and hemicellulose are $21.0 \%, 36.8 \%$, and $19.0 \%$, respectively The cell compounds are well documented as microbially resistant and slow down decomposition (Torbert et al., 1995).

In an attempt to give some information about decomposed organic materials and to find simple and practical criteria for maturity evaluation, which is commonly used to define the degree of organic matter decomposition, correlations between physiochemical parameters were done. Although, maturity refers to the degree of decomposition of phytotoxic organic substances produced during the active composting stage (Wu et al., 2000), no single parameter can be used as a suitable indicator of maturity of composts and vermicomposts prepared from different materials (Goyal et al., 2005). Therefore, the content of the metabolic products during decomposition, such as $\mathrm{NH}_{4}-\mathrm{N}, \mathrm{NO}_{3}-\mathrm{N}, \mathrm{EC}$, as an indirect measure of the soluble nutrients, $\mathrm{C}: \mathrm{N}$, and $\mathrm{pH}$, which better described the decomposition processes, were correlated.

For the vermicompost, the correlation coefficients between C:N ratio and $\mathrm{NH}_{4}-\mathrm{N}, \mathrm{NO}_{3}-\mathrm{N}$, $\mathrm{pH}$ and EC were $r=0.86(P<0.01),-0.79(P<0.01), 0.91(P<0.01)$ and $-0.77(P<0.01)$, respectively. Ammonium-N concentration was also well correlated to $\mathrm{NO}_{3}-\mathrm{N}(r=-0.95, P$ $<0.01$ ) (Table 4.2), this negative correlation indicated that material underwent active biological decomposition; this point is supported with the value of $\mathrm{NH}_{4}-\mathrm{N}: \mathrm{NO}_{3}-\mathrm{N}$ ratio. The significant negative correlation between $\mathrm{C}: \mathrm{N}$ ratio and $\mathrm{NO}_{3}-\mathrm{N}(r=-0.79, P<0.01)$ and $\mathrm{C}: \mathrm{N}$ and $\mathrm{NH}_{4}-\mathrm{N}$ mirrored the trend of vermicomposting. 
Same correlations were performed for the compost; the correlation coefficients between $\mathrm{C}: \mathrm{N}$ ratio and $\mathrm{NH}_{4}-\mathrm{N}, \mathrm{NO}_{3}-\mathrm{N}, \mathrm{pH}$ and $\mathrm{EC}$ were $r=0.88(P<0.01), 0.94(P<0.01), 0.59$ $(P=0.02)$ and $-0.72(P<0.01)$, respectively. Ammonium-N concentration was also well correlated with $\mathrm{NO}_{3}-\mathrm{N}(r=0.80, P<0.01)$. This correlation is reverse to that observed in the vermicompost (Table 4.2).

The significant positive correlation between $\mathrm{C}: \mathrm{N}$ ratio and $\mathrm{NO}_{3}-\mathrm{N}(r=0.94, P<0.01)$, suggesting that additional processing time is needed. Additionally, $\mathrm{NO}_{3}-\mathrm{N}$ parameter is not applicable for this process as stated previously. This note is further supported with the high value of the $\mathrm{NH}_{4}-\mathrm{N}: \mathrm{NO}_{3}-\mathrm{N}$ ratio (1.57) which is far above the threshold value reported for the mature compost. However, the positive correlation between $\mathrm{NH}_{4}-\mathrm{N}$ and $\mathrm{C}: \mathrm{N}$ ratio $(r=0.88, P<0.01)$, indicates the progress in decomposition.

A parameter to be considered as a suitable index of maturity must be a good indicative of the progress in decomposition and maturation, and its value should change in a similar way in all samples; in other words, similar values must be obtained for all mature composts regardless of the type of initial raw material (Garcia et al., 1991). These specifications could be applied for the $\mathrm{C}: \mathrm{N}$ ratio of this study. However, this index can be used as recommended when combined with other parameters such as $\mathrm{NH}_{4}-\mathrm{N}, \mathrm{NO}_{3}-\mathrm{N}, \mathrm{pH}$ and EC. 


\subsection{Conclusions}

Analyses of the two organic amendments (compost and vermicompost) have shown a broad variation in numbers of physiochemical parameters; $\mathrm{pH}$, total $\mathrm{N}$, total $\mathrm{C}, \mathrm{C}: \mathrm{N}$ ratio, $\mathrm{EC}$, and mineral contents (Table 4.4). The C:N ratio, EC, $\mathrm{pH}$ and $\mathrm{NH}_{4}-\mathrm{N}: \mathrm{NO}_{3}-\mathrm{N}$ consistently reflected the trend of the decomposition during the composting and vermicomposting. It is highly desirable that a general index of maturity, which will be independent of the source of material or decomposition condition and technique, be identified for the benefit of researcher and compost producer alike.

This study supports previous work that reduction in C:N ratio with time can be taken as a reliable parameter to mirror the progress in decomposition especially when combined with other parameters such as $\mathrm{NO}_{3}-\mathrm{N}, \mathrm{NH}_{4}-\mathrm{N}, \mathrm{pH}$ and $\mathrm{EC}$. Values of the parameters obtained from this study are within the common ranges advised for the mature materials reported in other studies (Table 4.3).

The correlation between C:N ratio and $\mathrm{NO}_{3}-\mathrm{N}$, calculated from the vermicompost data, clearly reflects progress of the decomposition which is further supported with the value of $\mathrm{NH}_{4}-\mathrm{N}_{\mathrm{NO}}-\mathrm{N}$ ratio. This trend was not applicable for the compost data because the content of $\mathrm{NO}_{3}-\mathrm{N}$ is contradictory to what normally stated in the literature, additionally, the value of the $\mathrm{NH}_{4}-\mathrm{N}: \mathrm{NO}_{3}-\mathrm{N}$ ratio is above the threshold value.

This study suggested that $\mathrm{C}: \mathrm{N}$ ratio, $\mathrm{NH}_{4}-\mathrm{N}, \mathrm{NO}_{3}-\mathrm{N}, \mathrm{pH}$, and $\mathrm{EC}$ can be used as practical indexes for vermicompost, while $\mathrm{C}: \mathrm{N}$ ratio, $\mathrm{NH}_{4}-\mathrm{N}, \mathrm{pH}$, and $\mathrm{EC}$ for compost. 
Table 4.2: Correlation coefficients of the physiochemical parameters of compost and vermicompost

\begin{tabular}{|c|c|c|c|c|c|c|c|c|c|c|}
\hline \multicolumn{6}{|c|}{ Vermicompost } & \multicolumn{5}{|c|}{ Compost } \\
\hline & $\mathrm{C}: \mathrm{N}$ & $\mathrm{NH}_{4}-\mathrm{N}$ & $\mathrm{NO}_{3}-\mathrm{N}$ & $\mathrm{pH}$ & $\mathrm{EC}$ & $\mathrm{C}: \mathrm{N}$ & $\mathrm{NH}_{4}-\mathrm{N}$ & $\mathrm{NO}_{3}-\mathrm{N}$ & $\mathrm{pH}$ & $\mathrm{EC}$ \\
\hline $\mathrm{C}: \mathrm{N}$ & 1.0 & $0.86 * *$ & $-0.79 * *$ & $0.91 * *$ & $-0.77 * *$ & 1.0 & $0.88 * *$ & $0.94 * *$ & $0.59 *$ & $-0.71 * *$ \\
\hline $\mathrm{NH}_{4}-\mathrm{N}$ & & 1.0 & $-0.95 * *$ & $0.92 * *$ & $-0.87 * *$ & & 1.0 & $0.80 * *$ & $0.79 * *$ & $-0.87 * *$ \\
\hline $\mathrm{NO}_{3}-\mathrm{N}$ & & & 1.0 & $-0.84 * *$ & $0.75^{* *}$ & & & 1.0 & $0.70 * *$ & $-1.80^{* *}$ \\
\hline $\mathrm{pH}$ & & & & 1.0 & $-0.92 * *$ & & & & 1.0 & $-0.98 * *$ \\
\hline $\mathrm{EC}$ & & & & & 1.0 & & & & & 1.0 \\
\hline
\end{tabular}

ns: non-significant $(P>0.05),{ }^{*} P \leq 0.05$, and $* * P \leq 0.01$; EC: electrical conductivity. 
Table 4.3. Main characteristics of the final compost and vermicompost compared to the common ranges

\begin{tabular}{|c|c|c|c|c|}
\hline Parameter & Vermicompost & Compost & $\begin{array}{l}\text { Common range or } \\
\text { threshold value }\end{array}$ & References \\
\hline $\mathrm{pH}$ & 7.9 & 6.6 & $6-8$ & $\begin{array}{l}\text { Negro et al., 1999; Sullivan \& Miller, 2000; Saebo \& } \\
\text { Ferrini, } 2006\end{array}$ \\
\hline $\mathrm{C}: \mathrm{N}$ ratio & 15.2 & 15.4 & $\begin{array}{l}<12 \\
<20 \\
10-25 \\
15-20\end{array}$ & $\begin{array}{l}\text { Bernal et al., 1998a; Igleisias-Jimènez and Pèrez- } \\
\text { Garcia, } 1992 \\
\text { Zucconi \& De Bertoldi, 1987; Stevenson, } 1994 \\
\text { Negro et al., 1999; Sullivan \& Miller, 2000; Saebo \& } \\
\text { Ferrini, } 2006 \\
\text { Garcia et al } 1998\end{array}$ \\
\hline Total N (\%) & 1.4 & 1.1 & $\begin{array}{l}>0.6 \% \\
0.7-1.0 \%\end{array}$ & $\begin{array}{l}\text { Zucconi et al., } 1987 \\
\text { Negro et al., 1999; Sullivan \& Miller, 2000; Saebo \& } \\
\text { Ferrini, } 2006\end{array}$ \\
\hline $\mathrm{EC}(\mathrm{dS} \mathrm{m}-1)$ & 1.6 & 2.9 & 4 & Lasaridi et al., 2006 \\
\hline $\mathrm{NH}_{4}-\mathrm{N}\left(\mathrm{mg} \mathrm{kg}^{-1}\right)$ & 16.7 & 138.4 & $<400$ & Bernal et al., 1998a \\
\hline $\mathrm{NH}_{4} / \mathrm{NO}_{3}$ & 0.1 & 1.6 & $<0.16$ & Bernal et al., 1998a; Contreras-Ramos et al., 2005. \\
\hline
\end{tabular}


Table 4.4: ANOVA table of the compost and vermicompost physiochemical parameters

\begin{tabular}{|c|c|c|c|c|c|c|}
\hline Source & Dependent Variable & $\begin{array}{l}\text { Sum of } \\
\text { Squares }\end{array}$ & $\mathrm{df}$ & $\begin{array}{l}\text { Mean } \\
\text { Square }\end{array}$ & $\mathrm{F}$ & Sig. \\
\hline \multirow[t]{9}{*}{ Corrected Model } & $\%$ Carbon & 2790.47 & 7 & 398.64 & 169.55 & 0.000 \\
\hline & $\%$ Nitrogen & 0.56 & 7 & 0.08 & 8.02 & 0.000 \\
\hline & $\mathrm{CN}$ & 897.73 & 7 & 128.25 & 72.77 & 0.000 \\
\hline & $\mathrm{NH}_{4}-\mathrm{N}$ & 120956.88 & 7 & 17279.55 & 39082.23 & 0.000 \\
\hline & $\mathrm{NO}_{3}-\mathrm{N}$ & 257810.05 & 7 & 36830.01 & 556.92 & 0.000 \\
\hline & Mineral- N & 504053.33 & 7 & 72007.62 & 1002.99 & 0.000 \\
\hline & $\mathrm{NH}_{4}-\mathrm{N}: \mathrm{NO}_{3}-\mathrm{N}$ & 9.90 & 7 & 1.41 & 1021.00 & 0.000 \\
\hline & $\mathrm{pH}$ & 13.89 & 7 & 1.98 & 1428.02 & 0.000 \\
\hline & Electrical conductivity & 19.61 & 7 & 2.80 & 487.35 & 0.000 \\
\hline \multirow{9}{*}{$\begin{array}{l}\text { Composting } \\
\text { vermicomposting }\end{array}$} & \% Carbon & 105.13 & 1 & 105.13 & 44.71 & 0.000 \\
\hline & $\%$ Nitrogen & 0.198 & 1 & 0.20 & 20.02 & 0.000 \\
\hline & $\mathrm{CN}$ & 1.02 & 1 & 1.02 & 0.58 & 0.454 \\
\hline & $\mathrm{NH}_{4}-\mathrm{N}$ & 117738.63 & 1 & 117738.63 & 266296.67 & 0.000 \\
\hline & $\mathrm{NO}_{3}-\mathrm{N}$ & 24198.35 & 1 & 24198.35 & 365.91 & 0.000 \\
\hline & Mineral- N & 250276.36 & 1 & 250276.36 & 3486.07 & 0.000 \\
\hline & $\mathrm{NH}_{4}-\mathrm{N}: \mathrm{NO}_{3}-\mathrm{N}$ & 5.82 & 1 & 5.82 & 4203.7 & 0.000 \\
\hline & $\mathrm{pH}$ & 1.36 & 1 & 1.36 & 979.61 & 0.000 \\
\hline & Electrical conductivity & 1.35 & 1 & 1.35 & 235.39 & 0.000 \\
\hline \multirow[t]{9}{*}{ Weeks after start } & $\%$ Carbon & 2681.21 & 3 & 893.74 & 380.13 & 0.000 \\
\hline & $\%$ Nitrogen & 0.32 & 3 & 0.107 & 10.81 & 0.000 \\
\hline & $\mathrm{CN}$ & 871.48 & 3 & 290.49 & 164.83 & 0.000 \\
\hline & $\mathrm{NH}_{4}-\mathrm{N}$ & 3217.10 & 3 & 1072.37 & 2425.44 & 0.000 \\
\hline & $\mathrm{NO}_{3}-\mathrm{N}$ & 66982.83 & 3 & 22327.61 & 337.62 & 0.000 \\
\hline & Mineral- N & 86641.31 & 3 & 28880.44 & 402.27 & 0.000 \\
\hline & $\mathrm{NH}_{4}-\mathrm{N}: \mathrm{NO}_{3}-\mathrm{N}$ & 0.86 & 3 & 0.29 & 205.78 & 0.000 \\
\hline & $\mathrm{pH}$ & 10.23 & 3 & 3.41 & 2453.98 & 0.000 \\
\hline & Electrical conductivity & 15.31 & 3 & 5.10 & 887.65 & 0.000 \\
\hline \multirow[t]{9}{*}{ Interaction } & $\%$ Carbon & 4.14 & 3 & 1.38 & 0.59 & 0.629 \\
\hline & $\%$ Nitrogen & 0.036 & 3 & 0.012 & 1.22 & 0.326 \\
\hline & $\mathrm{CN}$ & 25.23 & 3 & 8.411 & 4.77 & 0.010 \\
\hline & $\mathrm{NH}_{4}-\mathrm{N}$ & 1.14 & 3 & 0.38 & 0.86 & 0.47 \\
\hline & $\mathrm{NO}_{3}-\mathrm{N}$ & 166628.87 & 3 & 55542.96 & 839.89 & 0.000 \\
\hline & Mineral- $\mathrm{N}$ & 167135.67 & 3 & 55711.89 & 776.0 & 0.000 \\
\hline & $\mathrm{NH}_{4}-\mathrm{N}: \mathrm{NO}_{3}-\mathrm{N}$ & 3.22 & 3 & 1.07 & 775.33 & 0.000 \\
\hline & $\mathrm{pH}$ & 2.30 & 3 & 0.77 & 551.53 & 0.000 \\
\hline & Electrical conductivity & 2.95 & 3 & 0.98 & 171.03 & 0.000 \\
\hline \multirow[t]{9}{*}{ Error } & $\%$ Carbon & 56.43 & 24 & 2.35 & & \\
\hline & $\%$ Nitrogen & 0.238 & 24 & 0.01 & & \\
\hline & $\mathrm{CN}$ & 42.30 & 24 & 1.76 & & \\
\hline & $\mathrm{NH}_{4}-\mathrm{N}$ & 10.61 & 24 & 0.44 & & \\
\hline & $\mathrm{NO}_{3}-\mathrm{N}$ & 1587.16 & 24 & 66.13 & & \\
\hline & Mineral- N & 1723.04 & 24 & 71.79 & & \\
\hline & $\mathrm{NH}_{4}-\mathrm{N}: \mathrm{NO}_{3}-\mathrm{N}$ & 0.03 & 24 & 0.001 & & \\
\hline & $\mathrm{pH}$ & 0.033 & 24 & 0.001 & & \\
\hline & Electrical conductivity & 0.138 & 24 & 0.006 & & \\
\hline
\end{tabular}




\subsection{References}

Albanell, E., Plaixats, J., \& Cabrero, T. (1988). Chemical changes during vermicomposting (Eisenia fetida) of sheep manure mixed with cotton industrial wastes. Biology and Fertility of Soils, 6, 266-269.

Alexander, M. (1977). Mineralization of nitrogen In: M. Alexander (Ed.), Introduction to Soil Microbiology (2nd ed.). John Wilcy \& Sons New York.

Angers, D. A., \& Recous, S. (1997). Decomposition of wheat straw and rye residues as affected by particle size. Plant and Soil, 189, 197-203.

Atiyeh, R. M., Dominguez, J., Subler, S., \& Edwards, C. A. (2000). Changes in biochemical properties of cow manure during processing by earthworms (Eisenia andrei, Bouché) and the effects on seedling growth. Pedobiologia, 44, 709-724.

Avnimelech, Y., Bruner, M., Ezrony, I., Sela, R., \& Kochba, M. (1996). Stability indexes for municipal solid waste compost. Compost Science \& Utilization, 4, 13-20.

Baldock, J. A., Aoyama, M., \& Oades, J. M. (1994). Structural amelioration of a South Australian red-brown earth using calcium and organic amendments. Australian Journal of Soil Research, 32(3), 571-594.

Benitez, E., Sainz, H., Melgar, R., \& Nogales, R. (2002). Vermicomposting of a lignocellulosic waste from olive oil industry: A pilot scale study. Waste Management \& Research, 20, 134-134.

Benito, M., Masaguer, A., Moliner, A., Arrigo, N., \& Palma, R. M. (2003). Chemical and microbiological parameters for the characterisation of the stability and maturity of pruning waste compost. Biology and Fertility of Soils, 37, 184-189.

Bernal, M. P., Paredes, C., Sanchez-Monedero, M. A., \& Cegarra, J. (1998a). Maturity and stability parameters of composts prepared with a wide range of organic wastes. Bioresource Technology, 63, 91-99.

Bernal, M. P., Sanchez-Monedero, M. A., Paredes, C., \& Cegarra, J. (1998b). Maturity and stability parameters of composts prepared with a wide range of organic wastes. Bioresource Technology, 63, 91-99.

Bishop, P. L., \& Godfrey, C. (1983). Nitrogen transformations during sludge composting. BioCycle, 24, 34-39. 
Blaise, D., \& Bhaskar, K. S. (2003). Carbon mineralization patterns of cotton leaves and stems in vertisols and inceptisols. Archives of Agronomy and Soil Science, 49, 171-177.

Bremner, J. M., \& Keeney, D. R. (1965). Steam distillation methods for determination of ammonium, nitrate and nitrite. Analytica Chimica Acta, 32, 485-495.

Charest, M. H., Antoun, H., \& Beauchamp, C. J. (2004). Dynamics of water-soluble carbon substances and microbial populations during the composting of de-inking paper sludge. Bioresource Technology, 91, 53-67.

Chefetz, B., Hadar, Y., \& Chen, Y. (1998). Dissolved organic carbon fractions formed during composting of municipal solid waste: properties and significance. Acta Hydrochimica et Hydrobiologica, 26, 172-179.

Collins, H. P., Elliott, L. F., Rickman, R. W., Bezdicek, D. F., \& Papendick, R. I. (1990). Decomposition and interactions among wheat residue components. Soil Science Society of America Journal, 54, 780-785.

Conti, M. E., Arrigo, N. M., \& Marelli, H. J. (1997). Relationship of soil carbon light fraction, microbial activity, humic acid production and nitrogen fertilization in the decaying process of corn stubble. Biology and Fertility of Soils, 25, 75-78.

Cunha Queda, A. C. C., Vallini, G., Agnolucci, M., Coelho, C. A., Campos, L., \& de Sousa, R. B. (2002). Microbiological and Chemical Characterisation of Composts at Different Levels of Maturity, with Evaluation of Phytotoxicity and Enzymatic Activities. Microbiology of Composting, 345-345.

Ekinci, K., Keener, H. M., \& Elwell, D. L. (2000). Composting short paper fiber with broiler litter and additives. Part I: effects of initial $\mathrm{pH}$ and carbon/nitrogen ratio on ammonia emission. Compost Science \& Utilization, 8, 160-172.

Epstein, E. (1997). The Science of Composting. Technomic Publishing Co., Inc.: Lancaster, PA, USA.

Findenegg, G. R. (1987). A comparative study of ammonium toxicity at different constatn $\mathrm{pH}$ of the nutrient solution. Plant and Soil, 103, 239-243.

Garcia, C., Hernandez, T., \& Costa, F. (1991). Study on water extract of sewage sludge composts. Soil Science and Plant Nutrition, 37, 399-408. 
Garcia, C., Hernandez, T., Costa, F., \& Ayuso, M. (1992). Evaluation of the maturity of municipal waste compost using simple chemical parameters. Communications in Soil Science and Plant Analysis, 23, 1501-1512.

Gaur, A. C., \& Singh, G. (1995). Recycling of rural and urban wastes through conventional and vermicomposting. In: H. L. S. Tandon (Ed.), Recycling of Crop, Animal, Human and Industrial Waste in Agriculture (pp. 31-49). Fertilizer Development and Consultation Organization: New Delhi.

Golueke, C. G. (1977). Biological Reclamation of Solid Wastes. Rodale Press Inc.: Emmans, PA, USA.

Goyal, S., Dhull, S. K., \& Kapoor, K. K. (2005). Chemical and biological changes during composting of different organic wastes and assessment of compost maturity. Bioresource Technology, 96, 1584-1591.

Grigatti, M., Ciavatta, C., \& Gessa, C. (2004). Evolution of organic matter from sewage sludge and garden trimming during composting. Bioresource Technology, 91, 163-169.

Hand, P., Hayes, W. A., Frankland, J. C., \& Satchell, J. E. (1988). Vermicomposting of cow slurry. Pedobiologia, 31, 199-209.

Hartenstein, R., \& Hartenstein, F. (1981). Physicochemical changes effected in activated sludge by the earthworm Eisenia foetida. Journal of Environmental Quality, 10, 377-377.

He, X. T., Logan, T. J., \& Traina, S. J. (1995). Physical and chemical characteristics of selected U. S. municipal solid waste composts. Journal of Environmental Quality, 24, 543-552.

Huang, G. F., Fang, M., Wu, Q. T., Zhou, L. X., Liao, X. D., \& Wong, J. W. C. (2001). Co-composting of pig manure with leaves. Environmental Technology, 22, 1203-1212.

Iannotti, D. A., Grebus, M. E., Toth, B. L., Madden, L. V., \& Hoitink, A. J. (1994). Oxygen respirometry to assess stability and maturity of composted municipal solid waste. Journal of Environmental Quality, 23, 1177-1183.

Iglesias-Jiménez, E., \& Pérez-García, V. (1992). Determination of maturity indices for city refuse composts. Agriculture, Ecosystems \& Environment, 38, 331-343.

Iglesias Jimenez, E., Pérez García, V., \& Fernández Falcón, M. (1986). The agronomic value of the sewage sludge of Tenerife Composting. Agricultural Wastes, 17, 119-130. 
Inbar, Y., Hadar, Y., \& others. (1993). Recycling of cattle manure: the composting process and characterization of maturity. Journal of Environmental Quality, 22, 857-863.

Itavaara, M., Venelampi, O., Vikman, M., \& Kapanen, A. (2002). Compost maturityproblems associated with testing. Microbiology of Composting, 373-382.

Katayama, A., Hirai, M., Shoda, M., Kubota, H., \& Mori, S. (1985). Inhibitory factor of sewage sludge compost for growth of komatsuna Brassica campestris L. var. rapiferafroug. Environmental Pollution Series A, Ecological and Biological, 38, 45-62.

Lachnicht, S. L., Hendrix, P. F., Potter, R. L., Coleman, D. C., \& Crossley, D. A. (2004). Winter decomposition of transgenic cotton residue in conventional-till and no-till systems. Applied Soil Ecology, 27, 135-142.

Lasaridi, K., Protopapa, I., Kotsou, M., Pilidis, G., Manios, T., \& Kyriacou, A. (2006). Quality assessment of composts in the Greek market: The need for standards and quality assurance. Journal of Environmental Management, 80, 58-65.

Mathur, S. P., Owen, G., Dinel, H., \& Schnitzer, M. (1993). Determination of compost biomaturity. 1. Literature review. Biological Agriculture and Horticulture, 10, 65-85.

Miyittah, M., \& Inubushi, K. (2003). Decomposition and $\mathrm{CO}_{2}$-C Evolution of okara, sewage sludge, cow and poultry manure composts in soils Soil Science and Plant Nutrition, 49, 61-68.

Namkoong, W., Hwang, E. Y., Cheong, J. G., \& Choi, J. Y. (1999). A comparative evaluation of maturity parameters for food waste composting. Compost Science \& Utilization, 7, 55-62.

Ndegwa, P. M., \& Thompson, S. A. (2001). Integrating composting and vermicomposting in the treatment and bioconversion of biosolids. Bioresource Technology, 76, 107-112.

Negro, M. J., Solano, M. L., Ciria, P., \& Carrasco, J. (1999). Composting of sweet sorghum bagasse with other wastes. Bioresource Technology, 67, 89-92.

Olsen, S. R., Cole, C. V., Watanabe, F. S., \& Dean, L. A. (1954). Estimation of available phosphorus in soils by extraction with sodium bicarbonate. U.S. Department of Agriculture, Circular 939. 
Parè, T., Dinel, H., Schnitzer, M., \& Dumontet, S. (1998). Transformations of carbon and nitrogen during composting of animal manure and shredded paper. Biology and Fertility of Soils, 26, 173-178.

Pascual, J. A., Ayuso, M., Garcia, C., \& Hernandez, T. (1997). Characterization of urban wastes according to fertility and phytotoxicity parameters. Waste Management \& Research, 15, 103-103.

Poincelot, R. P. (1974). A scientific examination of the principles and practice of composting. Compost Science, 15, 24-31.

Ranalli, G., Bottura, G., Taddei, P., Garavani, M., Marchetti, R., \& Sorlini, C. (2001). Composting of solid and sludge residues from agricultural and food industries. Bioindicators of monitoring and compost maturity. Journal of Environmental Science and Health, Part A, 36, 415-436.

Roletto, E., Barberis, R., Consiglio, M., \& Jodice, R. (1985). Chemical parameters for evaluating compost maturity. BioCycle, 26, 46-47.

Saebo, A. A., \& Ferrini, F. (2006). The use of compost in urban green areas-A review for practical application. Urban Forestry \& Urban Greening, 4, 159-169.

SAS Institute. (2000). SAS Institute SAS/GRAPH software (Version 9.0). Cary, NC.: SAS Institute.

Saviozzi, A., Levi-Minzi, R., \& Riffaldi, R. (1988). Maturity evaluation of organic waste. BioCycle, 29, 54-56.

Saviozzi, A., Riffaldi, R., \& Levi-Minzi, R. (1987). Compost maturity by water extract analysis. In: M. De Bertoldi, M. P. Ferranti, P. L'Hermite \& F. Zucconi (Eds.), Compost: Production, Quality and Use (pp. 359-367). Elsevier Applied Science: London.

Senesi, N. (1989). Composted materials as organic fertilizers. The Science of the Total Environment, 81/82, 521-542.

Spohn, E. (1978). Determination of compost maturity. Compost Science, 19, 26-27.

Sullivan, D., \& Miller, R. (2001). Compost quality attributes, measurements and variability. In: P. Stofella \& B. A. Kahn (Eds.), Compost utilization in horticultural cropping systems (pp. 95-199). Lewis Publishers: Boca Raton, Florida. 
Thompson, W., Leege, P., Millner, P., \& Watson, M. E. (2003). Test methods for the examination of composts and composting. The US Composting Council, US Government Printing Office http://tmecc. org/tmecc/index. html.

Tognetti, C., Laos, F., Mazzarino, M. J., \& Hernandez, M. T. (2005). Composting versus vermicomposting: a comparison of end product quality. Compost Science \& Utilization, 13, 6-13.

Tognetti, C., Mazzarino, M. J., \& Laos, F. (2007). Improving the quality of municipal organic waste compost. Bioresource Technology, 98, 1067-1076.

Torbert, H. A., Prior, S. A., \& Rogers, H. H. (1995). Elevated atmospheric carbon dioxide effects on cotton plant residues decomposition. Soil Science Society of America Journal, 59, 1321-1328.

Veeken, A., Nierop, K., Wilde, V., \& Hamelers, B. (2000). Characterisation of NaOHextracted humic acids during composting of a biowaste. Bioresource Technology, 72, 3341.

Wang, P., Changa, C. M., Watson, M. E., Dick, W. A., Chen, Y., \& Hoitink, H. A. J. (2004). Maturity indices for composted dairy and pig manures. Soil Biology and Biochemistry, 36, 767-776.

Wu, L., Ma, L. Q., \& Martinez, G. A. (2000). Comparison of methods for evaluating stability and maturity of biosolids compost. Journal of Environmental Quality, 29, 424429.

Zhang, B. G., Li, G. T., Shen, T. S., Wang, J. K., \& Sun, Z. (2000). Changes in microbial biomass $\mathrm{C}, \mathrm{N}$, and $\mathrm{P}$ and enzyme activities in soil incubated with the earthworms Metaphire guillelmi or Eisenia fetida. Soil Biology and Biochemistry, 32, 2055-2062.

Zmora-Nahum, S., Markovitch, O., Tarchitzky, J., \& Chen, Y. (2005). Dissolved organic carbon (DOC) as a parameter of compost maturity. Soil Biology and Biochemistry, 37, 2109-2116.

Zucconi, F., \& De Bertoldi, M. (1987). Compost specifications for the production and characterization of compost from municipal solid waste. In: M. de Bertoldi, M. P. Ferranti, P. L'Hermite \& F. Zucconi (Eds.), Compost: Production, Quality and Use (pp. 30-50). Elsevier Applied Science: Essex.

Zucconi, F., Pera, A., Forte, M., \& De Bertoldi, M. (1981). Evaluating toxicity of immature compost. BioCycle, 22, 54-57. 


\section{Phytotoxicity of compost and vermicompost substrates}

\subsection{Introduction}

The principal requirement of compost or vermicompost to be safely applied for agricultural purposes is its degree of stability or maturity, which implies stable organic matter content and the absence of phytotoxic compounds and plant or animal pathogens (Bernal et al., 1998b). Maturity, generally refers to the degree of decomposition of phytotoxic organic substances and is associated with plant growth potential or phytotoxicity (Iannotti et al., 1993; Komilis \& Tziouvaras, 2009), whereas stability refers to the rate or degree of organic matter decomposition and often related with the microbial activity (Bernal et al., 1998b; Epstein, 1997).

Stability is evaluated by respirometric measurements (Adani et al., 2003; Iannotti et al., 1994; Lasaridi \& Stentiford, 1998) and/or by studying the transformations in the chemical characteristics of organic matter (Chefetz, 1998a, 1998b; Pichler \& KoegelKnabner, 2000; Sanchez-Monedero et al., 1999). On the other hand, maturity has been generally evaluated through plant or seed bioassays (Bernal et al., 1998a; Emino \& Warman, 2004; Zucconi et al., 1985). Stability and maturity usually go hand in hand, since phytotoxic compounds are released by the microorganisms during early stages of decomposition (Zucconi et al., 1985).

The bioassays of phytotoxicity have received great attention by environmental agencies of the world. Two bioassay techniques have been commonly used to evaluate compost phytotoxicity; plant growth bioassay and seed germination bioassay (Kapanen \& Itävaara 2001). Phytotoxicity is described as an adverse effect on living plants by substances present in the growth medium, when these substances are taken up and accumulated in plant tissue (Chang et al., 1992). The phototoxic effects of immature organic wastes are the result of the combination of several factors, rather than one (Zucconi et al., 1985).

A widely used maturity test is the germination index. This test is considered as a sensitive parameter to evaluate phytotoxicity (Tiquia et al., 1996; Zucconi et al., 1981); based on relatively simple to perform seed tests. The germination bioassays quantify seed growth through the application of compost extracts to the seeds (Komilis \& Tziouvaras, 2009). 
Such composts may contain various phytotoxic materials. Application of unstable or immature compost or vermicompost may inhibit seed germination, reduce plant growth and damage crops by competing for oxygen or causing phytotoxicity to plants due to insufficient biodegradation of organic matter (Brewer \& Sullivan, 2003; Cooperband et al., 2003; Wu et al., 2000).

Factors such as high heavy metals concentrations (Wollan et al., 1978), ammonia (Wong et al., 1983), ethylene oxide (Wong, 1985; Wong \& Chu, 1985), soluble salts (Adriano et al., 1973) and low-molecular weight fatty acids (acetic, propionic and n-butyric acid) (Chanyasak et al., 1983; Zucconi et al., 1985) have been shown to exert inhibitory effects and reduce seed germination and also inhibit root development (Kapanen \& Itävaara, 2001; Wu et al., 2000). The evaluation of organic wastes' toxicity by biological tests is therefore, important for screening the suitability of wastes for land application (Fuentes et al., 2004). For the materials used in this study, we hypothesized that electrical conductivity, $\mathrm{NH}_{3}$ and heavy metals within the FYM will be responsible for the retardation of the seed germination.

Seed germination and plant growth bioassays are the most common techniques used to evaluate waste phytotoxicity (Kapanen \& Itävaara, 2001). The germination index (GI) was introduced by Zucconi et al. (1985), and was calculated by the root length of cress (Lolium perene L.), and the germination percentage of selected seeds compared to a control (usually the deionized water). According to Zucconi et al. (1985), germination indices allow evaluation of both low levels of toxicity, which affect root growth, as well as of high levels of toxicity, which affect seed germination.

The effect of the phytotoxic factor depends on the composition of the feed stocks, the decomposition process and the concentration of the extract prepared. However, decomposed cotton residues are expected to have no adverse effects on seed germination but addition of farm yard manure may exert slight to moderate effects. There is an appreciable amount of work on phytotoxicity of a wide range of finished composts and vermicomposts. However, to my best knowledge, very few are extended to decomposed 
cotton residues. The composted and vermicomposted materials were chemically analysed in order to explain differences in phytotoxicity.

\section{2. $\underline{\text { Aim }}$}

This study aimed at evaluating the phytotoxicity and suitability of the composts and vermicomposts produced from cotton residues based on germination indexes of cress seeds.

\subsection{Materials and methods}

\subsubsection{Seed germination test:}

Seed germination test developed by Araújo and Monterio (2005) was used as a basic tool for studying phytotoxicity of the final compost and vermicompost. The tested materials were produced using cotton residues, farm yard manure (FYM) and soil, respectively. A ratio of 5:1 of cotton residues and soil was used for the vermicompost, while compost was prepared with a ratio of 5:1:1 of cotton residues, FYM, and soil respectively. The decomposition processes lasted for 20 weeks.

The chemical characteristics of the finished compost are: $\mathrm{pH}, 6.4 ; \mathrm{EC}, 2.96 \mathrm{dS} \mathrm{m}^{-1} ; \mathrm{N}$, 1.1\%; Fe, 13 mg kg ${ }^{-1}$; $\mathrm{Ca}, 81 \mathrm{mg} \mathrm{kg}{ }^{-1}$; K, $2.0 \mathrm{~g} \mathrm{~kg}^{-1}$; Na, $388.5 \mathrm{mg} \mathrm{kg}^{-1} ; \mathrm{NH}_{4}-\mathrm{N} 138.4 \mathrm{mg}$ $\mathrm{kg}^{-1}$. While the chemical characteristics of the final vermicompost are: $\mathrm{pH}, 7.9 ; \mathrm{EC}, 1.26$ dS m ${ }^{-1}$; N, 1.3\%; Fe, $26 \mathrm{mg} \mathrm{kg}^{-1}$; Ca, $336 \mathrm{mg} \mathrm{kg}^{-1} ; \mathrm{K}, 2.3 \mathrm{~g} \mathrm{~kg}^{-1} ; \mathrm{Na}, 539.2 \mathrm{mg} \mathrm{kg}^{-1}$; $\mathrm{NH}_{4^{-}}$ $\mathrm{N} 16.7 \mathrm{mg} \mathrm{kg}^{-1}$.

For the bioassay test, deionized water was added to the fresh samples of finished compost and vermicompost. The extracted solutions were prepared by shaking samples with distilled water for 15 min., using a horizontal shaker. After shaking, the suspension was centrifuged at $3000 \mathrm{rpm}$ for $20 \mathrm{~min}$., and filtered through a filter paper (Whatman No 42). Different concentrations were prepared as follow: $0 \mathrm{~g} \mathrm{~L}^{-1}$ (only water); $8 \mathrm{~g} \mathrm{~L}^{-1}(0.24 \mathrm{~g}$ of compost or vermicompost plus $30 \mathrm{ml}$ of water); $16 \mathrm{~g} \mathrm{~L}^{-1}(0.48 \mathrm{~g}$ of compost or vermicompost plus $30 \mathrm{ml}$ of water). The concentrations used were corresponded to the application of 796.7 and $1593.4 \mathrm{~g}$ of compost and 794.5 and $1589 \mathrm{~g}$ vermicompost per pot, these amounts corresponded to 4 and $8 \mathrm{~g}$ nitrogen of the compost and the vermicompost (121.3 and $242.6 \mathrm{~g} \mathrm{~N} \mathrm{~m}^{-2}$ ), respectively. 
For the germination test, 10 seeds of cress (Lepidium sativum L.) were placed on a Whatman filter paper (Number 42) in a series of $11 \mathrm{~cm}$ diameter Petri dishes with $10 \mathrm{ml}$ of the appropriate concentration of compost or vermicompost extract, while distilled water alone was applied to the control group. The Petri dishes were sealed with Parafilm (American National $\mathrm{Can}_{\mathrm{TM}}$ ) permeable to air and to minimize water loss. The seeds were kept in the dark at room temperature $\left(25^{\circ} \mathrm{C}\right)$ for three days. After the incubation period, the percentage of germinated seeds was recorded and the length of the primary root was measured.

The percentage of relative seed germination (RSG), relative root growth (RRG) and germination index (GI) were calculated according to Tam and Tiguia (1994) and Hoekstra et al. (2002) as follows:

$$
\begin{aligned}
& \text { RSG }(\%)=\frac{\text { Number of seeds germinated in extract }}{\text { Number of seeds germinated in control }} \times 100 \\
& \text { RRG }(\%)= \\
& \mathrm{GI}=\quad \frac{\text { Mean root length in exctract }}{\text { Mean root length in control }} \times 100 \\
& \frac{(\mathrm{RSG}) *(\mathrm{RRG})}{100}
\end{aligned}
$$




\subsection{Statistical analysis:}

Petri dishes were arranged in a completely randomized design (CRD) with three replications. The effects of the extracts on RSG, RRG and GI were analyzed by analysis of variance (ANOVA) using SAS System (SAS Institute, 2000) and Duncan's Multiple Range Test (DMRT) at $P<0.05$, was used to separate means.

\subsection{Results and discussion:}

For the vermicompost extracts, the relative root growth were greater than $90 \%$ for both concentrations (corresponded to $4 \mathrm{~g} \mathrm{~N}$ pot $^{-1}$ (VER8) and corresponded to $8 \mathrm{~g} \mathrm{~N}$ pot $^{-1}$ (VER16) (Fig. 5.1 A). The relative seed germination and germination index were greater than 80\% (Fig. 5.1 B \& C). Significant differences $(P<0.05)$ were found between both concentrations, in terms of relative root growth, where the extract concentration corresponded to $4 \mathrm{~g} \mathrm{~N}$ pot $^{-1}$ (VER8) gave greater values than that corresponded to $8 \mathrm{~g} \mathrm{~N}$ pot $^{-1}$ (VER16). The values of the germination index and relative seed germination recorded from the two concentrations were not significantly different $(P>0.05)$.

The values of relative seed growth, relative seed germination, and germination index were $>69 \%,>70 \%$, and $>50 \%$, respectively, in the extracts prepared from compost (Fig. 5.1 A, B \&C). Relative root growth was significantly lower $(P<0.05)$ in the extract concentration corresponded to $8 \mathrm{~g} \mathrm{~N}$ pot $^{-1}$ (CPF16) compared to that corresponded to $4 \mathrm{~g}$ $\mathrm{N}_{\text {pot }}{ }^{-1}$ (CPF8). Seeds germinated in both extracts revealed no significant differences in terms of relative seed germination and germination index $(P>0.05)$.

By analysis of variance (ANOVA), significant differences between means of the root growth and germination in the various extracts were observed, while the reverse was calculated for the relative seed germination (Table 5.1). Duncan's Multiple Range Test was further employed to separate a set of significantly different means between extracts prepared from compost and vermicompost.

At both concentrations (corresponded to 4 and $8 \mathrm{~g} \mathrm{~N} \mathrm{pot}^{-1}$ ), results indicated significant differences $(P<0.05)$ between extracts prepared from compost and vermicompost, in terms of relative root growth and germination index where values from vermicompost extracts were greater than those obtained from the compost ones. Regarding relative root 
growth, differences were found significant between all extracts, where the highest value was calculated for seeds grown on vermicompost extract corresponded to $4 \mathrm{~g} \mathrm{~N}$ pot $^{-1}$ (VER8) while the lowest was for seeds germinated on compost extract corresponded to 8 $\mathrm{g} \mathrm{N}^{-1}$ pot $^{-1}$ CPF16) (Fig. 5.1B).

The significant differences between values of relative seed growth were found between seeds germinated on extracts of compost, and vermicompost corresponded to $4 \mathrm{~g} \mathrm{~N}$ pot $^{-1}$ (VER8 and CPF8). No significant differences $(P>0.05)$ were calculated between germination index values of both extracts of vermicompost; the same was for extracts of compost (Fig. 5. 1A), but significant differences $(P<0.05)$ were found between germination index values of seeds grown on vermicompost and compost extracts, where higher values were found in the former (Fig. 5. 1C).

Root growth of the germinated seeds was remarkably able to differentiate between the extracts of compost and vermicompost. This point is in consistent with results found by Wong et al. (1981), who proposed that root growth as a better parameter in toxicity analyses. Similar findings were found by Hoekstra et al. (2002); who reported that the ANOVA revealed no significant effect of dung type or concentration on relative seed germination; therefore, they determined germination index only by the relative root growth.

In all studied germination indexes and at both concentrations, seeds grown in compost extract; had lower values than those grown on vermicompost extracts; this could be attributed to the presence of the phytotoxic substances due to the addition of farm yard manure during experiment initiation. Ammonia $\left(\mathrm{NH}_{3}\right)$ is a common by-product of animal waste (Ko et al., 2008); therefore, the added farm yard manure to the compost feedstocks is considered to contain an appreciable amount of ammonia. A concentration of $\mathrm{NH}_{3}$ in water extracts of $13 \mathrm{mM}$ has been reported to be toxic to plant (Bennett \& Adams, 1970; Hoekstra et al., 2002). 

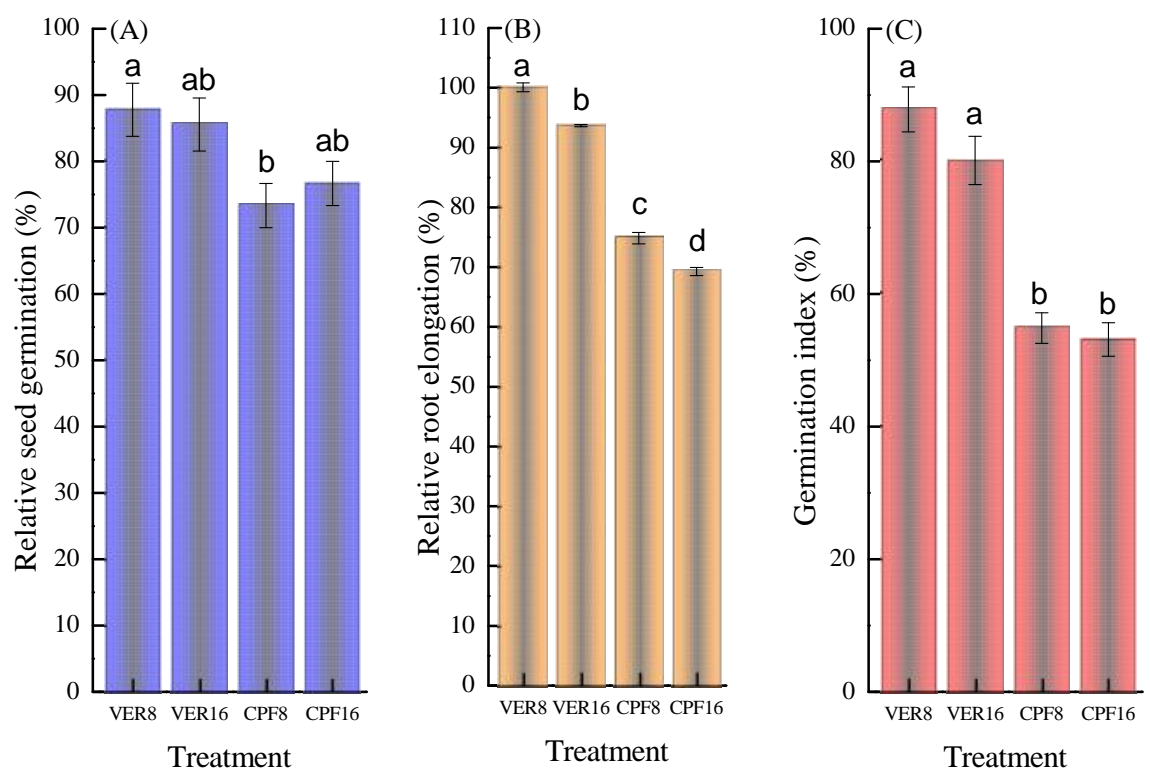

Fig.5.1. Relative seed germination (RSG) (A), relative root growth (RRG) (B) and germination index (GI) (C) of cress (Lepidium sativum L.) for different concentrations of compost and vermicompost; VER8 and CPF8: concentration corresponding to $8 \mathrm{~g} \mathrm{~L}^{-1}$ of compost and vermicompost, respectively; VER16 and CPF16 concentration corresponding to $8 \mathrm{~g} \mathrm{~L}^{-1}$ of compost and vermicompost respectively. Means and standard errors of three replicates are shown. 
Generally, phytotoxicity or poor seed response can result from several factors; the most important are the accumulation of alcohols, phenolic compounds, low-molecular weight organic acids, ammonia and toxic nitrogen compounds, and the presence of heavy metals and mineral salts (Kapanen \& Itävaara, 2001; Tam \& Tiquia, 1994). Most of these factors influence seed germination simultaneously, and it is very difficult to assess which parameter determines the greatest influence.

Among the factors responsible for the retardation or the delay of the seed germination, we only measured the electrical conductivity and $\mathrm{NH}_{4}-\mathrm{N}$ in the final products. Ammonium-N in solution can be toxic to plant growth (Mengel \& Kirkby, 1982); however, the measured $\mathrm{NH}_{4}-\mathrm{N}$ concentrations in the final products are below the reported critical phytotoxic levels $\left(<400 \mathrm{mg} \mathrm{kg}^{-1}\right)$. This result agrees well with the conclusion reported by Hoekstra et al, (2002) that ammonium appeared not to be inversely affecting root growth of the germinated seeds. Therefore, we looked for the toxicity of the presence of $\mathrm{NH}_{3}$, which affects plant growth and metabolism at low concentration levels at which $\mathrm{NH}_{4}-\mathrm{N}$ is not harmful (Mengel \& Kirkby, 1982). The concentration of $\mathrm{NH}_{3}$ depends on the concentration of $\mathrm{NH}_{4}-\mathrm{N}$ via the equilibrium:

$$
\mathrm{NH}_{4}{ }^{+}(\mathrm{aq}) \rightleftharpoons \mathrm{NH}_{3}{ }^{+}(\mathrm{aq})+\mathrm{H}^{+} \ldots \ldots(4.4)
$$

and on the volatilization of $\mathrm{NH}_{3}$ (Bennett \& Adams, 1970). A concentration of $\mathrm{NH}_{3}$ of 13 $\mathrm{mM}$ has been proven to be toxic (Bennett \& Adams, 1970; Hoekstra et al., 2002). However, concentrations of $\mathrm{NH}_{3}$ (as calculated from the $\mathrm{pH}$ and $\mathrm{NH}_{4}-\mathrm{N}$ concentration by means of equilibrium equation (4.4)) in the finished compost were $0.01 \mathrm{mM}$ and $0.4 \mathrm{mM}$ for the vermicompost; both values are below the threshold value.

The electrical conductivity measured in extracts of the finished compost and vermicompost were 1.26 and $2.96 \mathrm{dS} \mathrm{m}^{-1}$, respectively; however, the value of the vermicompost is below the value considered not to be harmful for seed germination (2.0 $\mathrm{dS} \mathrm{m}^{-1}$ ) (Hoekstra et al., 2002), while EC of the compost is above that value. Therefore, the phytotoxicity in this study is thought to be salt-affected.

Iannotti et al. (1994a) reported that for cress bioassays, the 10 -fold diluted extracts yielded a germination index of only $60 \%$, while the undiluted extract was inhibitory at all 
maturity levels (EC $>10 \mathrm{dS} \mathrm{m}^{-1}$ throughout the experiment period). The same authors concluded that organic acids produced as a result of decomposition as well as $\mathrm{N}$ deficiency in immature compost and salinity were probably the key factors affecting germination of cress seed. The effect of salinity was also reported by Marchiol et al. (1999); who their study revealed that the higher the EC of the leachates, the lower the germination indexes and the higher the average times of germination for all 23 seeds used throughout the study.

Zucconi et al. (1981) reported that compost with germination greater than $80 \%$ was phytotoxin-free, and considered as having a completed maturity. Similar suggestions were reported by Tiquia et al. (1996); Fang and Wong (1999). From our results, germination indexes of vermicompost were 80.2 and $87.8 \%$ for extract corresponded to 8 $\mathrm{g} \mathrm{N}_{\text {pot }}{ }^{-1}$ (VER16), and the extract corresponded to $4 \mathrm{~g} \mathrm{~N}$ pot $^{-1}$ (VER8), respectively. Both compost extracts exert inhibitory effects on cress seeds, consequently; the germination indexes were 54.9 and $53.1 \%$ for extracts corresponded to $4 \mathrm{~g} \mathrm{~N}_{\text {pot }}{ }^{-1}$ (CPF8), and the extract corresponded to $8 \mathrm{~g} \mathrm{~N} \mathrm{pot}^{-1}$ (CPF16), restively. However, both values are below the reported value.

Although lower value (> 70\%) has been suggested by Fuentes et al. (2004) and Antil and Raj (2011) for the disappearance of phytotoxic substances of extracts prepared from sewage sludge and from farm and agro-industrial composts; however, germination indexes of the compost extracts of this work did not even attain this value. As per the germination index reported limit, vermicompost considered mature and could safely be used for soil applications and plant growth while compost showed inhibitory effects. 
Table 5.1: Analysis of Variance (ANOVA) of the effects of extracts prepared from compost and vermicompost on the germination indexes of cress (Lepidium sativum $\mathrm{L}$.) seeds

\begin{tabular}{l|l|l|l|l|l|l|}
\multicolumn{2}{l|}{} & $\begin{array}{l}\text { Sum of } \\
\text { Squares }\end{array}$ & df & $\begin{array}{l}\text { Mean } \\
\text { Square }\end{array}$ & F & Sig. \\
\hline RRE & Between Groups & 1954.1 & 3 & 651.4 & 450.4 & $<0.0001$ \\
& Within Groups & 11.6 & 8 & 1.5 & & \\
\hline RSG & Between Groups & 432.3 & 3 & 144.10 & 3.5 & 0.067 \\
\hline GI & Within Groups & 325.9 & 8 & 40.7 & & \\
& Between Groups & & 3 & 931.1 & 34.2 & $<0.0001$ \\
& Within Groups & & 8 & 27.2 & & \\
\hline
\end{tabular}

Between groups: extracts prepared from compost and vermicompost corresponding to $4 \mathrm{~g} \mathrm{~N} \mathrm{pot}^{-1}$ (VER8 \& CPF8) and $8 \mathrm{~g} \mathrm{~N}^{-1}{ }^{-1}$ (VER16 \& CPF16); Within the group:: error. RRE: relative root elongation; RSG: relative seed germination; GI: germination index. 


\subsection{Conclusions}

From the results of this work, it may be concluded that, vermicompost and compost vary considerably in phytotoxicity. Vermicompost performed best in cress bioassay and could be considered mature while compost did show adverse effects on seed germination and may need more processing time. Germination indexes obtained for vermicompost are greater than the values advised for the finished compost while compost did not attain it. The retarded seed germination observed in the compost extracts could partially be due to the high content of soluble salts and/or $\mathrm{NH}_{3}$ concentration. The $\mathrm{NH}_{3}$ concentration is below the advised toxicity level while the EC was above the threshold; therefore, the phytotoxicity is thought to be salt-related. Consequently, vermicompost can safely be applied for plant growth, and more processing time is needed for the compost. 


\subsection{References}

Adani, F., Gigliotti, G., Valentini, F., \& Laraia, R. (2003). Respiration index determination: a comparative study of different methods. Compost Science \& Utilization, $11,144-151$.

Adriano, D. C., Pratt, A. C., \& Sharpless, P. F. (1973). Effect of soil application of dairy manure on germination and emergence of some selected Crops. Journal of Environmental Quality, 2, 396-396.

Antil, R. S., \& Raj, D. (2011). Evaluation of maturity and stability parameters of composts prepared from agro-industrial wastes. Bioresource Technology, 102, 28682873.

Araújo, A. S. F., \& Monteiro, R. T. R. (2005). Plant bioassays to assess toxicity of textile sludge compost. Scientia agricola, 62, 286-286.

Baldock, J. A., Aoyama, M., \& Oades, J. M. (1994). Structural amelioration of a South Australian red-brown earth using calcium and organic amendments. Australian Journal of Soil Research, 32(3), 571-594.

Bennett, A. C., \& Adams, F. (1970). Concentration of $\mathrm{NH}_{3}$ (aq) required for incipient $\mathrm{NH}_{3}$ toxicity to seedlings. Soil Science Society of America Proceedings.34, 259-263.

Bernal, M. P., Paredes, C., Sanchez-Monedero, M. A., \& Cegarra, J. (1998a). Maturity and stability parameters of composts prepared with a wide range of organic wastes. Bioresource Technology, 63, 91-99.

Bernal, M. P., Sanchez-Monedero, M. A., Paredes, C., \& Cegarra, J. (1998b). Maturity and stability parameters of composts prepared with a wide range of organic wastes. Bioresource Technology, 63, 91-99.

Brewer, L. J., \& Sullivan, D. M. (2003). Maturity and stability evaluation of composted yard trimmings. Compost Science and Utilization, 11, 96-112.

Chang, A. C., Granato, T. C., \& Page, A. L. (1992). A methodology for establishing phytotoxicity criteria for chromium, copper, nickel, and zinc in agricultural land application of municipal sewage sludges. Journal of Environmental Quality, 21, 521-536.

Chanyasak, V., Katayama, A., Fukui, H., \& others. (1983). Effects of compost maturity on growth of komatsuna (Brassica Rapa var. pervidis) in Neubauer's pot: I. Comparison of growth in compost treatments with that in inorganic nutrient treatments as controls. Soil Science and Plant Nutrition, 29, 239-250.

Chefetz, B. (1998a). Characterization of dissolved organic matter extracted from composted municipal solid waste. Soil Science Society of America Journal, 62, 326-332. 
Chefetz, B. (1998b). Dissolved organic carbon fractions formed during composting of municipal solid waste: Properties and significance. Acta Hydrochimica et Hydrobiologica, 26, 172-179.

Cooperband, L. R., Stone, A. G., Fryda, M. R., \& Ravet, J. L. (2003). Relating compost measures of stability and maturity to plant growth. Compost Science \& Utilization, 11, 113-124.

Emino, E. R., \& Warman, P. R. (2004). Biological assay for compost quality. Compost Science \& Utilization, 12, 342-348.

Epstein, E. (1997). The Science of Composting. Technomic Publishing Co., Inc.: Lancaster, PA, USA.

Fang, M., \& Wong, J. W. C. (1999). Effects of lime amendment on availability of heavy metals and maturation in sewage sludge composting. Environmental Pollution, 106, 8389.

Fuentes, A., Lloréns, M., Saez, J., Aguilar, M. I., Ortuno, J. F., \& Meseguer, V. F. (2004). Phytotoxicity and heavy metals speciation of stabilised sewage sludges. Journal of Hazardous Materials, 108, 161-169.

Hoekstra, N. J., Bosker, T., \& Lantinga, E. A. (2002). Effects of cattle dung from farms with different feeding strategies on germination and initial root growth of cress (Lepidium sativum L.). Agriculture, Ecosystems \& Environment, 93, 189-196.

Iannotti, D. A., Grebus, M. E., Toth, B. L., Madden, L. V., \& Hoitink, A. J. (1994). Oxygen respirometry to assess stability and maturity of composted municipal solid waste. Journal of Environmental Quality, 23, 1177-1183.

Iannotti, D. A., Pang, T., Totth, B. L., Elwell, D. L., Keener, H. M., \& Hoitink, H. A. J. (1993). A quantitative respirometric method for monitoring compost stability. Compost Science \& Utilization, 1, 52-65.

Kapanen, A., \& Itävaara, M. (2001). Ecotoxicity tests for compost applications. Ecotoxicology and Environmental Safety, 49, 1-16.

Ko, H. J., Kim, K. Y., Kim, H. T., Kim, C. N., \& Umeda, M. (2008). Evaluation of maturity parameters and heavy metal contents in composts made from animal manure. Waste Management, 28, 813-820.

Komilis, D. P., \& Tziouvaras, I. S. (2009). A statistical analysis to assess the maturity and stability of six composts. Waste Management, 29, 1504-1513.

Lasaridi, K. E., \& Stentiford, E. I. (1998). A simple respirometric technique for assessing compost stability. Water Research, 32, 3717-3723. 
Marchiol, L., Mondini, C., Leita, L., \& Zerbi, G. (1999). Effects of municipal waste leachate on seed germination in soil-compost mixtures. Restoration Ecology, 7, 155-161.

Mengel, K., \& Kirkby, E. A. (1982). Principles of Plant Nutrition (3rd ed.). International potash Institute, Bern, Switzerland. pp 353.

Pichler, M., \& Koegel-Knabner, I. (2000). Chemolytic analysis of organic matter during aerobic and anaerobic treatment of municipal solid waste. Journal of Environmental Quality, 29, 1337-1344.

Sanchez-Monedero, M. A., Roig, A., Cegarra, J., \& Bernal, M. P. (1999). Relationships between water-soluble carbohydrate and phenol fractions and the humification indices of different organic wastes during composting. Bioresource Technology, 70, 193-201.

Tam, N. F. Y., \& Tiquia, S. (1994). Assessing toxicity of spent pig litter using a seed germination technique. Resources, Conservation and Recycling, 11, 261-274.

Tiquia, S. M., Tam, N. F. Y., \& Hodgkiss, I. J. (1996). Effects of composting on phytotoxicity of spent pig-manure sawdust litter. Environmental Pollution, 93, 249-256.

Wollan, E., Davis, R. D., \& Jenner, S. (1978). Effects of sewage sludge on seed germination. Environmental Pollution, 17, 195-205.

Wong, M. H. (1985). Phytotoxicity of refuse compost during the process of maturation. Environmental Pollution Series A, Ecological and Biological, 37, 159-174.

Wong, M. H., Cheung, Y. H., \& Cheung, C. L. (1983). The effects of ammonia and ethylene oxide in animal manure and sewage sludge on the seed germination and root elongation of Brassica parachinensis. Environmental Pollution Series A, Ecological and Biological, 30, 109-123.

Wong, M. H., \& Chu, L. M. (1985). The responses of edible crops treated with extracts of refuse compost of different ages. Agricultural Wastes, 14, 63-74.

Wong, M. H., Lau, W. M., \& Yip, S. W. (1981). Effects of sludge extracts on seed germination and root elongation of crops. Environmental Pollution Series A, 25, 87-98.

Wu, L., Ma, L. Q., \& Martinez, G. A. (2000). Comparison of methods for evaluating stability and maturity of biosolids compost. Journal of Environmental Quality, 29, 424429.

Zucconi, F., Monaco, A., Forte, M., \& De Bertoldi, M. (1985). Phytotoxins during the stabilization of organic matter.

Zucconi, F., Pera, A., Forte, M., \& De Bertoldi, M. (1981). Evaluating toxicity of immature compost. BioCycle, 22, 54-57. 


\section{Effect of composted and vermicomposted cotton residue on ryegrass (Lolium perene $\mathrm{L}$. .) growth}

\subsection{Introduction}

Addition of organic residues to cultivated lands or as potting material has been extensively studied because it helps recycling nutrients and reducing fertilizer costs in crop production systems and may generate residual effects that should be taken into account when planning the next crop (Eghball et al., 2004). The tremendous amount of organic matter and mineral components that are contained in biowastes (municipal solid waste, sewage sludge, manures, etc.) allows its application for crop production and soil reclamation, after a proper stabilization process (Veeken et al., 2000). Crop residues are also considered vital resources for the conservation of soil productivity; not only because of their known effects on soil physical properties (Hulugalle et al., 1986); but also due their immediate and residual effects on nutrients to the crop (Hadas et al., 2004).

The chemical composition of the organic materials is the most essential criterion in its recycling, marketing and utilization in agriculture (Lasaridi et al., 2006). The decomposition process also plays an important role its utilization, therefore, organic amendments prepared with different methods (composting or vermicomposting) with different processing periods, produce final products with different quality properties (Gaur \& Singh, 1995; Ranalli et al., 2001).

Decomposition normally undergone changes in the initial chemical compositions of the organic materials, therefore, finished composts differ in their effects on nutrient availability and plant growth compared to the feedstocks. Maturity of soil incorporated residues (Jan-Hammermeister et al., 1994a; Voroney et al., 1989), the amount of residue $\mathrm{N}$ in labile, readily metabolizable form (Jan-Hammermeister et al., 1994b; Jensen, 1996) or simply the content of water-soluble substances in residues (Jensen, 1996) have been shown to contribute to the release pattern of residue derived inorganic N. It is commonly reported that composted organic residues release lower plant-available $\mathrm{N}$ than noncomposted ones due to higher organic matter stabilization and $\mathrm{N}$ losses during decomposition (Eghball et al., 1997; Kithome et al., 1999; Zucconi \& De Bertoldi, 1987). 
The mineralization of organic nitrogen $(\mathrm{N})$ is one of major important and prerequisite of its supply to plants (Appel \& Mengel, 1993). This especially important in the arid and semi-arid regions of the developing countries where inorganic fertilizers are hardly to be afforded by small farmers and considerable amounts of crop residues and straws are available, therefore, considerable efforts have been made and should continue to develop alternatives or complementary cost-effective practices to $\mathrm{N}$ fertilization.

The rate of $\mathrm{N}$ mineralization from organic materials is controlled by the decomposer organisms, the environmental conditions (temperature, moisture etc.) and the chemical composition of the material itself (Heal et al., 1997; Swift et al., 1979). In order to better predict $\mathrm{N}$ release from the organic fraction of the organic residues, we need to improve our understanding of the three controlling factors.

The chemical composition is one of the most important factors governing the turnover and fate of crop residues. Therefore, large differences in decomposition rate and nutrient release have been variously ascribed to differences in chemical characteristics (Janzen \& Kucey, 1988). The chemical composition of the organic residues is extremely variable; some forms of the organic $\mathrm{N}$, like proteins and amino acids are readily mineralized to inorganic forms, while others are chemically or structurally protected in plant tissues, for example in lignin, a recalcitrant source of $\mathrm{N}$ (Chadwick et al., 2000).

Plant materials are basically composed of similar components, but differ in their proportions (Hadas et al., 2004). The kinetics of decomposition or $\mathrm{N}$ release from crop residues has been related to the residue $\mathrm{N}$ content or its $\mathrm{C}: \mathrm{N}$ ratio, but the presence and amount of polyphenolics concentration and lignin or recalcitrant carbon may reduce the rate of N mineralization (Palm \& Sanchez, 1991; Quemada \& Cabrera, 1995; Vigil \& Kissel, 1991).

Crop residues poor in $\mathrm{N}$ have limited use in the short term (Constantinides \& Fownes, 1994) since low $\mathrm{N}$ content limits the growth of microorganisms involved in decomposition. There is general consensus that net $\mathrm{N}$ mineralization occurs if the $\mathrm{N}$ concentration is above $2 \%\left(20 \mathrm{~g} \mathrm{~kg}^{-1}\right)$ and immobilization occurs below that concentration (Palm \& Sanchez, 1991). Harmsen and Van Schreven (1955) concluded 
that $\mathrm{N}$ concentration of $15-20 \mathrm{~g} \mathrm{~kg}^{-1}$ (C:N ratios of 20-25) will consistently give a net $\mathrm{N}$ mineralization, whereas, at lower $\mathrm{N}$ concentrations net immobilization is expected.

The C:N ratio of the organic residues as the most often used as an index of assess whether the residues will release or immobilize $\mathrm{N}$ (Hadas et al., 2004). Alexander (1977b) stated that the critical $\mathrm{C}: \mathrm{N}$ ratio of a crop residue for net $\mathrm{N}$ mineralization to occur is less than 15 to 20, whereas $\mathrm{C}: \mathrm{N}$ ratios wider than 30 favor net immobilization. On the other hand, a wider range even was suggested by Vigil and Kissel (1991) who integrated $\mathrm{N}$ immobilization data from several medium to long-term experiments with residues having a wide range $\mathrm{C}: \mathrm{N}$ ratios, and showed that the break-even point between net immobilization and mineralization of residue was at $\mathrm{C}: \mathrm{N}$ ratio of 41 .

Mature composts still contain small amounts of easily transformable $\mathrm{C}$ compounds; their $\mathrm{C}: \mathrm{N}$ ratio is normally 11-15, and thus only slightly above that of the soil (ca. 10). With transformations on a low level, $\mathrm{N}$ immobilization and mineralization are almost in balance and its mineral $\mathrm{N}$ can thus be considered as almost completely plant available in the year of application (Ebertseder \& Gutser, 2001).

Another factor controlling $\mathrm{N}$ mineralization patterns is polyphenols; polyphenolic as reactive compounds that can form stable polymers with many forms of nitrogen (amino groups and basic $\mathrm{N}$-containing groups) may affect $\mathrm{N}$ release patterns by making the material resistant to decomposition (Martin \& Haider, 1980; Palm \& Sanchez, 1991).

The stable polymers formed between phenolics and $\mathrm{N}$-containing compounds have characteristics similar to fulvic and humic acids found in the soil (Martin \& Haider, 1980). Sivapalan et al. (1985) found lower net $\mathrm{N}$ mineralization from tea leaves that had high soluble $\mathrm{N}$ and high polyphenolic content in comparison with high soluble $\mathrm{N}$ content but low polyphenolics, suggesting that the polyphenolics made the soluble $\mathrm{N}$ unavailable.

One of the effective factors that bind organic $\mathrm{N}$ making it unavailable is lignin, therefore the percentage of lignin or lignin: $\mathrm{N}$ ratio is often an effective ratio for the $\mathrm{N}$ release pattern and Muller et al. (1988) found it much better predictor of plant residue decomposition rate than $\mathrm{N}$ concentration. Data in all various studies indicated that lignin concentration might influence the percent $\mathrm{N}$ mineralization from a given residue, even 
when the $\mathrm{N}$ concentration in the tissue was relatively high (Frankenberger \& Abdelmagid, 1985; Palm \& Sanchez, 1991). Studies with no lignin effect on $N$ mineralization rate were generally conducted with plant materials containing low lignin concentrations (Fox et al., 1990).

When the plant residues contains high concentration of lignin or polyphenols, there may be little $\mathrm{N}$ mineralization in spite of $\mathrm{N}$ concentrations considerably greater than the critical level (15-25 $\mathrm{g} \mathrm{kg}^{-1}$ ) (Melillo et al., 1982). Haynes (1986) believed that lignins and polyphenols reduce $\mathrm{N}$ mineralization rate because lignins degrade to phenolic compounds and these compounds as well as the polyphenols already present combine with plant proteins and amino acids to form polymers that resist decay.

Short-term and long-term net $\mathrm{N}$ mineralization is correlated with different residue properties. Therefore, Griller and Cadisch (1997) concluded that no single index can characterize the quality of the crop residues. Moreover, a wide range of materials tested resulted in different conclusions as the suitability of certain properties to predict rates of decomposition of residues and their effect on available $\mathrm{N}$ in soil. However, measurement of $\mathrm{N}$ mineralization and immobilization rates will enable mathematical models of nutrient release and leaching to be developed, which in turn can be used to provide management guidelines for waste application on land (Zaman et al., 1998).

An important question pertinent to the efficient use of cop residues is whether their rates of nutrient release can be effectively managed to coincide with crop demand (Tilman et al., 2002). Therefore, detailed knowledge about the coupling between crop residue quality and subsequent nutrient fluxes during decomposition may improve the ability to predict the availability of nutrients for crops.

The value of the organic residue as a source of $\mathrm{N}$ depends on the degree of the synchronization between the $\mathrm{N}$ release and $\mathrm{N}$ uptake by the succeeding crop (Wivstad, 1999). If rates of $\mathrm{N}$ release exceed plant demand the $\mathrm{N}$ becomes susceptible to various pathways of loss (Goudling, 2004; Peoples et al., 2004a). In some instances, organic amendments can cause excess accumulation of $\mathrm{NO}_{3}-\mathrm{N}$ in soil (Khalil et al., 2005) with 
potentially detrimental effects on the environment. Conversely, if rates of $\mathrm{N}$ release are too slow, then crop yields may be constrained.

The best way to synchronize soil $\mathrm{N}$ availability to crop demand is by managing the quantity, quality, timing and placement of organic residues added to the soil (Mafongoya et al., 1998; Palm, 1995). Traditional methods in determining source nutrient availability involve measuring plant uptake, a function of the availability of soil nutrients and plant growth rate, and nitrogen mineralization incubation tests, to find the best synchronize plant uptake with availability of $\mathrm{N}$ from organic residues. While very fast $\mathrm{N}$ mineralization rates can be responsible for considerable $\mathrm{N}$ losses through leaching, denitrification or volatilization, when $\mathrm{N}$ mineralization is very low little $\mathrm{N}$ availability can lead to limitations in crop growth (Myers et al., 1994).

Nutrient content in harvested materials provides an estimate of nutrient supply from a given source (Havilah et al., 1996). Such an evaluation is more reliable when more than one harvest is considered (Nooman \& Fuleky, 1995).

A wide range of results has been obtained in relation to the efficiency of compost and vermicompost as sources of $\mathrm{N}$ for plants, as the $\mathrm{N}$ availability is closely related to the degree of maturity (Gallardo-Lara \& Nogales, 1987).

The application of different organic residues has different effects on plant biomass yield, nutrients contents, and soil nutritive values. Iglesias-Jimenez and Alvarez (1993) found in a ryegrass pot experiment that the highly mature composted municipal refuse increased dry matter yield, soil mineral $\mathrm{N}$, and plant $\mathrm{N}$ uptake proportional to the applied rate.

The positive effects of organic residues on plant growth was also revealed by Schmeisky et al. (2003), who concluded that the increase in the plant biomass with the application of biocompost was due to the improvement in soil mineral contents ( $\mathrm{N}, \mathrm{Ca}, \mathrm{Mg}, \mathrm{K}$ and $\mathrm{P}$ ).

Three to seventy five percent of $\mathrm{N}$ in the organic material applied as biosolids was recovered in plant biomass where the efficiency of the organic material as $\mathrm{N}$ source depends on soil type (Corrêa, 2004). The $\mathrm{N}$ content in plant tissues obtained by organic fertilization was greater than in the mineral fertilizer treatments (Cegarra et al., 1996). Smith and Tibbett (2004) from their field study with a single application of three sludge 
types, reported that amended soils showed significant effects on plant growth compared to the non-amended soil (control), where the $\mathrm{N}$ concentration in the ryegrass and biomass yield were proportionally increased with the application rate.

The improvement in soil properties with organic manures was also studied by Cheng et al. (2007) who concluded that, soil amended with 5-20\% (substrate: base soil) of composted sewage sludge greatly improved the contents of $\mathrm{N}, \mathrm{P}, \mathrm{K}$ and chlorophyll of perennial ryegrass, and the clippings were higher in the amended soils compared to the control.

In a 3-year field experiment with five diverse non-agricultural organic wastes (distillery pot ale, dairy salt whey, abattoir blood and gut contents, composted green waste, and paper mill) and mineral fertilizer, Douglas et al. (2003) attributed the differences in the scale of the grass yield between treatments to the differences in $\mathrm{N}$ supply.

On the other hand, Coutinho et al. (1997) concluded that ryegrass dry matter yield, N content, and $\mathrm{N}$ uptake did not increase in composted sewage sludge treated soils, and $\mathrm{P}$ content of the plant increased at the second harvest, but the effect was negligible in the subsequent harvest. and the authors attributed that to the chemical rather that the biological reactions which led to the redistribution of the $\mathrm{P}$ in the organic sewage sludge composted with saw dust to more firmly held forms after its application to the soil.

Concerning nitrogen mineralization incubation; several workers have tested the release of $\mathrm{N}$ from organic wastes mineralization to ryegrass, maize and wheat (Evers, 2002; Vagstad et al., 2001; Vasconcelos et al., 1999); for instance; Cordovil et al., (2007), reported that in aerobic incubations of organic wastes, experimental data obtained in the pot trials was consistent with the trend of the nitrogen net mineralization. Values of potentially mineralizable nitrogen from the equations obtained by model fitting, to the incubation data, were well correlated to ryegrass $\mathrm{N}$ uptake.

The effect of the incubation period has been demonstrated to have positive effects on the amount of mineral N. For example, Coutinho et al. (1997) reported that time had a highly significant effect on the $\mathrm{NH}_{4}{ }^{+}$and $\mathrm{NO}_{3}{ }^{-}$contents; reflecting the favorable conditions in temperature and moisture for microbial activity during the incubation. The same authors 
concluded that the $\mathrm{N}$ mineralized from the organic wastes was inadequate for the normal growth rate of ryegrass. Nevertheless, the biomass yield and $\mathrm{N}$ nutrition agrees with the results of the incubation experiment.

The availability of $\mathrm{N}$ to plants from organic wastes has been investigated by Smith et al. (2001a; 2001b), who developed and tested methods to estimate potential mineralizable nitrogen. Studies carried out by Smith et al. (2001a) showed that there were significant positive correlations between ryegrass $\mathrm{N}$ uptake from organic wastes and potential mineralizable nitrogen estimated. Although several of these biological experiments have led to promising results, there is still no accurate knowledge on the ability of organic wastes to release $\mathrm{N}$ for crop nutrition (Cordovil et al., 2007). The amount of $\mathrm{C}$ and $\mathrm{N}$ in residues in decomposing microbial biomass are important factors controlling the occurrence of net $\mathrm{N}$ mineralization or net $\mathrm{N}$ immobilization and because $\mathrm{C}: \mathrm{N}$ ratio of the residue cannot explain all the variability observed in $\mathrm{N}$ mineralization among residues (Cabrera et al., 2005), considerable efforts has been dedicated to the identification of specific compounds that play critical roles in $\mathrm{N}$ mineralization such as polyphenols, proteins, soluble carbohydrates, and hemicellulose-like, cellulose-like, and lignin-like compounds (Palm \& Sanchez, 1991; Rowell et al., 2001; Vigil \& Kissel, 1991). However, research in this area should continue to identify specific $\mathrm{N}$ compounds or group of $\mathrm{N}$ compounds that affect $\mathrm{N}$ mineralization in different types in organic residues (Cabrera et al., 2005). Other properties of some organic residues, such as $\mathrm{pH}$, salinity and heavy metal concentration, may also affect microbial activity and $\mathrm{N}$ mineralization. For instance, the addition of heavy metals to sewage sludge in some cases has increased $\mathrm{N}$ mineralization (Hassen et al., 1998; Khan \& Scullion, 2002) and in some other studies has decreased N mineralization (Dar \& Mishra, 1994). Additional research is needed to understand the mechanical involved and this work should include evaluation of the microbial population and microfauna involved in the decomposition process (Cabrera et al., 2005).

From the above literature, it is evident that the best predictor of net $\mathrm{N}$ mineralization will vary with the experimental method used and the method of the measuring the net effect (i.e., $\mathrm{N}$ uptake by a growing crop or periodic subsampling of incubated soil). 
Nevertheless, we hypothesize that decomposed cotton residues would accelerate nutrient release and be more suitable for plant growth and the availability of $\mathrm{N}$ can be predicted from the simultaneous long term incubation of the compost and vermicompost used in the pot trails.

\section{2. $\underline{\text { Aims }}$}

To integrate compost and vermicompost in crop production from an economic as well as ecological point of view, the exploitation of the applied nutrients should be known. However, research on the $\mathrm{N}$ mineralization from cotton residues and its impact on crop nutrition are fairly limited, our objectives were:

$\checkmark$ to evaluate the agronomic value of compost and vermicompost after single application.

$\checkmark$ to determine whether aerobic incubation provide an adequate index of $\mathrm{N}$ availability to estimate agronomically acceptable rates of compost and vermicompost applications.

$\checkmark$ to assess mineralized nitrogen from the compost and vermicompost obtained by aerobic incubation test.

\subsection{Materials and methods}

Cotton residues was mixed with soil and farm yard manure (FYM) for composting (CPF) in 5:1:1 on dry weight basis of cotton residues, farm yard manure (FYM) and soil, respectively. The vermicomposting was prepared with the same initial materials without FYM (VER) in a ratio 5:1 of cotton residues to soil, respectively, and then inoculated with earthworms (Lumbricus terrestris). Water was added to the mixture to give a moisture content of $65-75 \%$ of the total water holding capacity by dry weight and kept within this range by adding water when needed. Every two weeks, the materials were turned and the outer materials moved to the center of the silo for homogeneity. Soil samples were collected from the top 0-30 $\mathrm{cm}$ depth native areas of Gezira irrigated farming system, Sudan. Soil samples were air dried, passed through a 2-mm sieve to exclude non soil particles, and then analyzed for chemical and physical properties (Adam 
\& Farbrother, 1975; Porter \& McMahon, 1987). The chemical properties of the soil, compost, and vermicompost used in this part were described in the previous chapter.

\subsubsection{Methods}

\subsubsection{Greenhouse Study}

In an attempt to ascertain comparatively the effectiveness of the compost and vermicompost on plant yield, ryegrass (Lolium perenne L.) was grown in a greenhouse in pots. Ryegrass is a suitable test plant because the crop is highly sensitive to the presence of organic compounds, highly responsive, grows rapidly, and enables several harvests over an extended growing period (Sarwar et al., 2003). Different amounts of compost and vermicompost have been applied to the pots. For the pots amended with compost, $796.7 \mathrm{~g}$ $\mathrm{DM}^{-1}$ of the composted cotton residues with FYM (CPF1) and $1593.4 \mathrm{~g} \mathrm{DM}^{-1}$ and 1593.4 $\mathrm{g} \mathrm{DM}^{-1}$ of CPF2, respectively have applied. For the vermicomposted amended pots, 794.5 $\mathrm{g}$ and $1589.0 \mathrm{~g} \mathrm{DM}^{-1}$ for VER1 and VER2, respectively, have been applied. Both added amounts of compost and vermicompost were corresponding to 4 and $8 \mathrm{~g} \mathrm{~N} \mathrm{pot}^{-1}$, respectively. Amendments were applied once prior to planting.

Soil was mixed thoroughly with sand in 1:1. The mixture of sand and soil was mixed with the compost or vermicompost. A $2.6 \mathrm{~g}$ of triple super phosphate (TSP) $(0.5 \mathrm{~g} \mathrm{P})$ was added to vermicompost to compensate the difference in $\mathrm{P}$ concentration. Amended soils in addition to the non-amended control were placed in $5 \mathrm{~kg}(\varnothing 20.5 \mathrm{~cm})$ pots. The surface of the mixture in the pots was lightly tapped down to facilitate seed sowing. Ryegrass seed (2.5 g) was sown in each pot in May 2007 and watered. Pots were placed in a complete randomized design (CRD) replicated four times. After the germination, soil moisture content was adjusted to $70 \%$ of the maximum water holding capacity and moisture content was daily controlled by weighing and readjusting throughout the experiment by watering. Pots were maintained in a greenhouse at the Department of Crop Sciences - Georg-August University, Göttingen under natural lighting and ambient temperature.

Harvesting of the aerial parts was conducted 10 days after seedlings emergence and then every 10 days intervals towards the end of the experiment. The experiment ended for 
eight consecutive harvests because plant biomass was too hard to harvest. Aerial parts of the plants were cut $2 \mathrm{~cm}$ above the surface of the soil, put into paper bags and dried in a forced-air oven at $60{ }^{\circ} \mathrm{C}$ for $72 \mathrm{~h}$, weighted, and ground prior to nutrient content analysis.

Dry weight, nitrogen and phosphorus contents of the plant materials at each harvest were determined. The yield of the control for the fourth harvest interval and subsequent sampling dates (after 40 days) was extremely low and not sufficient for the analysis.

\subsubsection{Chemical Analyses}

Plant materials were analyzed as follow; total $\mathrm{N}$ and carbon were determined according to the dry combustion method using CHNS analyzer system (Model VARIO MAX Elementar Analyses System, GmbH, Hanau, Germany). Phosphorus (P) was determined by the Vanadate-Molybdate-Yellow method (Chapman \& Pratt, 1962). Data of the fourth and eighth harvests (40 and 80 days after seedlings emergence) were not shown because plant material was insufficient to conduct the analysis.

Nitrogen uptake was calculated by multiplying the biomass of plant by its $\mathrm{N}$ concentration at each harvest. Net $\mathrm{N}$ uptake (NNUP) and apparent $\mathrm{N}$ recovery (ANR) of the added $\mathrm{N}$ during the first four harvests were calculated as describe by Dilz (1988) equation $6.1 \& 6.2$ ).

$$
\operatorname{ANR}(\%)=\frac{(\mathrm{N}-\text { uptake in treatment })-(\mathrm{N}-\text { uptake in control })}{\mathrm{N} \text { applied in treatment }} \times 100
$$

NNU $\quad=(\mathrm{N}-$ uptake in treatment $)-(\mathrm{N}-$ uptake in control $)$

\subsubsection{Long-term laboratory incubation}

For the aerobic $\mathrm{N}$ incubation experiment, the soil used in the pot experiment has been incubated; using a procedure described by Nordmeyer and Richter (1985), with some adjustments as follows (method described here was adopted by Heumann et al. (2002)).

The soil and mixtures of the pot experiment has been incubated, where soil mixtureequivalent to $20 \mathrm{~g}$ oven-dry soil was mixed with $15 \mathrm{~g}$ acid-washed coarse sand (four replicates). The soil-sand-mixture was filled into syringes with a volume of $50 \mathrm{ml}$ and 
then covered with $20 \mathrm{~g}$ of acid-washed coarse sand. Samples were leached with $120 \mathrm{ml}$ of $0.02 \mathrm{M} \mathrm{CaCl}_{2}$ prior to incubation in order to remove all mineral $\mathrm{N}$ contained in the soil. After the leaching procedure, $25 \mathrm{ml}$ minus-N nutrient solution $\left(0.002 \mathrm{M} \mathrm{CaSO}_{4} \cdot \mathrm{H}_{2} \mathrm{O}\right.$; $0.002 \mathrm{M} \mathrm{MgSO}_{4} ; 0.005 \mathrm{M} \mathrm{Ca}\left(\mathrm{H}_{2} \mathrm{PO}_{4}\right)_{2} \cdot \mathrm{H}_{2} \mathrm{O}$; and $0.0025 \mathrm{M} \mathrm{K}_{2} \mathrm{SO}_{4}$ ) (Stanford \& Smith, 1972) were added. Water contents of the mixture (sand, soil and organic materials) were adjusted to 50 to $60 \%$ water-filled pore-space (WFPS) by suction, which was controlled by measuring sample volume and weight of the syringe. Samples were incubated at $35^{\circ} \mathrm{C}$ for at least 200 days. Leaching was done with $120 \mathrm{ml}$ of $0.02 \mathrm{M} \mathrm{CaCl}_{2}$ in 6 to 8 intervals increasing with time (about 1, 2, 4, 7, 7, 7 weeks), followed by addition of minus-N nutrient solution and adjustment of water contents as described above. Mineralized $\mathrm{NO}_{3}$ $\mathrm{N}$ and $\mathrm{NH}_{4}-\mathrm{N}$ were determined in the leachates (except for day 0 ) following the Bremner procedure (1965). Total mineral $\mathrm{N}$ was taken as the summation of $\mathrm{NO}_{3}-\mathrm{N}$ and $\mathrm{NH}_{4}-\mathrm{N}$. However, net $\mathrm{N}$ mineralization/immobilization (positive values indicate mineralization, while negative values indicate immobilization) from amended soils was determined by subtraction of total mineral $\mathrm{N}$ of the control at the end of the incubation period from the equivalent value of each amended soil. All analyses were carried out in four replicates.

Pot experimental data was correlated with data from the incubation results.

\subsection{Statistical analysis}

The data were statistically analyzed with SAS System for Windows. Analysis of variance (ANOVA) was used to determine the significance of the treatments (compost and vermicompost rates and time). Mean separation was performed using Least Significant Difference (LSD) at a probability level of $₫ \mathbf{0 . 0 5}$, unless otherwise stated. Multiple correlations between growth parameters were conducted as well as between mineralizable $\mathrm{N}$ and plant $\mathrm{N}$ uptake using SAS 9.0 (SAS Institute, 2000). 


\subsection{Results and discussions}

\subsubsection{Ryegrass growth responses}

\subsubsection{Plant biomass}

The experiment lasted three months and all pots were harvested eight times after single application of either compost or vermicompost to the soil. For both compost and vermicompost, there were considerable differences in biomass yield among pots amended with compost and vermicompost at the first three harvests; therefore, the growth responses of ryegrass as measured by total dry biomass depend on the source of nutrients.

For the vermicompost, different rates applied had different effects on ryegrass biomass. The higher biomass of pots amended with vermicompost rate corresponding to $4 \mathrm{~g} \mathrm{~N}$ pot $^{-1}$ (VER1) was recorded for the first harvesting date followed by the second, then significant decreased thereafter at 30 days, but slightly increased thereafter where remained relatively constant up to 70 days after seedlings emergence, and significantly decreased $(P<0.0001)$ at the end of experiment (Fig. 6.1B). The first harvest gave the highest yield while the last gave the lowest, $1.4 \mathrm{~g} \mathrm{~kg}^{-1}$ and $0.2 \mathrm{~g} \mathrm{~kg}^{-1}$, respectively.

The first harvest of biomass was significantly higher $(P<0.001)$ in the vermicompost corresponding to $4 \mathrm{~g} \mathrm{~N}$ pot $^{-1}$ (VER1) than the rate corresponding to $8 \mathrm{~g} \mathrm{~N}$ pot $^{-1}$ (VER2) but the reverse occurred at 20 days onwards where, vermicompost rate corresponding to 8 $\mathrm{g} \mathrm{N} \mathrm{pot}^{-1}$ significantly $(P<0.03)$ increased. The harvested biomass at 30 significantly decreased compared to biomass yield at 20 and had a relatively constant reduction up to the end of the experiment. The higher biomass yield was at the second harvest and the lowest at the last harvest, 0.9 and $0.2 \mathrm{~g} \mathrm{~kg}^{-1}$, respectively.

Although the biomass for the first harvest (10 days after seedlings emergence) was higher in the vermicompost corresponding to $4 \mathrm{~g} \mathrm{~N}$ pot $^{-1}$, the harvested biomass in pots amended with vermicompost corresponding to $8 \mathrm{~g} \mathrm{~N} \mathrm{pot}^{-1}$ was significantly higher $(P<0.05)$ for the second harvest. At the other harvest dates, the difference remained relatively higher in pots amended with vermicompost corresponding to $8 \mathrm{~g} \mathrm{~N} \mathrm{pot}^{-1}$ but with no significance $(P>0.05)$ from those harvested from pots amended with vermicompost corresponding $4 \mathrm{~g}$ $\mathrm{N}_{\text {pot }}{ }^{-1}$, where biomass was lower in the later (Fig. 6.1B). 
For both rates of vermicompost, biomass yields declined sharply after the second harvest and the significant differences was only calculated for the first and the second harvests and remained slightly different with no significant differences at the other harvests (Fig 6.1B). The highest biomass yield was confined to the first and the second harvests.

Ryegrass biomass yield in compost amended pots showed clear patterns related to application rates; increasing the amount of compost from 4 to $8 \mathrm{~g} \mathrm{~N}$ pot $^{-1}$ significantly increased plant dry biomass, indicating that available nutrients promote plant growth.

Regarding yield comparisons among individual harvests, biomass yield from the compost amended pots showed that, the greater biomass was harvested with compost rate corresponding to $8 \mathrm{~g} \mathrm{~N}^{-1}$ pot $^{-1}(\mathrm{CPF} 2)$ compared to ryegrass sown in pots amended with compost rate corresponding to $4 \mathrm{~g} \mathrm{~N} \operatorname{pot}^{-1}$ (CPF1). The differences were highly significant $(P<0.0001)$ for the first up to the harvest at 60 days, significant $(P<0.05)$ for the second harvest, while the two last harvests were not significant (Fig. 6.1A).

For pots amended with compost corresponding to $4 \mathrm{~g} \mathrm{~N}$ pot $^{-1}$ (CPF1), the first harvested biomass (after 10 days after seedlings emergence) was higher and progressively decreased with time towards the end of the experiment. The reduction in biomass yield was highly $(P<0.0001)$ significant between the second and third, the third and the fourth, and the sixth and the seventh harvest, respectively. Harvest at 40 days remained relatively constant up to the harvest at 60 days but then significantly decreased $(P<0.0001)$ at 60 days. The first and the last harvests, gave the highest and the lowest yields, 1.8 and $0.14 \mathrm{~g}$ $\mathrm{kg}^{-1}$, respectively (Fig 6.1A).

Concerning the pots amended with compost corresponding to $8 \mathrm{~g} \mathrm{~N}^{-1}$ (CPF2), the first harvested biomass was significantly $(P<0.05)$ different from that observed for the rate corresponding to $4 \mathrm{~g} \mathrm{~N}^{-1}$ (CPF1), but significantly increased in the harvest at 20 days. Thereafter, the biomass yield slightly decreased at 30 and further decreased with significance $(P<0.0001)$ at 40 days, where remained with no significant change up to the harvest at 60 days, but significantly decreased further at 70 days and remained relatively constant towards the end of the experiment (Fig. 6.1B ). 
Comparing compost rates of application, compost corresponding to $8 \mathrm{~g} \mathrm{~N}$ pot $^{-1}$ (CPF2) gave at most of the harvest dates significant $(P<0.05)$ higher biomass compared to biomass harvested from pots amended with the lower rate. The highest biomass harvested from compost amended pots was during the first three consecutive harvests while the lowest was observed at the last two harvests.

For compost and vermicompost, the higher biomass yield corresponding to the first and the second harvest was due to a considerable tillering and development of the crop after the first two stimulating cuts (Fig 6.1A \& B) (Coutinho et al., 1997). Observed reduction in yield in all treatments at 30 days onwards, seems to be the result of an extreme shortage of available $\mathrm{N}$ to the ryegrass especially for pots amended with vermicompost. This suggestion was pronounced in the vermicompost and was further supported by the visual signs of $\mathrm{N}$ deficiency (chlorosis) (Marschner, 1995; Tucker, 1984).

Differences in biomass yield were mainly due to different materials used (compost and vermicompost), and also to the applied rates. At each rate, pots amended with compost gave biomass triple the amount harvested from the vermicompost amended pots especially for harvests at 30, 40, 50, and 60 days. Addition of FYM to the compost was probably the main reason for the observed differences. This result is in agreement with Eghball and Power (1999), who reported that application of compost at higher doses increases the $\mathrm{N}$ availability to plants and consequently dry biomass per pot differed significantly.

Increase in biomass yield due to the increase in amendment rates was reported by Smith and Tibbett (2004), where effect of single application of either fertilizers or biosolids was also reported. Their results showed that $6-75 \%$ of $\mathrm{N}$ and $1.2-7 \%$ of $\mathrm{P}$ applied as biosolids were recovered in plants biomass depending on soil type (Corrêa, 2004).

Results from this work are in accordance with other workers, for instance, Nwachukwu and Pulford (2009) who stated that additions of amendments led to increased biomass yield in all soils when compared with the non-amended soil (control), in our study control data were confined for the calculation of net nitrogen uptake and apparent nitrogen uptake percentage ,that will be illustrated later, because biomass harvested from the 
control pots was too hard to be collected after the fourth harvest (data not shown). However, our results were in accordance with Nwachukwu and Pulford (2009) who reported that, all ryegrass harvested from amended soils had greater $\mathrm{N}$ content than the control.

The reduction in biomass yield at 30 days onwards for the vermicompost amended pots and at the last three harvests for the compost amended pots could be due to the limited available $\mathrm{N}$; the reduction in ryegrass biomass yield was also reported by Coutinho et al. (1997) where the composted sewage sludge rates did not increase soil mineral N, ryegrass dry matter, and $\mathrm{N}$ uptake and they concluded that mineralized $\mathrm{N}$ was not adequate for normal growth of ryegrass.
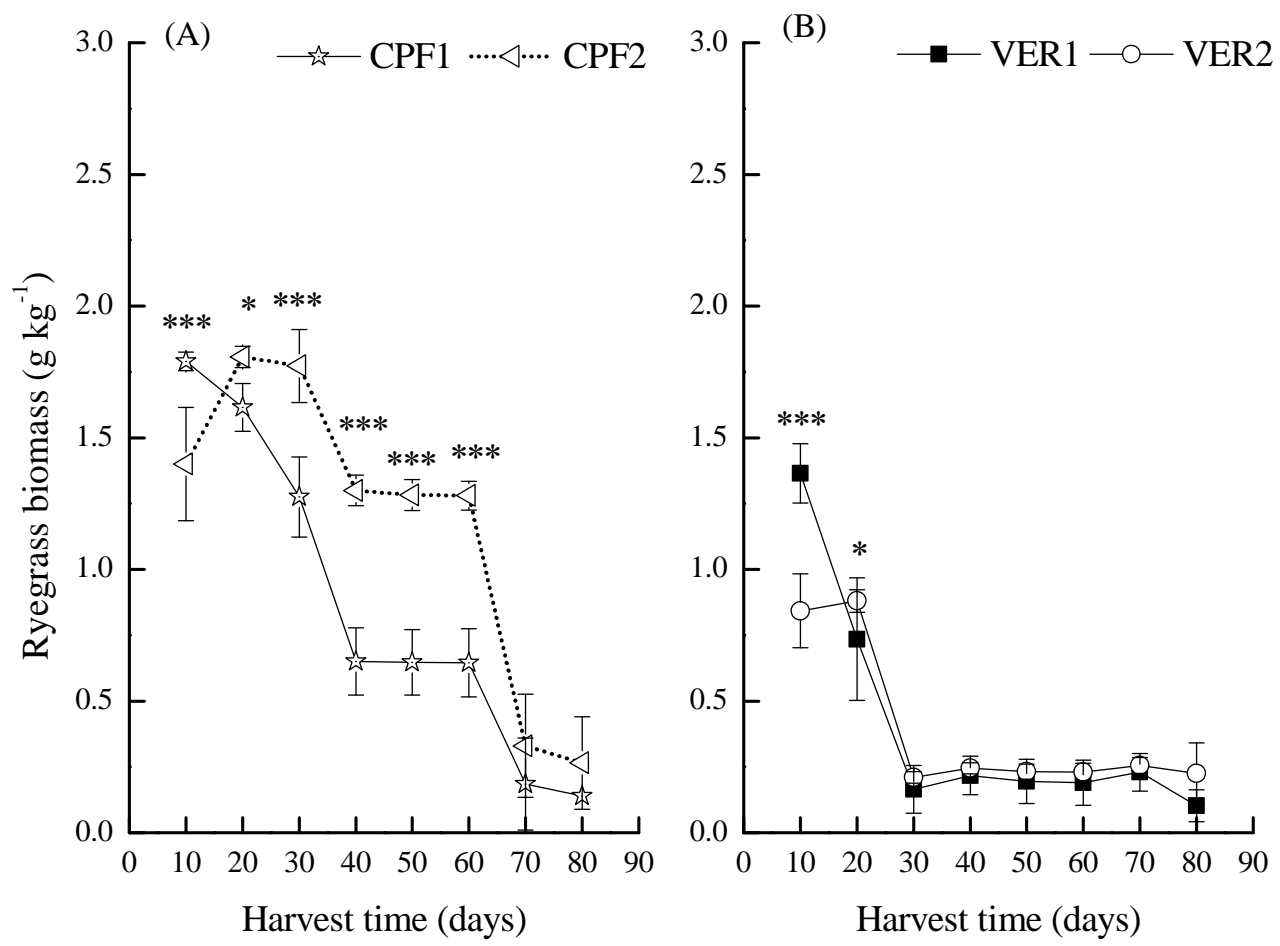

Fig 6.1. Effect of compost (A) and vermicompost (B) application rates on ryegrass consecutive biomass harvests. $\mathrm{X}$-axis refers to the different harvests at different days after seedlings emergence. CPF1 and VER1: compost and vermicompost corresponding to $4 \mathrm{~g} \mathrm{~N}^{-1}(121.3 \mathrm{~g} \mathrm{~N}$ $\left.\mathrm{m}^{-2}\right)$; CPF2 and VER2: corresponding to $8 \mathrm{~g} \mathrm{~N}^{-1} \operatorname{pot}^{-1}\left(242.6 \mathrm{~g} \mathrm{~N} \mathrm{~m}^{-2}\right)$. Means within the same sampling date following with $* * *$, and $* * *$ are significantly different at $P<0.05,<0.01$, and $<0.001$, respectively. 


\subsubsection{Ryegrass total $N$}

Ryegrass total $\mathrm{N}$ followed the same trend as observed in the biomass (Fig.6.1A \& $\mathrm{B}$ ), where, $\% \mathrm{~N}$ of ryegrass sown on pots amended with compost corresponding to $8 \mathrm{~g} \mathrm{~N} \mathrm{pot}^{-1}$ was significantly $(P<0.05)$ higher at all harvests except for harvests at 10, 60 and 70 days. For both rates, the first harvest gave the highest $\% \mathrm{~N}$ and the last harvest gave the lowest \% N (Fig. 6.2A).

For the pots amended with compost corresponding to $4 \mathrm{~g} \mathrm{~N} \operatorname{pot}^{-1}$ (CPF1), the reduction in $\% \mathrm{~N}$ with time was inconsistent. The highest $\% \mathrm{~N}(6.1 \%)$ was measured at 10 days, significantly $(P<0.0001)$ decreased at 20 and 30 days, and further decreased at 50 days. After 70 days of seedlings emergence, the $\% \mathrm{~N}$ significantly increased $(P<0.0001)$, but decreased at 70 where remained relatively constant at the last two sampling dates (Fig. $6.2 \mathrm{~A})$, where the lowest $\% \mathrm{~N}$ value $(2.9 \%)$ was recorded.

In pots amended with compost corresponding to $8 \mathrm{~g} \mathrm{~N}$ pot $^{-1}(\mathrm{CPF} 2)$, the higher $\% \mathrm{~N}$ was at 10 days and progressively and significantly $(P<0.05)$ decreased with time up the 50 days where significantly $(P<0.0001)$ increased at 60 days, and then significantly decreased at the end of the experiment period (Fig. 6.2A). The $\% \mathrm{~N}$ values at 10 and 80 days were 6.4 and $2.4 \%$.

Concerning pots amended with vermicompost (VER1 \& VER2), no significant difference $(P>0.05)$ was observed between the application rates. For both rates, the highest $\% \mathrm{~N}$ was measured at 10 days and the lowest at the last sampling date (Fig. 6.2B).

For vermicompost corresponding to $4 \mathrm{~g} \mathrm{~N}$ pot $^{-1}$ amended pots, the highest $\% \mathrm{~N}$ was at 10 days significantly $(P<0.0001)$ decreased at 20 days, remained relatively constant up to 50 days, then significantly $(P<0.0001)$ increased at 60 and 70 , but significantly decreased at 80 days, where the lowest $\% \mathrm{~N}$ was measured (Fig.6. 2B). The first and the last sampling dates gave $\% \mathrm{~N}$ values of 3.7 and $1.9 \%$, respectively.

Whereas for pots amended with vermicompost corresponding to $8 \mathrm{~g} \mathrm{~N}$ pot $^{-1}$, typically followed the same trend of pots amended with lower vermicompost lower rate (VER1). The highest $\% \mathrm{~N}$ was at 10 days and the lowest at 80 days, where, the values were $4.0 \%$ for former and $2.1 \%$ for the later, respectively (Fig. 6.2B). 
(A)

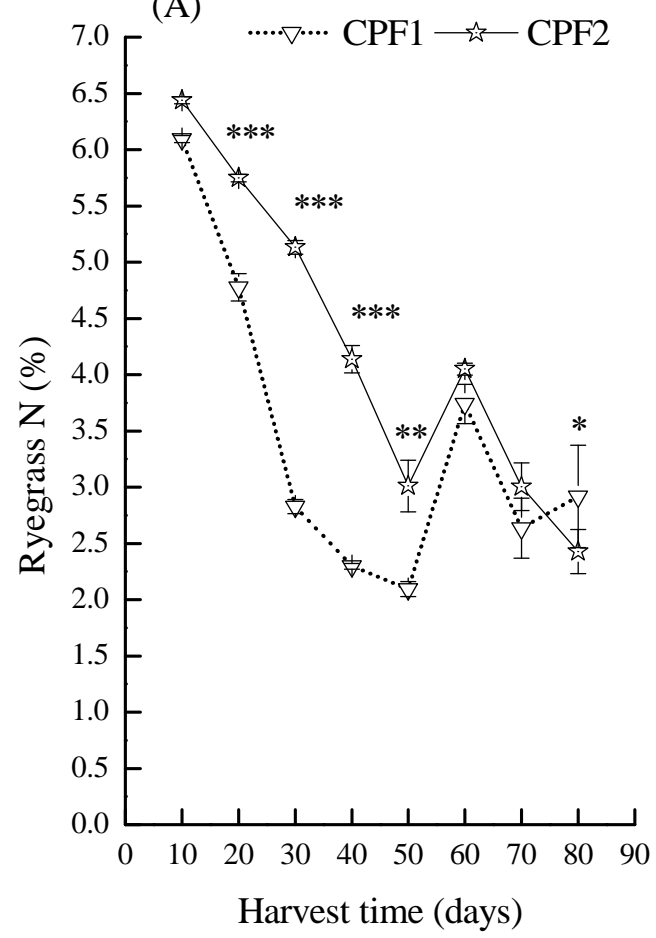

(B)

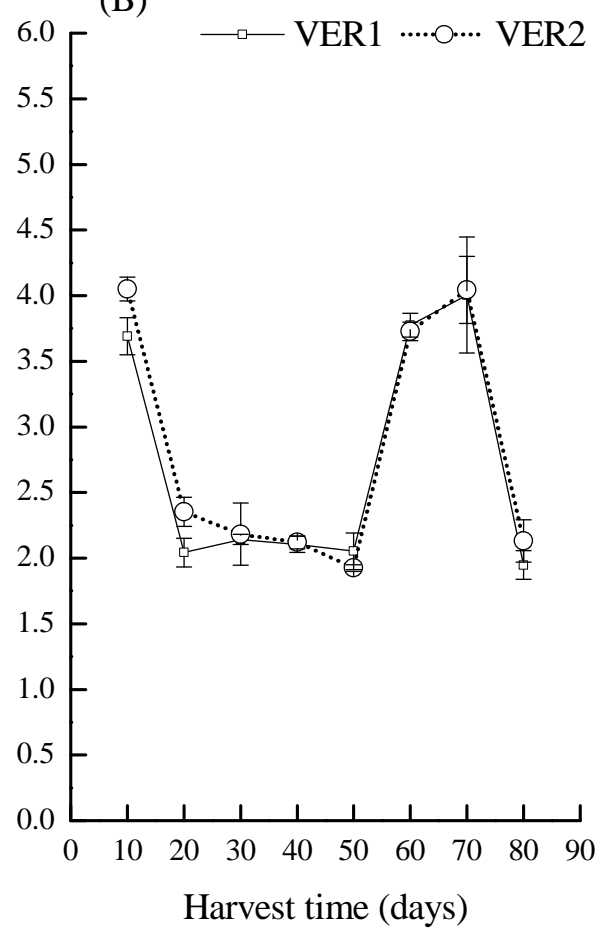

Fig.6.2. Effect of compost (A) and vermicompost (B) application rates on aboveground ryegrass $\mathrm{N}$ content $\mathrm{X}$-axis refers to the different harvests at different days after seedlings emergence. $\mathrm{CPF} 1$ and VER1: compost and vermicompost corresponding to $4 \mathrm{~g} \mathrm{~N}^{-1} \operatorname{pot}^{-1}\left(121.3 \mathrm{~g} \mathrm{~N} \mathrm{~m}^{-2}\right)$; CPF2 and VER2: corresponding to $8 \mathrm{~g} \mathrm{~N}$ pot $^{-1}\left(242.6 \mathrm{~g} \mathrm{~N} \mathrm{~m}^{-2}\right)$. Means within the same sampling date following with $*, * *$, and $* * *$ are significantly different at $P<0.05,<0.01$, and $<0.001$, respectively. 
At all sampling dates, $\mathrm{N}$ content in plants grown in pots amended with compost corresponding to $8 \mathrm{~g} \mathrm{~N}^{-1}$ (CPF2) are within the sufficiency levels (3-4.2\%) of $\mathrm{N}$ for the normal growth of Lolium spp. reported by Bergmann, (1992) except for the last one, and even are within the higher range (4.5-5.0\%) stated by Benton Jones et al. (1991) especially during the first three harvests. Nitrogen content of the compost amended pots corresponding to $4 \mathrm{~g} \mathrm{~N} \mathrm{pot}^{-1}$ are within the first stated optimum range for harvests at 10 , 20, and 60 days. These results are in agreement with Eghball and Power (1999) who reported that application of compost at higher doses increases the $\mathrm{N}$ availability to plants.

The $\mathrm{N}$ content of ryegrass sown on pots amended with vermicompost, which fell within the sufficiency range, is at 10, 60, and 70 days. The failure of vermicompost to supply sufficient $\mathrm{N}$ to ryegrass for more than $60 \%$ of experiment period is in accordance with the studies of Coutinho et al. (1997) who concluded that mineralized $\mathrm{N}$ was not adequate for normal growth of ryegrass.

Overall, compost corresponding to $8 \mathrm{~g} \mathrm{~N}$ pot $^{-1}$ was the only treatment successfully supplied ryegrass with sufficient $\mathrm{N}$ up the harvest at 70 days; while vermicompost rates were not able to supply sufficient $\mathrm{N}$ for most of the experiment period.

\subsubsection{Apparent $\mathrm{N}$ recovery $\%(\mathrm{ANR})$ and net $\mathrm{N}$ uptake (NNUP)} Apparent nitrogen recovery was calculated as described by Ditz (Dilz, 1988) (equation $6.1 \& 6.2$ ). Data of the apparent nitrogen recovery and net $\mathrm{N}$ uptake was confined to the first four harvests (up to 40 days) because materials in control pots were too hard to harvest, this was because biomass yield in subsequent harvests seems to be the result of an extreme shortage of available $\mathrm{N}$ to ryegrass since this soil is characterized with low $\mathrm{N}$ content in addition to the control pots contained a ratio of $1: 1(\mathrm{w} / \mathrm{w})$ of soil and quartz sand because soil quantities was insufficient for all experiment pots.

Treatments had different effects on crop $\mathrm{N}$ efficacy. Nitrogen uptake varied considerably depending on treatment and rate of application and was strongly correlated with yield ( $r=$ $0.9 ; P<0.0001)$. Accordingly, with biomass yield and $\mathrm{N}$ content, significant differences in apparent $\mathrm{N}$ recovery was calculated; the overall mean of the apparent $\mathrm{N}$ recovery was higher in pots amended with compost compared to that with vermicompost. 
For the individual comparisons of the apparent $\mathrm{N}$ recovery, the apparent $\mathrm{N}$ recovery of pots amended with compost corresponding to $4 \mathrm{~g} \mathrm{~N}^{-1}$ (CPF1) was higher at 10 days $(8.0 \%)$ but significantly $(P<0.001)$ and progressively decreased at 40 days $(1.2 \%)$. Conversely, the apparent $\mathrm{N}$ recovery of pots amended with compost corresponding to $8 \mathrm{~g}$ $\mathrm{N}_{\text {pot }}{ }^{-1}$ (CPF2) increased with high significance at 20 days, but significantly decreased at 30 and 40 days. The highest and the lowest values of apparent $\mathrm{N}$ recovery were 5.3 and $2.8 \%$ at 20 and 40 days, respectively (Fig. 6.3A).

For pots amended with vermicompost, the same trend as observed in the compost amended pots regarding the highest and the lowest values of apparent $\mathrm{N}$ recovery and the reduction with time was more pronounced. Pots amended with vermicompost corresponding to $4 \mathrm{~g} \mathrm{~N}$ pot $^{-1}$ gave an apparent $\mathrm{N}$ recovery of $3.2 \%$ at 10 days, significantly $(P<0.0001)$ decreased to $1.0 \%$ at 20 days, and further declined to $0.3 \%$ where remained equal to the value at 40 days (Fig. 3B). Lower values were calculated for the pots amended with vermicompost corresponding to $8 \mathrm{~g} \mathrm{~N} \mathrm{pot}^{-1}$, where the highest and the lowest values were 1.3 and $0.2 \%$ at 10 and 40 days, respectively. The reduction in the apparent $\mathrm{N}$ recovery values of this case was significantly and gradually with time (Fig. $6.3 \mathrm{~B})$.

Differences in the apparent $\mathrm{N}$ recovery between compost applied rates were significant across all dates, where the values of the lower rate (CPF1) was higher during the first 20 days but at 30 and 40 days, values calculated from pots amended with compost corresponding with $8 \mathrm{~g} \mathrm{~N}_{\text {pot }}{ }^{-1}$ (CPF2) were significantly higher. The difference between vermicompost rates was only significant at 10 days and values remained almost the same thereafter.

The calculated cumulative apparent $\mathrm{N}$ recovery (as sum of the four values) values were 3.0 and $5.0 \%$ for pots amended with vermicompost corresponding to $8 \mathrm{~g} \mathrm{~N}$ pot $^{-1}$ (VER2) and pots amended with vermicompost corresponding to $4 \mathrm{~g} \mathrm{~N}_{\text {pot }}{ }^{-1}$ (VER1), respectively. These values reflect that the recovery of $\mathrm{N}$ by the ryegrass was extremely poor where > 90.0\% was not utilized, while the values were higher for pots amended with compost (18\%) but still more than $80 \%$ of the applied $\mathrm{N}$ was not recovered by the crop. 
Although this calculation reflects the efficacy of the ryegrass in $\mathrm{N}$ uptake as $\mathrm{N}$ percentage of the $\mathrm{N}$ applied, but led the impractical comparisons between rates; the higher values of apparent $\mathrm{N}$ recovery recorded for the lower rates of both compost and vermicompost amended pots are due to the high value used in the denominator during calculation, where for the lower rates equivalence to $4 \mathrm{~g} \mathrm{~N}$ pot $^{-1}$ were used while $8 \mathrm{~g} \mathrm{~N}$ pot $^{-1}$ was used for the higher application rate. This difference in the denominator overwhelmed the difference between the rates applied. Therefore, we recalculated the values using the net $\mathrm{N}$ uptake (NNUP) (equation 6.2).

Throughout the four harvests across the treatments, the net $\mathrm{N}$ uptake was higher in pots amended with materials corresponding to $8 \mathrm{~g} \mathrm{~N} \mathrm{pot}^{-1}$ especially for the compost rates.

Concerning the compost, pots amended with compost corresponding $4 \mathrm{~g} \mathrm{~N}_{\text {pot }}{ }^{-1}$ was higher at 10 days but significantly $(P<0.0001)$ decreased with time. The highest and the lowest values were 93.5 and $14.2 \mathrm{mg} \mathrm{N} \mathrm{kg}^{-1}$ for harvests at 10 and 40 days, respectively. The net $\mathrm{N}$ uptake for pots amended with compost corresponding $8 \mathrm{~g} \mathrm{~N}$ pot $^{-1}$ (CPF2) was low at 10 days and significantly increased at 20 days, but significantly declined at 40 days where the lowest value $\left(53.1 \mathrm{mg} \mathrm{N} \mathrm{kg}^{-1}\right)$ was recorded. The differences between both rates were highly significant $(P<0.001)$ across harvest dates except for the harvest at 10 days where the value of the higher application rate $(\mathrm{CPF} 2)$ was significantly lower comparing to that of the lower application rate (CPF1) (Fig. 6.4A).

Regarding pots amended with vermicompost, the net $\mathrm{N}$ uptake of pots amended with $8 \mathrm{~g}$ $\mathrm{N} \mathrm{pot}^{-1}$ (VER2) was relatively higher than the lower application (VER1) rate across all harvests except for the first one, where the value was significantly $(P<0.0001)$ significantly higher than that reported for the pots amended with $4 \mathrm{~g} \mathrm{~N}$ pot $^{-1}$ (VER1) . The only significant $(P<0.05)$ difference found was at 10 and 20 days after seedling emergence. The net $\mathrm{N}$ uptake of pots amended with vermicompost corresponding to $4 \mathrm{~g}$ $\mathrm{N} \operatorname{pot}^{-1}$ (VER1) was higher at 10 days, significantly $(P<0.0001)$ decreased at 20 days, and further declined at the following two harvests. The highest and the lowest values recorded were 34.6 and $3.3 \mathrm{mg} \mathrm{kg}^{-1}$ at 10 and 30 days, respectively (Fig. 6.4B). 
For pots amended with vermicompost corresponding to $8 \mathrm{~g} \mathrm{~N} \operatorname{pot}^{-1}$ (VER2), the net $\mathrm{N}$ uptake at 10 days was $18.4 \mathrm{mg} \mathrm{kg}^{-1}$, decreased to $16.4 \mathrm{mg} \mathrm{kg}^{-1}$, and significantly $(P<$ $0.001)$ decreased at 30 and 40 days where the lowest values were calculated $\left(4.4 \mathrm{mg} \mathrm{kg}^{-1}\right.$, for both harvest dates) (Fig. 6.4B).

The absence of significant differences in net $\mathrm{N}$ uptake between vermicompost corresponding to $8 \mathrm{~g} \mathrm{~N}^{-1}$ (VER2) and pots amended with the same material corresponding to $4 \mathrm{~g} \mathrm{~N}$ pot $^{-1}$ (VER1) across all harvests except for the harvest at 10 and 20 days, was due to the almost equal biomass yield and $\mathrm{N}$ content.

The positive response of ryegrass to the application rates of organic residues in terms of biomass yield and $\mathrm{N}$ content has been reported by Smith and Tibbet (2004), accordingly, the net $\mathrm{N}$ uptake values of this study clearly explained the pattern of $\mathrm{N}$ uptake, where this pattern was more pronounced in compost amended pots. Although the net $\mathrm{N}$ uptake led to better evaluation of the application rates within the same materials, however, it gives limited information concerning the agronomical value of the materials used.

Overall, values of apparent net $\mathrm{N}$ uptake indicated that the amount of available $\mathrm{N}$ derived from the amended pots was relatively large in compost and much smaller in vermicompost.

Reported studies have shown that, different organic residues increased ryegrass yield, $\mathrm{N}$ and N uptake (Smith \& Peterson, 1982; Smith \& Tibbet, 2004). Different N recovery values to evaluate crop efficiency depend on the raw materials and composting type have been recorded. Compost amended pots data are in agreement with results of Corrêa (2004) who reported a value $>17 \%$ of the applied $\mathrm{N}$ as composted biosolids was recovered in the plant tissue; while the values of the vermicompost are far below the above mentioned value. Dry matter yields and $\mathrm{N}$ uptake by Italian ryegrass were higher by around $20 \%$ on organically managed soil than mineral fertilized soil due to a significantly greater $\mathrm{N}$ supply (Langmeier et al., 2002).

The low $\mathrm{N}$ efficiency of the decomposed cotton residues of this experiment can be attributed to its low mineralization rate. Thus, the incorporation of these materials into the soil resulted in approximately $80 \%$ of the $\mathrm{N}$ not being utilized by ryegrass after eight 
consecutive harvests; the remaining $\mathrm{N}$ could be considered as residual, since cotton residues had high lignin (16.2\%), cellulose (36.5) and hemicellulose (19\%) which will result in low net $\mathrm{N}$ mineralization and plant uptake in the first cropping season, but may produce greater residual effect in subsequent seasons (Myers et al., 1994).

Beside the high lignin content residues with less than 1-1.2\% $\mathrm{N}$ usually immobilize $\mathrm{N}$ (Vigil \& Kissel, 1991). The failure of ryegrass to recover more $\mathrm{N}$ can also be explained by the $\mathrm{N}$ immobilization (Aitken et al., 1998; Bellamy et al., 1995; Douglas et al., 2003). There is good evidence that earthworms promote microbial activity and diversity in organic wastes to levels even greater than those in thermophilic composts (Edwards, 1998a; Edwards et al., 2010; Yardim et al., 2006); consequently, the extremely low N recovery values recorded for the vermicompost amended pots may be due to the active microbial biomass with greater $\mathrm{N}$ demand, thus promoting immobilization. 

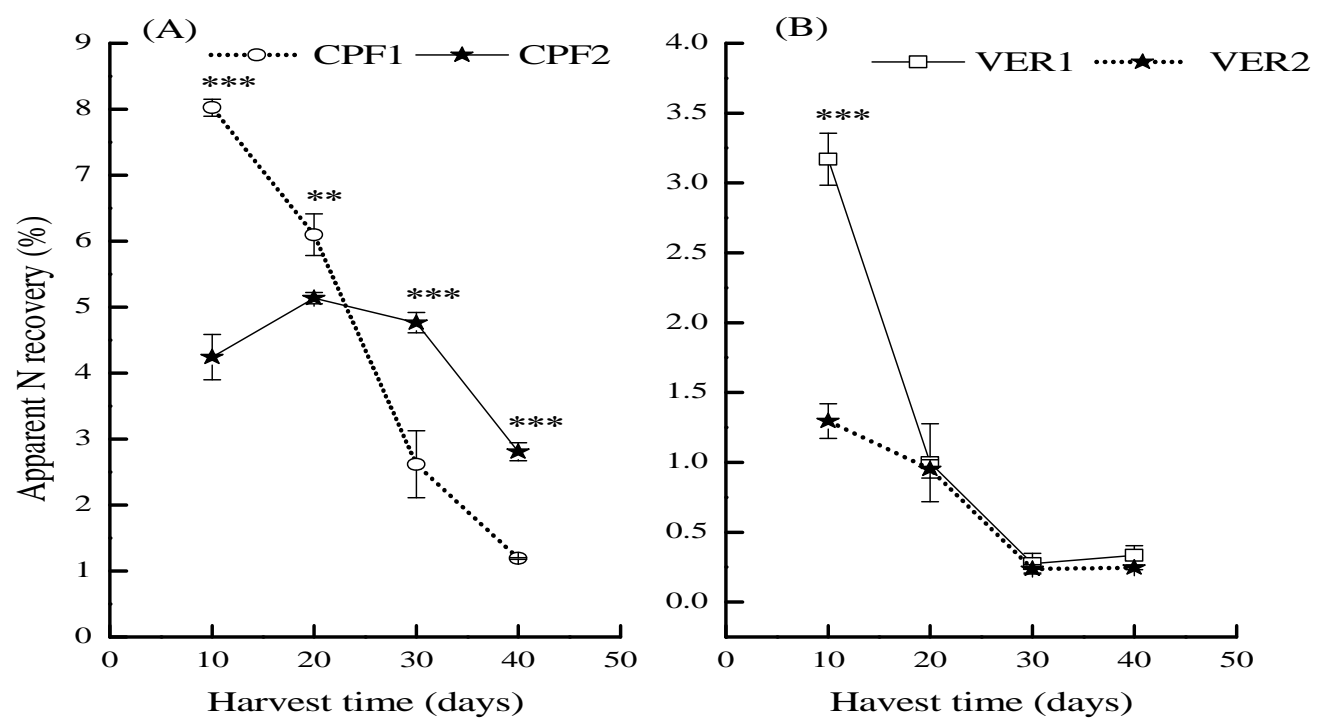

Fig.6.3. Effect of compost (A) and vermicompost (B) application rates on ryegrass apparent $\mathrm{N}$ recovery. $\mathrm{X}$-axis refers to the different harvests at different days after seedlings emergence. $\mathrm{CPF} 1$ and VER1: compost and vermicompost corresponding to $4 \mathrm{~g} \mathrm{~N}^{-1}\left(121.3 \mathrm{~g} \mathrm{~N} \mathrm{~m}^{-2}\right)$; CPF2 and VER2: corresponding to $8 \mathrm{~g} \mathrm{~N}^{-1}\left(242.6 \mathrm{~g} \mathrm{~N} \mathrm{~m}^{-2}\right)$. Means within the same sampling date following with $*$, **, and $* * *$ are significantly different at $P<0.05,<0.01$, and $<0.001$, respectively. 

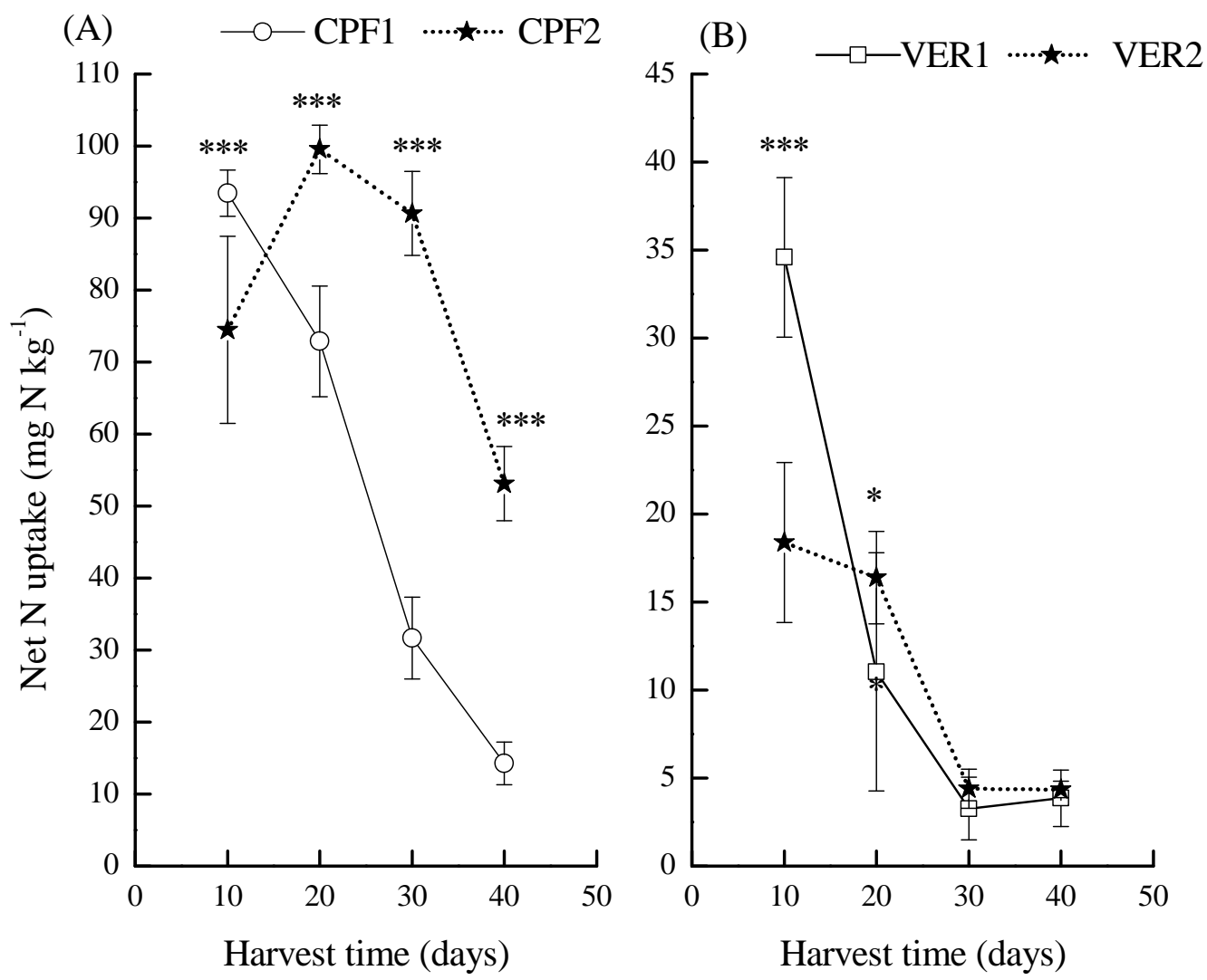

Fig.6.4. Effect of compost (A) and vermicompost (B) application rates on ryegrass net $\mathrm{N}$ uptake. $\mathrm{X}$-axis refers to the different harvests at different days after seedlings emergence. CPF1 and VER1: compost and vermicompost corresponding to $4 \mathrm{~g} \mathrm{~N}$ pot $^{-1}\left(121.3 \mathrm{~g} \mathrm{~N} \mathrm{~m}^{-2}\right)$; CPF2 and VER2: corresponding to $8 \mathrm{~g} \mathrm{~N}^{-1}\left(242.6 \mathrm{~g} \mathrm{~N} \mathrm{~m}^{-2}\right)$. Means within the same sampling date following with $*$, **, and $* * *$ are significantly different at $P<0.05,<0.01$, and $<0.001$, respectively.

\subsubsection{Crop cumulative biomass and net $N$ uptake}

Cumulative biomass yield was calculated with sum of the harvest at each date to the subsequent one. For pots amended with compost, the cumulative biomass was significantly higher $(P<0.05)$ across all harvests except for the harvest at 60 and 70 days and also for the 70 and 80 days because biomass and $\mathrm{N}$ content of both rates were not significantly different.

For the individual comparisons of compost rates, cumulative biomass yield in pots amended with compost corresponding to $4 \mathrm{~g} \mathrm{~N}$ pot $^{-1}$ was gradually and significantly ( $P$ $<0.01$ ) increased with time up to harvest at 60 days. 
The last two harvests did not add significant $(P>0.05)$ differences to the cumulative biomass. Regarding cumulative biomass from pots amended with compost corresponding to $8 \mathrm{~g} \mathrm{~N}$ pot $^{-1}$, values were gradually and significantly $(P<0.0001)$ increased across all harvests except for the last two harvests (Fig. 6.5A).

Concerning pots amended with vermicompost, for both rates, VER1 and VER2 (corresponding to 4 and $8 \mathrm{~g} \mathrm{~N}$ pot $^{-1}$, respectively), the addition of successive harvest biomass significantly $(P<0.05)$ increased with time. However, at each harvest date, the difference between the two rates were not significantly $(P>0.05)$. The only significant difference was only observed for the first harvest, where pots amended with materials corresponding to $4 \mathrm{~g} \mathrm{~N}$ pot $^{-1}$ had significantly higher biomass $(P<0.05)$ (Fig. 6.5B).

For pots amended with compost, positive response concerning plant growth with time that resulted in highly significant $(P<0.0001)$ differences in cumulative biomass, The differences between the two application rates were highly significant $(P<0.0001)$ at 40 days up to the end of experiment while the first three harvests were significantly different (Fig. 6.5B). 

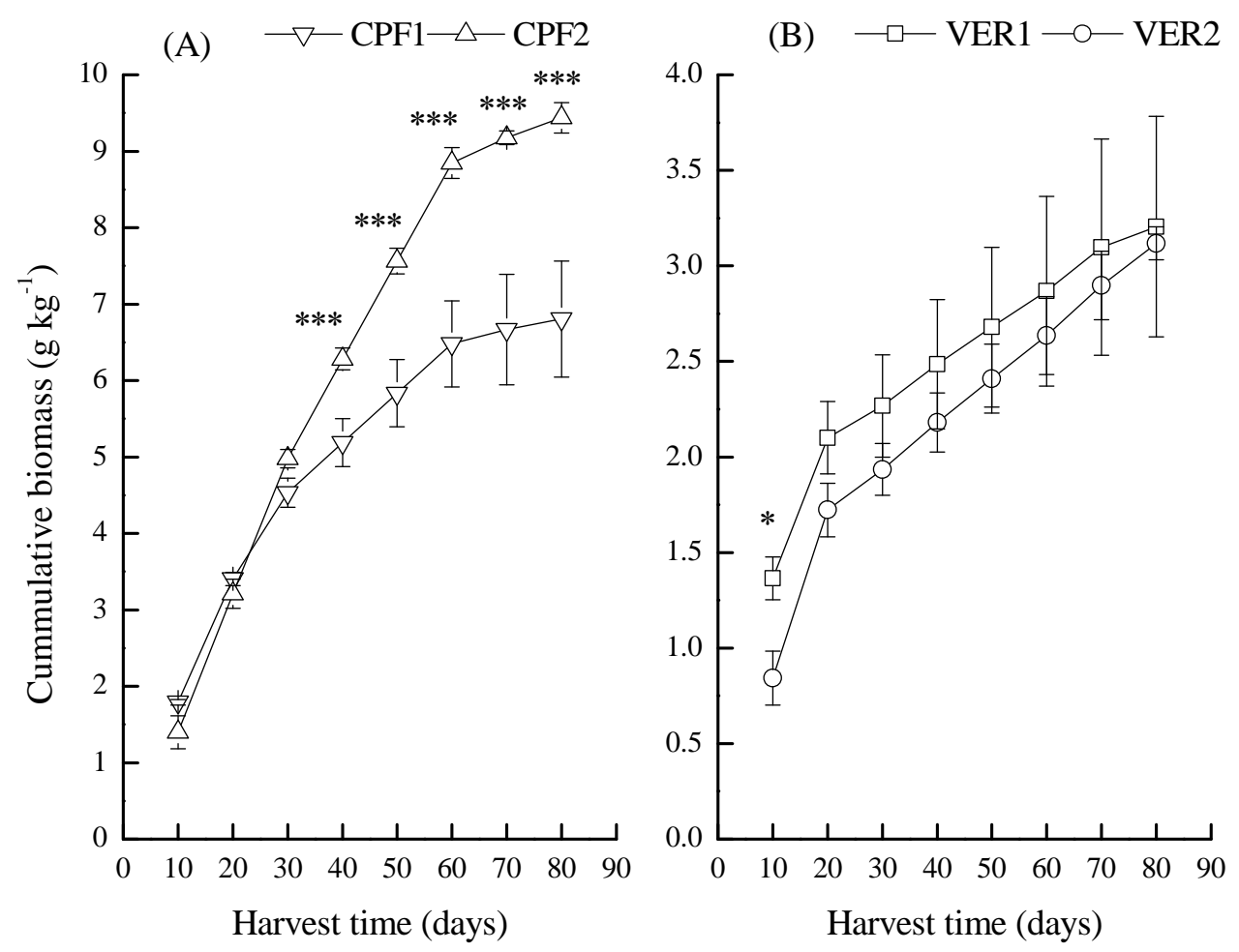

Fig 6.5. Effect of compost (A) and vermicompost (B) application rates on cumulative biomass. CPF1 and VER1: compost and vermicompost corresponding to $4 \mathrm{~g} \mathrm{~N} \operatorname{pot}^{-1}\left(121.3 \mathrm{~g} \mathrm{~N} \mathrm{~m}^{-2}\right)$; CPF2 and VER2: corresponding to $8 \mathrm{~g} \mathrm{~N}^{-1} \operatorname{pot}^{-1}\left(242.6 \mathrm{~g} \mathrm{~N} \mathrm{~m}^{-2}\right)$. Means within the same sampling date following with $*, * *$, and $* * *$ are significantly different at $P<0.05,<0.01$, and $<0.001$, respectively. 
Followed the same way in cumulative biomass, the cumulative nitrogen uptake was calculated with sum of the $\mathrm{N}$ content at each harvest to the subsequent one. For pots amended with compost, the cumulative $\mathrm{N}$ uptake was significantly higher across all harvests except for the first one because biomass and $\mathrm{N}$ content of both rates were not significantly different.

For the individual comparisons of compost rates, cumulative $\mathrm{N}$ uptake in pots amended with compost corresponding to $4 \mathrm{~g} \mathrm{~N}$ pot $^{-1}$ was gradually increased with time.

The cumulative $\mathrm{N}$ uptake significantly $(P<0.001)$ increased at 20 and 30 days, remained relatively constant at 40 and 50 days, significantly $(P<0.001)$ decreased at 60 days but relatively increased at 70 days, and remained with no significant change towards the end of the experiment period. Regarding cumulative $\mathrm{N}$ uptake in pots amended with compost corresponding to $8 \mathrm{~g} \mathrm{~N}^{-1}$, values were gradually and significantly $(P<0.0001)$ increased across all harvests except for the last three harvests where no significant change took place (Fig. 6.5A). Generally, the cumulative $\mathrm{N}$ uptake was significantly higher $(P$ $<0.0001)$ in the pots amended with compost corresponding to $8 \mathrm{~g} \mathrm{~N} \mathrm{pot}^{-1}(\mathrm{CPF} 2)$ compared to the lower rate (CPF1) except for the first harvest dates (Fig. 6.6A).

Regarding pots amended with vermicompost, for both rates (VER1 \& VER2) corresponding to 4 and $8 \mathrm{~g} \mathrm{~N}^{-1}{ }^{-1}$, respectively, addition of successive $\mathrm{N}$ uptake significantly $(P<0.05)$ increased the cumulative $\mathrm{N}$ uptake with time. However, at each harvest date, the difference between the two rates were not significantly $(P>0.05)$. The only significant differences was only observed for the first harvest, where pots amended with materials corresponding to $8 \mathrm{~g} \mathrm{~N}$ pot $^{-1}$ (VER2) had significant high cumulative $\mathrm{N}$ uptake $(P<0.05)$ (Fig. 6.6B).

The pattern of the cumulative $\mathrm{N}$ uptake followed the same pattern of the cumulative biomass. Pots amended with compost, positively responded to the application rates across all harvests. Concerning the vermicompost amended pots, the cumulative $\mathrm{N}$ uptake followed the same pattern with no statistical differences between the application rates except for the last date (10 days). However, both compost and vermicompost, ryegrass accumulated $\mathrm{N}$ uptake increased with rate applied (Fig. 6.6A \& B). The high differences 
observed between the compost and vermicompost were due to the addition of farm yard manure during the initiation of the experiment.

(A)

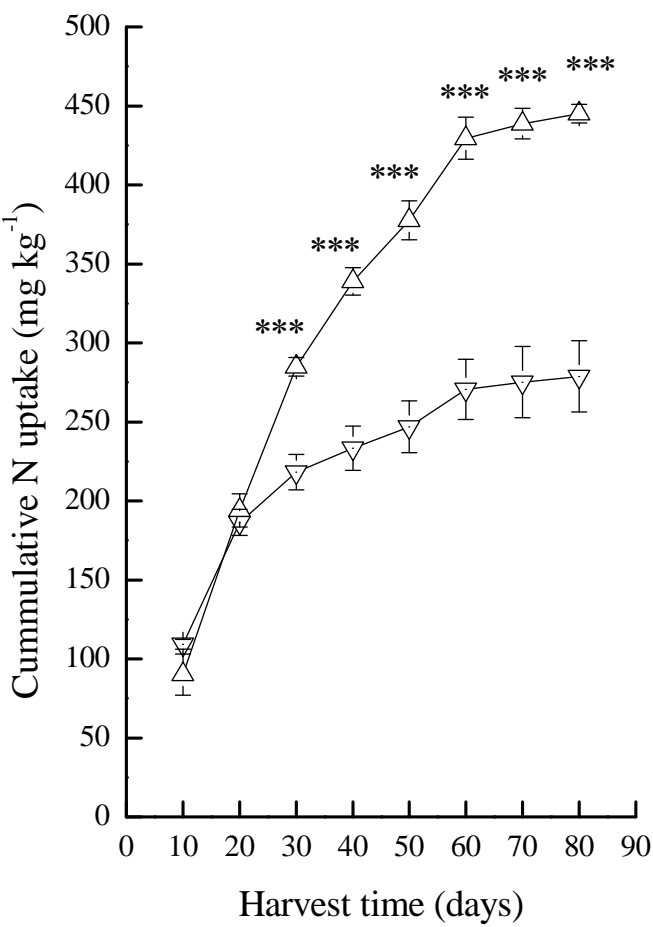

(B) $\square-$ VER1 — $—$ VER2

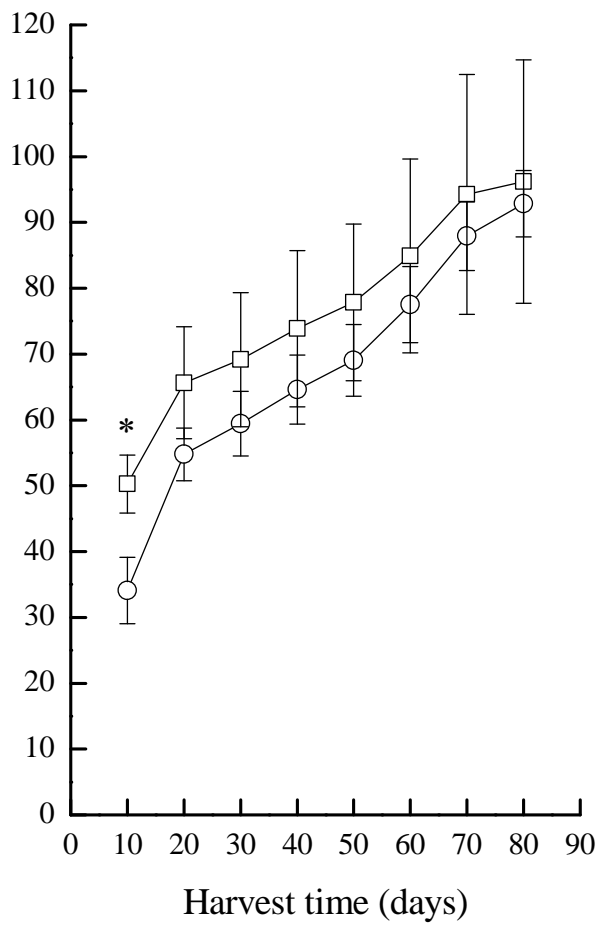

Fig 6.6. Effect of compost (A) and vermicompost (B) application rates on cumulative nitrogen uptake. CPF1 and VER1: compost and vermicompost corresponding to $4 \mathrm{~g} \mathrm{~N}^{-1}\left(121.3 \mathrm{~g} \mathrm{~N} \mathrm{~m}^{-}\right.$ ${ }^{2}$ ); CPF2 and VER2: corresponding to $8 \mathrm{~g} \mathrm{~N}$ pot $^{-1}\left(242.6 \mathrm{~g} \mathrm{~N} \mathrm{~m}^{-2}\right)$. Means within the same sampling date following with $* * *$, and $* * *$ are significantly different at $P<0.05,<0.01$, and $<0.001$, respectively.

\subsubsection{Crop phosphorus}

Pots amended with compost or vermicompost did not show statistical differences between applied rates. Based on the average values, no differences were observed between compost and vermicompost application rates corresponding to $8 \mathrm{~g} \mathrm{~N}_{\text {pot }}{ }^{-1}$ (CPF2 \& VER2).

For individual comparisons of ryegrass $\mathrm{P}$ content, the pattern of $\mathrm{P}$ uptake in pots amended with compost corresponding to $4 \mathrm{~g} \mathrm{~N} \operatorname{pot}^{-1}$ was inconsistent. The $\mathrm{P}$ uptake remained relatively constant at the first two harvests (10 and 20 days), significantly ( $P$ 
$<0,001)$ increased at 30 days, then declined at 50 days, relatively increased and further decreased at 70 days (Fig. 6.7A).

The trend of the compost rate corresponding to $4 \mathrm{~g} \mathrm{~N} \mathrm{pot}^{-1}$ (CPF1) was typically followed in $\mathrm{P}$ uptake of ryegrass sown in pot amended with compost corresponding to $8 \mathrm{~g} \mathrm{~N} \mathrm{pot}^{-1}$ (CPF2) (Fig. 6.7A). The average $\mathrm{P}$ uptake were 16 and $15 \mathrm{~g} \mathrm{~kg}^{-1}$ (1.6 \&1.5\%) for ryegrass sown on pots amended with compost corresponding to 4 and $8 \mathrm{~g} \mathrm{~N} \mathrm{pot}^{-1}$, respectively (CPF1 \& $\mathrm{CPF} 2$, respectively).

Phosphorus uptake of ryegrass sown on pots amended with vermicompost with both rates (VER1 \& VER2) increased significantly with time up to harvest at 30 days, declined at 50 days with statistical difference $(P<0.05)$, relatively increased at 60 days, but decreased again at 70 days. The only difference between the application rates was that the reduction at 70 days was significantly difference $(P<0.05)$ for the rate of application corresponding to $8 \mathrm{~g} \mathrm{~N} \mathrm{pot}^{-1}$ (VER2) (Fig. 6.7.B). For the different rates of application the average $\mathrm{P}$ uptake of ryegrass was 12 and $14 \mathrm{~g} \mathrm{~kg}^{-1}$ (1.2 \& 1.4\%) for vermicompost corresponding to 4 and $8 \mathrm{~g} \mathrm{~N}_{\text {pot }}{ }^{-1}$, respectively (VER1 \& VER2, respectively).

Based on these results, compost and vermicompost amended pots maintained $\mathrm{P}$ content above the sufficiency range 0.35-0.5\% (3.5-5 $\mathrm{g} \mathrm{kg}^{-1} \mathrm{DM}$ ) proposed by Bergmann (1992) for Lolium spp. The decline of plant growth below this range was reported by Rangeley (1989) where ryegrass growth began to decline when the content of total P in the leaves was less than $2.8 \mathrm{~g} \mathrm{P} \mathrm{kg}^{-1}$ dry weight. According to de Haan (1982), up to $15 \%$ of total P from compost would be available to plants from the first and second year of its application. 
Average ryegrass $\mathrm{P}$ uptake was not significantly $(P>0.05)$ affected by application rates. This was expected, because triple super phosphate (TSP) compensation dose was added to the vermicompost at sowing. This may interestingly indicates the ability of the compost $\mathrm{P}$ to be available to plant equally to the added mineral $\mathrm{P}$. This apparently could be because of manure $\mathrm{P}$ is composed of inorganic and organic $\mathrm{P}$ forms (Toor et al., 2006) after application to soil, these compounds undergo abiotic reactions which determine the availability of organic P to plant (Oberson et al., 2010). The presence of the plant stimulates an increment in the activity of enzymes specifically for $\mathrm{P}$ present in organic compounds (Ibrikci et al., 1994).

Cumulative $\mathrm{P}$ uptake as sum of the successive $\mathrm{P}$ uptake across harvests increased gradually with time (Fig 6.8A \& B). For the individual comparisons, cumulative P uptake of pots amended with compost corresponding to $4 \mathrm{~g} \mathrm{~N}$ pot $^{-1}$ (CPF1) increased gradually with time where the significant $(P<0.05)$ increase was 30 days (Fig. 8A). Regarding pots sown on pots amended with compost corresponding to $8 \mathrm{~g} \mathrm{~N}^{-1}$ (CPF2) the same pattern observed in the lower application rate was followed where the significant additions were at 30 and 50 days. The cumulative uptake of ryegrass sown on pots amended with compost corresponding to $8 \mathrm{~g} \mathrm{~N} \mathrm{pot}^{-1}$ (CPF2) was significantly higher at 30 days onwards (Fig. 6.8A). 

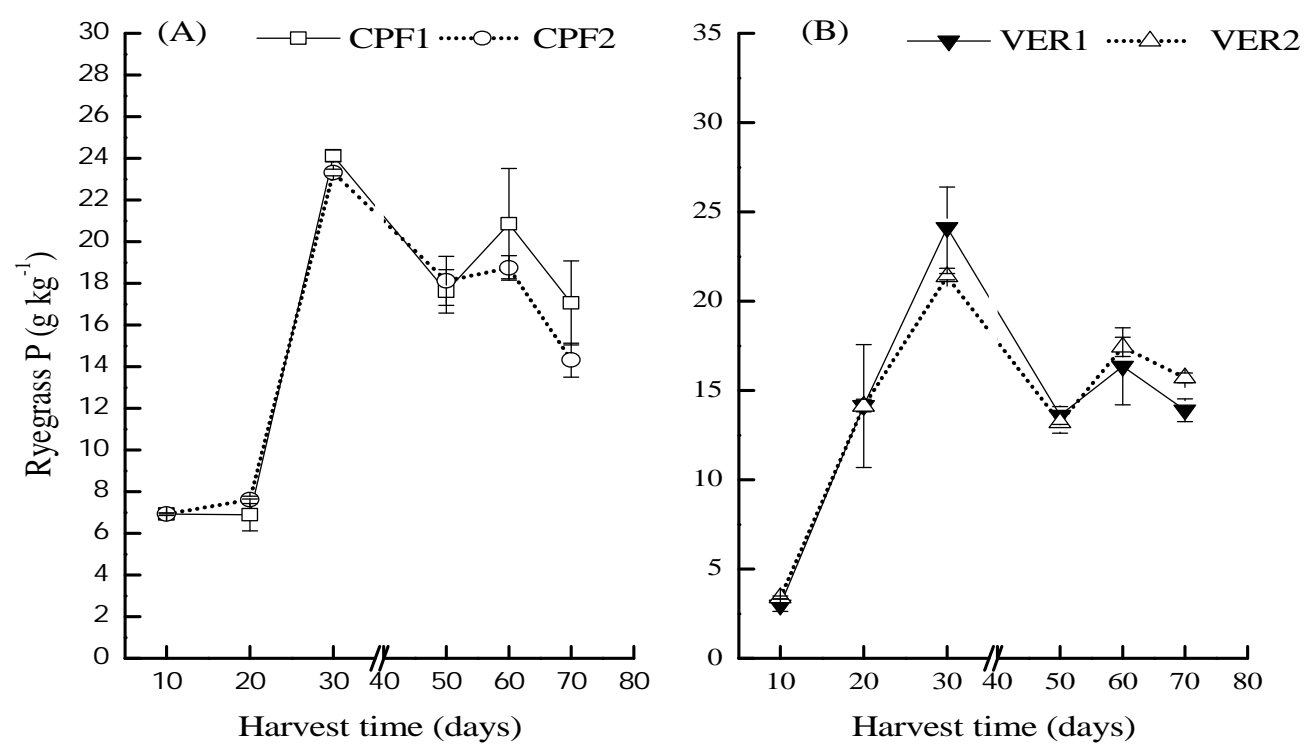

Fig.6.7. Effect of compost (A) and vermicompost (B) application rates on ryegrass P uptake. Xaxis refers to the different harvests at different days after seedlings emergence. VER1 and VER2: vermicompost corresponding to 4 and $8 \mathrm{~g} \mathrm{~N}_{\text {pot }}{ }^{-1}$ respectively; CPF1 (966.2 mg P) and CPF2 (1.2 $\mathrm{g} \mathrm{P})$ : compost corresponding to 4 and $8 \mathrm{~g} \mathrm{~N}_{\text {pot }}{ }^{-1}\left(121.3\right.$ and $\left.242.6 \mathrm{~g} \mathrm{~N} \mathrm{~m}^{-2}\right)$, respectively. Means within the same sampling date following with $* * *$, and $* * *$ are significantly different at $P$ $<0.05,<0.01$, and $<0.001$, respectively. The compost $\mathrm{P}$ was $1.2 \mathrm{~g} \mathrm{~kg}^{-1}$ while the vermicompost $\mathrm{P}$ was $41.7 \mathrm{mg} \mathrm{kg}^{-1}$ where TSP $(0.5 \mathrm{~g} \mathrm{P})$ was added.
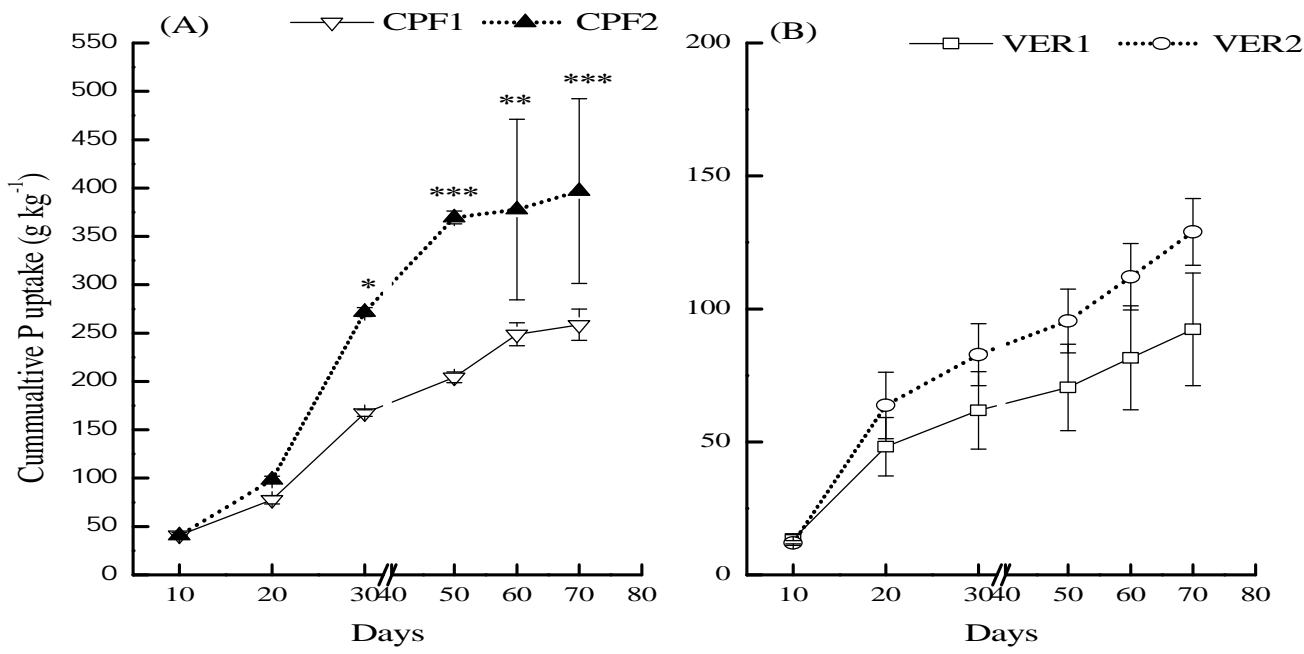

Fig.6.8. Effect of compost (A) and vermicompost (B) application rates on cumulative $\mathrm{P}$ uptake. VER1 and VER2: vermicompost corresponding to 4 and $8 \mathrm{~g} \mathrm{~N}^{-1}$ (121.3 and $242.6 \mathrm{~g} \mathrm{~N} \mathrm{~m}^{-2}$ ), respectively; CPF1 and CPF2: compost corresponding to 4 and $8 \mathrm{~g} \mathrm{~N}_{\text {pot }}{ }^{-1}$ respectively. Means within the same sampling date following with $* * *$, and $* * *$ are significantly different at $P$ $<0.05,<0.01$, and $<0.001$, respectively. The compost $\mathrm{P}$ was $1.2 \mathrm{~g} \mathrm{~kg}^{-1}$ while the vermicompost $\mathrm{P}$ was $41.7 \mathrm{mg} \mathrm{kg}^{-1}$ where TSP $(0.5 \mathrm{~g} \mathrm{P})$ was added. 
Differences in cumulative $\mathrm{P}$ uptake between compost and vermicompost amended pots were mainly due to the biomass yield, where the biomass yield was significantly higher especially during the first 6 harvests in the compost amended pots (Fig. 6.5 A \& B).

Biomass yield obtained from pots amended with compost and vermicompost was mainly a function of the amounts of $\mathrm{P}$ and $\mathrm{N}$ applied. Based on the data of biomass yield, total $\mathrm{N}$, and total P, multiple correlations were conducted in in order to differentiate between two effects.

For compost amended pots, biomass yield had highly positive correlation with $\mathrm{N}$ content ( $r=0.73 ; P<0.0001)$ but significant negative correlation with $\mathrm{P}$ content $(r=0.73 ; P$ $<0.05)$. Regarding vermicompost amended pots, no correlation between dry biomass and $\mathrm{N}$ content was found $(r=0.2 ; P=0.3)$ but a highly significant negative correlation was observed with $\mathrm{P}$ content $(r=-0.64 ; P<0.0001)$ (Table 6.3).

Total $\mathrm{N}$ was able to explain $>70 \%$ of the variation in biomass of ryegrass sown on the compost amended pots while P explained only $31 \%$ of the variation in biomass. For vermicompost amended pots, total $\mathrm{N}$ explained $20 \%$ only of the variation in biomass while P content $64 \%$ of the variation (Table 6.3). Hence, both nutrients contribute to the crop growth (Calderini et al., 1995; Mengel \& Kirkby, 1982).

The low $\mathrm{N}$ content in ryegrass, below the critical level of $30 \mathrm{mg} \mathrm{N} \mathrm{g}^{-1}$ dry matter proposed by Bergmann (1992) for Lolium spp., in most of the experiment period in vermicompost amended pots may indicate that, increase in biomass yield can be attributed to the effect of $\mathrm{P}$ because $\mathrm{P}$ content was above the critical level of $3.5 \mathrm{mg} \mathrm{P} \mathrm{g}^{-1}$ dry matter proposed by Bergmann (1992) for ryegrass; plants were then able to increase their aerial biomass so that plants with larger yields also had significantly larger total $\mathrm{P}$ (Bidegain et al., 2000).

There appeared to be a complementary relationship between $\mathrm{N}$ and $\mathrm{P}$ (Harrington et al., 2001). Based on our result, compost and vermicompost applied rates supplied ryegrass with the available $\mathrm{N}$ and $\mathrm{P}$ especially during the first 20 days, but at the end of the experiment the $\mathrm{N}$ content was low (Cegarra et al., 1996). 
Table 6.3. Correlations between growth parameters $(\mathrm{N}=48)$

\begin{tabular}{|c|c|c|c|}
\hline \multicolumn{4}{|l|}{ Compost } \\
\hline & Biomass yield & Total $\mathrm{N}$ & Total P \\
\hline $\begin{array}{l}\text { Biomass yield } \\
\text { Total } \mathbf{N} \\
\text { Total P }\end{array}$ & 1.00 & $\begin{array}{l}0.73 * * * \\
1.00\end{array}$ & $\begin{array}{l}-0.31 * \\
-0.60 * * * \\
1.00\end{array}$ \\
\hline \multicolumn{4}{|l|}{ Vermicompost } \\
\hline $\begin{array}{l}\text { Biomass yield } \\
\text { Total } \mathbf{N} \\
\text { Total } P\end{array}$ & 1.00 & $\begin{array}{l}0.2 \mathrm{~ns} \\
1.00\end{array}$ & $\begin{array}{l}-0.64 * * * \\
-0.36 * * \\
1.00\end{array}$ \\
\hline
\end{tabular}

Ryegrass total $\mathrm{N}(\%)$; total $\mathrm{P}\left(\mathrm{g} \mathrm{kg}^{-1}\right)$ and Biomass yield $\left(\mathrm{g} \mathrm{pot}^{-1}\right)$.

Statistical significant at: ns; non-significant; ${ }^{*} P \leq 0.05$, and $* * P \leq 0.01 ; * * * P \leq 0.001$, respectively.

Results of this work were in accordance with some coworkers, for instance, Soumaré, (2003) concluded that compost application rates had significant effect on plant $\mathrm{N}$ and $\mathrm{P}$ contents and compost application appeared to be a good supplier of nutrients. Bidegain et al. (2000) reported that, phosphorus deficiency in ryegrass was maintained with the addition of humic substances from decomposed poplar sawdust. The results of this work are in contradiction with that obtained by others; where ryegrass produced more dry matter and took up more $\mathrm{P}$ when fertilized with mineral $\mathrm{P}$ than with manure P (Cornish, 2009; Løes \& Øgaard, 2001; Oberson et al., 2010). 


\subsubsection{Nitrogen mineralization}

Accumulation of $\mathrm{NH}_{4}-\mathrm{N}$ from amended soils is illustrated in Figure 6.9. With the exception of the control, after the first week there was a period of immediate release of $\mathrm{NH}_{4}-\mathrm{N}$.

In all amended soil and throughout the period of the incubation, values of cumulative $\mathrm{NH}_{4}-\mathrm{N}$ from amended soils were clustering around the control except for soils amended with compost corresponding to $8 \mathrm{~g} \mathrm{~N} \mathrm{pot}^{-1}$ (CPF2) at week 3, 7, and 14 of incubation. The same pattern was observed for soils amended with vermicompost corresponding to $8 \mathrm{~g} \mathrm{~N}$ pot $^{-1}$ (VER2) at week 21. Maximum and minimum values of $\mathrm{NH}_{4}-\mathrm{N}$ varied between the compost and vermicompost application rates. Accordingly, they were found to range from 0.42 to $5.41,0.83$ to $7.91,2.39$ to 4.6 , and 2.2 to 23.6 $\mathrm{mg} \mathrm{NH}_{4}-\mathrm{N} \mathrm{kg}^{-1}$ for the vermicompost corresponding to $4 \mathrm{~g} \mathrm{~N}^{-1}$ (VER1), vermicompost corresponding to $8 \mathrm{~g} \mathrm{~N}$ pot $^{-1}$ (VER2), compost corresponding to $4 \mathrm{~g} \mathrm{~N}$ $\operatorname{pot}^{-1}$ (CPF1), and compost corresponding to $8 \mathrm{~g} \mathrm{~N} \mathrm{pot}^{-1}$ (CPF2), respectively. After 28 weeks, the contents of $\mathrm{NH}_{4}-\mathrm{N}$ from the amended soils were similar and very close to the control. They were 5.41, 3.06, 3.64, and $3.74 \mathrm{mg} \mathrm{NH}_{4}-\mathrm{N} \mathrm{kg}^{-1}$ for VER1, VER2, CPF1, and CPF2, respectively.

Net mineralization of $\mathrm{NO}_{3}-\mathrm{N}$ from compost and vermicompost with the exception of week 14, (net $\mathrm{N}$ immobilization) showed clear patterns throughout the incubation period (Fig. 6.10). Nitrate-N was consistently released from CPF2 while CPF1 was found to give the lowest net $\mathrm{NO}_{3}-\mathrm{N}$ mineralization (ranging from 5 to $23 \mathrm{mg} \mathrm{NO}_{3}-\mathrm{N}$ $\left.\mathrm{kg}^{-1}\right)$. The differences of net $\mathrm{N}$ mineralization between compost applications rates (CPF1 \& CPF2) were significant starting from week 14 onwards $(P<0.05)$ (Fig. $6.10)$.

The greatest net $\mathrm{NO}_{3}-\mathrm{N}$ mineralization during the entire incubation period was recorded in the VER2 (12 - $\left.43 \mathrm{mg} \mathrm{NO} \mathrm{NO} \mathrm{kg}^{-1}\right)$. The differences between vermicompost application rates (VER1 \& VER2) were significant $(P<0.05)$ at week 3,7 , and 14 while remained with no significant difference within the other incubation period. Generally, the release of $\mathrm{NO}_{3}-\mathrm{N}$ was in order of VER2 (12-43 mg NO $\mathrm{NO}_{3}-\mathrm{N} \mathrm{kg}^{-1}$ ) $>\mathrm{CPF} 2\left(2.0-41 \mathrm{mg} \mathrm{NO}_{3}-\mathrm{N} \mathrm{kg}^{-1}\right)>\operatorname{VER} 1\left(8-39 \mathrm{mg} \mathrm{NO}_{3}-\mathrm{N} \mathrm{kg}^{-1}\right)>\mathrm{CPF} 1(4-23 \mathrm{mg}$ $\mathrm{NO}_{3}-\mathrm{N} \mathrm{kg}^{-1}$ ). 
Accumulated total mineral $\mathrm{N}$ under soils amended with compost and vermicompost is illustrated in Figure 11. The pattern of the total mineral $\mathrm{N}$ followed the same trend observed in the $\mathrm{NH}_{4}-\mathrm{N}$ net release during the first 7 weeks and the pattern of $\mathrm{NO}_{3}-\mathrm{N}$ release thereafter.

With the exception of CPF1, after the first week there was a period of increase of total mineral $\mathrm{N}$ throughout the experiment period. At week 14 all amended soils showed $\mathrm{N}$ immobilization except CPF2. Vermicompost corresponding to $4 \mathrm{~g} \mathrm{~N}^{-1}$ declined sharply at this date. Throughout the period of the incubation, values of total mineral $\mathrm{N}$ from CPF1 and VER1 were clustering around the control except for week 21 and 28 for CPF1 and week 14, 21, and 28 for VER1. Total mineral $\mathrm{N}$ of the CPF2 and VER2 were significantly $(P<0.001)$ higher throughout the experiment period with the exception of the first week.

Maximum and minimum values of total mineral $\mathrm{N}$ varied between the compost and vermicompost application rates. Accordingly, they were found to range from 9.41 to 44.0, 13.2 to $51.0,7.2$ to 27.4 , and 4.2 to $46.0 \mathrm{mg} \mathrm{N} \mathrm{kg}^{-1}$ for the VER1, VER2, CPF1, $\mathrm{CPF} 2$, respectively.

Net $\mathrm{N}$ mineralization at the end of the incubation period was significantly $(P<0.001)$ different between compost and vermicompost and their application rates (Fig. 6.12). Soils amended with VER1, VER2, and CPF2 resulted in net $\mathrm{N}$ mineralization approximately double that that reported for soils amended with CPF1. Net $\mathrm{N}$ mineralization was in order of VER2 $\geq \mathrm{CPF} 2 \geq \mathrm{VER} 1>\mathrm{CPF} 1$.

The immediate release of $\mathrm{NH}_{4}-\mathrm{N}$ observed in this study showed that there was a rapid phase of decomposition after mixing the compost and vermicompost. Khalil et al. (2005) observed that great flux of carbon dioxide $\left(\mathrm{CO}_{2}\right)$ after 2 days from incubation of crop residue and chicken manure. Similarly, Abbasi et al.(2007) observed a rapid initial (10 - 20 days) release phase from poultry, sheep and chicken manure. This shows that application of composted and vermicomposted cotton residues for period longer than 3 weeks before sowing subsequent crops may subject $\mathrm{N}$ to losses due to volatilization. In this study, compost and vermicompost showed that there was no further release of $\mathrm{NH}_{4}-\mathrm{N}$ after 28 weeks. 
The higher content of $\mathrm{NH}_{4}-\mathrm{N}$ observed during the first 14 weeks in the compost was due to the addition of farm yard manure (FYM) added during the setup of the experiment. The $\mathrm{NH}_{4}-\mathrm{N}$ values obtained at week 21 onwards where relative higher values were recorded for the vermicompost may be attributed to the grazing capacity of the microbes in the vermicompost. The fluctuations of $\mathrm{NH}_{4}-\mathrm{N}$ release during the incubation period suggest loss of $\mathrm{NH}_{4}-\mathrm{N}$ from the amended soil by $\mathrm{NH}_{3}$ volatilization or could be explained by an event of rapid nitrification combined with denitrification (Yousif \& Abdalla, 2009).

In this study, $\mathrm{NO}_{3}-\mathrm{N}$ was dominant form of inorganic $\mathrm{N}$, which did not agree with that reported by Maithani et al. (1998), who found that the $\mathrm{NH}_{4}-\mathrm{N}$ the dominant form of inorganic $\mathrm{N}$. This could be due slightly alkaline and alkaline nature of the compost and vermicompost, respectively $(\geq 7.0)$ which may have increased the growth and activity of autotrophic nitrifiers (Chao et al., 1993).

Earthworms had a great impact on nitrogen transformations and hence enhancing nitrogen mineralization. Earthworm activity usually enhances microbial biomass and diversity in organic wastes to levels even greater than those in thermophilic composts (Edwards, 1998a; Edwards et al., 2010; Yardim et al., 2006). The stimulated microorganisms in the vermicompost increased the released more $\mathrm{NO}_{3}-\mathrm{N}$ during the first weeks, and consequently the total mineral $\mathrm{N}$. The dominance of $\mathrm{NO}_{3}-\mathrm{N}$ form was in agreement with the results reported by Atiyeh et al. (2000a) and Hand et al.(1988) who suggested that earthworms produce conditions that favor nitrification, resulting in the rapid conversion of $\mathrm{NH}_{4}-\mathrm{N}$ into $\mathrm{NO}_{3}-\mathrm{N}$ and consequently increases the $\mathrm{NO}_{3}-\mathrm{N}$ content of the substrate.

The differences in $\mathrm{N}$ mineralization among compost and vermicompost application rates were clear especially for the compost rates. Amending soils with organic wastes is sometimes followed by an extended period where $\mathrm{N}$ immobilization limits $\mathrm{N}$ availability (Eneji et al., 2002). Other workers have found that laboratory incubations of amended soils lasting for weeks may result in negative $\mathrm{N}$ mineralization values (Hadas \& Portnoy, 1994), while longer incubation periods resulted in positive values, waiting for more than 14 weeks for positive $\mathrm{N}$ mineralization would miss the period of high $\mathrm{N}$ demand of most crops if the soils are planted soon after amending the soils (Calderon et al., 2004). 


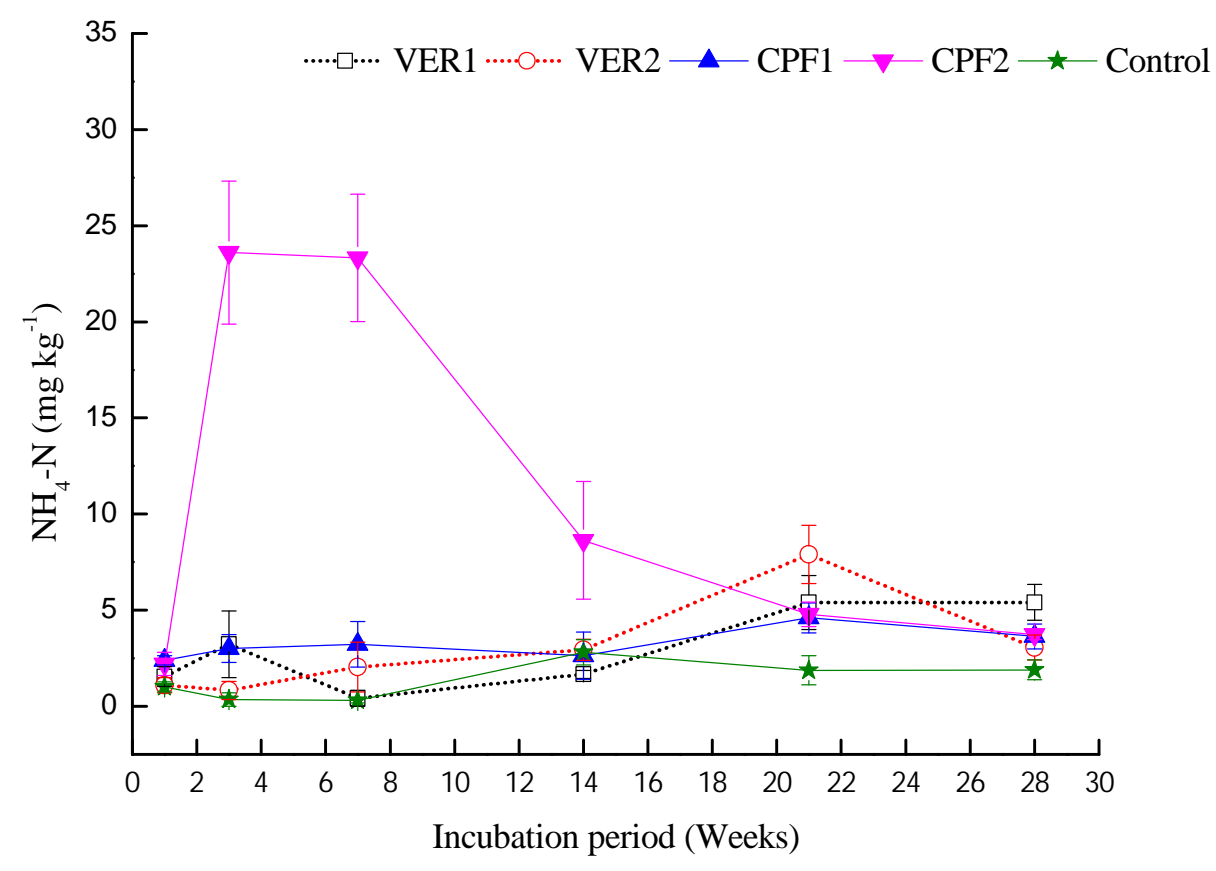

Fig.6.9. Accumulated $\mathrm{NH}_{4}-\mathrm{N}$ during incubation of compost and vermicompost. VER1 and VER2: vermicompost corresponding to 4 and $8 \mathrm{~g} \mathrm{~N} \mathrm{pot}^{-1}\left(121.3\right.$ and $\left.242.6 \mathrm{~g} \mathrm{~N} \mathrm{~m}^{-2}\right)$, respectively; CPF1 and CPF2: compost corresponding to 4 and $8 \mathrm{~g} \mathrm{~N} \mathrm{pot}^{-1}$, respectively. (vertical bars are standard errors).

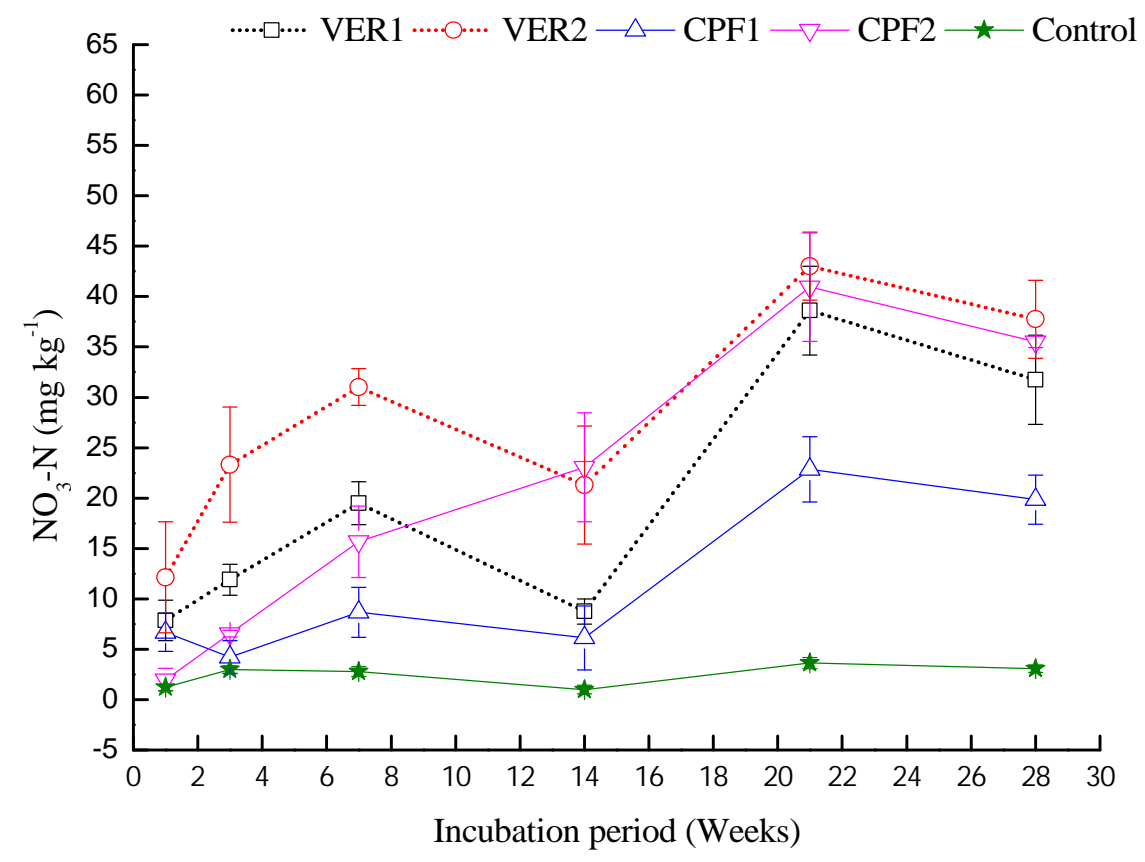

Fig.6.10. Accumulated $\mathrm{NO}_{3}-\mathrm{N}$ during incubation of compost and vermicompost. VER1 and VER2: vermicompost corresponding to 4 and $8 \mathrm{~g} \mathrm{~N}_{\text {pot }}{ }^{-1}$ respectively; CPF1 and CPF2: compost corresponding to 4 and $8 \mathrm{~g} \mathrm{~N}_{\text {pot }}{ }^{-1}$ (121.3 and $242.6 \mathrm{~g} \mathrm{~N} \mathrm{~m}^{-2}$ ), respectively. (vertical bars are standard errors). 


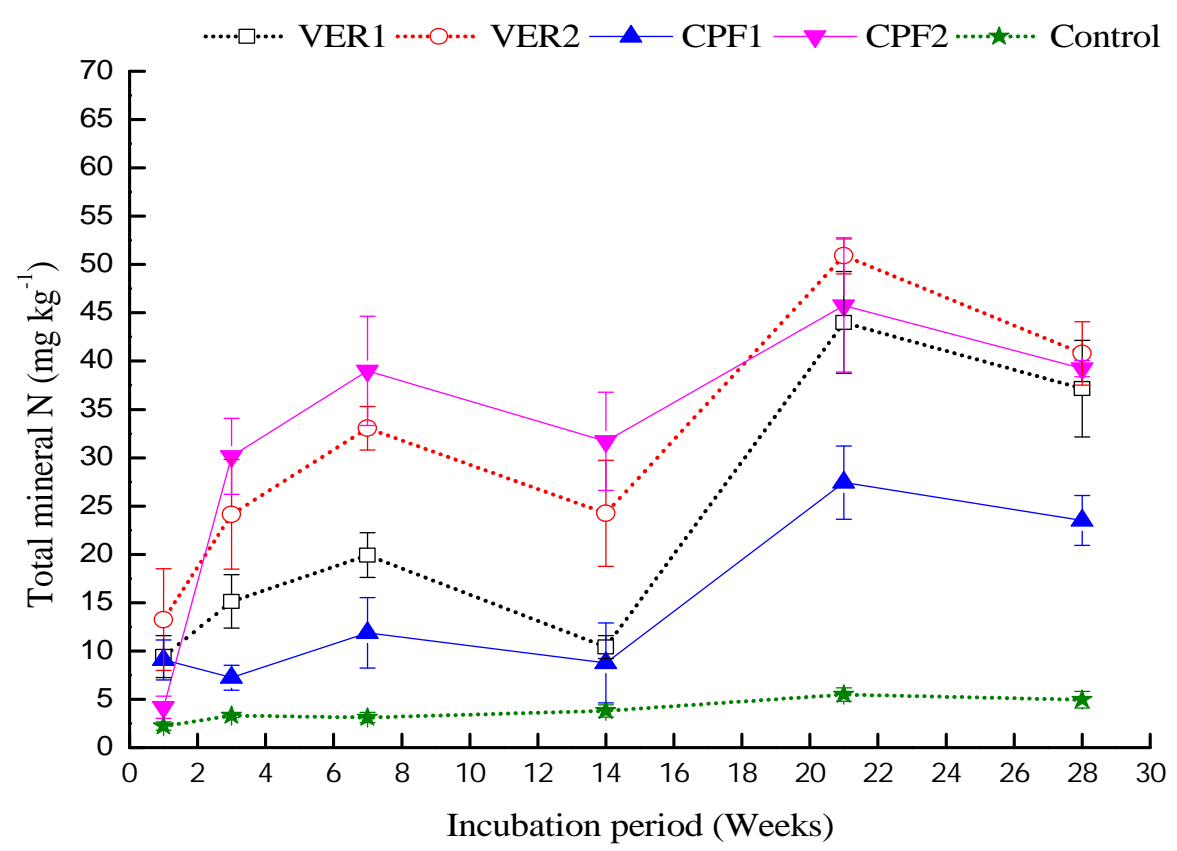

Fig.6.11. Total mineral $\mathrm{N}$ resulted from incubated compost and vermicompost. VER1 and VER2: vermicompost corresponding to 4 and $8 \mathrm{~g} \mathrm{~N} \mathrm{pot}^{-1}\left(121.3\right.$ and $242.6 \mathrm{~g} \mathrm{~N} \mathrm{~m}^{-2}$ ), respectively; CPF1 and CPF2: compost corresponding to 4 and $8 \mathrm{~g} \mathrm{~N}_{\text {pot }}{ }^{-1}$, respectively. (vertical bars are standard errors).

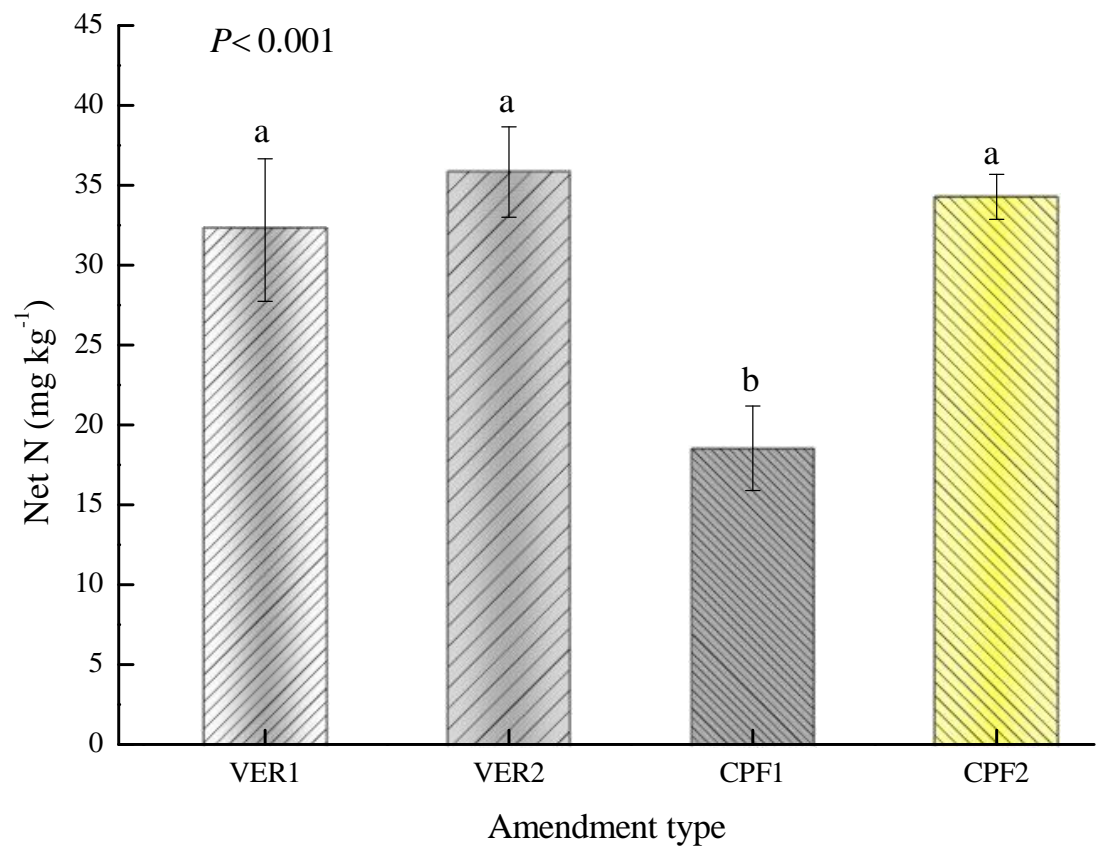

Fig.6.12. Net $\mathrm{N}$ mineralization ( $\mathrm{mg} \mathrm{kg}^{-1}$ ) of compost and vermicompost during 28 weeks of incubation. VER1 and VER2: vermicompost corresponding to 4 and $8 \mathrm{~g} \mathrm{~N}_{\text {pot }}{ }^{-1}$ respectively; CPF1 and CPF2: compost corresponding to 4 and $8 \mathrm{~g} \mathrm{~N}^{-1}$ (121.3 and $242.6 \mathrm{~g} \mathrm{~N} \mathrm{~m}^{-2}$ ), respectively. Columns with the same letters are not significantly different using least significant difference (LSD). (vertical bars are standard errors). 
An accepted level of maturity of organic wastes, which implies potential for the development of beneficial effects when they are used for plant growth, can be better determined by plant growth bioassays (Chen \& Inbar, 1993). In our experiment compost and vermicompost enhanced ryegrass $\mathrm{N}$ uptake; their application rates resulted in a positive relation between biomass production and $\mathrm{N}$ content compared to the control. The plant growth enhancement could be due to the more favorable physiochemical characteristics and higher content of mineral $\mathrm{N}$ that is readily available for plant uptake compared to the unamended soils. Studies of N uptake of ryegrass have shown that it may be acquired from either the $\mathrm{NH}_{4}-\mathrm{N}_{\text {or }} \mathrm{NO}_{3}-\mathrm{N}$ pools during initial growth and subsequent growth periods (Griffith \& Streeter, 1994; HóchJensen et al., 1997; Louahlia et al., 2000).

Generally, data on $\mathrm{N}$ mineralization or immobilization can readily be used in modeling studies to evaluate the long term effects of composted and vermicomposted cotton residues on soil fertility. 


\subsection{Conclusions}

In conclusion, in this study compost and vermicompost had positive effects on $\mathrm{N}$ availability and ryegrass growth in terms of enhanced plant growth and mineralized $\mathrm{N}$ compared to the control. The scale of differences in crop yield between application rates indicated that differences in $\mathrm{N}$ and $\mathrm{P}$ supply were probably the main factor affecting ryegrass production. However, generally the results showed that there was enhancement in plant growth and $\mathrm{N}$ uptake in ryegrass especially during the first weeks of the study period.

Additionally, results from the incubation experiment suggests that application of composted and vermicomposted cotton residues for period longer than 3 weeks before sowing subsequent crops may subject $\mathrm{N}$ to losses.

For future perspectives, there may be scope to maximize nutrient use and minimize potential losses by mixing different types of organic materials; for instance, combination of cotton residues with the readily available $\mathrm{N}$ from different wastes or mineral fertilizers may increase both crop yield and soil quality.

In summary:

- Attributes of the tested materials in providing $\mathrm{N}$ to ryegrass cannot perfectly be predicted using long term aerobic incubations tests.

- Ryegrass has shown low recovery of added $\mathrm{N}$ where the apparent $\mathrm{N}$ recovery values of both materials revealed that more than $80 \%$ was not taken up within the three months of the pot experiment. However, amended soils may retain significant part of the organic $\mathrm{N}$ which may slowly be released over time $(\mathrm{N}$ residual effects).

- Results from the mineralization incubations gave general indications of $\mathrm{N}$ availability for crops when these materials are intended to be used for crop fertilization.

- Further studies are necessary to characterize the behavior of cotton residues nutrients mineralization, particularly its microbial degradation and time required to supply sufficient amount of nutrients for crop growth. 


\subsection{References}

Abbasi, M. K., Hina, M., Khalique, A., \& Sumyya, R. K. (2007). Mineralization of three organic manures used as nitrogen source in a soil incubated under laboratory conditions. Communications in Soil Science and Plant Analysis, 38, 1691-1711.

Adam, H. S., \& Farbrother, G. H. (1975). Three Gezira Research Station techniques for the assessment of 'first water' requirements. Wad Medani, Sudan: Agricultural Research Corporation.

Aitken, M. N., Evans, B., \& Lewis, J. G. (1998). Effect of applying paper mill sludge to arable land on soil fertility and crop yields. Soil Use and Management, 14, 215-222.

Alexander, M. (1977). Mineralization of nitrogen In: M. Alexander (Ed.), Introduction to Soil Microbiology (2nd ed.). John Wilcy \& Sons New York.

Appel, T., \& Mengel, K. (1993). Nitrogen fractions in sandy soils in relation to plant nitrogen uptake and organic matter incorporation. Soil Biology and Biochemistry, 25, 685-691.

Atiyeh, R. M., Dominguez, J., Subler, S., \& Edwards, C. A. (2000). Changes in biochemical properties of cow manure during processing by earthworms (Eisenia andrei, Bouché) and the effects on seedling growth. Pedobiologia, 44, 709-724.

Bellamy, K. L., Chong, C., \& Cline, R. A. (1995). Paper sludge utilization in agriculture and container nursery culture. Journal of Environmental Quality, 24, 1074-1082.

Benton, J., Wolf, B., \& Mills, H. (1991). Plant analysis handbook. Micro-Macro publishing. Georgia, USA, 180-180.

Bergmann, W. (1992). Nutritional Disorders of Plants: Development, Visual and Analytical Diagnosis. Gustav Fischer Verlag.

Bidegain, R. A., Kaemmerer, M., Guiresse, M., Hafidi, M., Rey, F., Morard, P., \& Revel, J. C. (2000). Effects of humic substances from composted or chemically decomposed poplar sawdust on mineral nutrition of ryegrass. Journal of Agricultural Science, 134, 259-267.

Bremner, J. M. (1965). Nitrogen availability index In: C. A. Black, D. D. Evans, J. L. White, L. E. Ensmminger \& F. E. Clarke (Eds.), Methods of soil analysis (Vol. Agronomy 9, pp. 1324-1341). American Society: Madison, Wisconson. 
Cabrera, M. L., Kissel, D. E., \& Vigil, M. F. (2005). Nitrogen mineralization from organic residues: research opportunities. Journal of Environment Quality, 34, 75-79.

Calderini, D. F., Torres-León, S., \& Slafer, G. A. (1995). Consequences of wheat breeding on nitrogen and phosphorus yield, grain nitrogen and phosphorus concentration and associated traits. Annals of Botany, 76, 315-315.

Calderon, F. J., McCarty, G. W., Van Kessel, J. A. S., \& Reeves Iii, J. B. (2004). Carbon and nitrogen dynamics during incubation of manured soil. Soil Science Society of America Journal, 68, 1592-1599.

Cegarra, J., Paredes, C., Roig, A., Bernal, M. P., \& Garcia, D. (1996). Use of olive mill wastewater compost for crop production. International Biodeterioration \& Biodegradation, 38, 193-203.

Chadwick, D. R., John, F., Pain, B. F., Chambers, B. J., \& Williams, J. (2000). Plant uptake of nitrogen from the organic nitrogen fraction of animal manures: a laboratory experiment. The Journal of Agricultural Science, 134, 159-168.

Chao, W. L., Gan, K. D., \& Chao, C. C. (1993). Nitrification and nitrifying potential of tropical and subtropical soils. Biology and Fertility of Soils, 15, 87-90.

Chapman, H. D., \& Pratt, P. F. (1962). Methods of analysis for soils, plants and waters. Soil Science, 93, 68-68.

Chen, Y., \& Inbar, Y. (1993). Chemical and spectroscopical analysis of organic matter transformations during composting in relation to compost maturity. In: H. A. J. Hoitink \& H. M. Keener (Eds.), Science and Engineering of Composting: Design, Environmental, Microbiological and Utilization Aspects (pp. 622-644). Renaissance Publication: Worthington, $\mathrm{OH}$.

Cheng, H., Xu, W., Liu, J., Zhao, Q., He, Y., \& Chen, G. (2007). Application of composted sewage sludge (CSS) as a soil amendment for turfgrass growth. Ecological Engineering, 29, 96-104.

Constantinides, M., \& Fownes, J. H. (1994). Nitrogen mineralization from leaves and litter of tropical plants: relationship to nitrogen, lignin and soluble polyphenol concentrations. Soil Biology and Biochemistry, 26, 49-55.

Cordovil, C. M., Cabral, F., \& Coutinho, J. (2007). Potential mineralization of nitrogen from organic wastes to ryegrass and wheat crops. Bioresource Technology, 98, 32653268 . 
Cornish, P. S. (2009). Phosphorus management on extensive organic and low-input farms. Crop and Pasture Science, 60, 105-115.

Corrêa, R. S. (2004). Efficiency of five biosolids to supply nitrogen and phosphorus to ryegrass. Pesquisa Agropecuaria Brasileira, 39, 1133-1139.

Coutinho, J., Arrobas, M., \& Rodrigues, O. (1997). Effect of composted sewage sludge amendment on soil nitrogen and phosphorus availability. Communications in Soil Science and Plant Analysis, 28, 1845-1857.

Dar, G. H., \& Mishra, M. M. (1994). Influence of cadmium on carbon and nitrogen mineralization in sewage sludge amended soils. Environmental Pollution, 84, 285-290.

de Haan, A., \& Bodemvruchtbaarheid, I. v. (1982). Results of municipal waste compost research over more than fifty years at the Institute for Soil Fertility at Haren/Groningen, the Netherlands. Instituut voor Bodemvruchtbaarheid.

Dilz, K. (1988). Efficiency of uptake and utilization of fertilizer nitrogen by plants. In: D. S. Jenkinson \& K. A. Smith (Eds.), Nitrogen efficiency in agricultural soils (pp. 1-26). Elsevier Applied Science: London.

Douglas, J. T., Aitken, M. N., \& Smith, C. A. (2003). Effects of five non-agricultural organic wastes on soil composition, and on the yield and nitrogen recovery of Italian ryegrass. Soil Use and Management, 19, 135-138.

Ebertseder, T., \& Gutser, R. (2001, 22-23 November). Nutrition Potential of Biowaste Composts. Paper presented at the Applying Compost Benefits and Needs, Brussels. 117128.

Edwards, C. A. (1998). The use of earthworms in processing organic wastes into plant growth media and animal feed protein. In: C. A. Edwards (Ed.), Earthworm Ecology (pp. 327-354). CRC Press Boca Raton, Florida.

Edwards, C. A., Arancon, N. Q., Vasko-Bennett, M., Askar, A., \& Keeney, G. (2010). Effect of aqueous extracts from vermicomposts on attacks by cucumber beetles (Acalymna vittatum)(Fabr.) on cucumbers and tobacco hornworm (Manduca sexta) (L.) on tomatoes. Pedobiologia, 53, 141-148.

Eghball, B., Ginting, D., \& Gilley, J. E. (2004). Residual effects of manure and compost applications on corn production and soil properties. Agronomy Journal, 96, 442-447. 
Eghball, B., \& Power, J. F. (1999). Phosphorus-and nitrogen-based manure and compost applications: corn production and soil phosphorus. Soil Science Society of America Journal, 63, 895-901.

Eghball, B., Power, J. F., Gilley, J. E., \& Doran, J. W. (1997). Nutrient, carbon, and mass loss during composting of beef cattle feedlot manure. Journal of Environmental Quality, 26, 189-193.

Eneji, A. E., Honna, T., Yamamoto, S., Saito, T., \& Masuda, T. (2002). Nitrogen transformation in four Japanese soils following manure+ urea amendment. Communications in Soil Science and Plant Analysis, 33, 53-66.

Evers, G. W. (2002). Ryegrass-bermudagrass production and nutrient uptake when combining nitrogen fertilizer with broiler litter. Agronomy Journal, 94, 905-910.

Fox, R. H., Myers, R. J. K., \& Vallis, I. (1990). The nitrogen mineralization rate of legume residues in soil as influenced by their polyphenol, lignin, and nitrogen contents. Plant and Soil, 129, 251-259.

Frankenberger, W. T., \& Abdelmagid, H. M. (1985). Kinetic parameters of nitrogen mineralization rates of leguminous crops incorporated into soil. Plant and Soil, 87, 257271.

Gallardo-Lara, F., \& Nogales, R. (1987). Effect of the application of town refuse compost on the soil-plant system: A review. Biological Wastes, 19, 35-62.

Gaur, A. C., \& Singh, G. (1995). Recycling of rural and urban wastes through conventional and vermicomposting. In: H. L. S. Tandon (Ed.), Recycling of crop, Animal, Human and Industrial waste in Agriculture (pp. 31-49). Fertilizer Development and Consultation Organization: New Delhi.

Giller, K. E., \& Cadisch, G. (1997). Driven by nature: a sense of arrival or departure. In: G. Cadisch \& K. E. Giller (Eds.), Driven by Nature: Plant Litter Quality and Decomposition (pp. 393-399). CAB International: Wallingford.

Goudling, K. (2004). Pathways and losses of fertilizer nitrogen at different scales. In: A. R. Mosier, J. K. Syers \& J. R. Freney (Eds.), Agriculture and the Nitrogen Cycle: Assessing the Impacts of Fertilizer Use on Food Production and the Environment (SCOPE) (pp. 209-219). Island Press: Covelo, California, USA. 
Griffith, S. M., \& Streeter, D. J. (1994). Nitrate and ammonium nutrition in ryegrass: changes in growth and chemical composition under hydroponic conditions. Journal of Plant Nutrition, 17, 71-81.

Hadas, A., Kautsky, L., Goek, M., \& Erman Kara, E. (2004). Rates of decomposition of plant residues and available nitrogen in soil, related to residue composition through simulation of carbon and nitrogen turnover. Soil Biology and Biochemistry, 36, 255-266.

Hadas, A., \& Portnoy, R. (1994). Nitrogen and carbon mineralization rates of composted manures incubated in soil. Journal of Environmental Quality, 23, 1184-1189.

Hand, P., Hayes, W. A., Frankland, J. C., \& Satchell, J. E. (1988). Vermicomposting of cow slurry. Pedobiologia, 31, 199-209.

Harmsen, G. W., \& Van Schreven, D. A. (1955). Mineralization of organic nitrogen in soil. Advances in Agronomy, 7, 299-398.

Harrington, R. A., Fownes, J. H., \& Vitousek, P. M. (2001). Production and resource use efficiencies in $\mathrm{N}$-and P-limited tropical forests: a comparison of responses to long-term fertilization. Ecosystems, 4, 646-657.

Hassen, A., Jedidi, N., Cherif, M., M'Hiri, A., Boudabous, A., \& Van Cleemput, O. (1998). Mineralization of nitrogen in a clayey loamy soil amended with organic wastes enriched with $\mathrm{Zn}, \mathrm{Cu}$ and $\mathrm{Cd}$. Bioresource Technology, 64, 39-45.

Havilah, E., Rawlinson, L. V., \& Osborne, G. J. (1996). Biosolid as nitrogen fertilizers in coastal NSW. Sydney: NSW Agriculture Organic Waste Recycling Unit and Sydney Water, p.55-61. NSW Agriculture Organic Waste Recycling Unit and Sydney Water. Sydney.

Haynes, R. J. (1986). The decomposition process: Mineralization, immobilization, humus formation, and degradation. In: R. J. Haynes (Ed.), Mineral Nitrogen in the Plant-Soil System (pp. 52-109). Academic Press: Orlando, Florida, USA.

Heal, O. W., Anderson, J. M., \& Swift, M. J. (1997). Plant litter quality and decomposition: an historical overview. In: G. Cadish \& K. E. Giller (Eds.), Driven by Nature (pp. 3-30). CABI Wallingford.

Heumann, S., Böttcher, J., \& Springob, G. (2002). N mineralization parameters of sandy arable soils. Journal of Plant Nutrition and Soil Science, 165, 441-450. 
Hǿch-Jensen, H., Wollenweber, B., \& Schjoerring, J. K. (1997). Kinetics of nitrate and ammonium absorption and accompanying $\mathrm{H}^{+}$fluxes in roots of Lolium perenne $\mathrm{L}$. and $\mathrm{N}_{2}$-fixing Trifolium repens L. Plant, Cell \& Environment, 20, 1184-1192.

Hulugalle, N., Lal, R., \& Terkuile, C. H. H. (1986). Amelioration of soil physical properties by Mucuna after mechanized land clearing of a tropical rainforest. Soil Science, 141, 219-224.

Ibrikci, H., Comerford, N. B., Hanlon, E. A., \& Rechcigl, J. E. (1994). Phosphorus uptake by bahiagrass from Spodosols: Modeling of uptake from different horizons. Soil Science Society of America Journal, 58, 139-143.

Iglesias-Jimenez, E., \& Alvarez, C. E. (1993). Apparent availability of nitrogen in composted municipal refuse. Biology and Fertility of Soils, 16, 313-318.

Jan-Hammermeister, D. C., McGill, W. B., \& Jensen, T. L. (1994). Dynamic of ${ }^{15} \mathrm{~N}$ in two soil-plant systems following incorporation of $10 \%$ bloom and full bloom field pea. Canadian Journal of Soil Science, 74, 99-107.

Janzen, H. H., \& Kucey, R. M. N. (1988). C, N, and S mineralization of crop residues as influenced by crop species and nutrient regime. Plant and Soil, 106, 35-41.

Jensen, E. S. (1996). Compared cycling in a soil-plant system of pea and barley residue nitrogen. Plant and Soil, 182, 13-23.

Khalil, M. I., Hossain, M. B., \& Schmidhalter, U. (2005). Carbon and nitrogen mineralization in different upland soils of the subtropics treated with organic materials. Soil Biology and Biochemistry, 37, 1507-1518.

Khan, M., \& Scullion, J. (2002). Effects of metal (Cd, Cu, Ni, Pb or $\mathrm{Zn}$ ) enrichment of sewage-sludge on soil micro-organisms and their activities. Applied Soil Ecology, 20, 145-155.

Kithome, M., Paul, J. W., \& Bomke, A. A. (1999). Reducing nitrogen losses during simulated composting of poultry manure using adsorbents or chemical amendments. Journal of Environmental Quality, 28, 194-201.

Langmeier, M., Frossard, E., Kreuzer, M., Mäder, P., Dubois, D., \& Oberson, A. (2002). Nitrogen fertilizer value of cattle manure applied on soils originating from organic and conventional farming systems. Agronomie, 22, 789-800. 
Lasaridi, K., Protopapa, I., Kotsou, M., Pilidis, G., Manios, T., \& Kyriacou, A. (2006). Quality assessment of composts in the Greek market: The need for standards and quality assurance. Journal of Environmental Management, 80, 58-65.

Løes, A. K., \& Øgaard, A. F. (2001). Long-term changes in extractable soil phosphorus (P) in organic dairy farming systems. Plant and Soil, 237, 321-332.

Louahlia, S., Laine, P., Thornton, B., Ourry, A., \& Boucaud, J. (2000). The role of Nremobilisation and the uptake of $\mathrm{NH}_{4}{ }^{+}$and $\mathrm{NO}_{3}$-by Lolium perenne $\mathrm{L}$. in laminae growth following defoliation under field conditions. Plant and Soil, 220, 175-187.

Mafongoya, P. L., Giller, K. E., \& Palm, C. A. (1998). Decomposition and nitrogen release patterns of tree prunings and litter. Agroforestry Systems, 38, 77-97.

Maithani, K., Arunachalam, A., Tripathi, R. S., \& Pandey, H. N. (1998). Influence of leaf litter quality on $\mathrm{N}$ mineralization in soils of subtropical humid forest regrowths. Biology and Fertility of Soils, 27, 44-50.

Marschner, H. (1995). Mineral Nutrition of Higher Plants. San Diego.

Martin, J. P., \& Haider, K. M. (1980). Microbial degradation and stabilization of ${ }^{14} \mathrm{C}$ labelled lignins, phenols, and phenolics polymers in relation to soil humus formation. In: T. K. Kirk, T. Higuchi \& H. M. Chang (Eds.), Lignin Biodegradation: Micriobiology, Chemistry and Potential Applications (Vol. 2, pp. 425-429). CRC Press: West Palm Beach.

Melillo, J. M., Aber, J. D., \& Muratore, J. F. (1982). Nitrogen and lignin control of hardwood leaf litter decomposition dynamics. Ecology, 63, 621-626.

Mengel, K., \& Kirkby, E. A. (1982). Principles of Plant Nutrition (3rd ed.). International Potash Institute, Bern, Switzerland. pp 353.

Müller, M. M., Sundman, V., Soininvaara, O., \& Meriläinen, A. (1988). Effect of chemical composition on the release of nitrogen from agricultural plant materials decomposing in soil under field conditions. Biology and Fertility of Soils, 6, 78-83.

Myers, R. J. K., Palm, C. A., Cuevas, E., Gunatilleke, I. U. N., \& Brossard, M. (1994). The synchronisation of nutrient mineralisation and plant nutrient demand. In: P. L. Woomer \& M. J. Swift (Eds.), The Biological Management of Tropical Soil Fertility (pp. 81-116). Wiley: Chichester 
Nooman, H. J., \& Fuleky, G. (1995). Evaluation of the potential availability of phosphorus by plant uptake. In: H. F. Cook \& H. C. Lee (Eds.), Soil Management in Sustainable Agriculture (pp. 240-242). University of London: London.

Nordmeyer, H., \& Richter, J. (1985). Incubation experiments on nitrogen mineralization in loess and sandy soils. Plant and Soil, 83, 433-445.

Nwachukwu, O. I., \& Pulford, I. D. (2009). Soil metal immobilization and ryegrass uptake of lead, copper and zinc as affected by application of organic materials as soil amendments in a short-term greenhouse trial. Soil Use and Management, 25, 159-167.

Oberson, A., Tagmann, H. U., Langmeier, M., Dubois, D., Mäder, P., \& Frossard, E. (2010). Fresh and residual phosphorus uptake by ryegrass from soils with different fertilization histories. Plant and Soil, 1-17.

Palm, C. A. (1995). Contribution of agroforestry trees to nutrient requirements of intercropped plants. Agroforestry Systems, 30, 105-124.

Palm, C. A., \& Sanchez, P. A. (1991). Nitrogen release from the leaves of some tropical legumes as affected by their lignin and polyphenolic contents. Soil Biology and Biochemistry, 23, 83-88.

Peoples, M. B., Boyer, E. W., Goulding, K. W. T., Heffer, P., Ochwoh, V. A., Vanlauwe, B., Wood, S., Yagi, K., \& Van Cleemput, O. (2004). Pathways of nitrogen loss and their impacts on human health and the environment. In: A. R. Mosier, J. K. Syers \& J. R. Freney (Eds.), Agriculture and the Nitrogen Cycle: Assessing the Impact of Fertilizer Use on Food Production and the Environment (SCOPE) (pp. 53-69). Islan Press: Covelov, California, USA.

Porter, M. A., \& McMahon, T. A. (1987). Simulation of change in bulk density of the cultivated layer in a swelling clay soil. Soil and Tillage Research, 10, 147-166.

Quemada, M., \& Cabrera, M. L. (1995). Carbon and nitrogen mineralized from leaves and stems of four cover crops. Soil Science Society of America Journal, 59, 471-477.

Ranalli, G., Bottura, G., Taddei, P., Garavani, M., Marchetti, R., \& Sorlini, C. (2001). Composting of solid and sludge residues from agricultural and food industries. Bioindicators of monitoring and compost maturity. Journal of Environmental Science and Health, Part A, 36, 415-436. 
Rangeley, A. (1989). The suitability of plant tissue tests to indicate phosphorus deficiency in perennial ryegrass (Lolium perenne L.). Grass and Forage Science, 44, 9195.

Rowell, D. M., Prescott, C. E., \& Preston, C. M. (2001). Decomposition and nitrogen mineralization from biosolids and other organic materials: Relationship with initial chemistry. Journal of Environmental Quality, 30, 1401-1410.

Sarwar, G., Hussain, N., Mujeeb, F., Schmeisky, H., \& Hassan, G. (2003). Biocompost application for the improvement of soil characteristics and dry matter yield of Lolium perenne (Grass). Asian Journal of Plant Sciences, 2, 237-241.

SAS Institute. (2000). SAS Institute SAS/GRAPH software (Version 9.0). Cary, NC.: SAS Institute.

Sivapalan, K., Fernando, V., \& Thenabadu, M. W. (1985). N-mineralization in polyphenol-rich plant residues and their effect on nitrification of applied ammonium sulphate. Soil Biology and Biochemistry, 17, 547-551.

Smith, G. D., Jervis, A., Lennartsson, M., \& Bourne, W. F. (2001a). Laboratory methods of estimating potentially mineralizable nitrogen in organic potting mixes. II. Development of near infrared reflectance spectroscopy method. Communications in Soil Science and Plant Analysis, 32, 2769-2781.

Smith, G. D., Lennartsson, M., Bourne, W. F., \& Mead, A. (2001b). Laboratory methods of estimating potentially mineralizable nitrogen in organic potting mixes. I. Development of incubation and chemical methods. Communications in Soil Science and Plant Analysis, $32,2755-2768$.

Smith, J. H., \& Peterson, J. R. (1982). Recycling of nitrogen through land application of agricultural, food processing, and municipal wastes. In: F. J. Stevenson (Ed.), Nitrogen In Agricultural Soils (pp. 791-831). ASA: Madison, Wis.

Smith, M. T., \& Tibbet, M. (2004). Nitrogen dynamics under Lolium perenne after a single application of three different sewage sludge types from the same treatment stream. Bioresource Technology, 91, 233-241.

Soumaré, M., Tack, F. M. G., \& Verloo, M. G. (2003). Ryegrass response to mineral fertilization and organic amendment with municipal solid waste compost in two tropical agricultural soils of Mali. Journal of Plant Nutrition, 26, 1169-1188. 
Stanford, G. S., \& Smith, S. J. (1972). Nitrogen Mineralization Potentials of Soils 1. Soil Science Society of America Journal, 36, 465-465.

Swift, M. J., Heal, O. W., \& Anderson, J. M. (1979). Decomposition in Terrestrial Ecosystems. University of California Press: Berkeley. 509 pp.

Tilman, D., Cassman, K. G., Matson, P. A., Naylor, R., \& Polasky, S. (2002). Agricultural sustainability and intensive production practices. Nature, 418, 671-677.

Toor, G. S., Hunger, S., Peak, J. D., Sims, J. T., \& Sparks, D. L. (2006). Advances in the characterization of phosphorus in organic wastes: Environmental and agronomic applications. Advances in Agronomy, 89, 1-72.

Tucker, T. C. (1984). Diagnosis of nitrogen deficiency in plants. In: E. D. Hauck (Ed.), Nitrogen in crop production. American Society of Agronomy. Madison, Wis. (pp. 247262). American Society of Agronomy: Madison, WI.

Vagstad, N., Broch-Due, A., \& Lyngstad, I. (2001). Direct and residual effects of pulp and paper mill sludge on crop yield and soil mineral N. Soil Use and Management, 17, 173-178.

Vasconcelos, E., Cabrai, F., \& Cordovil, C. M. S. (1999). Wheat yield and leachability of phosphorus and mineral nitrogen in pig slurry amended soils. Communications in Soil Science and Plant Analysis, 30, 2245-2257.

Veeken, A., Nierop, K., Wilde, V., \& Hamelers, B. (2000). Characterisation of NaOHextracted humic acids during composting of a biowaste. Bioresource Technology, 72, 3341.

Velthof, G. L., Van Beusichem, M. L., Raijmakers, W. M. F., \& Janssen, B. H. (1998). Assessment of plant available nutrients in organic products using an airlift bioreactor. Journal of Environmental Quality, 27, 1261-1267.

Vigil, M. F., \& Kissel, D. E. (1991). Equations for estimating the amount of nitrogen mineralized from crop residues. Soil Science Society of America Journal, 55, 757-761.

Voroney, R. P., Paul, E. A., \& Anderson, D. W. (1989). Decomposition of wheat straw and stabilization of microbial products. Canadian Journal of Soil Science, 69(1), 63-77.

Wivstad, M. (1999). Nitrogen mineralization and crop uptake of $\mathrm{N}$ from decomposing $15 \mathrm{~N}$ labelled red clover and yellow sweetclover plant fractions of different age. Plant and Soil, 208, 21-31. 
Yardim, E. N., Arancon, N. Q., Edwards, C. A., Oliver, T. J., \& Byrne, R. J. (2006). Suppression of tomato hornworm (Manduca quinquemaculata) and cucumber beetles (Acalymma vittatum and Diabotrica undecimpunctata) populations and damage by vermicomposts. Pedobiologia, 50, 23-29.

Yousif, A. M., \& Abdalla, M. A. (2009). Variations in nitrogen mineralization from different manures in semi-arid tropics of Sudan with reference to salt-affected soils. International Journal of Agriculture and Biology, 11, 515-520.

Zaman, M., Cameron, K. C., Di, H. J., \& Noonan, M. J. (1998). Nitrogen mineralisation rates from soil amended with dairy pond waste. Australian Journal of Soil Research, 36, 217-230.

Zucconi, F., \& De Bertoldi, M. (1987). Compost specifications for the production and characterization of compost from municipal solid waste. In: M. de Bertoldi, M. P. Ferranti, P. L'Hermite \& F. Zucconi (Eds.), Compost: Production, Quality and Use (pp. 30-50). Elsevier Applied Science: Essex. 


\section{Efficacy of Compost and Vermicompost in controlling Cotton Bacterial Blight (Xanthomonas campestris pv. malvacearum)}

\subsection{Introduction}

The transformation of the agricultural and industrial wastes into compost suppressive to plant pathogens would be a splendid result, not only for agriculture but also for the environment and, above all, human health. We must thus reconsider our view of these organic materials not as a waste item to be disposed, but as a valuable resource, put to the highest and best use possible.

About 200,000 tons of cotton and 500,000 tons per annum of wheat and tons of other crops' residues are annually burnt in the irrigated farming system of Gezira-Managil, Sudan, which extends over 1,260,000 ha (personal communications Ahmed, 2007). In particular, cotton residues must be collected and quick burnt in order to prevent the spread of residue-borne diseases such as bacterial blight (black-arm disease) which exacerbate up to $35 \%$ loss in the productivity. Bacteria may propagate in the raw materials during collection, transport, and storage and are involved in the composting process itself. During decomposition, especially in thermophilic processes, the bacterial pathogens are reduced in number. It has to be considered then that they often propagate in the raw materials before being processed (Böhm, 2007).

Compost and vermicompost have been found to show enhanced suppression of plant diseases caused by soil-borne nematodes, fungi and bacteria, in various cropping systems (Hoitink \& Fahy, 1986; Ringer, 1998; Schönfeld et al., 2003). Conversely, an increase of disease incidence due to compost and vermicompost applications has also been demonstrated (Hoitink \& Boehm, 1999; Tuitert et al., 1998).

The fact that compost and vermicompost applications can affect the suppression of disease in cropping systems in positive, neutral, or even negative ways still makes the applications of compost, and vermicompost complicated as a universal strategy to suppress plant disease. The attack by soil or residue-borne plant pathogens can be inhibited or stimulated using compost and vermicompost: (1) directly through their chemical and physical properties, (2) through the present microflora, (3) by stimulating 
the (antagonistic) microflora in soil and around plant roots, and (4) by inducing plants with good stands (van Elsas \& Postma, 2007).

Hoitink and Fahy (1986) reported that, control of diseases through composting includes killing of plant pathogens present in wastes during and after the high-temperature process. Specific physical, chemical, and biological properties of composts may have a major effect on their suppressiveness. Activity of antagonists involved in biological control is affected by nutrients present in compost. Only few studies have investigated the suppression of soil-borne plant pathogens by vermicomposts (Szczech et al., 1993), or disease suppression in the presence of earthworms or use of body wall and gut extracts (Shobha \& Kale, 2008; Stephens \& Davoren, 1997; Stephens et al., 1994) or depression of plant-parasitic nematodes by vermicomposts (Arancon et al., 2002).

\subsubsection{Parameters that relate to compost disease suppressiveness}

Compost disease suppressiveness is defined as the efficacy of the compost enriched with biological control agents to mitigate phytopathogens (Pugliese et al., 2011). In spite of the numerous efforts that have been devoted to find determinants (indicators) of disease suppressiveness, there is still a general lack of understanding of what determines the disease-suppressive status of compost or vermicompost. However, it is very likely that disease suppressiveness of compost or vermicompost can be caused by a complex interplay of a range of abiotic ( $\mathrm{pH}, \mathrm{C}: \mathrm{N}$, organic matter quality, etc.) and biotic (predators, antagonists, and competitors for nutrients) factors. 
Prediction of suppressiveness of compost or vermicompost is complicated not only due to the complexity of the materials themselves, but also due to the different soil-borne pathogens (fungi, nematodes, bacteria) that should be suppressed. It is obvious that an ideal suppressive compost or vermicompost should inhibit a broad range of pathogens, but various pathogens will probably react differently in relation to disease-suppressivity. Although general indicators for suppression are not available, several promising examples of disease suppression have been described for specific situations and diseases. This clearly indicates a relationship between disease suppression and particular chemical, physical, and biological characteristics in the substrates.

\subsubsection{Compost, vermicompost and materials' maturity}

The maturity and stability of compost and vermicompost are important for the degree of disease suppressiveness that can be achieved. In stable compost and vermicompost, easily degradable carbon sources have been used by the microorganisms, leading to a stable microbiological system. Extremely stable compost and vermicompost are expected to have little effect on soil suppressiveness. In fresh compost and vermicompost, nutrient sources have not been depleted; when such immature compost or vermicompost is applied to soil, plant diseases can be curbed, but can also be stimulated. According to Hoitink and Boehm, (1999), it is the partially stabilized (matured) and fully colonized compost that will have optimal disease-suppressive characteristics.

\subsubsection{Microbial succession during the composting and vermicomposting}

There is little detailed information on kill at lower temperatures during composting. However, the literature on control of soil-borne pathogens by solar heating (solarization) may be a useful guide for this purpose, since it also describes data on thermal inactivation caused by long-time exposure to lower temperatures (Katan, 1981). Factors other than heat, such as antibiotics and ammonia, may destroy such pathogens during composting. Even so, variability in concentrations of these factors and their effects during composting is such that it is essential to rely on temperature time exposure for destruction (Burge et al., 1981). For most cases, exposure to heat can explain the lack of survival of plant pathogens in naturally infested plant tissues (Hoitink \& Fahy, 1986). 


\subsubsection{Correlation of disease suppressiveness with microbial characteristics}

Attempts have been made to correlate the degree of disease suppressiveness of compost or vermicompost by measuring the microbial activities in the product itself. The suppressiveness against disease was found to be correlated with general microbial activity, as measured by fluorescein diacetate (FDA) hydrolysis (Craft \& Nelson, 1996). Suppressiveness was also largely explained by organic matter quality (i.e., an index indicating the suitability of the organic matter of the soil-compost mix as a food source for the microflora). It is likely that the community structure (numbers, activity, and diversity) of the microflora present in the compost, and vermicompost determines the degree of suppression of plant disease.

Attempts have also been made to index composts for numbers of specific microbial groups that are known to inhibit a wide range of phytopathogens. High numbers of actinomycetes were present in those compost types that showed a phytopathogensuppressive power. The ratio of actinomycetes to total bacteria in mature, diseasesuppressive compost was 200-fold higher than in disease-conducive compost (Craft \& Nelson, 1996; Tuitert et al., 1998).

Actinomycetes are key organisms in the decomposition of various organic substances, and they are important producers of antibiotics, vitamins, and many enzymes. Another microbial group that was studied in relation to compost and vermicompost suppressiveness was the fungi of the genus Trichoderma. Compost prepared from lignocellulosic materials such as tree bark with suppressive properties towards Rhizoctonia is predominantly colonized by Trichoderma spp. (Hoitink \& Boehm, 1999).

It is likely that, in addition to actinomycetes and Trichoderma spp., other microorganisms also correlate with suppressiveness of compost. Boulter et al. (2002) found that a high percentage of the bacterial isolates from compost exhibited antagonistic activity in vitro against various fungal pathogens $(19-52 \%$ of isolates inhibited several turfgrass pathogens). A range of different bacterial and fungal groups, such as Pseudomonads, Serratia spp., Burkholderia spp., Bacillus and Peanibacillus spp., and specific 
(mycoparasitic) fungi, are known to be able to exert antagonism against phytopathogenic bacteria and fungi.

For efficient disease suppression, a range of different properties of the microflora are thought to be important. A high microbial diversity, as well as the presence of specific suppressive microorganism(s), might be necessary. Further research in this area depends on trial and error, aiming for practical solutions for healthy crop growth or preparing a good quality of compost and vermicompost (van Elsas \& Postma, 2007).

\section{2. $\underline{\text { Aim }}$}

The study was intended to evaluate the potential of produced compost and vermicompost as possible alternatives to mitigate or suppress the phytopathogenic bacteria (Xanthomonas campestris pv. malvacearum) survival using semi-selective media. Preliminary results have been reported.

\subsection{Materials and methods}

\subsubsection{Compost and vermicompost preparation}

The survival of phytopathogenic bacteria during composting and vermicomposting was studied, and samples were monthly analyzed. Infected cotton residues were mixed with soil and farm yard manure (FYM) (Table 7.1) in plastic barrels for compost and vermicompost (CPF and VERF respectively) into two different ratios. The first one was 5:1:1 ratio on a dry weight basis of cotton residue, FYM and soil respectively, and the second one was a ratio of 5:1 of only cotton residue to soil for the compost (CP) and vermicompost (VER).

Cotton residues were chopped manually to reduce the particle size. Some of the cotton straw was kept in the laboratory as untreated checks. The moisture content of the materials was adjusted to $65-75 \%$ of water-holding capacity by dry weight basis for the compost and around $75-80 \%$ for the vermicompost at the start of the decomposition process and maintained throughout the experiment. The barrel containing compost was kept to receive the direct sun light while the barrel for the vermicompost remained under shelter to keep the optimum temperature for the earthworms $\left(25-30^{\circ} \mathrm{C}\right)$. 
Earthworms (Lumbricus terrestris) were inoculated with the materials for vermicomposting. Plastic meshes were placed over the vermicompost barrel to allow adequate aeration and to prevent earthworms from escape. Every two weeks, the materials were turned and the outer materials moved towards the center for homogeneity. Temperature of the compost and vermicompost was taken daily at mid-day with a thermometer (Table 7.3. and Fig.7.2).

The carbon content was determined by the Walkley-Black method (Nelson \& Sommers, 1982) and total nitrogen with the Kejldahl method (Bremner \& Mulvaney, 1982). The pH was measured using water suspension of 10:1 of water to material using a digital $\mathrm{pH}$ meter.

Table 7.1. Initial materials utilized in compost and vermicompost production

\begin{tabular}{|l|l|l|l|}
\hline \multicolumn{2}{|c|}{ Soil } & FYM & Cotton residue \\
\hline \% C N & 0.94 & 28.33 & 45.2 \\
C:N & 0.06 & 0.99 & 1.3 \\
pH(1:5) $_{\text {EC (1:5) }}$ & 15.67 & 28.4 & 34.77 \\
\% Cellulose & 8.1 & 6.7 & 5.40 \\
\% Hemicellulose & 1.95 & 2.05 & 0.20 \\
\% Lignin & & 43.53 & 36.52 \\
\% Phenolics & & 14.99 & 19.02 \\
\hline
\end{tabular}




\subsubsection{Detection of pathogen survival in cotton residues compost and vermicompost}

Random samples were taken from the compost and vermicompost every 30 days during the entire experiment period. Three replicates of each material were sampled on every occasion. To isolate and determine total microbial population, the standard plate dilution method with $10 \mathrm{~g}$ of material was used (Schaad, 1988). Samples were cultured onto semiselective agar medium plate (Table 7.2) following the methods proposed by the International Seed Testing Association (ISTA) (2007). Plates were incubated for 3-4 days at 28-30 ${ }^{\circ} \mathrm{C}$. After the incubation period, Xanthomonas campestris pv. campestris colonies are small, pale yellow, mucoid and surrounded by a zone of starch hydrolysis. This zone appears as a halo that may be easier to see with a black background. Colonies may show marked variation in size. Results are shown as the number of colony-forming units per gram of fresh material (CFU/g). 
Table 7.2. Semi-selective agar medium ( mCS20ABN)

\begin{tabular}{|l|l|}
\hline Compound & $\mathrm{g} / \mathrm{L}$ \\
\hline Soya Peptone & 2.0 \\
Bacto Tryptone & 1.59 \\
$\mathrm{KH}_{2} \mathrm{PO}_{4}$ & 0.33 \\
$\left(\mathrm{NH}_{4}\right)_{2} \mathrm{HPO}_{4}$ & 0.4 \\
$\mathrm{MgSO}_{4} \cdot 7 \mathrm{H}_{2} \mathrm{O}$ & 6.0 \\
L-Glutamine & 1.0 \\
L-Histidine & 1.0 \\
D-Glucose $(\mathrm{Dextrose})$ & 25.0 \\
Soluble starch & 15.0 \\
Bacto Agar & $200 \mathrm{mg}(1 \mathrm{ml})$ \\
Cyclohemide $(200 \mathrm{mg} / \mathrm{ml} 70 \% \mathrm{EtOH})$ & $40 \mathrm{mg}(1 \mathrm{ml})$ \\
Neomycinb $(40 \mathrm{mg} / \mathrm{ml}$ in 20\% EtOH) & $100 \mathrm{mg}(1 \mathrm{ml})$ \\
Bacitracin $(100 \mathrm{mg} / \mathrm{ml}$ in $50 \% \mathrm{EtOH})$ & $1000 \mathrm{ml}$ \\
Distilled water & \\
\hline \hline
\end{tabular}




\subsection{Statistical analysis}

Data of the pathogen colony numbers were submitted to logarithmic transformation before statistical analysis. A value of 5 was added before $\log _{\mathrm{e}}$ transformation to avoid taking $\log _{\mathrm{e}}$ values of zero. Statistical analysis was carried out with the statistical programme SAS 9.0 for windows (SAS Institute, 2000). One-way analysis of variance (ANOVA) was performed to test for the effect of treatments on the survival of the phytopathogenic bacteria. Multiple comparison tests (Fisher's least significant difference) were applied to separate means when ANOVA revealed differences $(P<0.05)$.

\subsection{Results and discussion}

Temperatures measured throughout the composting and vermicomposting periods are presented in Figure 7.2, and the biweekly mean measurements are depicted in Table 7.3. The efficacy of composting and vermicomposting over time is presented in Figure 7.1. The highest pathogen colonies' number was detected in the first sampling date (first month), thereafter, the pathogen populations progressively decreased with the subsequent sampling dates (towards the end of the experiment $)(P<0.05$, Fig.7.1).

Table 7.3. Biweekly mean temperature $\left({ }^{\circ} \mathrm{C}\right)$ of compost and vermicompost during the entire experiment period

\begin{tabular}{|c|c|c|c|c|c|}
\hline \multicolumn{6}{|c|}{ Vermicomposting } \\
\hline & Jan. & Feb. & March & April & May \\
\hline $1^{\text {st }}$ reading & 25.42 & 25.57 & 30.51 & 32.70 & 34.49 \\
\hline $2^{\text {nd }}$ reading & 22.61 & 23.93 & 31.99 & 34.82 & 35.70 \\
\hline \multicolumn{6}{|c|}{ Composting } \\
\hline $1^{\text {st }}$ reading & 40.69 & 41.20 & 48.20 & 49.54 & 51.28 \\
\hline $2^{\text {nd }}$ reading & 37.01 & 40.11 & 48.90 & 50.58 & 51.80 \\
\hline
\end{tabular}


Composting and vermicomposting successfully decreased the pathogen populations; the pathogen population in the control was the highest throughout the experiment period because samples were not subjected to any decomposition process and kept for comparison. At most of the sampling dates, the pathogen population was lower in the vermicompost compared to that found in the compost. Differences between materials without FYM (CP \& VER) and with FYM (CPF \& VERF) were significant at all sampling dates except for the pathogen population counted in the vermicompost (VER \& VERF) after 150 days of decomposition. Pathogen populations in the compost, vermicompost, and the control remained significant over time $(P<0.05)$ towards the end of the experiment.

For the compost, the difference in the pathogen population in the materials prepared without FYM $(\mathrm{CP})$ was not significant $(P>0.05)$ from the pathogen population in the control; the reduction in the pathogen population (calculated as the difference between pathogen population in the $\mathrm{CP}$ and the control) was only $0.16 \%$; significantly increased to $41.5 \%$ after 60 days, decreased after 90 days to $24.3 \%$ but slightly increased to $27.2 \%$ after 120 days, and then increased at the end of the experiment period to $38.9 \%$. The reduction in pathogen population reflects the significant different observed over time, where, pathogen population significantly decreased with time $(P<0.05$; Fig. 7.1$)$.

Regarding the compost prepared with FYM (CPF), the pathogen population counted at all sampling dates were significantly different $(P<0.05$; Fig. 7.1$)$. The reduction in the pathogen population was $1.7 \%$ after 30 days, significantly increased to $54.9 \%$ at 60 days, reduced to $22.9 \%$ at 90 days, relatively increased to $25.3 \%$ at 120 days, and then increased to $37.8 \%$ at 150 days.

The pathogen population counted in the vermicompost (VER \& VERF) at all sampling dates were significantly different $(P<0.05)$ except for the populations counted after 150 (Fig.7.1). The highest pathogen population was counted after 30 days and the lowest measured after 150 days. The pathogen population in the vermicompost without FYM (VER) reduced with time. The reductions were $11.1,26.4,39.5,60.5$, and $88.9 \%$ for samples taken at $30,60,90,120$, and 150 days.

The reduction in pathogen populations in the vermicompost with FYM (VERF), over time was as the same as that observed for vermicompost without FYM (VER). The reduction percentage after 30 days was $14.6 \%$ progressively increased to $22.5 \%, 40.0,58.9$, and $88.9 \%$ after $60,90,120$, and 150 days. 
The efficacy of compost and vermicompost to suppress the phytopathogen increased with time (Hoitink \& Boehm, 1999); therefore, a correlation of pathogen populations and decomposition time was conducted.

A significant negative correlation was found $(r=0.71 ; P \leq 0.05)$ between the pathogen populations and time, which demonstrates that increasing decomposition time effectively reduces the phytopathogen population and hence indicating the progress of the compost and vermicompost towards maturity.

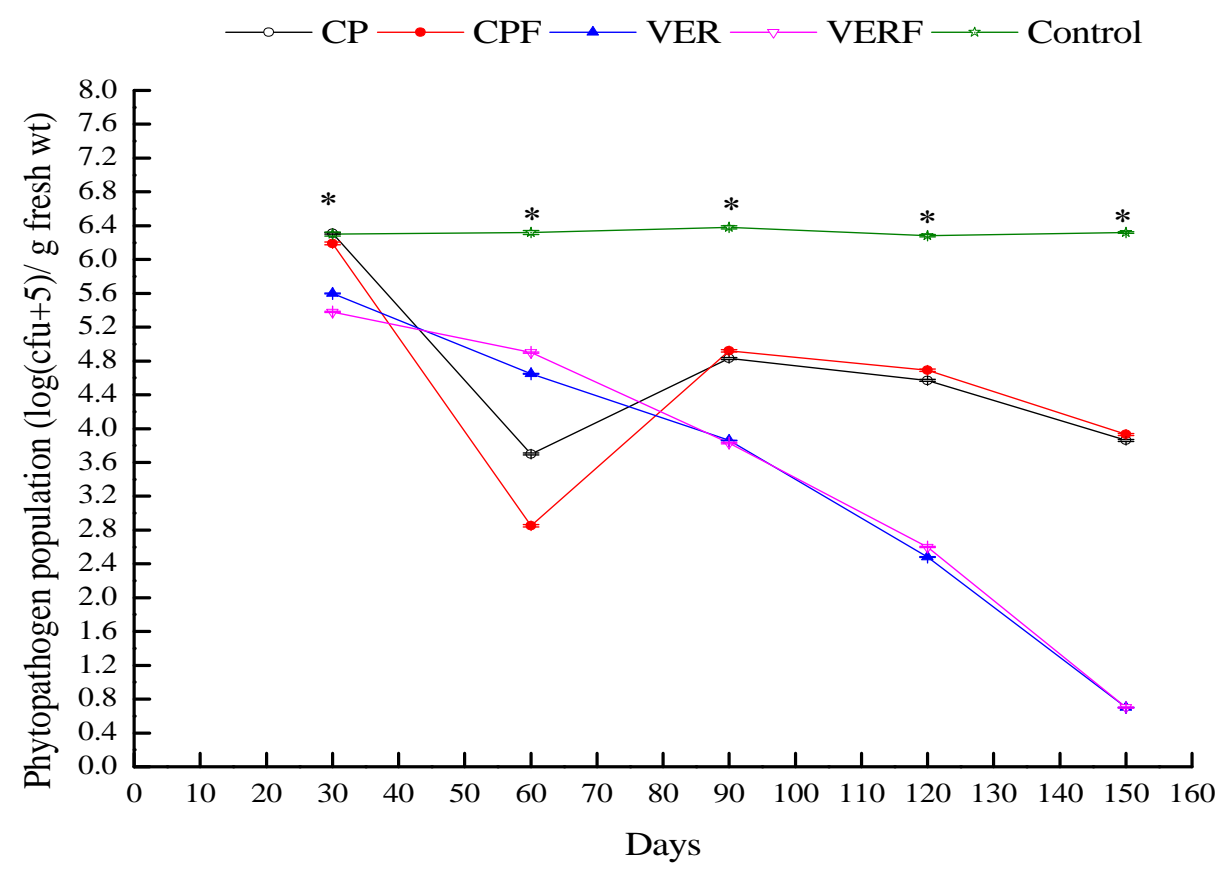

Fig.7.1: Changes in time in numbers of pathogen treated with composting and vermicomposting. CP: composted cotton residues without FYM; CPF: composted cotton residues with FYM; VER: vermicomposted cotton residues without FYM; vermicomposted cotton residues with FYM; and Control. Means within the same date followed by $*$ are significantly different at $P \leq 0.05$ (Means \pm SE). 


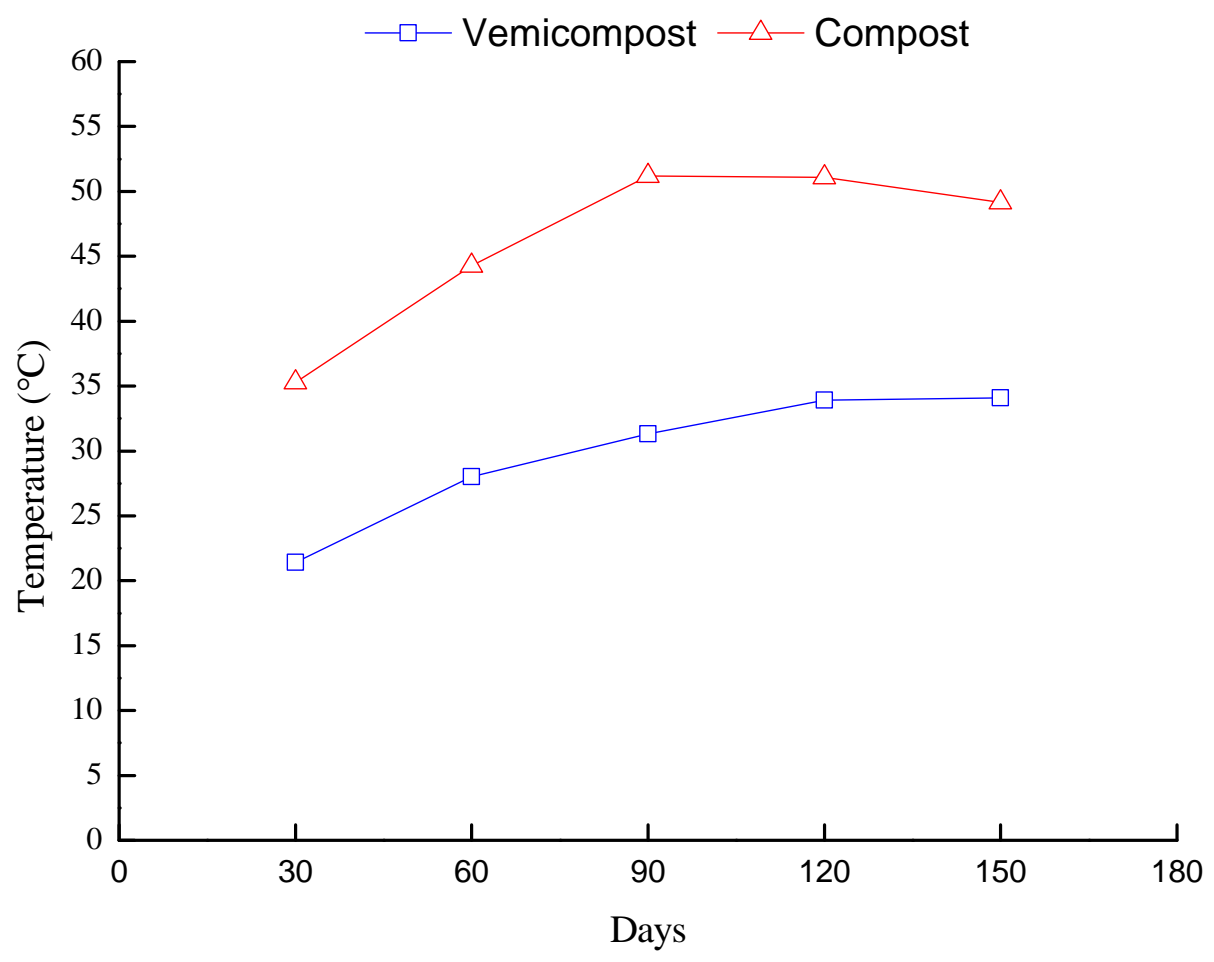

Fig.7.2. Temperature $\left({ }^{\circ} \mathrm{C}\right)$ of the compost and vermicompost at different sampling dates during the entire experiment period.

The reduction of pathogen populations over time in the compost is consistent with the few studies on the fate of plant pathogenic bacteria in compost heaps. These studies showed that composting effectively sanitize crop residues infested with these pathogens (Bollen \& Volker, 1996). Many workers suggested that the elimination was mainly due to the high temperatures reached during the process (Aguilar et al., 2010; Bollen, 1993; Hoitink \& Fahy, 1986).

Small-scale compost piles, as in our case, may not achieve adequate temperature-exposure time, but commercial-scale operations should achieve the effective pathogen kill, if adequate precautions are taken (Ylimäki et al., 1983), however, the mean temperature of this experiment was near or equal to $50{ }^{\circ} \mathrm{C}$, especially after 90 days onwards (Table $7.3 \&$ Fig. 7.2). This may be the consequence of the daily exposure of the compost barrel to the direct sun coupled with the self-heating during the decomposition process. The long daily exposure time (> 6 hrs.) of this study within this temperature range could be adequate to exert an inhibitory effect on the phytopathogen survival (Table 7.3).

Different exposure times to the temperature generated by microorganisms has been reported. Our findings are similar to results reported with less exposure time with different 
phytopathogens, for instance Verticillium dahlia was killed by a 10 -min. exposure to $50{ }^{\circ} \mathrm{C}$ heat (Nelson \& Wilhelm, 1958), whereas, Armillaria mella required $30 \mathrm{~min}$. (Munnecke et al., 1976) and Rhizoctonia solani needed $60 \mathrm{~min}$. at $50{ }^{\circ} \mathrm{C}$ (Newton, 1931).

Increase the temperature of the plies to $\geq 55{ }^{\circ} \mathrm{C}$ relatively shorten the exposure time needed to suppress the pathogens (Elorrieta et al., 2003; Nelson \& Wilhelm, 1958; Newton, 1931), for instance, Bollen (1969) reported that most of the plant pathogens were killed by 30-min. exposure to $55{ }^{\circ} \mathrm{C}$. In other studies, no phytopathogenic bacteria were found after $15 \mathrm{~h}$ of exposure at $50{ }^{\circ} \mathrm{C}$ and after $1 \mathrm{~h}$ exposure at $60{ }^{\circ} \mathrm{C}$. Increasing both the temperature and exposure time effectively eliminate the pathogens; for example, at $70{ }^{\circ} \mathrm{C}$, only very few pathogens were detected after $15 \mathrm{~min}$ of exposure, and none survived $30 \mathrm{~min}$. (Elorrieta et al., 2003).

The heat generated in the thermophilic phase of composting usually exceeds the level required to cause thermal death of most of the plant pathogens (Bollen, 1993), but prolonged decomposition periods tends to fluctuate temperature reaching the ambient temperature at the edges (Bollen, 1985; Hoitink et al., 1976; Ylimäki et al., 1983; Yuen \& Raabe, 1984). However, some pathogens may even survive the lethal temperature; for instance, Xanthomonas malvacearum survived treatments within the compost pile of cotton gin trash (Sterne et al., 1979).

It is likely based on the results reported by Yuen and Raabe, (1984) that eradication of pathogens depends on their location within the composting pile. The periodic turning of the compost equally exposes all materials in the barrel to the above-mentioned temperature range $\left(\geq 50{ }^{\circ} \mathrm{C}\right.$ ) that reduced disease-producing organisms.

Even with turning, the outer portions of the materials at the turning intervals, did not reach the temperature lethal to disease-producing organisms but generally, composting reduced the pathogen population; this could be due to the maturity of the compost at edges where naturally suppressive microorganisms may be present (Kowk et al., 1987). The results agree with those of Yuen and Raabe (1984) who reported that composting completely inactivated pathogens when incorporated and moved through the bin by turning and temperatures in the corners of the compost bin, although it did not reach lethal levels successfully minimized the pathogenic fungi.

Vermicomposts are produced from organic wastes through interactions between earthworms and microorganisms. They are produced by an aerobic and mesophilic metabolic process 
(Edwards, 2004b). Disease suppression by vermicomposts has been attributed to the activities of competitive or antagonistic microorganisms. Hoitink and Kuter (1985) and Hoitink and Fahy (1986), found that samples removed from the edge of the mature compost were suppressive and antagonists of plant pathogens appear to survive in the outer low-temperature zone of the compost pile. Yuen and Raabe (1984) have shown that, composting process eliminated the pathogens at temperature close to ambient throughout the experiment without reaching $30{ }^{\circ} \mathrm{C}$. Bacteria and nematodes are known to be more sensitive to heat than most fungal pathogens (Hoitink \& Fahy, 1986).

Other factors which reduce the pathogens are either competition between pathogens and other microorganisms for nutrients and energy, or destruction of pathogen propagules such as spores (Edwards et al., 2006; Hoitink et al., 1996; Ylimäki et al., 1983) or the production of toxic substances during the decomposition process (Yuen \& Raabe, 1984); for instance, several phenolic compounds may also contribute to control phytopathogenic bacteria (Elorrieta et al., 2003).

The use of vermicomposts suppressed significantly the diseases Pythium, Rhizoctonia and Verticillium (Chaoui et al., 2002) and other soil-borne diseases in crops due to the antimicrobial properties (Shobha \& Kale, 2008). Xanthomonas campestris pv. carotovora strongly inhibited with compost tea in the laboratory studies as well as in the field (Reiten \& Salter, 2002) and also by the earthworms' extracts (Shobha \& Kale, 2008).

There is good evidence that earthworms promote microbial activity and diversity in organic wastes to levels even greater than those in thermophilic composts by providing fragmented organic materials with much larger surface area for microbial growth and activity (Edwards, 1998a; Edwards et al., 2010; Yardim et al., 2006). This conclusion apparently supported our results, although we did not study the microbial composition but the general reduction in the pathogen populations may support our speculation.

The exact suppression mechanisms cannot be identified in this exploratory experiment. Therefore, further knowledge of the mechanisms that influence the interactions between the beneficial microorganisms, and the pathogens, in relation to the organic matter in the compost, and vermicompost is needed.

The reduction of the phytopathogens with time in this study of both compost and vermicompost that could indicate maturity is in accordance with Hoitink and Fahy, (1986), who observed an enhanced suppression of Rhizoctonia disease with time. Possibly, the 
microflora of mature compost and vermicompost serves as a food base for antagonists and thus supports the activity over a longer period (Hoitink \& Fahy, 1986) or beneficial microorganisms may re-colonize the substrates when maturity achieved and hence, suppress the phytopathogen. Therefore, maturity and stability of compost and vermicompost are important for the degree of disease suppressiveness that can be achieved (Hoitink \& Boehm, 1999).

\subsection{Conclusions}

Success or failure of any compost or vermicompost for disease control depends on the nature of the raw materials, the degree of maturity, as well as, the length of decomposition (Hoitink \& Fahy, 1986). In conclusion:

- the overall results of composting corroborated observations made with other different pathogens and viruses (Aguilar et al., 2010; Avgelis \& Manios, 1992; Bollen, 1985; Hoitink et al., 1976; Lopez-Real \& Foster, 1985; Ylimäki et al., 1983).

- the study revealed that the phytopathogen populations were significantly suppressed, furthermore, the results could represent a tentative indication of the potential of composting and vermicomposting to control and reduce the phytopathogen.

- databases that can be used for comparison of disease-suppressive of the compost and vermicompost prepared from cotton residues are lacking.

\subsection{Outlook}

Further studies to investigate the relationship between disease suppression and specific chemical, physical, and biological characteristics of the compost and vermicompost are needed. Suggested investigations and tests includes, among others, the in vitro tests using potato dextrose agar (PDA) or small pots containing suppressive compost or randomly amplified polymorphic DNA analysis and polymerase chain reaction (PCR) (Abbasi et al., 1999; Civilini et al., 2000). 


\section{8. $\underline{\text { References }}$}

Abbasi, P. A., Miller, S. A., Meulia, T., Hoitink, H. A. J., \& Kim, J. M. (1999). Precise detection and tracing of Trichoderma hamatum 382 in compost-amended potting mixes by using molecular markers. Applied and Environmental Microbiology, 65, 5421-5421.

Aguilar, M. I., Guirado, M. L., Melero-Vara, J. M., \& Gómez, J. (2010). Efficacy of composting infected plant residues in reducing the viability of Pepper mild mottle virus, Melon necrotic spot virus and its vector, the soil-borne fungus Olpidium bornovanus. Crop Protection, 29, 342-348.

Ahmed, E. (2007). Cotton residues, wheat and different other crops in the Gezira-Managil irrigated farming systems. Wad Medani, Sudan.

Arancon, N. Q., Edwards, C. A., Lee, S. S., \& Yardim, E. (2002). Management of plant parasitic nematode populations by use of vermicomposts. Paper presented at the Proceedings Brighton Crop Protection Conference - Pests and Diseases, 8B-2, 705-716.

Avgelis, A. D., \& Manios, V. I. (1992). Elimination of cucumber mottle mosaic tobamovirus by composting infected cucumber residues. Acta Horticulturae, 302, 311-314.

Böhm, R. (2007). Pathogenic agents. Waste Management Series, 8, 177-200.

Bollen, G. J. (1969). The selective effect of heat treatment on the microflora of a greenhouse soil. European Journal of Plant Pathology, 75, 157-163.

Bollen, G. J. (1974). Fungal recolonization of heat-treated glasshouse soils. Agro-ecosystems, $1,139-155$.

Bollen, G. J. (1985). The fate of plant pathogens during composting of crop residues. In: J. K. R. Gasser (Ed.), Composting Agricultural and Other Wastes (pp. 282-289). Elsevier Appl. Sci.: London / New York.

Bollen, G. J. (1993). Factors involved in inactivation of plant pathogens during composting of crop residues. Scienceand Engineering of Composting: Design, Environmental, Microbiological and Utilization Aspects. Wooster, Ohio. The Ohio State University, 301-318.

Bollen, G. J., \& Volker, D. (1996). Phytogenic aspects of composting. In: M. De Bertoldi, P. Sequi, B. Lemmes \& T. Papi (Eds.), The Science of Composting (pp. 233-246.). Blackie Academic \& Professional: Glasgow, UK.

Boulter, J. I., Trevors, J. T., \& Boland, G. J. (2002). Microbial studies of compost: bacterial identification, and their potential for turfgrass pathogen suppression. World Journal of Microbiology and Biotechnology, 18, 661-671.

Bremner, J. M., \& Mulvaney, C. S. (1982). Total nitrogen. In: A. L. Page, R. H. Miller \& D. R. Keeny (Eds.), Methods of Soil Analysis Part 2. Chemical and Microbiological Properties (2 ed., pp. 595-622). Agronomy Monograph No. 9: SSSA, Madison WI.

Burge, W. D., Colacicco, D., \& Cramer, W. N. (1981). Criteria for achieving pathogen destruction during composting. Journal of Water Pollution Control Federation, 53, 16831690 . 
Chaoui, H., Edwards, C. A., Brickner, A., Lee, S. S., \& Arancon, N. Q. (2002). Suppression of the plant diseases, Pythium (damping-off), Rhizoctonia (root rot) and Verticillium (wilt) by vermicomposts. Paper presented at the Proceedings Brighton Crop Protection ConferencePests and Diseases 8B-3. 711-716.

Civilini, M., Venuti, F., De Bertoldi, M., \& Damante, G. (2000). Recovery of Salmonella typhimurium from compost with the IMS-PCR method. Waste Management \& Research, 18, 572-572.

Craft, C. M., \& Nelson, E. B. (1996). Microbial properties of composts that suppress damping-off and root rot of creeping bentgrass caused by Pythium graminicola. Applied and Environmental Microbiology, 62, 1550-1550.

Doube, B. M., \& Brown, G. G. (1998). Life in a complex community: Functional interactions between earthworms, organic matter, microorganisms, and plants. In: C. A. Edwards (Ed.), Earthworm Ecology (pp. 179-211). St. Lucie Press: Boca Raton, USA.

Edwards, C. A. (2004). The use of earthworms in processing organic wastes into plant growth media and animal feed protein. In: C. A. Edwards (Ed.), Earthworm Ecology (pp. 327-354). CRC Press: Boca Raton, Florida.

Edwards, C. A., Arancon, N. Q., \& Greytak, S. (2006). Effects of vermcompost teas on plant growth and disease. BioCycle, 47, 28-31.

Edwards, C. A., Arancon, N. Q., Vasko-Bennett, M., Askar, A., \& Keeney, G. (2010). Effect of aqueous extracts from vermicomposts on attacks by cucumber beetles (Acalymna vittatum)(Fabr.) on cucumbers and tobacco hornworm (Manduca sexta) (L.) on tomatoes. Pedobiologia, 53, 141-148.

Elorrieta, M. A., Suarez-Estrella, F., Lopez, M. J., Vargas-Garcia, M. C., \& Moreno, J. (2003). Survival of phytopathogenic bacteria during waste composting. Agriculture, Ecosystems \& Environment, 96, 141-146.

Hoitink, H. A. J., \& Boehm, M. J. (1999). Biocontrol within the context of soil microbial communities: a substrate-dependent phenomenon. Annual Review of Phytopathology, 37, 427446.

Hoitink, H. A. J., \& Fahy, P. C. (1986). Basis for the control of soilborne plant pathogens with composts. Annual Review of Phytopathology, 24, 93-114.

Hoitink, H. A. J., Herr, L. J., \& Schmitthenner, A. F. (1976). Survival of some plant pathogens during composting of hardwood tree bark. Phytopathology, 66, 1369-1372.

Hoitink, H. A. J., Stone, A. G., \& Grebus, M. E. (1996). Suppression of plant diseases by composts. In: M. De Bertoldi, P. Sequi, B. Lemmes \& T. Papi (Eds.), The Science of Composting (pp. 373-381). Blackie Academic \& Professional: Glasgow, UK.

International Seed Testing Association (ISTA), \& (2007). Bassersdorf, Switzerland, Annexe to Chapter 7: Seed Health Testing Methods. 
Katan, J. (1981). Solar heating (solarization) of soil for control of soilborne pests. Annual Review of Phytopathology, 19, 211-236.

Kowk, O. C. H., Fahy, P. C., Hoitink, A. J., \& Kuter, G. A. (1987). Interactions between bacteria and Trichoderma hamatum in suppression of Rhizoctonia damping-off in bark compost media. Phytopathology, 77, 1206-1211.

Kuter, G. A., \& Hoitink, H. A. J. (1985). Use of combinations of microbial antagonists to suppress Rhizoctonia and Phythium damping-off in compost-amended container media. Phytopathology, 75, 1344 (abstract).

Lopez-Real, J., \& Foster, M. (1985). Plant pathogen survival during the composting of agricultural organic wastes. HortScience, 20, 358-360.

Munnecke, D. E., Wilbur, W., \& Darley, E. F. (1976). Effect of heating or drying on Armillaria mellea or Trichoderma viride and the relation to survival of A. mellea in soil. Phytopathology, 66, 1363-1368.

Nelson, D. W., \& Sommers, L. E. (1982). Total carbon, organic carbon, and organic matter. In: A. L. Page, R. H. Miller \& D. R. Keeny (Eds.), Methods of Soil Analysis. Part 2. Chemical, Microbiological Properties, (2 ed., pp. 570-571). Agronomy, Monograph No. 9, SSSA: Madison, WI.

Nelson, P. E., \& Wilhelm, S. (1958). Thermal death range of Verticillium albo-atrum. Phytopathology, 48, 613-616.

Newton, W. (1931). The physiology of Rhizoctonia. Soc. Agr., 12, 178-182.

Pugliese, M., Liu, B. P., Gullino, M. L., \& Garibaldi, A. (2011). Microbial enrichment of compost with biological control agents to enhance suppressiveness to four soil-borne diseases in greenhouse. Journal for Plant Diseases and Plant Protection (JPDP), 2, 45-50.

Reiten, J., \& Salter, C. (2002). Compost tea for suppression of Xanthomonas in carrot production. . Online journal of Growing Solutions Incorporated,

Ringer, C. (1998). Bibliography on compost for disease suppression. from http://ncatark.uark.edu/ steved/compost-disease-biblio.html.

SAS Institute. (2000). SAS Institute SAS/GRAPH software (Version 9.0). Cary, NC.: SAS Institute.

Schaad, N. W. (1988). Laboratory guide for identification of plant pathogenic bacteria (2 ed.). APS Press: St. Paul, MN.

Schönfeld, J., Gelsomino, A., Overbeek, L. S., Gorissen, A., Smalla, K., \& Elsas, J. D. (2003). Effects of compost addition and simulated solarisation on the fate of Ralstonia solanacearum biovar 2 and indigenous bacteria in soil. FEMS Microbiology Ecology, 43, 6374. 
Shobha, S. V., \& Kale, R. D. (2008). Invitro studies on cotrol of sil-brne pant pthogens by erthworm Eudrilus Eugeniae exudates. Green Pages, < http://www.ecoweb.com/editorial/080106.html>.

Stephens, P. M., \& Davoren, C. W. (1997). Influence of the earthworms Aporrectodea trapezoides and A. rosea on the disease severity of Rhizoctonia solani on subterranean clover and ryegrass. Soil Biology and Biochemistry, 29, 511-516.

Stephens, P. M., Davoren, C. W., Ryder, M. H., Doube, B. M., \& Correll, R. L. (1994). Field evidence for reduced severity of Rhizoctonia bare-patch disease of wheat, due to the presence of the earthworms Aporrectodea rosea and Aporrectodea trapezoides. Soil Biology and Biochemistry, 26, 1495-1500.

Sterne, R. E., McCarver, T. H., \& Courtney, M. L. (1979). Survival of plant pathogens in composted cotton gin trash. Arkansas Farm Res, 28, 9-9.

Szczech, M., Rondomanski, W., Brzeski, M. W., Smolinska, U., \& Kotowski, J. F. (1993). Suppressive effect of a commercial earthworm compost on some root infecting pathogens of cabbage and tomato. Biological Agriculture and Horticulture, 10, 47-52.

Tuitert, G., Szczech, M., \& Bollen, G. J. (1998). Suppression of Rhizoctonia solani in potting mixtures amended with compost made from organic household waste. Phytopathology, 88, 764-773.

van Elsas, J. D., \& Postma, J. (2007). Suppression of soil-borne phytopathogens by compost. Waste Management Series, 8, 201-214.

Yardim, E. N., Arancon, N. Q., Edwards, C. A., Oliver, T. J., \& Byrne, R. J. (2006). Suppression of tomato hornworm (Manduca quinquemaculata) and cucumber beetles (Acalymma vittatum and Diabotrica undecimpunctata) populations and damage by vermicomposts. Pedobiologia, 50, 23-29.

Ylimäki, A., Toiviainen, A., Kallio, H., \& Tikanmäki, E. (1983). Survival of some plant pathogens during industrial-scale composting of wastes from a food processing plant. Annales Agriculturae Fenniae, 22, 77-85.

Yuen, G. Y., \& Raabe, R. D. (1984). Effects of small-scale aerobic composting on survival of some fungal plant pathogens. Plant Disease, 68, 134-136. 


\section{General discussions}

\subsection{Implications for using cotton residues for crop growth}

Sudan is the largest country in Africa with more than $60 \%$ of the area within the arid and semi-arid zone, which is characterized by low and erratic rainfall. The desert extends from north to south at an alarming rate, and about 13 states out of the 26 states of Sudan are affected by desertification, (Salih, 2007). Land degradation as a consequence of desertification is considered as one of the greatest environmental problems in the Sudan, especially when coupled with the increasing demand for feeding the rapidly growing population posing a great pressure on the existing arable lands. Previous studies pointed out that, agricultural residues can be effective in enhancing and improving soil health (Chen et al., 1992; Esse et al., 2001; Murwira et al., 1995). To support the efforts of local communities in restoring degraded ecosystems through the application of agrarian residues; the study investigated the possibility of using decomposed cotton residues as a component of plant growth media in parallel with nitrogen mineralization incubation experiment to see how crop can mirror the ability of applied materials in releasing nutrients.

The results of cotton residues' decomposition indicated that analyses of the compost and vermicompost have shown a broad variation in a number of chemical and physical parameters. However, $\mathrm{C}: \mathrm{N}$ ratio, electrical conductivity (EC) and mineral $\mathrm{N}$ were found to be taken as reliable parameters to reflect the progress in the decomposition process of materials in question.

With regard to nutrient uptake results showed that, $\mathrm{N}$ recovered by ryegrass was too low (> $80 \%$ of $\mathrm{N}$ was not utilized by the crop) however, there was an increase in crop biomass compared to the control (unamended pots); there appeared to be a complementary relationship between $\mathrm{N}$ and $\mathrm{P}$ (Harrington et al., 2001). The results of the $\mathrm{N}$ incubation experiment showed that application of compost and vermicompost for a period longer than three weeks before sowing subsequent crop, may subject $\mathrm{N}$ to losses. $\mathrm{N}$ results from $\mathrm{N}$ incubation experiment did not match that obtained from the pot experiment but gave general indications of $\mathrm{N}$ availability to ryegrass.

A phytotoxicity bioassay test was conducted before finished compost, and vermicompost were used for crop growth; germination indexes obtained for the final vermicompost $(>80 \%)$ are greater than the values advised for the mature compost $(>70 \%)$ while finished compost $(>50 \%)$ did not attain it, therefore, vermicompost could be considered as safe for soil 
applications while compost did show adverse effects on seed germination and may need more time to be processed.

Amendments differ in their composition affect crop differently, and their processing is obviously of great beneficial effects, which contributed to crop growth and soil productivity. Crop responses to the applied materials of this work, suggested that there is more to be learned through the use of cotton residues on farmland. There may be scope to maximize nutrient use and minimize potential losses by mixing various of organic materials; for instance, combination of cotton residues with the readily available $\mathrm{N}$ from different wastes or mineral fertilizers may increase both crop yield and soil quality.

\subsection{Implications for mitigating the phytopathogen (Bacterial blight)}

In the Sudan, considerable quantities of crops' residue are annually burnt in most of the irrigated farming systems specially cotton residues to prevent the spread of bacterial blight, which exacerbates up to $35 \%$ loss in the productivity. Therefore, it is important to look for alternatives. Part of the work attempted to investigate the efficacy of composting and vermicomposting in controlling cotton bacterial blight. The study presented tentative results of the ability of composting and vermicomposting to reduce the pathogen colony-forming units (CFU). Results of this work are in accordance with most of the reported works with different materials and pathogens (Chung et al., 1988; Edwards et al., 2006; Hoitink et al., 1996; Yuen \& Raabe, 1984).

\subsection{Recommendations}

The following recommendations are given based on the results and observations of the studies.

1. Composting and vermicomposting succeeded to mitigate the cotton bacterial blight's colony-forming units; however, vermicomposting is more efficient and both can be integrated with the biological control programs.

2. For agricultural purposes, 240 tons $\mathrm{ha}^{-1}$ of the finished compost and vermicompost can be applied.

3. Vermicomposting can substitute composting in terms of nutrients' availability, less odour, and more homogeneous finished material. 
Pre-experiments have been conducted in order to set simple procedures and tools, which suit local conditions, where farmers could adopt it with ease. However, the results from these experiments are not included in the thesis, nevertheless; one can recommend the following:

1. A simple composting can be performed with different organic wastes (animal wastes, city refuse, vegetables' scraps from surrounding markets and different crop residues) with heaping above the ground in the following way: a layer of grasses, and small shrubs is placed on the ground and compacted as a basement or a polythene sheet can be used if available. The waste material is spread on the basement over $2 \mathrm{~m}$ width and the length varies as required, covered with animal wastes and starter dose of urea can be spread to enhance decomposition during early stages. This layering should be made up to at least 2 $\mathrm{m}$ height. Interval turning to ensure aeration can manually be managed, and water can be added when necessary.

2. For vermicomposting, rearing of earthworms is necessary in order to get sufficient quantities. This can be done in a sheltered area where the soil is thoroughly mixed with farm yard manure or any other suitable organic waste and kept moist (Fig. 8.1); this area can also be used for fast growing vegetables and other crops. The process can be carried out in pits below the ground under shade where the organic wastes can be spread and layered on a polythene sheet or the bottom of the pit can be covered with a layered of tiles, husk or shrubs. Tanks over the ground can also be used where the tanks can be made up of different materials such as normal bricks, hollow bricks, asbestos sheets and locally available rocks. The tanks can be constructed with dimensions appropriate for operations (e.g. $1.5 \times 4.5 \times 0.9 \mathrm{~m}$ (width $\times$ length $\times$ height)). Another construction like cement rinks (e.g. $90 \mathrm{~cm}$ in diameter and $30 \mathrm{~cm}$ in height) if affordable is also suitable. After choosing the desired construction, spreading and layering the organic wastes, earthworms can be introduced after the materials are decomposed for some days (after the thermophilic stage). When the process is set up, the construction should be covered with a very fine plastic, wire mesh or gunny bag to avoid earthworm escape and to prevent birds from picking the earthworms. Water should be sprinkled when required to maintain adequate moisture and body temperature of the earthworms. When the vermicompost is ready, earthworms can manually be sorted and either inoculated into new wastes or returned to the rearing area. 


\subsection{Conclusions}

The study presented: (1) predictive relationship between nitrogen uptake and nitrogen mineralized from cotton residues, (2) the tentative results of the efficacy of composting and vermicomposting in mitigating phytopathogen may pave the way for wide application of both methods, (3) parameters that can be used to monitor organic residue decomposition. Such information is necessary for establishing the basic information for organic farming projects, for restoring degraded soils. The application of vermicomposting should be extended and indigenous knowledge of using earthworm for fish hunting should be redirected to organic wastes' management. So far, data on cotton residues' decomposition, the kind generated during this study, are lacking particularly in the Sudan, where degraded lands are common and strengthening efforts to restore soil productivity in the long term are crucially needed.

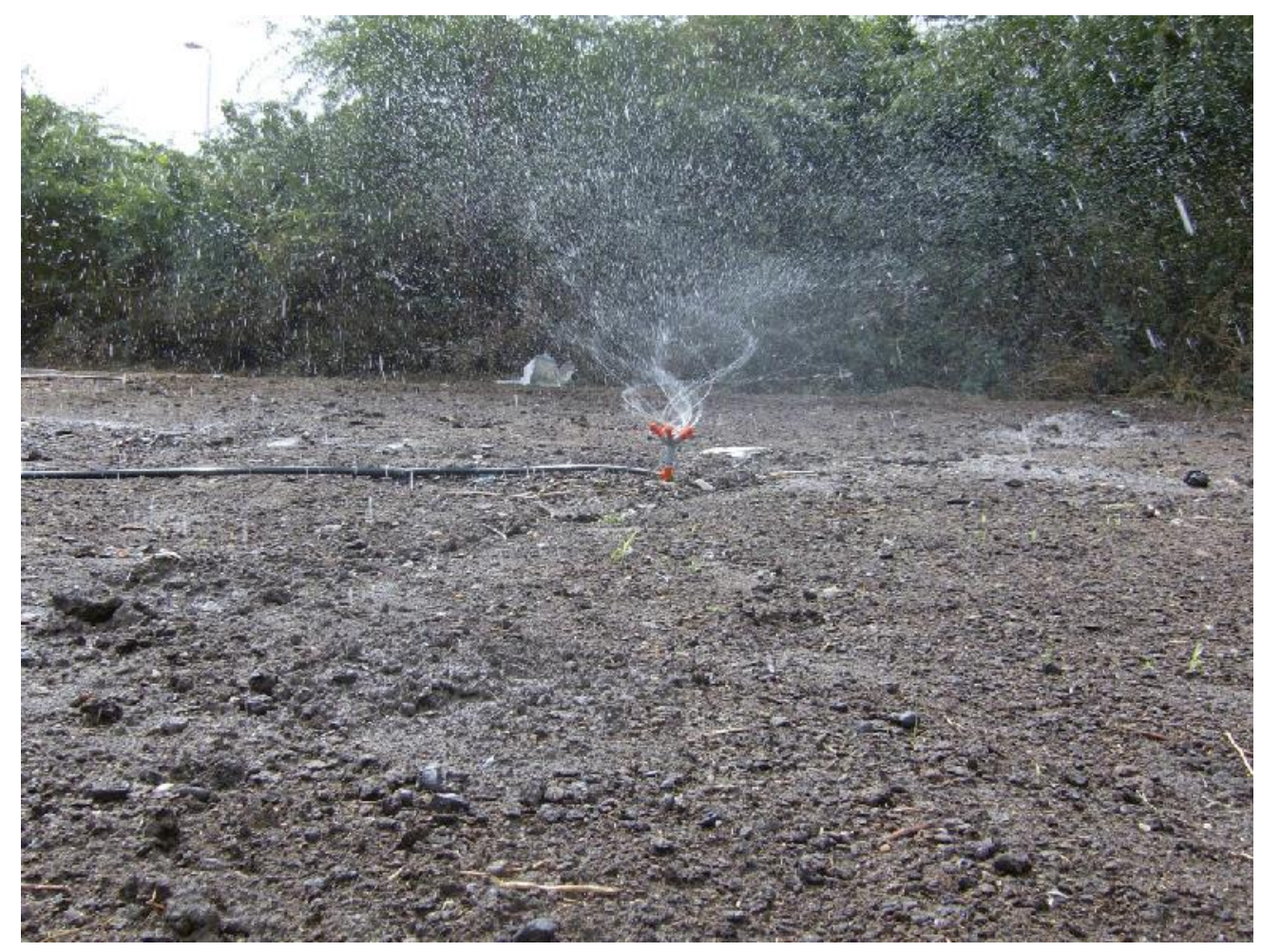

Fig. 8.1. A simple proposed procedure for rearing of earthworms. 


\section{5. $\underline{\text { References }}$}

Chen, Y., Inbar, Y., \& Hadar, Y. (1992). Composted residues reduce pest and pesticide use. BioCycle, 48-51.

Chung, Y. R., Hoitink, H. A. H., \& Lipps, P. E. (1988). Interactions between organic-matter decomposition level and soilborne disease severity. Agriculture, Ecosystems \& Environment, 24, 183-193.

Edwards, C. A., Arancon, N. Q., \& Greytak, S. (2006). Effects of vermcompost teas on plant growth and disease. BioCycle, 47, 28-31.

Esse, P. C., Buerkert, A., Hiernaux, P., \& Assa, A. (2001). Decomposition of and nutrient release from ruminant manure on acid sandy soils in the Sahelian zone of Niger, West Africa. Agriculture, Ecosystems \& Environment, 83, 55-63.

Harrington, R. A., Fownes, J. H., \& Vitousek, P. M. (2001). Production and resource use efficiencies in $\mathrm{N}$-and $\mathrm{P}$-limited tropical forests: a comparison of responses to long-term fertilization. Ecosystems, 4, 646-657.

Hoitink, H. A. J., Stone, A. G., \& Grebus, M. E. (1996). Suppression of plant diseases by composts. In: M. De Bertoldi, P. Sequi, B. Lemmes \& T. Papi (Eds.), The Science of Composting (pp. 373-381). Blackie Academic \& Professional: Glasgow, UK.

Murwira, K. H., Swift, M. J., \& Frost, P. G. H. (1995). Manure as a key resource in sustainable agriculture. In: J. M. Powell, S. Fernandez-Rivera, T. O. Williams \& C. Renard (Eds.), Livestock and Sustainable Nutrient Cycling in Mixed Farming Systems of Sub-Saharan Africa (pp. 131-148). International Livestock Centre for Africa (II C.A.): Addis Ababa, Ethiopia.

Salih, E. M. (2007). Action programmes for combating desertification UNESCO Chair of Desertification, University of Khartoum: Khartoum North, Sudan.

Yuen, G. Y., \& Raabe, R. D. (1984). Effects of small-scale aerobic composting on survival of some fungal plant pathogens. Plant Disease, 68, 134-136. 


\section{Acknowledgements}

First and foremost, praise and indebtedness to the "Almighty Allah" with Whose grace and blessings my wishes have been fulfilled and Who gave me the ability to complete this work. It is an honour to express my deepest gratitude and sincere appreciation to Prof. Dr. Kuzyakov and Prof. Dr. Claassen who took supervision of this work and for their help. Grateful thanks extended to Prof. Dr. Jorgensen for accepting to be a co-referee and for his suggestions and advice. I would like to express my deepest heartfelt gratitude and appreciation to Dr. Ahl for his endless patient, valuable comments, close supervision, financial support and great leadership throughout the entire period of my study. I am also indebted for his family for endless support during my stay.

Appreciations are due to all members and colleagues at the Division of Agricultural pedology for continuous help, family atmosphere and hospitality with profound reverence to Ingrid, Karin, Susan, and Dr. Peter. Special thanks also to the members of the Institute of Soil Science of Temperate Ecosystems, Faculty of Forestry. I highly appreciate the assistance of Dr. Sabine Heumann, Department of Soil Science - University of Hannover for conducting the nitrogen mineralization part. Many thanks extended to Dr. Mubarak Abdalla and Dr. Mudawi El Obied for their critical reading and corrections of some parts of the thesis.

A special debt for my family in the Sudan for supporting in every step and for their non-stop assistance; affection, love, enthusiasm, and time dedication from my family and from my wife Lana and cute kids Siddig and Suhaeeb, Many thanks to them for sacrificing their time during my the hard time I was passing through.

Completion of this work would have been impossible without the financial support provided by the Government of the Sudan through the University of Khartoum. The staff of the International Ph.D Program for Agricultural Sciences in Göttingen (IPAG) is gratefully acknowledged for their assistance and making the study period very comfort. I also express my sincere gratitude to all my friends and colleagues who are always willing to give their advice, assistance and moral support. 


\section{$\underline{\text { Dedication }}$}

To the soul of my bother Siddig

To my mother, father, brother and sisters

To my patient wife Lana, lovely and cute kids Siddig and Suhaeeb

I dedicate this work 


\section{Curriculum Vitae}

\section{PERSONAL DATA}

Name: Sulieman Hammad Nasser ALI

Permanent address:

Department of Soil and Environment Sciences

Faculty of Agriculture

University of Khartoum

Khartoum North, Postal Code 13314

Email: shnali59@yahoo.com

Born on 28.06.1975 in Kassala, Sudan

Marital status: Married (two sons)

\section{ACADEMIC QUALIFICATIONS:}

School certificate: Sudanese Secondary School Certificate (1992) Khor Omer National Modern, Khartoum, Sudan

B.Sc., Bachelor of Science (Agriculture), Class one (Honours) (2000) - Department of Soil Science - Faculty of Agriculture- University of Khartoum, Sudan

M.Sc., Master of Science (Desertification and Desert Cultivation Studies) (2004) -

Desertification and Desert Cultivation Institute - University of Khartoum, Sudan

Ph.D. student University of Göttingen-Germany

\section{PRIZES AWARDED:}

- University of Khartoum prize awarded for the best all round students passing out of Faculty of Agriculture, University of Khartoum, 2000

- Arab Organization for agricultural Development (AOAD) prize awarded for the best students in agriculture in the final year (2000)

\section{SKILLS:}

\section{Computer and Internet:}

- Diploma in computer maintenance and networking

- Statistical software (SAS, SPSS, Sigmaplot and Origin)

\section{TRAINING AND PAST RESPONSILITIES:}

- Lecturer (since 2005) (Department of Soil and Environment Sciences)

- Teaching assistant (2001- 2005) (Department of Soil and Environment Sciences).

- Teaching lab classes in the Desertification and Desert Cultivation Studies Institute, University of Khartoum

- Member of the Sudanese Environment Conservation Society (SECS)

- Member of the Sudanese Society for Combating Desertification (SACD)

- Cultural Secretary of Kassala Student Association (1998)

- Participation in the Arab Youth Students Creative Conference (Scientific paperSudan).

- Head of Kassala Student Association

- General Secretary of Kattala Student Association in the Universities and Higher Institutions 
- Member of the Sudan Village Concept Project (SVCP) II (IMISO- WHO) (1998 1999).

- Financial Secretary of the Sudanese Society for Combating Desertification (SACD)

- Contributor in many land evaluation and mapping field works in the country

- General Secretary of Kalk Voluntary Organization (K.V.O)

\section{Membership:}

- Soil Science Society of America

- American Society of Agronomy

- Crop Science Society of America

- The Sudanese Environment Conservation Society (SECS)

- The Sudanese Society for Combating Desertification (SACD)

\section{WORKSHOPS:}

- World Food System- A contribution from Europe. Tropentag. 14-16th Septembre 2010. ETH- Zurich.

- Biophysical and Socio-economic Frame Conditions for the Sustainable Management of Natural Resources. Tropentag. 6-8th October 2009. University of Hamburg, Germany.

- Improving Sustainability in Organic and Low Input Food Production Systems., The Research Institute of Organic Agriculture FiBL in cooperation with the University of Hohenheim. March 20-23, 2007.

- Stabile Isotope in the Soil (Stabile Isotope in der Bodenkunde, DBG). September 4 $-5,2006$. University of Göttingen - Germany.

- Prosperity and Poverty in a Globalised World- Challenges for Agricultural Research. Tropentag. 11-13th October 2006. University of Bonn, Germany

- Upscaling Soil Organisms and Soil Ecological Processes up to the Landscale. February 23-24, 2006. University of Vechta, Germany.

- Desertification and Natural Resources Deterioration in Southern Sudan. 29 August 2004. ElSharqa Conf. Hall. Khartoum, Sudan. (Local workshop).

- The Use of Space Technology. MOST, NCR- RSA, UNOOSA, and ESA. 4-8 April 2004. The Ribat International Conf. Hall. Khartoum, Sudan. (Regional workshop).

- Desertification and Media. 8 June 2003. Faculty of Agriculture, University of Khartoum. Abu Gidiri Hall. Khartoum, Sudan. (Local workshop).

- The Enlightenment of Citizens with the Desertification Hazards. 1st. June 2003. ElSharqa Conf. Hall. Khartoum, Sudan. (Local workshop).

- Diversified Fertilization For Yield Promotion in Sudan. (Fertilizer Workshop) (DAN ASIDCO - Sudan and Fertiva, Germany in corporation with the Agricultural Research Corporation (ARC). Friendship Hall. 26 May 2001. Khartoum, Sudan. 